\title{
A IDENTIDADE DO PRESO E AS LEIS DO CÁRCERE
}

Dissertação apresentada à Banca Examinadora da Faculdade de Direito da Universidade de São Paulo, como exigência parcial para obtenção do título de Mestre (área de Concentração Direito Penal, Medicina Forense e Criminologia), sob a orientação do Prof. Dr. Alvino Augusto de Sá.

Faculdade de Direito da Universidade de São Paulo

São Paulo - 2008 


\section{A IDENTIDADE DO PRESO \\ E AS LEIS DO CÁRCERE}

ANA GABRIELA MENDES BRAGA

DATA

BANCA EXAMINADORA

$1^{\circ}$ Examinador

Orientador Prof. Dr. Alvino Augusto de Sá

$2^{\circ}$ Examinador(a)

$3^{\circ}$ Examinador(a) 
"Durante todos esses anos, o homem observa o porteiro quase sem interrupção. Esquece os outros porteiros e este primeiro parece-lhe o único obstáculo para a entrada na lei. Nos primeiros anos, amaldiçoa em voz alta o acaso infeliz; mais tarde, quando envelhece, apenas resmunga consigo mesmo. Torna-se infantil, e uma vez que, por estudar o porteiro anos a fio, ficou conhecendo até as pulgas da sua gola de pele, pede a estas que o ajudem a fazê-lo mudar de opinião”.

(Kafka, Diante da Lei)

"Quem pode ser libertado enquanto estiver aprisionando alguém? O carcereiro não é livre, pois está preso junto ao seu prisioneiro. Ele precisa garantir que o outro não escape $e$ assim passa o tempo vigiando. As barras que limitam o prisioneiro vêm a ser o mundo em que vive o seu carcereiro junto com ele. E o caminho da liberdade para ambos depende da liberdade dele.” 


\section{AGRADECIMENTOS}

Agradeço ao meu orientador, Alvino Augusto de Sá, que além ter me guiado na construção dessa pesquisa, teve um papel essencial na minha entrada no mundo acadêmico, acompanhando com cuidado minhas primeiras aulas enquanto monitora de suas disciplinas e me colocando ao seu lado na idealização e realização de projetos que possibilitaram a abertura de novos espaços de reflexão e aplicação da Criminologia.

A Sérgio Salomão Shecaira, por ter despertado meu interesse pela Criminologia ainda na Graduação, e seguir arriscando novos olhares sobre as Ciências Penais. Suas colocações na banca de qualificação contribuíram para que eu apurasse minha análise da teoria criminológica e da própria realidade prisional.

A Fernando Salla, pelas pontuações precisas feitas no exame de qualificação. Seu cuidado na leitura do texto e sua disponibilidade em compor a banca foram essenciais para minha tentativa de construção de um trabalho interdisciplinar.

A Ana Lúcia Pastore, por me introduzir ao universo fascinante da Antropologia e me guiar nas aproximações dessa ciência com o Direito. Professora de escuta interessada e fala doce, por quem guardo um carinho imenso.

A Antônio Chaves de Camargo (in memorian), pela insaciável busca por novos conhecimentos e pela vontade de transmiti-los.

A querida colega Maria Emília Nobre Bretan, que tornou-se uma grande companheira nesse longo percurso. Durante três anos estivemos na coordenação adjunta de muitos projetos, dividimos responsabilidades, compartilhamos nossas angústias e nos amparamos uma na outra. Sua presença nesse período trouxe reconforto ao exercício desse trabalho, muitas vezes tão solitário, que é a pesquisa.

Ao colega Adalton, por compartilharmos, durante alguns cafés, as angústias e os questionamentos advindos das nossas pesquisas.

Aos presos que participaram do Grupo de Dialógo Universidade-Cárcere-Comunidade (GDUCC), por permitirem que meu olhar da prisão fosse apurado pela realidade; mas principalmente, por me desafiarem a sustentar o discurso libertário na prática prisional, 
permitindo que eu encarasse meus medos e preconceitos na tentativa de um encontro verdadeiro.

Aos companheiros do GDUCC, pela coragem de vivenciar a reintegração social a partir de um caminho que está sendo definido pelo próprio caminhar.

A todos do Grupo de Estudos de Tema de Criminologia (Getcrim) pela construção conjunta de um espaço de debate e reflexão da Criminologia no âmbito da Faculdade de Direito.

Aos funcionários da Faculdade de Direito da Universidade de São Paulo. Em especial, a Dalva e Cris, secretárias do Depto de Direito Penal, Medicina Forense e Criminologia, que com seu trabalho e dedicação, organizam e materializam nossos projetos. A Fátima da Seção de Pós-Graduação, por tratar com atenção e cuidado das burocracias que tanto atormentam os alunos.

Ao IBCCRIM, por sua importância enquanto espaço de troca e vanguarda, que possibilitou que eu me aprofundasse no estudo das Ciências Criminais.

A CAPES, pelo auxílio concedido, que possibilitou meu mergulho no universo da pesquisa.

A Mariana, Denise, Anaí e Isabela, amigas de Graduação, cujas conversas à luz do sol no pátio desafiavam a frieza dos muros que nos cercavam. É o que ficou de mais precioso daqueles tempos.

Aos meus amigos arquianos, que elegi como família, cuja simples presença na minha vida é de um carinho e conforto sem tamanho, com eles estou sempre em casa.

A todos do Instituto Ser Humano que me lembram com doçura do que sou feita.

A minha irmã Adriana, que há muitos anos vêm trilhando comigo o caminho do coração, e que por minha sorte, optou também por trabalhar com os sistemas punitivos (ou contra eles). Sua coragem e ousadia me desafiam a seguir firme num terreno tão árduo como esse, e me lembram que as coisas podem ser vistas de outra forma.

Ao meu irmão Gabriel, que, com suas provocações sempre pertinentes, me desafia à profundidade. 
A Felício, que com sua presença sempre amorosa, trouxe leveza à minha vida (e à edição deste trabalho).

A minha mãe, Licinha, mulher guerreira e generosa, por sua capacidade excepcional em conciliar controle e liberdade. Sua proteção constante somada à profunda confiança em mim fez com que eu assumisse com liberdade e responsabilidade as minhas escolhas.

Ao meu pai, seu Braga, eterno professor, que desde pequena me convida a entrar no universo dos livros e da doçura, e sutilmente me influencia a trilhar caminhos antes percorridos por ele. 


\section{SUMÁRIO}

\section{Resumo/Abstract}

Introdução

\section{Primeira Parte: A IDENTIDADE DO PRESO}

Capítulo 1: Criminologia clínica e crítica: uma aproximação possível $\quad 7$

1.1. Clivagem paradigmática 7

1.2. Paradigma da reação social 10

1.3. Crime enquanto construção social 13

1.4. Crime, desvio e situação problemática:

$\begin{array}{ll}\text { a linguagem enquanto construtora de significados } & 15\end{array}$

1.5. Propostas para uma criminologia clínica e crítica 17

1.6. Criminologia Clínica em Zaffaroni: a clínica da vulnerabilidade 21

1.7. Tarefa da criminologia clínica e crítica 22

$\begin{array}{ll}\text { Capítulo 2: Identidade } & 27\end{array}$

2.1. Conceituação de identidade 28

2.2. Identidade enquanto representação de papéis 31

2.3. Identidade na prisão 34

2.4. Estigma $\quad 40$

Capítulo 3: Processo de prisionização e conformação identitária 43

3.1. Processo de prisionização 43

3.2. Poder repressor e desculturação 45

3.3. A função do cárcere na dinâmica social e na dinâmica interna da prisão $\quad 46$

3.4. Vulnerabilidade e identificação secundária 54

3.5. Ajustamentos do individuo em relação às regras institucionais 58

3.6. Relativização da totalidade das instituições prisionais

$\begin{array}{ll}\text { na contemporaneidade } & 61\end{array}$

3.7. Bom preso ou bom criminoso 66 


\section{Segunda Parte: AS LEIS DO CÁRCERE}

$\begin{array}{ll}\text { Capítulo 4: Arranjo do poder na prisão } & \mathbf{7 0}\end{array}$

4.1. Esclarecimentos iniciais $\quad 70$

4.2. Constituição da dinâmica no cárcere:

simbiose entre normas jurídicas, disciplina e leis da massa 72

4.3. Gerenciamento da dinâmica prisional:

$\begin{array}{ll}\text { a legitimação das práticas } & 78\end{array}$

4.4. Negociação do poder prisional $\quad 82$

4.5. Política penitenciária e facções criminosas 88

4.6. A lei e a ordem: soberania e disciplina 99

$\begin{array}{ll}\text { Capítulo 5: Ordem formal: direito penitenciário } & 106\end{array}$

5.1. Natureza do processo de execução 108

5.2. Competência Normativa 115

5.3. Garantias Constitucionais aplicadas à Execução Penal 118

5.4. Lei de Execução Penal 119

5.5. Secretaria de Administração Penitenciária de São Paulo 126

5.6. Regimento interno padrão dos estabelecimentos

prisionais do Estado de São Paulo 127

5.7. Lei dos Crimes Hediondos 133

5.8. Regime Disciplinar Diferenciado 136

5.9. O Regime Disciplinar Diferenciado e a criminologia do outro 142

Capítulo 6: Ordem informal: as leis da massa e as facções criminosas $\quad 147$

$\begin{array}{ll}\text { 6.1. Ordem informal } & 147\end{array}$

6.2. O indivíduo na organização 150

6.3. As facções: recorte do objeto 153

6.4. O impacto das facções na ordem prisional 157

6.5. As leis da massa 162

6.6. As regras das facções 166 
Capítulo 7: O preso e as facções criminosas

7.1. Resistência: um ponto fundamental para análise do poder

7.2. Funcionamento das facções criminosas

7.3. Hierarquia interna e papéis sociais

7.4. Líder das facções

7.5. Facções criminosas: um meio de afirmação identitária?

7.6. A autonomia ética como condição da subjetividade 


\title{
RESUMO
}

O presente estudo analisa como as demandas institucionais e as regras do cárcere afetam e conformam o indivíduo preso. O processo de prisionização implica na absorção de valores, costumes e normas próprias da cultura prisional; a apropriação das regras, dos códigos de linguagem e dos conhecimentos desse grupo social específico traz impactos à identidade do preso. A partir do conjunto de normas que regem o dia-a-dia prisional - que inclui aquelas produzidas pelo Estado (ordem formal), as elaboradas pelos próprios presos (ordem informal) e mesmo as disciplinas (enquanto poder normativo fundamental à manutenção dessas duas ordens) - pode-se compreender qual o tipo de individualidade essas regras pretendem produzir e as diferentes formas do indivíduo reagir a tais exigências institucionais.

Palavras chave: prisão - identidade - prisionização - direito penitenciário - facções criminosas

\begin{abstract}
This study examines how the institutional demands and the rules of the jail affect and conform the inmate man. The process of prisonization implies the absorption of values, habits and standards proper of prison culture; the appropriation of the norms, codes of language and knowledge of this specific social group brings impacts to the identity of the prisoner. From the set of rules governing the day-to-day prison - including those produced by the State (formal order), as elaborated by the prisoners (informal order) and even the disciplines (as normative power essential to the maintenance of these two orders) - one can understand what kind of individuality these rules aim to produce and the different ways of the individual reacting to such institutional requirements.
\end{abstract}

Keywords: prison - identity - prisonization - penitentiary law - criminal organizations 


\section{INTRODUCÃO}

O presente estudo tem como objeto a relação entre identidade do preso e leis do cárcere. Muito já se produziu acerca da "falência da prisão" e do fracasso das finalidades da pena privativa de liberdade. Não partirei destes pressupostos, por entender que são justamente as características estruturais do sistema penal que dificultam a realização dos fins oficialmente atribuídos a ele.

Sob a perspectiva foucaultiana, a falência da prisão coincide com seu próprio nascimento no início do século XIX, quando se verificou que a pena restritiva de liberdade, ao contrário de reduzir a delinqüência, seria produtora da mesma, assim como da própria reincidência. Porém, ao aparentemente fracassar, a prisão não erra seu objetivo (Foucault, 2002, p.230), pois ainda que no exercício do poder repressor sua eficácia venha a ser contestada, a prisão continua reformando e produzindo individualidades, objetivando quais ilegalidades e quais transgressores conformarão a delinqüência, alcançando, desta forma, seus fins principais.

Desse modo, não se há de falar em crise do sistema já que, ainda que superada a "crise”, ele continuaria seletivo, estigmatizante e ineficaz, pois é próprio de sua configuração. A função da prisão está justamente em produzir e isolar a delinquêencia, seja diferenciando, selecionando, ocultando ou destacando certas ilegalidades em detrimento de outras.

Logo, para a presente análise, partirei de dois pressupostos: de que a real função do sistema penal foi e continua a ser muito bem executada; e de que o poder mais perigoso exercido no interior das prisões é o poder configurador, que molda e fixa a identidade do indivíduo a partir da disciplinarização de sua vida, e não o repressivo, que anula e exclui.

Esta pesquisa tem como objetivo geral tentar identificar como o indivíduo preso se relaciona com as normas do universo prisional e reage às exigências institucionais, ou seja, quais as formas de ajustamento identitário ${ }^{1}$ do indivíduo perante as regras prisionais. Para tanto,

\footnotetext{
${ }^{1}$ Denominarei “ajustamento” o modo como o individuo se relaciona com as regras institucionais, mesmo quando essa forma se aproxima mais do desajuste que do ajuste. De acordo com o Dicionário Houaiss da língua
} 
considerarei como regras prisionais tanto as normas formais do estabelecimento carcerário quanto as práticas informais consolidadas na dinâmica prisional.

São dois objetivos específicos. O primeiro consiste em estudar o impacto da ordem institucional sobre a identidade do indivíduo preso, analisando o processo de prisionização e as características estruturais do sistema penal, e constatando em que medida eles afetam e conformam a identidade do preso.

O segundo objetivo específico é compreender a estrutura normativa e organizacional da prisão a partir das regras que regem o mundo prisional. Para tanto, serão analisadas tanto as normas produzidas pelo Estado (ordem formal), como as elaboradas pelos próprios presos (ordem informal). Além das leis estatais e das leis da massa, será analisado o papel das disciplinas na organização do espaço prisional, enquanto poder normativo fundamental à manutenção dessas duas ordens.

Para facilitar nossa análise, a pesquisa será dividida em duas partes: uma que cuidará do processo de prisionização e suas conseqüências na identidade do preso; e outra, que mapeará o campo normativo do sistema prisional. Na primeira parte, composta pelos capítulos 2 e 3, buscarei contemplar o primeiro objetivo especifico; e na segunda, formada pelos capítulos 4, 5 e 6, procurarei atingir o segundo objetivo específico. ${ }^{2}$

Ao relacionar a realidade prisional, o indivíduo e as ordens que regem a prisão, a pesquisa pode vir a trazer uma contribuição ao debate acadêmico. Sobretudo por propor uma abordagem diferente da questão prisional: compreender o universo do indivíduo preso a partir das normas que regem o cárcere, tanto daquelas produzidas oficialmente quantos das práticas constituídas na dinâmica da instituição.

portuguesa (Rio de Janeiro, Objetiva, 2001): Ajuste "2. atitude de integração harmônica em um contexto, adaptação, amoldamento; 3. estabelecimento de um pacto, trato, acordo, convenção". Desajustar “ romper com que se havia acertado ou combinado, desfazer o ajuste (contrato, acordo, etc...); desunir (em) -se (peças etc.) que estavam ligadas ou justapostas; fazer ficar fora da justa medida ou do graus certo de ajustamento"; afrouxar(-se); soltar(-se); tornar-se mal ajustado ao seu meio social”

${ }^{2}$ Mais adiante, ainda na presente introdução, farei a descrição especifica dos capítulos que irão compor esta dissertação. 
Ademais por tratar de uma questão emergente que amedronta e fascina o país: o sistema prisional brasileiro e as demonstrações de força das facções criminosas ${ }^{3}$. A presença delas nos presídios brasileiros mudou por completo a configuração do espaço prisional, assim como as relações em seu interior. Logo, é essencial que essa realidade emergente seja considerada em um estudo que tem por objeto o preso e as questões penitenciárias contemporâneas.

Adentrar no mundo prisional, apreendendo um pouco de sua dinâmica a partir das regras que a constituem, e se aproximar do universo do indivíduo preso, analisando como ele se insere nesse mundo e reage às suas cobranças: esses são os desafios que tentarei superar no decorrer desta dissertação.

Além desta Introdução e das Notas Conclusivas, a presente dissertação está estruturada em 7 capítulos, da seguinte forma:

O Capítulo 1 surgiu da necessidade de situar essa pesquisa no âmbito da criminologia, compreendendo de que forma a perspectiva clínica, que sempre esteve intimamente ligada ao paradigma etiológico, poderia ser trabalhada à luz de outro paradigma. Para tanto, me debruçarei nos dois paradigmas constituintes do saber criminológico: paradigma etiológico e da reação social, de forma a contextualizar a mudança na abordagem criminológica ocorrida no final dos anos 60, assim como suas conseqüências para a perspectiva clínica. Trabalharei ainda com as propostas de construção de uma nova criminologia clínica, distante de sua origem positivista, elaborada por alguns criminólogos contemporâneos, quais sejam: Eugenio Raúl Zaffaroni (Universidade de Bueno Aires), Álvaro Pires (Universidade de Otawa), Cristhian

\footnotetext{
${ }^{3}$ Em meados de junho/2005 a rebelião na Penitenciária 1 de Presidente Venceslau, ocupada majoritariamente por integrantes do Primeiro Comando da Capital (PCC), provocou a morte de 5 pessoas que tiveram suas cabeças cortadas e exibidas como troféu. Nos primeiros dias de novembro/2003 foram mais de 30 ataques noticiados contra a polícia atribuídos ao PCC: esses ataques seriam uma forma de pressionar o governo contra o RDD (Regime Disciplinar Diferenciado) adotado nos presídios de Presidente Bernardes, Avaré e Taubaté, onde estavam os líderes da facção. Em 2001, uma mega rebelião eclodiu em 29 presídios simultaneamente. E, mais recentemente, em maio de 2006, além das rebeliões em mais da metade dos estabelecimentos prisionais do Estado, ataques (atribuídos ao PCC) realizados contra delegacias, bancos, fóruns, ônibus e policiais causaram pânico na cidade de São Paulo.
} 
Debuyst e François Digneffe (Universidade Católica de Louvain), e ainda, Alvino Augusto de Sá (Universidade de São Paulo).

O presente trabalho tem como base a "linha teórica crítica" ${ }^{4}$, que substituiu o tradicional paradigma etiológico da criminologia pelo paradigma da reação social, deslocando o foco da análise criminológica do autor para as agências do sistema penal. Porém, sem me afastar dessa perspectiva crítica, pretendo realizar uma abordagem clínica, com foco no indivíduo, porém não com o fim de buscar nele as causas da delinqüência tal como o fazia a criminologia tradicional de abordagem bio-psicológica, mas sim de entender quais as implicações do sistema punitivo no universo individual e quais são as formas do indivíduo se relacionar com as normas formais e informais do universo prisional.

Ainda no inicio dos meus estudos, vislumbrei a necessidade de me posicionar em relação a algumas questões relativas à identidade, por isso no Capítulo 2 me arriscarei pela área da psicologia social com o objetivo de explicitar a concepção de identidade na qual esta pesquisa se baseia, assim como evidenciar os processos que a constituem e a sua dinâmica dentro do universo prisional. Logo, além de uma tentativa de conceituação de identidade a partir da teoria de Antonio da Costa Ciampa e Silvia T. Lane (Pontifícia Universidade Católica de São Paulo), abordarei, nesse capítulo, as implicações do encarceramento na dinâmica identitária, a partir da teoria da representação de papéis sociais e da construção da identidade estigmatizada de Erving Goffman (1985 e 1988, respectivamente).

No Capítulo 3 será discutida a relação entre processo de prisionização e conformação identitária, de forma a atender o primeiro dos objetivos específicos. A seletividade e estigmatização são características estruturais do sistema penal. Quanto mais vulnerável o

\footnotetext{
${ }^{4}$ Utilizo aqui o termo critica em sentido amplo, o qual se aproximaria do que Lola Anyar de Castro (2005, p.66) denominou criminologia da libertação em oposição à criminologia da repressão. A criminologia da libertação abrange tanto a perspectiva do materialismo histórico quanto a construcionista. Apesar de não me filiar epistemologicamente ao materialismo histórico, não descartareis sua análise. Da mesma forma, ao seguir a perspectiva construtivista, tentarei me afastar do relativismo que lhe é próprio em direção ao entendimento de que o estudo da reação social e das conseqüências no individuo, a partir do processo de interação, não pode se afastar de questões como o poder e a posição que o indivíduo ocupa na configuração social. Nesse mesmo sentido cabe mencionar a divisão feita por Dias e Andrade (1997, p.255) e Shecaira (2004, p.133) entre teorias do consenso e do conflito, que abordarei mais adiante neste trabalho.
} 
indivíduo maior a chance de ser selecionado pelo sistema de controle, e conseqüentemente, sofrer as mazelas do processo de prisionização, que consiste dentre outras coisas em graves violações às suas concepções identitárias. O processo de prisionização ocasiona mudanças profundas na forma do preso ver a si próprio e ser visto pelos outros. A intensidade com que o individuo internalizará a cultura prisional e a forma como ele se relacionará com as regras prisionais, irão determinar o tipo de ajuste que o indivíduo terá em relação às exigências formais e informais da instituição.

No Capítulo 4, farei uma análise de como se dá o arranjo de poder na prisão. Abordarei a relação entre os sistemas normativos que regem o cárcere (normas jurídicas e leis da massa) e o funcionamento dos mecanismos disciplinares. A ação dos mecanismos disciplinares permeia tanto ordem instituída pelo Estado (ordem formal) quanto àquela estabelecida pelos próprios presos (ordem informal) e se constitui enquanto poder normativo fundamental à manutenção dessas duas ordens. Como o poder estatal não consegue controlar sozinho a dinâmica da prisão, o cotidiano prisional é negociado com os presos. Esta postura de gerenciamento do cárcere por parte do Estado contribui para que práticas (muitas vezes ilegais) regulem sua dinâmica interna e para que os presos ampliem sua influência na ordem prisional. Quando há um desarranjo no equilíbrio de poder estabelecido entre o Estado e os presos, se instauram as crises no sistema penitenciário, as quais durarão até que um novo arranjo de poder se estabeleça.

No Capítulo 5 analisarei os diplomas legais que regem a ordem jurídica da prisão, conformando assim o chamado direito penitenciário. Nesse capítulo discutirei a natureza do processo de execução penal, a atribuição de competência para legislar sobre a matéria, e, principalmente, as normas jurídicas que regulamentam a execução da pena, dentre as quais as Garantias Constitucionais, a Lei de Execução Penal, a Lei dos Crimes Hediondos, tal como as Resoluções da Secretaria de Administração Penitenciária de São Paulo e Regimento interno padrão dos estabelecimentos prisionais do Estado de São Paulo. Ao final, me centrarei na análise do Regime Disciplinar Diferenciado e suas conseqüências. 
No Capítulo 6 focarei o estudo na ordem informal da prisão. Primeiro analisando a organização informal dos presos e como o indivíduo se relaciona com ela; para em seguida, abordar o sistema normativo que regula essa ordem e conforma as leis da massa. Dentro desta perspectiva, analisarei ainda o impacto das facções criminosas e de suas regras na dinâmica prisional e na organização informal da prisão.

Ao final, no Capítulo 7 me centrarei em como o indivíduo se insere nas facções criminosas. Discutirei em que medida as facções seriam reprodutoras da seletividade do sistema de controle e das relações de poder da sociedade em geral e contribuem para a preservação da identidade de seus membros, analisando-as à luz do conceito de ajustamento secundário de Goffman ${ }^{5}$.

No decorrer da dissertação ilustrarei a relação identidade x normas do universo prisional com algumas falas dos presos, obtidas direta e indiretamente ${ }^{6}$, buscando compreender como o indivíduo se relaciona com a ordem formal e informal da prisão e quais as conseqüências para a sua identidade. Essa ilustração é uma tímida tentativa de possibilitar que o discurso dos presos venha à tona:

“E quando os prisioneiros se puseram a falar, eles próprios tinham uma teoria da prisão, da penalidade, da justiça. Essa espécie de discurso contra o poder, esse contra-discurso sustentado pelos prisioneiros ou por aqueles a quem se chamam delinqüentes, é isso o que conta, e não uma teoria sobre a delinqüência”.

(Foucault, 2006, p.40)

\footnotetext{
${ }^{5}$ Para Goffman (1974) os internos ao contrariarem a ordem institucional (ajustamento secundário) consolidam uma forma de abrigo para o eu: um meio de negar o papel que a instituição lhe impinge e neutralizar o processo de prisionização.

${ }^{6}$ Direta a partir da experiência do Grupo de Diálogo Universidade-Cárcere-Comunidade (GDUCC), criado no $2^{\circ}$ semestre de 2006, no âmbito da Faculdade de Direito da USP (FDUSP), dentro do Departamento de Direito Penal, Medicina Forense e Criminologia (DPM), sob a coordenação do Prof. Dr. Alvino Augusto de Sá e com a coordenação adjunta minha e da mestranda Maria Emília Accioli Bretan, que realiza um trabalho em uma penitenciária do Estado de São Paulo desde o $2^{\circ}$ semestre de 2006. E, indiretamente por meio das falas dos presos em biografias e outros documentos como os relatórios das Comissões Parlamentares de Inquérito.
} 


\section{CAPÍTULO 1}

\section{CRIMINOLOGIA CLÍNICA E CRÍTICA: UMA APROXIMAÇÃO POSSÍVEL}

"A criminologia é algo mais do que o estudo do delinqüente, da delinqüência e do delito... A criminologia é também o estudo de uma série de processos que são marginais aos códigos penais. Todos aqueles fenômenos comportamentais e psicossociais que estão no umbral do fenômeno jurídico..."

(CASTRO, 1983, p. 53)

\subsection{Clivagem paradigmática}

Até o inicio dos anos 60 a criminologia era pautada exclusivamente pelo paradigma etiológico. Essa criminologia, chamada tradicional ou positivista, tinha como objeto por excelência o homem delinqüente e como objetivo principal buscar nesse indivíduo características que explicassem a delinqüência, para assim poder diagnosticá-lo e tratá-lo.

Tal abordagem vinha sendo feita desde o inicio da criminologia, ainda no principio do século XX, pelos positivistas italianos Lombroso, Ferri e Garófalo, empenhados no projeto de construção de uma ciência causal-explicativa da criminalidade a partir do método indutivo, buscando a superação dos pressupostos sustentados pela escola clássica do direito penal.

O crime era visto pela escola clássica exclusivamente como um ente jurídico e o homem como um ser abstrato, que não interessava à ciência penal. A grande contribuição da escola positivista foi passar a conceber o crime enquanto um fato naturalístico e voltar o olhar da ciência penal para o homem concreto. Enquanto a teoria clássica pautada pela ideologia liberal centrava-se no livre arbítrio e concebia o delito como manifestação da vontade livre do agente, os positivistas, influenciados pelas ciências naturais, defendiam a incidência de um determinismo bio-psico-social, o qual justificaria a existência de duas das principais categorias positivistas: o delito natural e o delinqüente nato. 
Essa corrente de pensamento pressupunha que existissem diferenças ontológicas entre o individuo não criminoso ("normal”) e o criminoso (“anormal”), assim como entre a ação delituosa e não delituosa. A sua tarefa principal seria estudar a "personalidade criminal” para buscar a "falha" que levou o individuo a delinqüir. A lei penal assumia então um caráter meramente declarativo, pois somente reconheceria a existência ou não do crime, que já existia na realidade como tal.

A partir do inicio dos anos 60, influenciada pelas orientações construtivistas da sociologia americana, tais como o interacionismo simbólico $^{7}$ e a etnometodologia ${ }^{8}$, observa-se o surgimento de um novo paradigma dentro da criminologia: o paradigma da reação social. A partir dessa ruptura ${ }^{9}$, o objeto por excelência da criminologia deixa de ser o homem e passa a ser o sistema de controle. Os criminólogos procurarão entender o próprio processo de criminalização: quem constrói a realidade criminal, de que forma o faz e a quem o sistema penal visa atingir.

Um paradigma ${ }^{10}$ não só determina os métodos, valores e crenças de uma determinada comunidade científica, mas também os problemas que deve enfrentar e seu objeto de estudo; ele é constitutivo da atividade cientifica:

${ }^{7}$ Corrente da psicologia social e sócio-lingüística pela qual individuo e sociedade se relacionam a partir de uma relação dialética entre a estrutura social e a pessoa, constituindo assim um processo social, que constrói e reconstrói significações e a própria realidade. Esse processo de interação é intermediado pela linguagem, que como sistema de significados compartilhados (símbolos) ocupa um papel central na interação. O discurso consiste em uma prática dialógica, que produz sentidos. Um dos seus principais expoentes foi George Mead (1863-1931). Tal corrente influenciou vários autores importantes, tais como os teóricos do labeling approach Howard Becker e Erving Goffman.

8 “Um dos objetivos fundamentais da etonometodologia é penetrar nas situações normais de interação de modo a descobrir as regras e os rituais que os participantes assumem como garantidos" (Denzin apud Dias e Andrade, 1997, P.54)

${ }^{9}$ Tomas Kunh mudou o rumo da filosofia da ciência com o consagrado ensaio A Estrutura das Revoluções Cientificas, publicado pela primeira vez em 1962, no qual propõe que a evolução da ciência não se dá por continuidade, como até então acreditava-se, mas por rupturas. Por essa perspectiva, uma revolução cientifica ocorre a partir de uma mudança paradigmática, a qual é essencial para a evolução e maturação de uma ciência.

${ }^{10}$ Um paradigma consiste em uma forma própria de ver e analisar o mundo, nos dizeres de Kunh "um paradigma é aquilo que os membros de uma comunidade cientifica partilham e, inversamente, uma comunidade científica consiste em homens que partilham um paradigma” (Kunh, 2005, p.221) 


\begin{abstract}
“Ao aprender um paradigma, o cientista adquire ao mesmo tempo uma teoria, métodos e padrões científicos... Por isso, quando os paradigmas mudam, ocorrem alterações significativas nos critérios que determinam a legitimidade tanto dos problemas quanto das propostas”.
\end{abstract}

(Kuhn, 2005, p.144)

Com o advento do paradigma da reação social, tanto as questões quanto as soluções para o problema da criminalidade apresentadas pela criminologia baseada no paradigma etiológico perderam espaço e legitimidade ${ }^{11}$. A partir da consolidação desse novo paradigma, o estudo das causas do crime deixa de constituir um objeto legitimo para a criminologia, assim como o tratamento ou ressocialização passam a ser questionados enquanto fins da execução penal.

Com a mudança de foco do individuo para o sistema de controle, qualquer abordagem clínica passa a ser refutada, primeiramente por a associarem ao antigo paradigma etiológico difundido pelos positivistas ${ }^{12}$, e depois por seu objeto (indivíduo) ter sido completamente afastado do âmbito da criminologia sob essa perspectiva. Dessa forma, com o surgimento dessa "nova criminologia”, as questões que envolviam o homem enquanto ser concreto, singular, foram deixadas de lado. ${ }^{13}$

\footnotetext{
${ }^{11}$ Segundo Marteau (1997, p. 101) além do deslocamento do objeto de estudo, a perspectiva da reação social mudou o próprio fundamento analítico da criminologia: das categorias biológicas para as categorias lingüísticas.

${ }^{12}$ Segundo Lola Anyar de Castro: "Tanto a Criminologia Clínica quanto a Geral são escolas de cunho positivistas". A autora entende por criminologia geral uma criminologia "de síntese”, que a partir do apanhado de algumas ciências que trabalham a criminalidade "vai tentar estabelecer leis gerais de explicação da delinqüência como fenômeno social”. (Castro, 1983, p. 59)

${ }^{13}$ Na visão de Álvaro Pires, o pensamento critico, ao rejeitar o estudo do individuo a partir de um enfoque psicológico, foi condenado a se auto-definir como contrário à interdisciplinaridade, uma vez que a abertura a psicologia é vista como um “passo na direção errada” (Pires, 1992, p.5).
} 


\subsection{Paradigma da reação social ${ }^{14}$}

O paradigma da reação social foi inaugurado na década de 60 pela teoria interacionista do labelling approach, pela qual o crime e o criminoso não tinham existência autônoma, mas eram produtos de um processo de etiquetamento conduzido pelo sistema de controle, o qual ocorria no curso da interação social. Foi o americano Howard Becker e o canadense Erving Goffman a partir das respectivas obras Outsiders e Estigma (ambas publicadas em 1963) os primeiros a interpretar o desvio a partir do interacionismo.

Segundo Dias e Andrade (1997, p. 43), a teoria do labelling approach causou uma ruptura metodológica e epistemológica ao abandonar o paradigma etiológico-determinista. Metodológica por substituir o reducionismo da lógica causal-naturalista pela complexidade da dialética; e epistemológica por modificar o próprio objeto de estudo da criminologia da açãocomportamento para a reação-sistema de controle, assim como a maneira de interpretá-lo, do estudo das causas do crime para o estudo do processo de criminalização.

Ao substituir o pressuposto de que a sociedade é um todo homogêneo (modelo do consenso) pelo de que a sociedade é a expressão de um conflito (modelo do conflito) ${ }^{15}$, essa teoria pôs em xeque a concepção do crime enquanto uma realidade desvalorada socialmente. Passa a concebê-lo enquanto uma construção, produto da dominação de um grupo sobre outro, do grupo que cria as regras sobre outro mais vulnerável. Dez anos mais tarde, a criminologia

\footnotetext{
${ }^{14}$ Chamado também de paradigma do controle social se opõe ao paradigma etiológico (ou da passagem ao ato), ou ainda na denominação criada por Álvaro Pires paradigma de definição social (reação social) em oposição ao paradigma do fato social bruto (etiológico) (Pires, 1993, p.130).

${ }^{15}$ A primeira perspectiva construída a partir de um "modelo funcional” estaria ligada ao trabalho de Émile Durkheim, enquanto a segunda - “modelo dialético” à teoria de Karl Marx (Chambliss, 1980, p.203). Acerca dessas duas concepções de sociedade e suas conseqüências na formulação de teorias no âmbito da criminologia, não podíamos deixar de nos remeter ao belo trabalho do professor Sérgio Salomão Shecaira no qual ele propõe a divisão das teorias macrossociológicas em dois grandes grupos: teorias do consenso (que incluiria a Escola de Chicago, teoria da associação diferencial, teoria da anomia e teoria da subcultura delinqüente) e teorias do conflito que abrangeriam a teoria interacionista e a crítica; segundo o autor "para as perspectivas do consenso a finalidade social é atingida quando há um perfeito funcionamento das instituições e os indivíduos compartilham as regras vigentes e dominantes. Para teoria do conflito a coesão e a ordem são fundadas na força e na coerção, na dominação por alguns e sujeição por outros (Shecaira, 2004, p. 134) .
} 
crítica, de inspiração marxista, iria entender este processo como expressão da dominação de uma classe detentora do poder econômico sobre a outra.

A partir da negação da existência de uma realidade criminal autônoma, a criminalidade passa a ser reconhecida enquanto um fenômeno normativo, ou seja, a delinqüência é criada pela lei. Dessa forma, uma visão causal-naturalista (positivista) não daria conta de explicar o crime, já que não se trata de uma realidade ontológica, existente na natureza, regida pelas leis de causalidade, mas de uma realidade dinâmica, fruto das normas, construída por determinadas convenções, a qual exige uma outra abordagem na sua apreensão (Andrade, 2001 e Santos, 1979).

O que interessa a esta criminologia é, a partir da análise do próprio sistema punitivo e dos agentes de controle social, entender como é definido o crime e a quem cabe essa definição. Daí a denominação criminologia da reação social, uma vez que seu foco deixa de ser a ação criminosa e passa a ser a reação do sistema de controle em relação à conduta desviada.

Essa mudança paradigmática deu origem a uma "nova criminologia” ${ }^{16}$ voltada para o sistema de controle. Baratta ressalta dois deslocamentos na transição da criminologia positivista à criminologia de enfoque crítico: “do enfoque teórico do autor para as condições objetivas, estruturais e funcionais que estão na origem do fenômeno do desvio”; e, ainda, “do interesse cognitivo das causas do desvio criminal para os mecanismos sociais e institucionais através dos quais é construída a realidade social” (2002, p.160).

\footnotetext{
${ }^{16}$ A denominação nova criminologia faz referencia à criminologia de orientação marxista, essa denominação consagrou-se a partir da obra The New Criminology: for a social theory of deviance, publicada em primeira edição na Inglaterra, em 1973, por Ian Taylor, Paul Walton e Jack Young, os quais foram responsáveis por inaugurar a discussão quanto aos processos de criminalização, tecendo criticas a partir de uma perspectiva materialista- histórica `a teoria do labelling approach; das quais as duas principais eram quanto ao determinismo e a concepção desviado enquanto um sujeito passivo, a medida em que o crime não é uma opção consciente, mas produto da estrutura de controle; e, ainda, somente explicar criminalização secundária, e não o desvio primário que para os adeptos dessa "nova criminologia" seria ocasionada por fatores estruturais da sociedade capitalista. São utilizados também os nomes criminologia critica ou radical para a criminologia que se baseia no método marxista.
} 
A partir desses deslocamentos percebe-se uma cisão no saber criminológico em relação ao seu objeto de estudo, com a coexistência de uma criminologia pautada no antigo paradigma etiológico, que mantém como objeto de estudo o homem (a ação); com essa nova criminologia centrada no sistema de controle (na reação social).

Com base no objeto a ser investigado, Castro (1983, p.60) divide as tendências da criminologia em dois grupos ${ }^{17}$ : criminologia da passagem ao ato e criminologia da reação social; enquanto a primeira teria como objeto de estudo o homem e a sociedade, com interesse no delinqüente e no por que da ação delituosa, a segunda se concentraria na reação da sociedade às condutas desviadas, englobando tanto a criminologia interacionista quanto a critica.

Contudo, é necessário demarcar a diferença epistemológica existente entre a criminologia interacionista e a crítica. Enquanto a primeira se constrói a partir da filosofia construcionista, a segunda é pautada pelo materialismo histórico. Apesar da criminologia critica ter absorvido um pouco do construcionismo ao pressupor que a delinqüência é criada pela lei e que a realidade, assim como a ciência, são construções sociais, ela difere à medida que a filosofia critica constitui uma práxis, que busca a radicalidade no sentido etimológico da palavra: buscando ir à raiz das coisas, atingir sua essência e desvendar suas contradições a partir de uma perspectiva marxista (Castro, 1983, p.7).

A criminologia interacionista desvela o processo de criminalização, mas não aponta saídas para atacá-lo, enquanto na criminologia critica o faz denunciando as relações sócioeconômicas que permeiam a interação entre esses dois grupos.

Logo, a criminologia crítica vai além da interacionista no sentido de que, para a crítica, a criminalidade, além de ser uma construção social, é uma imposição daqueles que têm mais poder econômico-social sobre aqueles que têm menos:

\footnotetext{
${ }^{17}$ Nesse mesmo sentido Pires (1992, p.3) detecta a partir dos anos 70 o surgimento de “duas criminologias”: criminologia da reação social de um lado e uma criminologia da passagem ao ato de outro
} 
"Se o grupo é politicamente influente, os membros do grupo se asseguram a elaboração de uma lei, e assim, a cooperação do Estado no seu esforço de proteger seu valor".

(Sutherland apud Baratta, 1981)

Dentro desta perspectiva, todo o crime é um ato político na medida em que reflete as contradições do sistema social, e tanto a causa quanto a solução para a criminalidade residiriam na alteração das estruturas econômicas- sociais. Uma vez resolvida a questão social, estariam resolvidas a questão da criminalidade e seus desdobramentos. Se as causas estruturais da delinqüência emergem do capitalismo, o fim desse sistema levaria, conseqüentemente, ao fim da criminalidade.

\subsection{Crime enquanto construção social}

A criminalização de uma conduta não é fruto de uma construção da sociedade como um todo homogêneo, não advém da constatação da violação de valores sociais incontestáveis. Há condutas que não são aceitas socialmente e nem por isso são criminalizadas, enquanto outras são alvos da persecução penal sem que a sociedade as reprove. ${ }^{18}$

Para Becker (1971, p.19) o fato de que o desvio é criado pela sociedade constitui uma de suas características centrais. Não é a qualidade do ato que determina a conduta desviante, mas a aplicação das regras e sanções a esse ato; o ato em si não pode ser desviado, mas torna-se a partir de uma reação social negativa. Assim como o crime não tem uma existência autônoma que preexista às convenções sociais e aos sistemas legais, mas ao contrário, é fruto dos mesmos:

\footnotetext{
${ }^{18}$ Pires (1993, p.138) exemplifica algumas condutas negativas que não são criminalizadas: a violência policial, acidentes de trabalho por negligencia patronal ou as mortes causadas por produtos farmacêuticos, etc... Ou mesmo criminalizadas (previstas em lei) não chegam a sofrer persecução penal.
} 
“O desvio e a criminalidade não são qualidades intrínsecas à conduta, ou realidades ontológicas, mas uma qualidade/etiqueta atribuída a determinados sujeitos atrás de complexos processos de interação social”.

(Andrade, 1996, p.280)

Não há diferença ontológica entre crime e outro fato não punível pelo direito penal, assim como não há nada que una os crimes enquanto uma categoria, além da própria previsão de aplicação da pena. Nos dizeres do criminólogo norueguês Louk Hulsman não se pode identificar qualquer estrutura comum às condutas ditas criminosas a não ser o fato que o sistema de justiça criminal está autorizado a intervir contra eles (Hulsman, 2004, p. 43).

Da mesma forma, há condutas previstas na legislação penal cujos agentes não são alvo do sistema de justiça. As pessoas qualificadas como desviantes não compõem uma categoria homogênea que se justifica por características de personalidade e vivências sociais que as levariam ao crime, mas por serem justamente as que "compartilham a qualificação e a experiência de serem consideradas marginais” (Becker, 1971, p.18).

Contudo, pode-se estabelecer uma relação entre essas características e a criminalização, não no sentido de que aquelas levam ao cometimento do crime, mas de que certas pessoas estão mais propensas a serem qualificadas enquanto desviantes do que outras. Essas características, que elevam a vulnerabilidade de certas pessoas ou grupos perante a seletividade do sistema penal, podem explicar o fato de que algumas pessoas são qualificadas como desviantes sem ter cometido delito, e outras, ainda que o cometam, não recebem essa qualificação.

O fato de uma pessoa ter infringindo uma regra não implica necessariamente o reconhecimento social e a conseqüente sanção aplicável ao fato. Augusto Thompson (1998), ao analisar a questão que dá título à sua obra “Quem são os criminosos?” ${ }^{19}$, alerta que identifica-se como criminoso aquele que infringiu a legislação penal, porém criminoso é aquele que além de infringir a norma penal é punido pelo sistema de justiça, ou seja, percorre um longo caminho que se inicia com a infração à regra penal, passa pelas instâncias policiais e

${ }^{19}$ Primeira edição publicada em 1983 (Rio de Janeiro, Achiamé). 
judiciais, até sentença condenatória e a passagem pelo cárcere. Normalmente é o individuo que cumpriu ou está cumprindo a pena privativa de liberdade é tido como criminoso e identificado como transgressor das regras penais. ${ }^{20}$

\subsection{Crime, desvio e situação problemática: a linguagem enquanto construtora de significados}

"A linguagem vai ter, ao longo de todo seu percurso e nas suas formas mais complexas um valor expressivo que é irredutível (...), se a linguagem exprime, não o faz na medida em que imite e reduplique as coisas, mas na medida em que manifesta e traduz o querer fundamental daqueles que falam."

(Foucault, 2002-A, p. 401)

De acordo com Michel Foucault em As palavras e as coisas (2002), a linguagem é o lugar onde a verdade se manifesta e se enuncia, mas não no sentido de que existe uma verdade a ser desvelada, esperando que a traduzam em palavras; mas, ao contrário, a elaboração do discurso é constitutiva da realidade. A linguagem não só nomeia as coisas, mas lhes atribui significado.

A verdade é construída à medida que se interpreta a realidade e se escolhem os enunciados e a linguagem adequados para tanto. Nesse sentido, não há linguagem neutra, porque a interpretação sempre pressupõe uma escolha. Segundo Foucault (1996, p. 20), na vontade de proferir um discurso verdadeiro o que está em jogo é desejo e poder ${ }^{21}$.

As chamadas práticas discursivas, longe de ser um mero conjunto de enunciados, têm a função de determinar o que e como pode ser dito, estabelecendo as maneiras e possibilidades de compreender o mundo. A hegemonia do saber penal na resolução dos conflitos tem como conseqüência a construção de uma verdade acerca da delinqüência e a naturalização da

\footnotetext{
${ }^{20}$ Como ouvi de um preso certa vez "Eu sou ladrão porque sou carimbado", no sentido de que a diferença entre ele e os outros que haviam cometido crimes era o fato de ele estar preso e eles não.

${ }^{21}$ Sendo que o discurso não é um meio para chegar-se ao poder, mas o exercício do poder em si mesmo.
} 
solução punitiva, de modo a limitar qualquer outra forma legítima de abordar e resolver o problema $^{22}$.

Tendo em vista que a linguagem "possibilita o estabelecimento de legitimidade da justiça criminal” (Hulsman, 2004, p. 39), Becker (1971, p. 26) sugere que seja reservada a utilização do termo desvio àquelas condutas que foram assim classificadas pelo sistema de controle, e que se utilize o termo comportamento transgressor para nos referir às ações que violam regras sociais, já que o desvio não é uma qualidade pertencente à conduta, mas uma etiqueta que surge da interação do individuo com o sistema de controle.

Nesse sentido, tanto o termo crime quanto desvio pressupõe uma reação social negativa, advinda de uma norma- ou se tratando de crime, a própria lei- que traça a linha que dividindo os indivíduos em categorias antagônicas: o normal do anormal, o "homem de bem” do desviante, o “dentro da lei” do delinqüente.

Costuma-se conceber a criminalização como uma resposta do sistema penal a determinado comportamentos. Mas antes de ser reposta ela mesma constitui o próprio evento e fixa o modo como o sistema social deve responder a ele (Hulsman, 2004, p.52).

Diante de uma situação problemática surge uma imensa gama de possibilidades de interpretações e reações, sendo que o significado que se atribui à ação influenciará no tipo de resposta que será dada a ela (reação). A simples utilização da denominação crime/delito para designar determinados comportamentos problemáticos já exclui outras formas de reação social que não a punitiva (Hulsman, 1985, p. 102).

\footnotetext{
${ }^{22}$ Daí também a critica de Foucault à funcionalidade do discurso criminológico, na medida em que é "inteiramente utilitário" e cumpre a função de justificar a necessidade das medidas punitivas (Foucault, Sobre a Prisão, in 2004, p.138).
} 


\subsection{Propostas para uma criminologia clínica ${ }^{23}$ e crítica}

"O defeito do construcionismo social é que ignora a realidade objetiva... Pois a realidade existe, e não somente a medida da interpretação e da mente das pessoas, ainda que o observador também faça parte dessa realidade, $e$, portanto ele deva ser objeto de análise. Para o construcionismo se apaga a realidade exterior ao ser totalmente transladada para a subjetividade do observador, com o qual se cai no extremo oposto”.

(Castro, 1983, p.7)

Parece à primeira vista que uma criminologia clínica que tem essencialmente como objeto de estudo o indivíduo seria incompatível com os pressupostos críticos consolidados a partir da década de 60. Porém, alguns criminólogos estão empenhados na construção de uma criminologia voltada para o sujeito, que não se afaste dos pressupostos críticos, a partir do estudo das condutas transgressoras, não enquanto violadoras da lei penal, mas enquanto comportamentos problemáticos, anti-sociais.

Na tentativa de aproveitar as contribuições trazidas pela criminologia da reação social sem se abster da perspectiva individual, Álvaro Pires (Universidade de Otawa, Canadá) e François Digneffe (Universidade Católica de Louvain, Bélgica) tentaram conciliar essas duas perspectivas (aparentemente inconciliáveis), buscando romper com a incomunicabilidade das “criminologias” feitas a partir do paradigma da reação social e da passagem ao ato. Mas foi Cristhian Debuyst, psicólogo e professor da Universidade Católica de Louvain, o primeiro a realizar essa aproximação, ao se apoiar na criminologia da reação social sem abandonar os comportamentos e as situações problemáticas. ${ }^{24}$

\footnotetext{
${ }^{23}$ Também chamada de criminologia da passagem ao ato (Pires, 1992) ou criminologia penitenciária (Castro, 1983)

${ }^{24}$ Jorge Figueiredo Dias e Manuel da Costa Andrade parecem adotar também uma postura conciliatória ao defender a superação da antinomia entre o "jurídico" e "natural ou sociológico", que corresponderiam respectivamente ao paradigma da reação social e o paradigma do fato social bruto da teoria de Debuyst (Dias \& Andrade, 1997, p.88).
} 
A escolha de um ou outro paradigma nos obriga a uma visão reducionista do fato criminal, uma vez que o paradigma de fato social bruto negligencia o fato de que a realidade criminal passa por uma construção social e está comprometida com as relações de poder existentes na sociedade, enquanto o paradigma da definição social deixa de lado a realidade factual das transgressões e a existência de conseqüências negativas de certos comportamentos, abstraindo, por exemplo, a existência de vitimas, dos danos, da violência e das relações conflituosas do individuo enquanto ser concreto.

Diante da insuficiência de uma abordagem feita a partir de um só paradigma, Álvaro Pires (1993, p.133) propõe uma reconstrução histórica do campo de análise, estabelecendo uma ponte entre o estudo das situações problemáticas (da conduta em si) e o estudo do processo de criminalização (do controle que recai sobre ela). E a pensa a partir da assunção de um terceiro paradigma: o das inter-relações sociais.

Uma nova criminologia clínica pautada pelo paradigma das inter-relações sociais concebe o sujeito dentro de sua totalidade e parte de noções como ator social, definição da situação, situação conflituosa, comportamento problemático, relações de poder e estigmatização, para compreender a realidade criminal. Esse paradigma consistiria na articulação entre o eixo de criação e aplicação das leis com o eixo dos conflitos entre os atores sociais ${ }^{25}$, o qual compreende dois tipos de relação de poder: entre indivíduos e grupos de indivíduos, e entre individuo e Estado na forma do sistema penal (Pires, 1993, p.155).

Por este ângulo, a criminologia clínica ganha outros contornos: afasta-se da etiologia propugnada pela escola positivista italiana e, conseqüentemente, da busca das causas do comportamento criminoso, em defesa da compreensão global da dinâmica em que está inserido o individuo que delinqüiu (ou de acordo com a terminologia da reação social, que foi selecionado pelo sistema penal). Para tanto, essa nova clinica busca situar o comportamento

\footnotetext{
${ }^{25}$ Os quais corresponderiam ao paradigma da reação social e do fato social bruto, respectivamente.
} 
delinqüente em um contexto próprio, assim como determinar quais os atores sociais envolvidos naquele fato e quais as suas conseqüências para o grupo social. ${ }^{26}$

A delinqüência passa a ser situada dentro de um contexto psico-social maior, a partir de uma relação conflituosa anterior. O foco da criminologia clínica continuaria no comportamento problemático e na pessoa que foi sentenciada, porém a partir de uma mudança analítica: ao invés de buscar neles as causas do crime, pretende situá-los dentro do seu contexto históricosocial.

\begin{abstract}
“A partir, no entanto, da compreensão do crime como expressão de conflito, o foco de atenção deve mudar para o cenário do conflito, deve se deslocar da pessoa do apenado para o complexo de relações entre ele e a sociedade e todo seu contexto familiar, tendo-se em vista a história de segregação e exclusão de que o preso é vítima”.
\end{abstract}

(Sá, 2001, p.175)

A proposta de Debuyst é de um retorno ao sujeito, mas ele enquanto ator social, possuidor de um conjunto de valores e significações, o qual "escolhe dentro de um campo de possibilidades as diversas formas de se relacionar” (Debuyst, 2001, p.11) e não que é determinado por suas condições, ou simplesmente “alvo” do sistema de controle.

Ademais, essa perspectiva clínica expande sua análise a outros atores do sistema penal: às instâncias judiciais, legais, familiares, escolares, responsáveis pela criação das regras legais e sociais, tanto para compreensão da realidade criminal como para fins de execução criminal:

“As estratégias de reintegração social devem centralizar-se, não na pessoa do infrator, mas nas relações entre as partes em conflito, sempre priorizando o

\footnotetext{
${ }^{26}$ Para elucidar de que forma seria feita essa “construção de fato” da infração, DEBUYST (1992, p.65) trata de quais elementos comporiam a interação em um roubo de uma grande loja. Para ele essas lojas de departamento, independentemente das características do transgressor, já criam um tipo próprio de inter-relação com os objetos e as pessoas, a começar pela facilidade de pegar as mercadorias, depois por representar a transformação de um estabelecimento comercial em um verdadeiro lugar público; e, ainda, por seus produtos habitarem o imaginário popular enquanto sonhos de consumo muitas vezes inacessíveis a maior parte da população.
} 
pensamento, a reflexão, enfim, a simbolização como forma de mediação das respostas".

(Sá, 2001, p. 169)

Dessa forma, o crime representaria tanto uma realidade construída pelo sistema penal como um objeto relacional, ou seja, o crime não é só um ato censurável, mas fruto da relação entre determinado comportamento e a lei, entre a maneira de fazer e a maneira de definir, entre a situação-problema e a maneira de resolver a situação. Para Pires (1993, p.139) o pesquisador tem que aceitar essa dupla asserção de que o crime é um tipo de comportamento e uma questão de definição, concomitantemente, não sendo possível fazer uma opção por uma ou outra postura.

É necessário, portanto, considerar o crime dentro desta lógica paradoxal: ele não é somente um fato social que existe por si mesmo, assim como não é uma pura construção normativa: é os dois ao mesmo tempo. A realidade criminal deve ser considerada a partir de suas duas dimensões: uma dimensão comportamental (enquanto um fato bruto) e uma dimensão normativa (enquanto uma qualificação criminal).

Admitindo o pressuposto crítico de que o crime é uma construção social, mas sem desconsiderar que a própria ação existe como um fato social, há de se diferenciar o crime como situação-problema carregada de negatividade social da noção institucional de crime. ${ }^{27}$ Por isso, esses criminólogos ${ }^{28}$ passaram a denominar o comportamento definido como criminal como comportamento problemático ${ }^{29}$ já que ele não é um comportamento criminoso por si só, ou seja, depende da construção penal, mas ao mesmo tempo existe enquanto uma realidade problemática.

\footnotetext{
${ }^{27}$ Ver os conceitos de desvio e comportamento transgressor de Becker (1971) - item 1.2. deste Capítulo.

${ }^{28}$ No mesmo sentido das propostas do Howard Becker e Louk Hulsman já expostas anteriormente.

${ }^{29}$ Comportamento problemático (Debuyst, 1995); comportamento ou situação problema, negatividade social ou ações anti-sociais (Pires,1993); e, ainda comportamentos sociais danosos, situações conflituosas, problemáticas (Marteau, 1997).
} 


\subsection{Criminologia Clínica em Zaffaroni: a clínica da vulnerabilidade}

Como já visto, a criminologia crítica central tende a negar ou descartar a criminologia voltada para o individuo. Para Zaffaroni (1998, p.24) essa resistência somente teria sentido em relação a uma clínica etiológica que se esgota no plano bio-psicológico; pois a partir da constatação de que são selecionados pelo sistema penal não só os socialmente vulneráveis, mas os psiquicamente vulneráveis, mostra-se plenamente justificável a existência de uma criminologia de abordagem sócio-psico-biológico centrada no estudo da vulnerabilidade individual perante o sistema.

O criminólogo argentino propõe a substituição de uma etiologia da conduta criminal por uma etiologia da vulnerabilidade, ou seja, ao invés da criminologia se debruçar sobre a biografia do indivíduo, tentando explicar a formação de sua identidade delinqüente, ela compreenderia a história de fragilização daquela pessoa perante o sistema punitivo com o objetivo de revertê-la, tentando evitar assim a criminalização secundária e quebrar a “profecia-que-se-auto-realiza”.

Visando integrar os pressupostos críticos com uma atuação clínica, Eugênio Raul Zaffaroni desenvolveu a chamada clinica da vulnerabilidade ${ }^{30}$ enquanto "um saber que permita ajudar as pessoas criminalizadas a reduzir seus níveis de vulnerabilidade” (Zaffaroni, 1998,p.26) ou "uma técnica tendente a ensinar ao homem a não oferecer a face à bofetada do sistema penal” ou "uma clínica orientada à superação das características individuais que fazem com que a pessoa se meta no estereótipo e assuma o papel que lhe é assinalado” (Zaffaroni, 1990, p. 64).

A clínica da vulnerabilidade em muito difere da clínica tradicional, uma vez que esta pressupõe uma superioridade moral dos outros em relação ao preso, reafirmando a existência de padrões de normalidade e anormalidade, onde o operador e a sociedade constituem o normal e o outro o desviante, o outsider, o marginal; enquanto aquela pressupõe o respeito à verdade de cada um, propondo um diálogo de subjetividades, sem que uma parte se sobreponha à outra:

\footnotetext{
${ }^{30}$ Zafaronni escolhe mudar a denominação criminologia clinica para clinica da vulnerabilidade para justamente romper com a associação dessa criminologia com aquela outra formulada pela escola positivista italiana.
} 
"A clinica da vulnerabilidade não é uma colocação ao nível de superioridade ética, de superioridade moral frente aos criminosos contra a propriedade. Simplesmente dizer: desse jeito não. Se você escolhe o trabalho de freguês da cadeia é uma escolha; mas mostrar, tornar consciente essa escolha, é uma comunicação existencial de perceber que, no fundo dessa escolha, acha-se um erro, que conduz à deterioração e à destruição da pessoa e, na nossa realidade, à morte"

(Zaffaroni, 1990, p. 59)

\subsection{Tarefa da criminologia clínica e crítica}

A principal tarefa da criminologia clínica e crítica seria contextualizar o comportamento problemático, assim como o seu autor a partir de sua história, elucidando as relações conflituosas nas quais ele está envolvido, de modo a compreendê-lo dentro de sua individualidade e fortalecê-lo perante o sistema punitivo.

Porém, para a consolidação de uma criminologia clínica que se queira crítica, que busque a emancipação do homem enquanto sujeito ativo de sua história, deve-se respeitar alguns pressupostos consolidados pela crítica, de forma a não retroceder ao determinismo ou à etiologia criminal da escola tradicional, que reduz o homem a um objeto de intervenção penal, ao mesmo tempo em que o considera como o verdadeiro produtor da realidade criminal.

O primeiro pressuposto para uma abordagem clínica crítica é de reconhecer o indivíduo selecionado pelo sistema penal como igual aos demais:

"Só é possível observar o delinqüente como ator social que interage com outros não delinqüentes sem perder de vista não existirem características especificas dos atores sociais delinqüentes que permitam tipologias para o estudo da questão criminal”

( Baratta apud Marteau, 1997, p. 75) 
O segundo pressuposto seria observar o indivíduo delinqüente não a partir de uma abordagem etiológica, mas com o fim de obter uma compreensão global da historia daquele indivíduo, interpretando o sentido de seu comportamento e o contextualizando na sua vida:

\begin{abstract}
"O comportamento humano, como realidade exterior, não é mera representação ou fenômeno, mas um complexo de valores que se interrelacionam a todo momento e com todos. Compreender a história de uma coletividade ou de uma personalidade é se relacionar com ela e com os próprios valores"
\end{abstract}

(Velo, 1998, p.132)

O terceiro pressuposto, ao lado da abordagem psicológica ou micro-sociológica realizada pela clínica, consistiria em não perder de vista o modelo do conflito construído pela perspectiva macro-sociológica da crítica. Ainda que seja importante olhar para aquele que foi criminalizado dentro de suas peculiaridades, não esquecer que o mesmo é um sujeito histórico, fruto de uma sociedade de classes e imerso nas relações de poder dessa sociedade.

O quarto pressuposto seria reconhecer que a delinqüência é uma realidade construída, que não existe o crime ou o criminoso independentemente de uma instância que lhe atribua esse rótulo. Uma vez que nem todos os comportamentos problemáticos são criminalizados, e nem todos os comportamentos criminalizados são problemáticos, o que define o que é crime ou não, não é a reprovação social do ato (como no modelo de sociedade de consenso), mas um poder que constrói essa significância.

O quinto pressuposto é de que o sistema de controle é seletivo e reprodutor de violência. São selecionadas tanto as ações a serem criminalizadas pelo Direito Penal, como os tipos de pessoas que vão ser julgadas e condenadas por esse sistema (as mais vulneráveis psicosocialmente) e que, após a intervenção penal, sairão mais enfraquecidas ainda. 
Nesse sentido cabe reproduzir parcialmente o conceito com enfoque crítico elaborado por Alvino Augusto de Sá ${ }^{31}$ por nos parecer essencial à construção brasileira de uma nova criminologia clínica:

“Criminologia Clínica é uma ciência interdisciplinar que visa conhecer o homem encarcerado enquanto pessoa, conhecer sua história de marginalização social, pela qual ele sofreu um processo de deterioração social e, até mesmo psíquica, fragilizando-se perante o sistema punitivo e se deixando criminalizar pelo mesmo. Deve preocupar-se em estudar, não fatores criminógenos, mas os fatores sociais e individuais que promoveram e facilitaram a criminalização por parte do sistema penal. Deve preocupar-se em estudar a vulnerabilidade do encarcerado perante o sistema punitivo, distinguindo a vulnerabilidade anterior à intervenção penal daquela que é conseqüência da intervenção penal”.

(Sá, 2005, p. 15)

Se a criminologia da reação social adotou o paradigma construtivista, para a partir dele entender os processos de definição social do crime e da figura do criminoso, Debuyst e Pires acabam por ampliar esse objeto ao propor a reconstrução do crime em um contexto mais amplo. Caberá à clínica situar o processo de definição social tratado pela crítica, dando-lhe materialidade e concretude ao analisar não uma construção abstrata e genérica, mas como foi o processo de definição de determinado crime e agente: o lugar do fato, a representação do acontecimento e as relações do autor com os demais atores do processo.

À medida que a criminologia da reação social busca compreender o processo de criminalização, o faz a partir da desmistificação do sistema normativo, denunciando a suposta

31 Sá entende clínica como a criminologia aplicada à execução penal. Para uma conceituação precisa da criminologia clínica sobre o enfoque tradicional, moderno e crítico ver SÁ, Alvino Augusto de. Sugestão de um esboço de bases conceituais para um sistema penitenciário. Manual de projetos de reintegração social. Secretaria de Administração Penitenciária / Departamento de Reintegração Social do Estado de São Paulo, 2005: 13-21. 
neutralidade do direito penal, a homogeneidade dos valores sociais e o poder do sistema econômico-social. Trata-se de um caminho que ainda que pautado pelo materialismo histórico, se limita ao campo da abstração, uma vez que trata de um homem genérico em determinada condição social que se relaciona com um sistema perverso.

Já a proposta dessa “nova clínica” consiste em uma “reconstrução de fato” (Debuyst, 1992) a partir da análise das circunstâncias especificas que envolvem determinado fato e da atenção às singularidades dos atores que o produziram.

Logo a tarefa dessa criminologia clínica e crítica seria a tradução do significado do evento e a contextualização do mesmo, sem perder de vista que o crime é uma construção social. Tratando-se a presente pesquisa de um estudo sobre a identidade e as repostas à prisionização, não há como optarmos por um ou outro paradigma.

“Um estudo sobre a internalização de uma identidade desviante antecedida / seguida de uma reação estigmatizante constitui um exemplo de pesquisa que diz respeito tanto ao paradigma da definição social, quanto do fato bruto, ao estudar ao mesmo tempo o comportamento e a ação do sistema penal”.

(Pires, 1993, p.148)

Pois enquanto a criminologia pautada pelo paradigma etiológico se preocupava em estudar o indivíduo e em tentar readequá-lo socialmente, aprisionando-o em uma identidade, e a criminologia pautada pelo paradigma da reação social busca realizar o estudo do sistema, denunciando sua seletividade com o objetivo de modificar as relações de classe, mas esquecendo-se das subjetividades; essa “terceira via”, pautada no paradigma das inter-relações sociais, focaria na relação ente os dois (individuo e sistema), dando cabo à denúncia do sistema de controle, ao mesmo tempo em que busca compreender a relação do indivíduo com o sistema e com seu meio social, contextualizando as situações problemáticas vivenciadas por esse indivíduo, de forma a fortalecê-lo perante a seletividade do sistema punitivo. 
De modo a manter a coerência do trabalho, uma vez que se parte do paradigma das interrelações sociais e de uma perspectiva interacionista para uma compreensão das conseqüências do processo de prisionização sobre o preso e as formas que este tem de responder a ele, será adotada a mesma perspectiva para a formulação de uma conceituação da identidade e elucidação dos processos de formação da subjetividade, para então, no Capítulo 3, relacionálos com a prisão em si.

Para entender como as identidades sofrem um processo de transformação e como reagem diferentemente à execução penal, o próximo capítulo será dedicado a uma conceituação de identidade a partir de uma perspectiva interacionista da Psicologia Social. 


\section{CAPÍTULO 2 \\ IDENTIDADE}

Para que seja analisada a relação entre a identidade ${ }^{32}$ do indivíduo preso e as formas de ajustamento em relação às normas institucionais e para-institucionais é necessário, anteriormente, explicitar a concepção de identidade na qual esta pesquisa se baseia, assim como evidenciar os processos que a constituem e a sua dinâmica.

Primeiramente, cabe ressaltar que não se trabalhará com um conceito estático de identidade, como um conjunto de características imutáveis que acompanham a vida de um indivíduo adulto e o determinam, assim como às suas relações.

A temática da identidade há muito perdeu seu caráter estático-metafísico para adquirir dimensões sociais e dinâmicas. Principalmente a partir dos anos 50, com a sistematização da Psicologia Social e a superação da dicotomia indivíduo x sociedade.

Sob essa perspectiva, toda a Psicologia - ao conceber o ser humano como produto da história e da sociedade, evitando qualquer análise fragmentada ou isolada de seu contexto -passa a ser social (Lane, 2004, p.19).

À medida que se passou a compreender a identidade a partir da relação indivíduo-sociedade, as chamadas ciências psi deixaram a abordagem exclusivamente individual, para se abrirem à perspectiva sócio-antropológica, construindo assim, um campo de saber transdisciplinar, cujo

\footnotetext{
${ }^{32}$ Três conceitos poderiam ter sido usados neste trabalho para que fosse alcançado o objetivo da pesquisa (relação do indivíduo com as regras prisionais): personalidade, subjetividade e identidade. O primeiro (personalidade) está ligado a uma perspectiva mais biológica e individual - inclusive a padrões de normalidade/ anormalidade - e designa o conjunto de características psicológicas do individuo que determinam como ele atuará no mundo. O segundo (subjetividade), ao contrário, pressupõe a relação do individuo com o mundo social, e ao lado da objetividade (atuação no mundo) comporia a dimensão do sujeito (Maheirie, 2002, p. 37). Já o terceiro conceito (identidade) abrange tanto a dimensão individual quanto social, representando a síntese desses contrários (individual/social, semelhanças/diferenças, proximidades/distâncias). Escolhemos utilizar o conceito de identidade porque ele surge com a psicologia social (perspectiva da psicologia adotada nessa pesquisa) e ainda porque a concepção do homem enquanto ser social, que transforma e é transformado pelo ambiente, vai de encontro com outras bases teóricas que norteiam o presente trabalho no âmbito da criminologia, tais como o labelling approach e o paradigma das inter-relações sociais.
} 
objeto não pode ser compreendido à luz de uma só ciência. E é essa a abordagem desta pesquisa.

\subsection{Conceituação de identidade}

“E quando acordava? Quando acordava não sabia mais quem era. Só depois que pensava com satisfação: sou datilógrafa e virgem, e gosto de coca-cola. Só então vestia-se de si mesma, passava o resto do dia representando com obediência o papel de ser"33

(Macabéa em A hora da estrela, Clarisse Lispector)

A partir dos pressupostos acima elencados a identidade pode ser entendida como a síntese dos sentimentos e concepções que o individuo tem em relação a si mesmo a partir de suas representações sociais. Ela é formada, confirmada e transformada em um processo dinâmico, e é re-atualizada a cada interação social.

O homem é um ser social. Logo, a compreensão individual de identidade não pode ser destacada de seu contexto histórico: a identidade é uma construção social à medida que o ambiente não só influencia a identidade, mas a constitui. O homem cria a si próprio, assim como constrói os outros homens e a sociedade em que vive, ao mesmo tempo em que é construído por eles.

A identidade se constitui na dinâmica comportamental, e não por um conjunto de características do indivíduo. Longe de ser um ente transcendental que atua sobre a realidade, ela é a própria realidade.

\footnotetext{
${ }^{33} \mathrm{~A}$ personagem de Clarice Lispector antes de sair de casa fazia a síntese de quem era, do que gostava e quais os papéis que teria de representar durante o dia, e isso lhe trazia segurança ("pensava com satisfação") principalmente por confirmar a sua mísera existência. Além desses papéis conscientes, outros lhe estavam agregados: Macabéa era alagoana, pobre e mirrada, submissa e sonhadora, que passava pela vida sem ser percebida. Porém, parte desse padrão é alterada no momento em que ela encontra uma cartomante, que a elogia, a trata com carinho e lhe prevê um belo futuro. Essa interação vai ser crucial na forma de ela se enxergar e se colocar para o mundo, modificando e constituindo a identidade de Macabéa.
} 
Ela consiste numa multiplicidade de papéis atualizados na dinâmica social, e ao mesmo tempo, na síntese deles, numa conformação única que garantirá as individualidades biográficas. Essa multiplicidade de papéis é a manifestação da identidade em movimento, enquanto processo que se renova no dia-a-dia, na comunicação com os outros. Mas a identidade é também produto, um denominador comum que nos acompanha nesse movimento, um padrão pelo qual se reconhece e se é reconhecido, de forma a conformar as expectativas sociais.

A identidade é ao mesmo tempo produto e processo. Produto como a síntese de todas as nossas representações, e processo, enquanto as representações em si mesmas. Segundo Ciampa (2004, p.61) a identidade é “uma totalidade contraditória múltipla e mutável, mas una”.

Enquanto processo a identidade consiste no que Santos (1999) denomina "identificação em curso” ou o que Ciampa (2005) chama de “metamorfose, morte-e-vida”. Esse processo identitário se desenvolve no dia-a-dia, a partir das circunstâncias da interação entre o próprio ator e o público, e de suas expectativas recíprocas. A identidade se forma a partir de uma variedade de eus, que representam diversos papéis perante públicos variados.

Essa rede de representações é apenas uma das facetas da identidade, pois a identidade também é produto caracterizado pela coerência e unicidade. Uma conformação singular que diferencia o indivíduo dos demais, uma totalidade formada pelo conjunto dos eus, um padrão único.

A identidade se compõe de dimensões aparentemente contraditórias, tais como a individual e social, a igualdade e a diferença, a unidade e a multiplicidade. E é a síntese desses elementos que vai garantir a individualidade ${ }^{34}$.

\footnotetext{
${ }^{34} \mathrm{O}$ termo individualidade aqui é usado aqui para se referir ao que difere uma pessoa das demais, a consciência de ser único dentre os seus semelhantes. E é produto da síntese entre os papéis sociais que ela ocupa e suas características pessoais; tal combinação sempre resultará em uma conformação única, exclusiva daquele indivíduo.
} 
Logo, apesar de haver semelhança nos papéis sociais que são representados, os personagens e a identidade sempre serão diferentes, pois cada junção e combinação de papéis em determinado indivíduo resultarão numa conformação única.

Pelas semelhanças e diferenças se constrói a identidade. O próprio significado da palavra identidade traz essa dubiedade, já que pode designar tanto a igualdade entre duas coisas quanto o conjunto de características exclusivas do sujeito, que o diferencia dos demais e pelas quais se é reconhecido.

A pessoa se apresenta ao mundo com um nome, que diz a ela e aos outros quem ela é. O prenome é o responsável por diferenciá-la das outras pessoas, enquanto o sobrenome a iguala aos seus familiares, àqueles de mesma origem (Ciampa, 2005). A pessoa se torna o seu nome, por isso traz incômodo quando alguém o confunde com o de outra pessoa ou o esquece. Apesar do fato de se imaginar sendo chamado de outra forma causar certo estranhamento, no decorrer da vida uma mesma pessoa recebe epítetos diferentes, na forma de apelidos, sobrenomes, alcunhas, seja devido a relações familiares ou de amizade, status social, categoria profissional etc.

Quando é perguntado - quem é você? - o indivíduo geralmente identifica-se com o seu nome, seguido de categorias que se acredita pertencer, entre as quais a nacionalidade, idade, estado civil, profissão etc.

Mas o que realmente lhe determina são suas ações, pois a partir delas é que ele se relaciona com o mundo. As ações incorporam-se à identidade e assumem formas substantivadas, ou seja, o verbo dá lugar a um substantivo e o sujeito passa a se valer dele para compor sua identidade. Logo, quando lhe perguntam - "o que você faz da vida?” - a tendência é responder "eu sou...”, e não "eu faço tal coisa".

O substantivo, ao contrário do verbo, é caracterizado pela permanência, constância. As ações estão ligadas a um tempo e espaço determinados, porém, ao serem substantivadas fixam-se, depreendem-se de qualquer referência histórica: o tempo do verbo se torna invariável no 
substantivo. Por isso é comum se dizer, por exemplo: eu sou professor, e não eu leciono ou eu lecionei.

Ademais, o substantivo subsiste à ação: mesmo não sendo mais realizada a ação, continuamos nos identificando com ela (Ciampa, 2005). É o caso dos aposentados ou desempregados, que mesmo sem exercer a atividade laboral continuam se identificando com o trabalho que exerciam.

É também a situação daquele que praticou o crime. Uma vez cometida a ação criminosa, o substantivo criminoso passa a acompanhá-lo, independentemente da reiteração dessa ação ou do tempo em que ela ocorreu. Isso porque o substantivo criminoso, além de estar ligado a uma ação, faz referencia a um estigma, o qual será tratado no item 2.3.

\subsection{Identidade enquanto representação de papéis sociais}

Erving Goffman, na sua célebre obra Presentation of self in everyday life, publicada originalmente em 1959, concebe a metáfora da vida enquanto teatro. Goffman (1985) emprega o modelo de representação teatral para explicar a interação entre as pessoas e as formas pelas quais elas dirigem e direcionam as informações a serem passadas ao seu público, que, na sua análise, deixa de ser o elemento passivo do teatro para participar da cena como ator, influenciando e sendo influenciado pelos demais.

Apesar da tendência em fixar a si e aos outros em determinados papéis, a dinamicidade da identidade não ficaria comprometida, pois a representação desses padrões não diminui a complexidade da interação. As cenas, por mais que bem ensaiadas, estão sempre suscetíveis a interferências externas. A interação permanece imprevisível, carregada de expectativas e imagens complexas. 
Os papéis que um indivíduo escolhe ou cujas representações lhes foram outorgadas precisam ser confirmados no processo de comunicação social: é preciso convencer os outros de que "ele serve para aquele papel”, sob o risco de ter a sua representação deslegitimada.

Esse convencimento é fruto da coerência entre linguagem, postura e vestuário adotados e as expectativas dos demais em relação àquele determinado papel. Por isso o encontro das pessoas fora dos papéis em que normalmente interagem, como no caso de um aluno encontrar o professor "à vontade" em uma viagem, ou mesmo de um fã encontrar seu ídolo realizando alguma atividade ordinária, causa certo desconforto para ambas as partes.

Segundo Goffman (1985), papéis são direitos e deveres ligados a uma situação social. Cada postura assumida por um indivíduo desperta uma série de expectativas, em si e nos outros. Estas expectativas conformarão obrigações e convenções sociais, que colocarão à prova sua aptidão para o exercício do papel.

Os eus que se apresentam variam de acordo com as escolhas dos papéis que se pode representar em determinada cultura. O repertório de papéis possíveis será determinado pela estrutura social, contudo ele varia de individuo para individuo, de acordo com sexo, idade, aparência e classe social, entre outros.

É "natural" na sociedade que o papel de criminoso seja representado por determinado tipo social: geralmente homem, jovem, de origem humilde, crescido em uma família desestruturada etc. Quando há um rompimento dessa lógica, fica-se com a impressão de que "algo não se encaixa”, comprometendo a harmonia na combinação dos papéis representados por uma mesma pessoa e, conseqüentemente, perturbando a expectativa social que identifica determinadas atitudes como pertencentes, exclusivamente, a certos tipos de pessoas.

Daí a importância de haver certa harmonia entre os diversos papéis que são representados, pois caso o "leque de papéis" do individuo seja composto de partes muito discrepantes e 
contraditórias entre si, será difícil para o público compreendê-lo como uma unidade, ou de aceitar um e outro papel, concomitantemente ${ }^{35}$.

Conforme a pessoa muda de grupo social ou de platéia, ela pode assumir facetas e comportamentos diferentes a partir da representação dos mais variados papéis. É esse repertório o responsável por compor o seu “eu”, que será único à medida que as possibilidades de combinação de papéis são infinitas e as personagens variam de ator para ator.

Apesar de haver repetição dos papéis sociais, a personagem é fruto da química entre o papel enquanto padrão social e aquele que o representa. Logo, mesmo que duas pessoas cumpram papéis idênticos, suas representações nunca serão iguais, assim como suas identidades não podem ser reduzidas a uma só.

E ainda que os papéis constituam padrões sociais, a interação não fica limitada a essas estruturas, ao contrário ela as desafia, já que a todo momento as personagens estão sendo testadas e modeladas:

\begin{abstract}
“Todos nós estamos continuamente empenhados num processo que dura toda a nossa vida - de construção, manutenção e remodelação do eu. Todas as atividades de autocriação - a experiência de novos eu,s a manutenção ou remodelação do eu estabelecido, o abandono de um eu antigo, talvez obsoleto consistem em grande parte em comportamentos que ajudam a confirmar nossas pretensões a nosso respeito e evitar o comportamento que tende a prejudicar essas pretensões”.
\end{abstract}

(Cohen, 1968, p. 208)

\footnotetext{
${ }^{35}$ Como no caso da combinação "menina-bonita-de-boa-família-universitária-inteligente” destoar do exercício do papel de criminosa: "Universitária, bonita, nascida em berço privilegiado,(...), tinha tudo para um futuro promissor. Boa aluna, até a quinta-feira 7 ela cursava o primeiro ano de direito na PUC de São Paulo, onde era vista pelas colegas como uma pessoa alegre e bastante simpática. Na madrugada da sexta-feira 8, porém, se tornou pública uma outra face de Suzane. Uma face extremamente cruel..." Isto é on line : http://www.terra.com.br/istoe/1728/brasil/1728_capa_crime.htm, acesso 09/05/2006.
} 
Os papéis são atualizados na própria vivência, no que Goffman (1985) denomina interação face-a-face, ou seja, na influência recíproca de um individuo sobre outro enquanto presença física imediata; conceito que deve ser reatualizado à luz da pós-modernidade, momento em que a presença virtual, imediata, adquire grande importância na conformação identitária.

As questões - "Quem sou eu nessa situação?” (Strauss, 1999), “Quem é meu público?”, “Quais são as expectativas de ambos?”- podem ser um caminho para determinar a identidade situacional, ou seja, qual o personagem que a pessoa está representando naquele momento e o que o público espera dele, como a pessoa deve agir de forma a convencer o seu público da sua representação.

\subsection{Identidade na prisão}

"Esta forma de poder aplica-se à vida cotidiana imediata que categoriza o indivíduo, marca-o com sua própria individualidade, ligao à sua própria identidade, impõem-lhe uma lei de verdade, que devemos reconhecer e que os outros têm que reconhecer nele. É uma forma de poder que faz dos indivíduos sujeitos”

(Foucault,1995, p.235)

Foucault, no trecho acima, descreve o processo oriundo dos mecanismos disciplinares de assujeitamento do indivíduo. Todos os indivíduos da sociedade disciplinar estão sujeitos à ingerência desses mecanismos de poder que categoriza, fixa a identidade e limita as possibilidades de ser. Sendo a prisão instituição disciplinar por excelência, os indivíduos a ela submetidos vivem mais agudamente o processo de assujeitamento.

A disciplina enquanto anatomia política do detalhe descrita por Foucault vai ao encontro do controle da instituição total analisada por Goffman nos anos 60. Goffman descreve a disciplina agindo das formas mais sutis, e, para ele, esse é seu aperfeiçoamento: ela adentra as esferas da vida silenciosamente, quase imperceptivelmente, na contenção dos gestos e ordenação do 
corpo $^{36}$, regulação e uniformização dos horários, inclusive fisiológicos, ligados ao ritmo especifico de cada corpo, o tempo de dormir, comer, mover-se.

Contudo, apesar de ser possível fazer várias aproximações das construções teóricas desses dois autores, a análise de Goffman está centrada na dinâmica interna da instituição total, detalhando como os mecanismos disciplinares se apoderam do individuo e as práticas são instituídas no dia-a-dia da instituição; já a Foucault interessa a funcionalidade da disciplina em um âmbito mais amplo, sua inserção no sistema econômico e social, coadunado com determinada racionalidade política. Conforme explica o próprio Foucault:

"Disseram que eu procurava fazer a mesma coisa que Goffman em sua obra sobre asilos, a mesma coisa, mas não tão bem. Não sou um pesquisador em ciências sociais. Não procuro fazer a mesma coisa que Goffman. Ele se interessa pelo funcionamento de um certo tipo de instituição total: o asilo, a escola, a prisão. De minha parte, procuro mostrar e analisar a relação que existe entre um conjunto de técnicas de poder e de formas: formas políticas como o Estado e formas sociais. O problema ao qual Goffman se prende é o da instituição mesma. $O$ meu é o da racionalização da gestão do indivíduo”

(Foucault, in Foucault estuda a razão do Estado, 2006, p. 319)

Enquanto o poder disciplinar em Foucault é essencialmente produtivo ${ }^{37}$, na análise microsociológica de Goffman, as conseqüências da disciplina no indivíduo submetido a uma instituição total são de caráter negativo, agindo no sentido de anular o indivíduo. Tanto que o autor denominou a mortificação do eu como uma das principais conseqüências na identidade do interno.

\footnotetext{
${ }^{36}$ A postura dos presos de andarem de braços para trás e cabeça baixa são manifestações da linguagem do corpo. Contudo, em uma reunião do Grupo de Diálogo Universidade-Cárcere-Comunidade (GDUCC) na qual estavam presentes membros da Universidade e da Administração da Penitenciária, notei que a postura de todos na roda era de alguma forma fechada, o corpo já se trancava, a disciplina sutil da prisão se impunha até mesmo no corpo daqueles que se achavam "fora dela".

${ }^{37}$ A discussão acerca do poder disciplinar será retomada no capítulo 4.
} 
Se para Goffman a identidade se constitui na administração e representação dos mais diversos papéis na vida civil, no caso do individuo preso (ou de outro que vive em uma instituição total) a representação de outros papéis é limitada: não há liberdade de escolha entre os diversos papéis e a possibilidade de representação concomitante de mais de um papel é afetada pela própria internação.

Goffman (1974) classifica como total a instituição que apresenta um fechamento acentuado caracterizado pela pouca comunicabilidade com o mundo externo, na qual o individuo desenvolve todas as suas atividades sobre uma mesma autoridade e controle e não há barreiras entre as diferentes esferas da vida: trabalho /família/ lazer. Essa instituição pode funcionar na forma de uma prisão, um manicômio ou mesmo uma fábrica ${ }^{38}$.

Toda a instituição tende ao fechamento e a exigir de seu membro a representação de determinado papel coerente com as expectativas e regras institucionais. Porém, na maioria dos casos, a vida do individuo não se limita àquela instituição, e ele possui outros espaços para manifestação identitária.

Já as instituições totais, exigem do indivíduo exclusivamente a representação do papel que dele se espera, impedindo que o mesmo se determine a partir de suas diversas posições e exista como uma multiplicidade.

“Na vida civil, a seqüencia de horários dos papeis do individuo (...), assegura que um papel que desempenhe não impeça a sua realização e suas ligações com outro. Nas instituições totais ao contrário, a participação automaticamente perturba a seqüência de papéis”.

(Goffman, 1974, p. 24)

\footnotetext{
${ }^{38}$ Não coincidentemente, o projeto arquitetônico de Jeremy Bentham, o Panóptico - além de poder ser aplicado na construção de estabelecimentos prisionais, poderia servir a qualquer instituição que quisesse manter sobre controle e disciplina um grande número de pessoas, fosse ela um hospital, uma escola ou uma fábrica. Tratou-se da elaboração de uma nova forma de poder, que receberia o nome a partir da análise foucaultiana de poder disciplinar.
} 
No dia-a-dia, a representação de um papel não afeta, necessariamente, o desempenho de outros: se é ao mesmo tempo pai, filho, vendedor, estudante, membro da igreja, fanático por futebol. Já nas instituições totais, alijadas do mundo externo, a representação do papel de internado compromete todos os demais.

Para Goffman, as mudanças nas crenças do indivíduo sobre si mesmo e dos outros em relação a ele dentro da instituição total levam ao que ele denomina processo de mortificação do eu ${ }^{39}$. A institucionalização compromete o referencial identitário do individuo, ao lhe privar das disposições sociais estabelecidas nas suas relações anteriores.

Clemmer (1958, p. 102) emprega o termo swallowing up para se referir ao sentimento de perda de identidade na primeira entrada do individuo na prisão. Esse sentimento é mais pronunciado nas pessoas não acentuadamente "criminalizadas" ou naquelas vindas de pequenas comunidades, aonde o anonimato não existe. Para Clemmer, alguns homens nunca conseguem superar os efeitos do processo de "ser tragado" pela instituição e parecem perder o sentido da sua própria individualidade.

Ao entrar na prisão, o individuo é obrigado a reconfigurar suas relações anteriores, enquanto pai, filho, profissional, amante, marido, vizinho etc. E passa a viver em uma sociedade na qual ele se relaciona com um número limitado de pessoas do mesmo sexo, quase da mesma faixa etária e, o mais grave, de maneira impositiva.

O comportamento do indivíduo em qualquer sociedade é determinado pelos padrões culturais, ou seja, por formas de aceitação social da conduta individual (Clemmer, 1958, p. 109). A diferença, para o individuo preso, está na influência da cultura prisional na constituição desses papéis e na própria interação social.

\footnotetext{
${ }^{39}$ Tanto o é que os presos usam a expressão "sair para a vida" se referindo a deixar a cadeia.
} 
Segundo Gofmann, os fatos na vida de uma pessoa compõem a sua identidade social, mas a maneira com que ela manipula esses fatos - explicitando, ocultando ou os negando - conforma a sua identidade pessoal.

"As normas relativas à identidade social referem-se aos tipos de repertórios de papéis ou perfis que consideramos que qualquer indivíduo pode sustentar 'personalidade social'... Normas relativas à identidade pessoal, entretanto pertencem não as esferas de combinações permissíveis de fatos sociais mas ao tipo de controle de informação que o individuo pode exercer com propriedade"

(Goffman, 1988, p.74)

O indivíduo preso ou que já cumpriu sua pena tem pouco controle sobre o conhecimento que as outras pessoas possam adquirir do seu estigma. Primeiro porque enquanto preso sua condição é explicita e inexorável, seja perante a equipe dirigente, os demais companheiros ou a própria família. E, depois, quando o indivíduo sai da prisão seja pela difusão da informação na sua comunidade, seja a partir da certidão de distribuição criminal exigida em qualquer tentativa de conseguir um emprego e reconstruir a vida, essa informação continua a ser retransmitida.

Por isso até muitos deles ao saírem da prisão passam a assumir a identidade de um amigo de aparência semelhante, o que os presos chamam de "dublê", de forma a se livrar do estigma atrelado à sua identidade verdadeira. O indivíduo cunhado com o estigma de presidiário tem pouca liberdade e poder sobre a sua identidade pessoal, a sua identidade social aparece antes e como limitante da pessoal.

Na análise de Clemmer $(1958,109)$ o comportamento individual à luz dos preceitos da cultura prisional determinará se as relações entre o preso e a instituição são positivas ou negativas, harmoniosas ou de embate.

A cultura prisional consiste nos hábitos, sistemas de comportamento, costumes, regras, idéias opiniões, concepções sobre a vida, a família, o trabalho, a prisão, a polícia, o amor etc 
compartilhados pelos indivíduos que habitam a prisão. É entendida por Clemmer (1958, p. 294), como uma força que conforma a atitude dos indivíduos; fruto da relação entre estrutura social (organização formal e informal da penitenciária) e o processo social (interação entre os detentos, e destes com aqueles que lá trabalham).

O grau de integração à cultura prisional varia de preso para preso, e, muitas vezes, a resposta pessoal dada às exigências institucionais às vezes choca-se com essa cultura. Todo preso rejeita algumas dessas regras e acata outras, ninguém aceita ou rejeita todas.

Para Clemmer (1958, p. 84) apesar da dinamicidade da prisão e do fluxo constante da sua população, os padrões mantêm-se essencialmente os mesmos. O paradoxo já existente na comunidade livre $^{40}$ da tendência em direção ao estabelecimento de controles e valores apesar das mudanças sociais é acentuado na vida prisional. Na prisão o modo de viver e os sistemas ${ }^{41}$ trabalho, disciplina, persistem a despeito das características dinâmica da vida e daqueles que a compõem

Gresham Sykes (2007), no capítulo 5 do seu famoso estudo sobre a New Jersey State Prison, publicado originariamente em 1958, constrói algumas bases para a compreensão da interação social nos estabelecimentos prisionais a partir da descrição de alguns padrões de comportamento seguido pelos presos.

O autor optou por descrever tais padrões a partir dos papéis sociais representados pelos presos, mais dos que pelos traços de personalidade dos mesmos, já que para ele o comportamento pode ser melhor entendido como sistemas de ação do que enquanto conjunto de características individuais (Sykes, 2007, p.106).

Apesar do padrão seguido pelo indivíduo poder sofrer variações, tanto temporalmente quanto espacialmente (um mesmo preso pode representar um papel na oficina de trabalho e outro

\footnotetext{
${ }^{40}$ Clemmer exemplifica essa permanencia com as instituições do casamento e da igreja que apesar de term passado por algumas mudanças ainda persistem enquanto instituiçoes

${ }^{41}$ sistema é utilizado para designar o modo como as coisas são feitas
} 
totalmente distinto no "raio" 42 , por exemplo), o que interessará a Sykes é a estrutura das relações sociais dos presos. Os diferentes modos de responder aos problemas advindos do emprisionamento, de forma a reduzir o rigor da vida prisional e perseguir objetivos próprios, permanecem mais ou menos constantes no dia-a-dia prisional.

O bem-estar na prisão depende menos do sucesso das atividades tidas como educação e recreação e mais de como o preso se relaciona com a ordem prisional, como ele gerencia sua vida na instituição e sua relação com outros detentos (Sykes, 2007, p.36)

\subsection{Estigma}

“... existe um mundo bem estabelecido de interações no qual a pessoa estigmatizada se acomoda, onde se cria um novo sistema de interação qualitativamente próximo ao da macrossociedade, talvez quantitativamente mais rígido”

(Cohen e Augustinis, 1998, p. 57)

Em toda sociedade há normas de identidade que definem os papeis dos indivíduos "normais” e dos estigmatizados. Estigma é definido por Goffman logo no início de seu ensaio de mesmo nome como a situação de impossibilidade de um indivíduo obter aceitação social plena (Goffman, 1988, p.7).

Segundo Goffman (1988) a palavra estigma surge na Grécia antiga como designação dos sinais feitos a corte ou fogo, para marcar o corpo dos traidores, escravos ou criminosos. A marca sinalizava que a pessoa possuía algo de ruim ou diferente no seu status moral e que, portanto, deveria ser evitada no convívio social. Na Era Cristã a palavra ganhou mais dois significados: primeiro como sinal da graça divina que assumia a forma de erupções sobre a pele, e em segundo, para designar algum distúrbio físico.

42 Pavilhão ou ala de uma prisão. 
Pode-se dizer que o estigma hoje tem origem em três fontes (Goffman, 1988) diferentes: a origem física (advinda de alguma deformidade corporal), a social (étnica, racial ou religiosa), e as culpas de caráter individual-moral (caso do preso ou do individuo viciado em drogas, por exemplo).

Para a compreensão e ordenação da realidade que nos cerca, nomeia-se, divide-se e categoriza-se o mundo, os objetos e as pessoas. A etiqueta tende a obscurecer outras características do individuo, reduzir sua complexidade. Deixa-se de considerá-lo enquanto ser humano como total e comum, para separá-lo, diferenciá-lo e aprisioná-lo na condição de portador do estigma.

O estigma funciona como uma lente pela qual são olhados certos tipos de pessoas, ao mesmo tempo em que a própria pessoa introjeta essa visão exterior. O indivíduo internaliza o estigma, criando expectativas, mecanismos de defesa e estabelecendo relações a partir dele, em um esforço de ocultá-lo, consertá-lo ou até mesmo aceitá-lo:

“Eu sempre sinto isto em relação a pessoas direitas: embora elas sejam boas e gentis, para mim, realmente no intimo, o tempo todo, estão apenas me vendo como criminoso e nada mais. Agora é muito tarde para que eu seja diferente do que eu sou, ainda sinto isso profundamente: que esse é o único modo de se aproximar de mim e que eles são absolutamente incapazes de aceitar outra coisa”.

(Parker e Allerton, 1962, apud Goffman, 1988, p.23)

Goffman (1988) divide os estigmatizados em dois tipos: desacreditados e desacreditáveis. Os primeiros são aqueles cujo estigma é evidente: logo no primeiro contato o indivíduo já perde um pouco do prestígio e da integridade: é desacreditado. Já nos desacreditáveis, o estigma não é evidente, cabendo à pessoa a manipulação dessa informação, ora revelando-a, ora ocultandoa. Por isso ele é desacreditável, e apenas potencialmente desacreditado (no caso da informação 
ser revelada). Esse jogo da escolha de quem e quando revelar o estigma se torna elemento constitutivo da personalidade do desacreditável.

As pessoas que têm um estigma específico tendem a ter semelhantes experiências no aprendizado da sua condição de estigmatizado e nas mudanças na concepção do eu, uma seqüência semelhante de ajustamentos pessoais (Goffman, 1988, p.41).

Porém não é fácil aceitar o outro estigmatizado como um igual, pois fazê-lo seria assumir a própria condição de estigmatizado que é alijado socialmente. Daí a tendência à construção de uma relação ambivalente entre os estigmatizados, que ora se identificam entre si ora se rejeitam:

“Cada preso pleiteava para si a definição de criminoso por acidente. O que era 'natural' na trajetória do (criminoso) nato seria uma espécie de anomalia na sua própria trajetória:

'Eu não saberia explicar assim mais detalhadamente sobre esse tipo de elemento. Pra mim se torna meio difícil justamente porque não estou dentro desse círculo de criminosos, desse tipo de criminoso. " "

(Ramalho, 2002, p. 110)

Pela abordagem interacionista da formação identitária, o fato social constitui o indivíduo. Logo, a visão dos outros passa a integrar a própria visão e conformar a identidade. É esse o ponto central do estigma (e mesmo da teoria do labelling approach): além do movimento externo dos outros imprimirem ao indivíduo certa etiqueta, é o fato de ele internalizá-la que trará sérias conseqüências à sua identidade. Pois ele passa a organizar sua vida e identidade a partir do estigma, causando mudanças na forma de ver e ser visto.

Para o individuo preso, a internalização da etiqueta criminoso terá três graves conseqüências: vulnerabilidade, criminalização secundária e identificação secundária, que serão tratadas no capítulo seguinte. 


\section{CAPÍTULO 3 \\ PROCESSO DE PRISIONIZAC̣ÃO E CONFORMAC̣ÃO IDENTITÁRIA}

"O desviado, como agente psicossocial presente na perspectiva da reação social é justamente aquele sujeito que organiza a sua identidade em torno da situação de deteriorização de sua personalidade. Assim, pode-se dizer que o processo de definição de criminalidade sustentado pelas instituições punitivas, como uma 'profecia que se auto-realiza', tem com principal efeito conformar, adequar, determinados indivíduos à imagem que deles possuíam tais instituições”

(Marteau, 1997, p. 100).

\subsection{Processo de prisionização}

O processo de prisionização consiste nos efeitos da prisão sobre a identidade do preso. Ao ingressar no sistema prisional, o indivíduo tem alteradas suas referências e relações anteriores, e deve absorver os novos padrões sociais existentes, adaptando-se rapidamente às regras da casa. A integração aos costumes, valores e normas comuns aos detentos se dá a partir do processo de socialização pelo qual o individuo se apropria dos códigos, da linguagem e dos conhecimentos específicos desse grupo social (cultura prisional).

Apesar de a prisionização agir sobre cada preso de modo distinto, todos são de alguma forma afetados pela cultura prisional. Ao vivenciar a experiência do encarceramento, os presos passam a compartilhar as frustrações e angústias da vida no cárcere e o desejo incansável pela liberdade, além de um modo de vida próprio à realidade prisional. A perda de antigas referências e assunção de novas corresponde a dois movimentos que são constituintes do processo de prisionização. 
Baratta (2002) vislumbra o processo de socialização ao qual o preso é submetido a partir de um duplo ponto de vista: o da “desculturação” e da “aculturação” (ou “prisionalização”) ${ }^{43}$. O primeiro é caracterizado pela desadaptação às condições necessárias para a vida em liberdade, enquanto o segundo pela assunção das atitudes, dos modelos de comportamento e dos valores característicos da subcultura carcerária ${ }^{44}$.

No presente trabalho, o processo de prisionização é visto como a síntese desses dois processos: um que nega e outro que afirma. Esses dois movimentos são complementares, pois enquanto a desculturação pode ser caracterizada por sua negatividade ao abalar as referências anteriores, a aculturação pode ser associada à positividade, na medida em que promove a construção de uma nova identidade do condenado, que, uma vez no sistema, é compelido a restabelecer novos parâmetros do eu.

“Como sabemos a dinâmica dos processos de socialização, naturalização e familiarização, permite aos indivíduos dentre outros aspectos, internalizar elementos, que caso não fossem tomado como naturais causariam de maneira contínua estranhamento e choques”.

(Moraes, 2005, p.222)

Para Sá (1998, p.120), o processo de prisionização tem como elemento central a desorganização da personalidade, caracterizada principalmente pelo empobrecimento psíquico, fruto da restrição dos horizontes individuais e sociais e dos processos de regressão e infantilização; pelos sentimentos de inferioridade e de impotência; e, ainda, pela "perda” de uma identidade e assunção de uma nova.

\footnotetext{
${ }^{43}$ Cabe ressaltar que Baratta denomina "prisionalização" apenas a parte positiva do processo (a absorção da cultura carcerária), enquanto nesse trabalho será utilizado o termo prisionização para se referir tanto às perdas quantos aos ganhos identitários.

${ }^{44}$ Para Clemmer (1958, p. 87) a cultura prisional corresponde às instituições e ao modo de vida que caracterizam os presos, tais como costumes, crenças, valores, conjunto de conhecimentos, moral, lei. A assimilação de uma cultura de determinada unidade social se dá, ainda que inconscientemente, a partir do processo de comunicação.
} 


\subsection{Poder repressor e desculturação}

Ao ingressar no sistema prisional ${ }^{45}$, o sentenciado é submetido a uma série de rituais de admissão, instante em que o homem começa a ser violentado. O nome, símbolo máximo da identidade, é substituído por um número; seu cabelo é raspado; suas roupas tornam-se largas, desajeitadas e iguais entre si; seus bens pessoais são recolhidos. O homem, despido de grande parte de sua individualidade, está apto a absorver uma nova cultura, vulnerável para que a instituição lhe impinja a sua disciplina.

O indivíduo preso perde parte de sua autonomia - a instituição determina o que deve fazer, quando e como; tem seu centro de vontade abalado - o controle das suas necessidades é feito pela instituição; é privado de contato com o mundo exterior - é criada uma tensão entre o mundo externo e o mundo institucional. Todas essas perdas contribuem para a infantilização do indivíduo e o enfraquecimento de suas concepções identitárias anteriores ao cárcere, pois, como visto no capitulo anterior, a identidade é processo: à medida que as relações que a conformavam mudam, ela própria se altera.

Dessa forma, o processo de desculturação, por sua negatividade, pode ser visto como manifestação do poder repressor. Porém, de acordo com a ótica foucaultiana, esse não é o exercício mais importante do poder: seu exercício mais importante é o disciplinar que, longe de ser uma instância de interdição, é caracterizado por sua produtividade.

Em Vigiar e Punir, Michel Foucault irá esmiuçar como o poder jurídico-político que regeu a sociedade ocidental até o séc. XVII, ligado às figuras dos monarcas e à economia punitiva dos suplícios, deu lugar a uma nova forma de poder. O poder disciplinar que se afirma no séc. XIX

\footnotetext{
${ }^{45}$ Conforme será analisado em seguida, com a mudança na configuração contemporânea da prisão (que passa a ter como fim a exclusão mais do que a correção e na qual o poder de controle passa a ser exercido ao lado do poder puramente disciplinar), a perda da autonomia do preso é relativa, uma vez que não importa tanto mais o que ele faz desde que seja mantido apartado e sob controle. No Brasil essa mudança fica evidente com a postura estatal de atribuir parte da administração do estabelecimento penal para os próprios presos e com o fortalecimento das facções criminosas dentro dos mesmos.
} 
como projeto de disciplinarização e normalização da vida, é caracterizado por sua positividade: sua principal função é produzir determinadas individualidades, adestrar os corpos para deles extrair uma utilidade.

A prisão representou a forma mais pura e explícita desse poder da sociedade disciplinar. Para Foucault (2004, p. 73), “o que é mais fascinante na prisão é que nelas o poder não se esconde”. Porém, esse poder não se limita aos muros do cárcere, nem se identifica com uma determinada estrutura social. Ele permeia as nossas relações atingindo todas as instâncias da vida (familiar, escolar, profissional, sexual), com o objetivo de corrigir o corpo e vigiar as mentes.

\subsection{A função do cárcere na dinâmica social e na dinâmica interna da prisão}

“O atestado que a prisão fracassa em reduzir crimes deve ser substituído pela hipótese de que a prisão conseguiu muito bem produzir a delinqüência, tipo especificado, forma política ou economicamente menos perigosa de ilegalidade”.

(Foucault, 1999, p.230)

A partir da ótica foucaultiana, poder-se-ia analisar as funções da prisão a partir de duas perspectivas: a primeira seria a função da prisão na dinâmica social enquanto gerenciadora de ilegalidades e produtora da delinqüência; a segunda seria dentro da própria dinâmica prisional, no exercício do poder sobre o indivíduo preso.

\section{A) Funcionalidade da prisão dentro da dinâmica social}

A funcionalidade do sistema de justiça criminal dentro da dinâmica social é gerenciar as ilegalidades (Foucault, 2002). Ele dissocia as ilegalidades: investe contra algumas delas um mecanismo punitivo - que na maioria dos casos toma a forma do encarceramento - enquanto 
legitima que outras sejam “toleradas" ou até mesmo "permitidas”, desde que controladas e rentáveis, tal como ocorre com o comércio ilegal de drogas.

Dessa forma, não é o poder repressor, oficial, exercido com a mediação do órgão judicial, o verdadeiro e real poder do sistema penal. Seu exercício mais importante e perigoso é o chamado poder configurador ou positivo do sistema penal, que, de acordo com Zaffaroni (1991), cumpre a função de disciplinamento verticalizante e é exercido à margem da legalidade, de forma arbitrariamente seletiva.

Por isso, não há de se falar em falência da pena de prisão. O atestado do fracasso no exercício de sua função de ressocialização data de seu nascimento, mais de 200 anos atrás. Porém, sua verdadeira função vem sendo exercida com sucesso desde sua criação (Foucault, 2002). O pretenso fracasso da prisão é constitutivo do seu próprio funcionamento.

O sistema de justiça penal exerce uma função produtiva, na medida em que gerencia as ilegalidades, diferenciando-as, selecionando-as, ocultando-as ou destacando-as; estabelecendo o que é tolerado ou não, o que é criminalizado o que não é, quem vai preso e quem não vai.

O trabalho de Georg Rusche e Otto Kirchheimer, Punição e Estrutura Social (publicado pela primeira vez em 1939), inaugura uma nova perspectiva de análise, ao despir a pena de seu viés ideológico e político, para que sua funcionalidade seja apreendida de modo concreto, a partir das condições econômicas e sociais de determinada época, atribuindo assim um caráter de historicidade à pena e ao próprio sentido da punição ${ }^{46}$ :

"A pena como tal não existe; existem somente sistemas de punição concretos e práticas penais específicas. O objeto de nossa investigação, portanto, é a pena em suas manifestações específicas, as causas de sua mudança e de seu

\footnotetext{
${ }^{46}$ Da mesma forma, Michel Foucault nunca pretendeu uma teoria geral do poder, mas se ocupou de suas manifestações concretas.
} 
desenvolvimento, as bases para a escolha de métodos penais específicos em períodos históricos também específicos”.

(Rusche e Kirchheimer, 2004, p.19,20)

A origem da instituição prisional como pena por excelência não pode ser dissociada do desenvolvimento do capitalismo. A pena quantificada em tempo de privação de liberdade só foi possível com a transformação do tempo em tempo de trabalho. A prisão moderna surge, justamente, para explorar a força de trabalho dos presos, e, principalmente, reinseri-los na moral e no meio de produção capitalista. A estreita relação da forma de produção com a função da prisão fica evidente na comparação da primeira forma de prisão com as casas de correção manufatureiras da época, feita por Rusche e Kirchheimer (2004, p.99).

A criação da categoria do delinqüente, e mesmo do louco ou vagabundo (os quais se opunham moralmente e economicamente à categoria do trabalhador ${ }^{47}$ ), colocando-os fora do padrão de normalidade e longe da aceitação social, objetivava reprimir a tolerância e simpatia da população pelas ilegalidades indesejadas e atitudes contraproducentes. ${ }^{48}$

Os mecanismos de poder que agiam na dinâmica social, e particularmente na rotina carcerária, estavam alinhados com a ética do trabalho e o modo de produção capitalista, com o intuito de disciplinar o indisciplinado e dele extrair a força de trabalho que impulsionaria a economia.

Nesse sentido, a prisão intimidaria, à medida que as condições de vida oferecidas no cárcere eram inferiores às do trabalhador livre de mais baixa categoria, de modo que ainda o pior dos trabalhos seja mais vantajoso do que a permanência na prisão.

\footnotetext{
${ }^{47}$ Conforme atesta José Ricardo Ramalho, em O mundo do crime; a ordem pelo avesso (2002), essa oposição atravessou o séç. XX. Nessa obra, fruto de pesquisa realizada em meados dos anos 70 na Casa de Detenção de São Paulo, Ramalho descreve a cisão entre o mundo do crime e o mundo do trabalho a partir da lógica dos próprios presos.

${ }^{48}$ Ilegalidades que iam contra aos princípios do capitalismo industrial e à necessidade crescente de mão de obra, característicos do período em questão.
} 


\section{B) Funcionalidade da prisão na dinâmica prisional: a função penitenciária}

"Desarticular a personalidade do preso é o primeiro - e, talvez o mais importante - papel do sistema."

(Lima, 2001, p.44)

A instituição disciplinar, no tocante à função exercida dentro da sua própria dinâmica interna, funciona no sentido de produzir o homem delinqüente, a partir de mecanismos como o controle e o exame. O indivíduo entra na prisão infrator e sai dela delinqüente (Foucault, 2002, p. 230). Foucault já alertava de que, ao contrário do que geralmente se atesta, a função mais perigosa do sistema de controle não é a repressora (que anula, nega e cala), mas a que ele chamará configuradora (que molda, afirma, e faz falar).

O poder repressor, dentro da dinâmica prisional, pode ser associado ao processo de desculturação, enquanto o poder configurador está relacionado ao processo de aculturação à medida que, mais do que conter e oprimir ações, ele condiciona e molda o indivíduo. O poder positivo adestra, através das disciplinas e respaldado por um saber.

Qualquer manifestação do indivíduo que se distancie da expectativa institucional é deslegitimada pela organização, e, independentemente de como o indivíduo responde às exigências prisionais, ele sempre estará errado. Goffman denominou esse processo circuito, o qual se traduziria em uma agência responsável por criar uma resposta defensiva do condenado ao mesmo tempo em que o ataca por ela: "a reação do internado à sua situação é levada de volta à situação" (Goffman, 1974, p.41).

O circuito constitui uma forma indireta de mortificação, um mecanismo cruel que desqualifica e desconfirma a comunicação do preso, retirando sua espontaneidade e comprometendo qualquer possibilidade de manifestação autêntica. Ainda que ele responda conforme a instituição espera, a sua reposta é deslegitimada e utilizada contra ele: "se correr o bicho pega se ficar o bicho come". 
A descrição de Epstein sob a perspectiva da comunicação social, assim como a fala de um adolescente interno da Febem ${ }^{49}$ reproduzida na pesquisa de Vicentin, ajudam a esclarecer e ilustrar a idéia de circuito:

"Essa resposta defensiva do paciente às ordens que ultrajam a sua concepção do próprio eu e que, em situações normais consistiria em expressões de mau humor, palavrões, ironia ou sarcasmo, é por sua vez punida, nas instituições totais com novos castigos. Essa prática do circuito equivale em invalidar a comunicação do paciente ou mesmo puni-lo, por sua tentativa de utilizar uma resposta equívoca (ironia, sarcasmo) a mensagens unívocas (ordens ultrajantes)”

(Epstein, 1990, p. 193)

"Se a gente tenta falar o que está certo ou o que está errado, a gente já pode ir pro bonde... para eles, nóis nunca está certo! Aí nóis vai ter que seguir a doutrina deles".

(Vicentin, 2005, p. 79)

Goffman (1974) descreve o novato no sistema como um objeto a serviço da máquina administrativa, modelado suavemente pelas operações de rotina. Tais operações, que agem sobre o espaço, as atividades, o tempo e as forças, são as minúsculas invenções técnicas que Foucault (2004) denominou micropoderes, pequenas disciplinas que subordinam os corpos e as forças a utilidade do poder. Uma aparelhagem para tornar os indivíduos dóceis e úteis, através de um trabalho preciso sobre o seu corpo e mente.

"O mecanismo das tecnologias disciplinares se traduz por uma apropriação daquilo que o indivíduo produz, dos saberes, sentidos e hábitos a ele

\footnotetext{
${ }^{49}$ Fundação Estadual do Bem-Estar do Menor, hoje denominada Fundação Centro de Atendimento SócioEducativo ao Adolescente (CASA).
} 
relacionados... Tal apropriação incide sobre a constituição do sujeito, de forma a não necessitar subjugar e impor, mas apenas dar meios e instigar a sua ação".

(Fonseca, 2003, p. 51)

Nesse sentido, a incidência do poder disciplinar no corpo e alma do indivíduo traz grandes conseqüências à sua identidade. Para Foucault, ao inserir uma produtividade, reformando e produzindo individualidades, a prisão exerce o que ele chama de função penitenciária ${ }^{50}$, que representa um excesso em relação à sua função jurídica (prisão enquanto detenção) e que garante o sucesso da prisão como punição .

O poder penitenciário, antes de ser um projeto ou uma ciência, é "uma técnica que se aprende, se transmite, e que obedece a normas gerais" (Foucault, 2002, p. 245) no sentido de normalizar, a partir do controle e da vigilância, qualquer individuo que mantenha um comportamento alijado dos padrões de normalidade e moralidade.

O modelo de justiça se concretiza nas inúmeras instituições disciplinares, das quais a prisão se apresenta na sua forma mais pura. A partir da continuidade carcerária (da expansão da rede carcerária para além dos espaços prisionais), a prisão se torna mais uma peça na nova economia de poder, que objetiva curar, educar, corrigir, recalcar. A prisão interliga dois registros: o legal da justiça e o extra-legal da disciplina, o poder carcerário se situa entre o poder disciplinar e o legal:

"O carcerário naturaliza o poder legal de punir, como legaliza o poder técnico de disciplinar. Homogeneizando-os assim, apagando o que pode haver de violento em um e ilegal no outro".

(Foucault, 2002, p. 250)

\footnotetext{
${ }^{50}$ Chamado por Foucault também de poder carcerário. O “Carcerário” deu título ao último capítulo de Vigiar e Punir, localizado na $4^{\mathrm{a}}$ parte do livro denominada Prisão (Foucault, 2002, p. 243-254).
} 
O exercício do poder disciplinar na dinâmica prisional, através de mecanismos que impingem ao indivíduo preso uma identidade secundária, deteriorada, estigmatizada, é condição da manutenção do sistema punitivo, à medida que é a vulnerabilidade que eles produzem que realimentará a seletividade do sistema de controle:

"A partir do momento em que alguém entrava na prisão, ajustava-se um mecanismo que o tornava infame; e quando ele saía, não podia fazer nada diferente do que voltar a ser delinqüente”

(Foucault, 2006, p.163)

C) As mudanças no fim do séc. XX: do poder disciplinar ao poder de controle

O poder disciplinar insere-se em uma nova economia da punição, uma vez que o poder soberano, centrado na figura do rei que decidia acerca da vida e da morte de seus súditos, se tornou incompatível com a complexidade da racionalidade moderna. Com as sociedades disciplinares, o objeto de punição deixa de ser o corpo e passa a ser a alma, e a violência explícita dos suplícios é substituída pela a violência velada do cárcere. Entra em cena um poder que produz antes que destrua, formata mais do que reprime (Foucault, 2002).

O objetivo das chamadas instituições de seqüestro ${ }^{51}$ - nas quais se incluía a prisão - não era simplesmente excluir o indivíduo, mas de normalizá-lo, incluí-lo em um sistema disciplinar com o fim de torná-lo dócil, e dele extrair máxima utilidade. Tomam a existência temporal e espacial, pra esquadrinhá-lo em um lugar e tempo específicos:

"essas instituições - pedagógicas, médicas, penais ou industriais - têm a propriedade muito curiosa de emplacarem o controle, a responsabilidade sobre a totalidade, ou quase totalidade do tempo dos indivíduos; são, portanto,

${ }^{51}$ São as fábricas, hospitais, conventos, escolas, descritos por Foucault em a Verdade e as formas jurídicas (2003) e que deram nome à obra de Erving Goffman: Asylums (na edição brasileira Manicômios, Prisões e Conventos ). 
instituições que, de certa forma, se encarregavam de toda a dimensão temporal da vida dos indivíduos”

(Foucault, 2003, p.115)

Porém o poder disciplinar não era exercido só nas instituições de seqüestro, mas estendia-se por toda vida social, de forma capilar, descentralizada, múltipla, permeando as relações sociais, cuidando da regulação da vida como um todo e transformando o tempo em tempo útil. A expansão da técnica da instituição penal a toda sociedade, com a criação de diversos mecanismos disciplinares de punição de controle, conformou o que Foucault (2002, p. 247) denominou arquipélago carcerário.

Hoje, esses meios de confinamento passam por uma crise generalizada, o que não significa, necessariamente, seu fim, mas uma mudança no alcance e na própria forma do exercício de poder (Deleuze, 1992, p. 220). O controle total que vinha sendo feito de forma concentrada em alguns espaços e direcionado a alguns indivíduos expande-se para o exterior dessas instituições e alcança a população como um todo, indiscriminadamente.

Deleuze (1992, p.221) afirma a substituição da sociedade disciplinar pela de controle a partir, principalmente, da flexibilização da forma de sujeição do indivíduo ao poder. Enquanto o confinamento em espaços fechados eram moldes rígidos e fixos, os controles assumem a forma de modulação, cujo exercício é feito a partir de movimentos ondulatório que atingem todo o corpo social.

No mundo pós-moderno, todas as pessoas a todo o tempo estão sujeitas à ação contínua dos mecanismos de visibilidade, e às mais diversas formas de registro da sua existência (Moura, 2007, p.60). Os espaços de interação social são vigiados e o conteúdo dessa interação registrado: o conteúdo da comunicação feita por e-mail, blogs, espaços de bate papo virtual etc., é escrito e gravado; a popularização do uso dos cartões nas transações comerciais permite o detalhamento de como e onde o indivíduo emprega seu dinheiro; a disseminação de câmeras nos espaços públicos e privados faz com que o indivíduo tenha que sorrir a todo tempo porque pode estar sendo filmado. 
Como será visto adiante, os reflexos dessa mudança atingirão a própria racionalidade penal, com implicações na concepção da função da pena e na execução da mesma. A disciplina, que vigiava e conformava todos os atos da vida do condenado, passa a dar lugar ao controle, que longe de querer conformar sua existência, age no sentido de excluí-la. Os regimes de isolamento rígido e a propagação do controle para além dos muros institucionais, como, por exemplo, através do uso de pulseiras eletrônicas, podem ser tidos como manifestações dessa nova dinâmica do poder.

\subsection{Vulnerabilidade e identificação secundária}

"O estabelecimento prisional altera as tendências auto-reguladoras do internado, o qual precisará expor novos tipos de concepções e sentimentos sobre o eu".

(Goffman, 1974, p. 31)

O termo vulnerabilidade está associado à exposição e à susceptibilidade das pessoas a determinados riscos. A chamada vulnerabilidade psico-social é conseqüência da origem social desprivilegiada, da posição desprestigiada no mercado de trabalho, e das especificidades do processo de socialização do indivíduo (dentro da família, na escola ou mesmo da prisão). Dentre os riscos que envolvem esse tipo de vulnerabilidade estão o desemprego, a desestabilidade familiar, a marginalidade, e conseqüentemente, o encarceramento.

A vulnerabilidade individual é proporcional ao risco de ser selecionado pelas agências do sistema de controle: quanto mais vulnerável, maior a chance de incriminação pelo sistema de justiça criminal. Os fatores que levam à vulnerabilidade podem ser de dois tipos: aqueles ligados à condição sócio-econômica do indivíduo e, portanto, exteriores à sua vontade; e aqueles ligados à conduta individual, a auto-colocação em risco a partir de determinados comportamentos, dentre eles a realização do injusto (Zaffaroni, 2001, p.270). 
Os indivíduos mais vulneráveis e inseguros são mais suscetíveis à invasão institucional, pois não têm a identidade fortalecida, e, muito menos dispõem de meios para a sua preservação.

"Os sujeitos mais sensíveis às demandas do papel formuladas pelas agências dos sistemas penais, são os mais imaturos... A maior sensibilidade às demandas do papel relaciona-se diretamente com a possibilidade de invasão que o indivíduo ofereça”.

(Zaffaroni, 1991, p.134)

Ademais, pode-se diferenciar a vulnerabilidade que antecede à intervenção penal, ligada a precariedade do acesso aos direitos sociais básicos, da vulnerabilidade que a sucede, que é conseqüência do processo de prisionização. Tanto uma como outra irão deixar o indivíduo desprotegido da ação do sistema criminal. Porém, enquanto a primeira está ligada à desviação primária, a segunda ajuda-nos a compreender a desviação secundária, ou seja, a reinserção no sistema penal do indivíduo reincidente, que já passou por uma condenação anterior.

Silva (1998) ao analisar a influência do processo de institucionalização na formação identitária das crianças órfãs e abandonadas, responsabiliza o Estado pela construção de um tipo de subjetividade, que na maioria das vezes, será responsável por fixar o indivíduo em uma identidade delinqüente:

“... no ciclo de formação da criminalidade, criou-se, consolidou-se e autonomizou-se uma pedagogia do crime, que foi reforçada e estimulada pelas ações e omissões da instituição e dos agentes institucionais. A 'disposição natural', nesse contexto, pode ser entendida como a fragilidade $e$ vulnerabilidade do quadro referencial que a criança precisou apegar-se...”

(Silva, 1998, p. 143) 
É essa vulnerabilidade, ocasionada tanto por fatores sociais quanto individuais, que leva o indivíduo a ser selecionado pelo sistema de controle, que é estruturalmente seletivo e reprodutor das relações sociais. Nas precisas palavras de Zaffaroni:

"Os órgãos do sistema penal selecionam de acordo com estereótipos, atribuindo-lhes e exigindo-lhes [dos presos] esses comportamentos, tratandoos como se comportassem dessa maneira olhando-os, $e$ instigando todos a olhá-los do mesmo modo, até que se obtém, finalmente, a resposta adequada ao papel assinalado"

(Zaffaroni, 1991, p.133)

Em oposição ao conceito de vulnerabilidade, pode-se colocar o conceito de sofisticação elaborado por Turk ${ }^{52}$. Para o sociólogo americano, a sofisticação constitui na capacidade de conhecer a conduta dos atores do sistema de controle e de manipular a própria conduta a partir desse conhecimento, de forma a dificultar a criminalização.

"A sofisticação dos sujeitos significa que estes serão mais cuidadosos em avaliar a força ou fraqueza de sua oposição em relação às autoridades e que conseqüentemente, estarão com maior capacidade para evitar a guerra aberta com elas sem fazer concessões significativas (...) O conflito é mais provável quanto menos sofisticados os sujeitos".

(Castro, 1983, p.116)

Quanto mais estigmatizado o indivíduo, menos liberdade de manipulação de sua conduta ele tem, e, conseqüentemente, menos sofisticado ele será perante o sistema de controle, com maior chance de ser criminalizado.

\footnotetext{
${ }^{52}$ Turk, A (1969). Criminality and Legal Order, USA, Rand Mc Nally Sociology Series, apud Castro (1983, p.115).
} 
Uma vez criminalizado, quanto mais vulnerável o indivíduo, maior será a chance de interiorizar a cultura carcerária. Quanto mais a internaliza, mais ela conformará o processo identitário, estigmatizando-o e dificultando sua reinserção na cultura da sociedade mais ampla. A adaptação ao mundo livre exigirá do preso que ele reveja os valores e as atitudes apreendidas no cárcere, já que, não raramente, a cultura prisional se choca com os padrões estabelecidos pela sociedade.

“...os grupos considerados marginais que, embora compartilhem signos com a sociedade mais ampla, são os que nela mais se destoam em decorrência do modo com o qual se apropriam de seus valores”.

(Biondi , 2006, p. 5)

A esse processo de nova conformação identitária do desviante, a partir do efeito da aplicação da etiqueta de criminoso (processo chamado por Zaffaroni de desvio secundário), será dado o nome de identificação secundária.

A maneira pela qual o indivíduo se relaciona com seu eu civil ${ }^{53}$ está intrinsecamente relacionada à forma com que ele lida com as regras e imposições institucionais, assim como à forma pela qual ele será visto pelos outros atores prisionais (presos, agentes, equipe técnica, diretoria).

Pois, conforme visto no capítulo anterior, a percepção que se tem sobre si mesmo é atualizada e revisitada diariamente por meio das interações. A partir dos seus mecanismos de controle, a instituição leva à mortificação do eu (da identidade primária do individuo), ao mesmo tempo em que prende o indivíduo a outra subjetividade, estruturada em torno da desviação (identidade secundária).

Para Zaffaroni, a vulnerabilidade causada pela condenação do indivíduo (desviação primária) o torna mais suscetível a ser selecionado de novo pelo sistema penal (desviação secundária).

\footnotetext{
${ }^{53}$ Entende-se por eu civil a parte da identidade do indivíduo que resiste ao processo de institucionalização, a qual será denominada também identidade primária.
} 
A instituição realimenta o sistema de controle, na medida em que fixa a identidade dos indivíduos selecionados no cumprimento de determinados papéis, os quais pressupõem a reprodução de determinados comportamentos passíveis de serem criminalizados.

Quanto menos resistência o indivíduo tiver, mais facilmente as agências do sistema de controle poderão agir. Quanto mais enfraquecida a sua identidade primaria, maior a chance do indivíduo desenvolver uma identidade secundária, estigmatizada, que por sua vez vai facilitar a criminalização secundária e o recomeço do ciclo:

desviação primária $\rightarrow$ criminalização $\rightarrow$ processo de prisionização $\rightarrow$ identidade secundária/ estigma $\rightarrow$ desviação secundária $\rightarrow$ criminalização.

\subsection{Ajustamentos do indivíduo às regras institucionais}

"Sempre que se impõem mundos, se criam submundos"

(Goffman,1974, p. 246.)

Goffman (1974) utiliza o termo ajustamento para se referir ao modo como o indivíduo se relaciona com as regras institucionais (ainda quando sua atitude esteja em contraposição com as mesmas) $)^{54}$ e o divide em dois tipos: primário e secundário, e este último em dois subtipos: secundário contido e perturbador.

O ajustamento primário é caracterizado pelo respeito às regras da instituição, e sua "adequação" às exigências institucionais. O preso, ao contribuir para a estabilidade da instituição, respeitando suas regras, obedecendo a suas ordens, e principalmente, cumprindo o papel que lhe foi incumbido, torna-se o chamado participante normal, programado ou interiorizado do sistema, o bom preso.

${ }^{54}$ Para Sykes (2007, p.102) o comportamento do preso oscila entre a rebelião e o ajustamento. 
"Fica agora evidente, a natureza do 'bom ajustamento'. Ele exige que o estigmatizado se aceite, alegre e inconscientemente, como igual aos normais (não estigmatizados) enquanto, ao mesmo tempo, se retire voluntariamente daquelas situações que os normais considerariam difícil manter uma aceitação semelhante."

(Goffman, 1988, p. 132)

Clemmer (1958, p.86), por sua vez, denominará acomodação esse tipo de comportamento adaptativo do preso. A acomodação consiste no processo de ajustamento entre as partes do conflito, seja por consentimento mútuo, seja pela imposição de um poder superior.

Já o ajustamento secundário consiste em práticas que rompem com as regras oficiais da instituição, com o objetivo de que seus internos "consigam satisfações proibidas, ou obtenham, por meios proibidos, as satisfações permitidas” (Goffman, 1974, p. 54). São, portanto, inovações nas formas tradicionais de conseguir determinados bens ou direitos, tais como visita, trabalho, progressão de regime, melhor alimentação; ou ainda, meios para se obter certas vantagens proibidas (droga, celular, trânsito livre etc.).

Os ajustamentos secundários diferem entre si, principalmente, no tocante à sua finalidade: com os perturbadores, os indivíduos visam abalar a estrutura institucional, enquanto com os contidos desejam apenas "tirar melhor a cadeia" ${ }^{55}$. Ao praticar o primeiro, o internado passa a disputar o poder com a organização prisional. Já a prática do segundo está em harmonia com o poder estabelecido, pois, apesar de tal comportamento aparentemente ir contra a ordem institucional, ele é absorvido pela mesma, encaixa-se na estrutura institucional existente, tal como os primários ${ }^{56}$.

\footnotetext{
55 “Tirar a cadeia” é uma expressão, comumente, utilizada pelos presos para se referirem ao cumprimento da pena.

${ }^{56}$ Nesse sentido questiona-se quanto à possibilidade de um indivíduo recorrer exclusivamente aos ajustamentos primários durante sua vida institucional, justamente por ser improvável que uma instituição prisional (ou qualquer outra instituição) seja regida unicamente por seu regramento oficial. Sempre são criadas regras extraoficiais tacitamente acordadas entre os membros das instituições, de forma a relativizar a rigidez das regras oficiais. Logo, sob essa perspectiva, poderia-se qualificar como bom preso tanto os que estabelecem ajustes primários, quanto ajustes secundários contidos em relação ao sistema prisional, visto que em ambos os casos eles estão "dentro das regras do jogo".
} 
Fazendo um paralelo com os modelos de adaptação individual criados por Merton ${ }^{57}$, o ajustado contido corresponderia à forma de adequação individual do tipo inovador; porém, aqui, os meios ilegítimos são absorvidos pela própria instituição. Ao passo que o perturbador corresponderia ao modelo da rebelião, uma vez que se caracteriza pela negação tanto dos fins culturais quanto dos meios institucionais.

A prática do ajustamento secundário contido pode ser verificada nas mais diversas esferas da vida social: a traição dentro do casamento, o funcionário que lê revistas durante seu horário de trabalho, os servidores que fazem uso de bens públicos para uso pessoal; e, pode-se citar, na realidade prisional brasileira, o uso do cigarro como moeda de troca ou o consumo indiscriminado da maconha pelos internos nos presídios.

Trata-se de práticas ilícitas, não autorizadas formalmente, mas que são comportadas pela estrutura oficial, não representando uma ameaça ao sistema como um todo; pelo contrário, na medida em que passam a fazer parte do seu próprio funcionamento, são absorvidas por ele e se tornam necessárias à manutenção de seu equilíbrio.

Os ajustamentos secundário de tipo contido têm como fim a melhoria nas condições de vida do próprio interno, seu bem estar na instituição ou a conquista de uma regalia, e não se contrapõem ao processo de prisionização, mas o constituem; os ajustamentos denominados perturbadores por Goffman podem constituir uma tentativa de preservação da identidade primária, descolada da identidade institucional.

Os ajustados secundários perturbadores diferem dos demais quanto às respostas dadas ao sistema. Enquanto os ajustados primários e os contidos confirmam e reforçam a ordem posta,

${ }^{57}$ Segundo a teoria funcionalista da anomia de Merton (1957, p.162) o desvio é um produto da estrutura social, resultante da contradição entre estrutura social e cultura: não há disponibilidade de meios legítimos para se alcançar os fins valorizados culturalmente. Desta desproporção surge o comportamento desviante. Do concurso entre fins culturais e meios legítimos, Merton (1957, p.129-157) cria cinco modelos de adaptação individual: conformidade, inovação, ritualismo, apatia e rebelião. A conduta desviante típica corresponderia ao modelo de adequação individual inovador, no qual o indivíduo adere aos fins culturais, mas não aos meios institucionais. Sendo que, depois de preso, o inovador, se ajustado primário, pode vir a assumir a postura de conformidade (aceitar tanto os fins culturais quanto os meios institucionais da prisão), manter-se inovador ou "rebelar-se”. 
os secundários tentam romper com as regras institucionais e com as expectativas quanto à sua conduta. Ao proporem novos valores, desafiam a estabilidade da instituição.

Para Goffman pode ser estabelecida uma estreita ligação entre o ajustamento secundário perturbador e a necessidade da preservação do eu civil. Ao não se sujeitar ao status que lhe é impingido e às funções que lhe são atribuídas, o indivíduo começa a estabelecer os limites entre ele e a unidade social que lhe cerca. O rompimento com os valores institucionais é uma forma de preservar os valores que lhe são próprios.

“Ajustamentos secundários são para o internado uma prova de que ele ainda é um homem autônomo, com certo controle de seu ambiente, quase uma forma de abrigo para o eu. Nosso status se apóia nas construções sólidas do mundo, enquanto nosso sentimento de identidade pessoal reside, freqüentemente, em suas fendas”.

(Goffman, 1974, p.259)

O mundo institucional retratado na obra de Goffman possui pouquíssimas fendas, já que todos os atos são controlados pela direção e não há espaço para diferenças e manifestações individuais. Logo, para o autor, o indivíduo passa a se identificar pelo seu status de internado; a identidade institucional, construída a partir de mecanismos de resistência e de sobrevivência em um ambiente estranho e hostil, prevalece: em função desta identidade ele é reconhecido, cobrado e julgado. A partir daí, estabelece-se o estigma e o sentimento de inferioridade, conjunto este que determinará o seu papel no mundo institucional e no submundo da criminalidade.

\subsection{Relativização da totalidade das instituições prisionais na contemporaneidade}

Goffman (1974, p. 16) descreve que toda instituição tem tendência ao fechamento, mas o caráter total de algumas delas pressupõe um fechamento maior ainda, advindo das barreiras entre elas e o mundo externo, incluindo a proibição de saída. 
A totalidade enquanto característica intrínseca da prisão deve ser relativizada a partir da observação dos estabelecimentos prisionais contemporâneos ${ }^{58}$. Diferente da instituição manicomial etnografada por Erving Goffman em 1955/1956 (Goffman,1974), ou mesmo do que ocorria duas décadas atrás nos presídios brasileiros, hoje o caráter totalitário dessas instituições deve ser revisto devido principalmente a três fatores: A) abertura de novos canais de comunicação; B) mudança na configuração dos dois grupos (dirigidos e dirigentes); C) mudança no discurso da funcionalidade da pena.

\section{A) A abertura de novos canais de comunicação no interior da instituição;}

A instituição total é caracterizada por uma aguda restrição na comunicação, seja em relação à comunicação interna (entre os presos e destes com a direção), seja em relação à externa, pelo isolamento do mundo prisional em relação ao mundo exterior.

Apesar de hoje ainda haver sérias restrições no sentido de calar e isolar o preso, elas se enfraqueceram na atual dinâmica prisional ${ }^{59}$. O crescimento do poderio das facções criminosas no interior das unidades prisionais permitiu uma maior fluidez na comunicação interna; a partir do reconhecimento institucional de seus líderes (chamados pilotos ou faxinas), que ao conquistarem maior liberdade de movimentação, permitiram que as informações, mercadorias e ordens passassem a circular mais e de forma mais eficiente.

Além dos mais, o incremento no intercâmbio de informações entre o cárcere e o “mundão”, por meio da abertura de canais alternativos de comunicação - principalmente do telefone celular e do trabalho específico de alguns advogados - levou a uma inevitável abertura da instituição prisional em relação à sociedade, na medida em que a dinâmica prisional passa a influenciar e ser influenciada mediatamente pelo o que ocorre na sociedade além das grades.

\footnotetext{
${ }^{58} \mathrm{E}$ é justamente a permeabilidade das instituições prisionais hoje que permitiu o fortalecimento das facções criminosas dentro dos presídios brasileiros. Essa discussão, caríssima à esta pesquisa, será retomada no capítulo que segue a este.

${ }^{59}$ Excetua-se nessa análise os estabelecimentos de segurança máxima - tais como os sob Regime Disciplinar Diferenciado (RDD), introduzido pela Lei 10.792/2003.
} 
A disseminação do uso de celulares nos presídios ${ }^{60}$ possibilitou aos presos gerenciar seus negócios e até cometer crimes de dentro da prisão; comunicar-se diretamente com suas famílias, amigos e com detentos de outras unidades prisionais, e inclusive conhecer pretensas namoradas $^{61}$.

A atuação de alguns advogados foi outro agente propulsor da intensificação do contato dos presos com o exterior dos presídios, principalmente como intermediador da comunicação entre indivíduos que estavam em diferentes estabelecimentos prisionais. É atribuído ao trabalho de alguns advogados o sucesso na organização de rebeliões nos presídios do interior do Estado de São Paulo. Tal suspeita resultou em denúncia oferecida pelo Ministério Público em 2006 na $13^{\mathrm{a}}$ Vara Criminal da Capital contra três advogados acusados de envolvimento com uma facção criminosa.

A Constituição Federal (art. 136, § $2^{\circ}$, inciso IV) veda a incomunicabilidade do preso, ainda que durante a vigência do Estado de Defesa e o art. $7^{\circ}$, III do Estatuto da OAB (Lei $n^{\circ}$ 8906/94), garante ao preso a sua comunicabilidade com seu advogado: é direito do advogado “comunicar-se com seus clientes, pessoal e reservadamente, mesmo sem procuração, quando estes se acharem presos, detidos ou recolhidos em estabelecimentos civis ou militares, ainda que considerados incomunicáveis”.

Logo, o advogado é muitas vezes o único que pode ter acesso ao preso que está sob regime de segurança máxima. Nesses casos, ele passa a desempenhar um papel fundamental na continuidade da comunicação deste preso com os demais presos e com outras pessoas em liberdade, ao consultar seu cliente não com o objetivo de assessorá-lo juridicamente, mas, exclusivamente, de exercer a função de pombo-correio.

\footnotetext{
${ }^{60} \mathrm{O}$ telefone celular chegou ao Brasil no inicio dos anos 90 . O seu uso nos presídios paulistas foi deflagrado com a megarrebelião de 2001, cuja complexa organização só foi possível por intermédio da telefonia celular.

${ }^{61}$ Em uma conversa em 2007, alguns presos me revelaram que conhecem meninas em chats (espaço de batepapos na internet que podem ser realizados a partir de celulares), que passaram a visitá-los na prisão, tornando-se suas namoradas.
} 


\section{B) Mudança na configuração dos dois grupos (dirigidos e dirigentes)}

Outra característica da instituição total (Goffman, 1974) é que ela é composta por dois grupos, dirigidos e dirigentes. O primeiro é mais numeroso, formado pelos internos, e o segundo, menor, formado pelos dirigentes e demais funcionários. Entre os últimos são atribuídos papéis claramente delimitados: o grupo dos internos é dirigido enquanto o grupo dirigente dirige.

Contudo, com o gerenciamento dos estabelecimentos prisionais por parte da Administração (Fisher, 1989), que delega parte de seu poder aos próprios presos, o grupo dos internos ganha autonomia em relação à equipe dirigente e acaba ele mesmo sendo responsável pela organização e controle de parte da dinâmica prisional.

Logo, merece ser repensado o caráter total da instituição descrita no texto de Goffman, detentora do monopólio da organização da vida do interno, pressupondo perda da autonomia e completa submissão deste à vontade da equipe dirigente.

\section{C) Mudança no discurso da funcionalidade da pena.}

“A verdade é que o sonho, que via na prisão o instrumento ideal para cumprir esse duplo fim (punir e educar para a liberdade), acabou”

(Pimentel, 1983, p. 130)

"No wonder, therefore, that idea of prison sentence as simultaneously the most effective method of disempowering the potentially harmful people and a most painful retribution for ill deeds...”

(Bauman, 2000, p. 39) 
Já em 1983 Manuel Pedro Pimentel afirmava categoricamente a necessidade de abandonar o mito ressocializador e assumir que a prisão só serve para punir, cumprindo sua função retributiva (Pimentel, 1983, p. 184).

O discurso utópico da ressocialização vem sendo aos poucos substituído por outro mais duro e realista, que assume a prisão como castigo, cuja função é tão somente "neutralizar o delinqüente”. A prisão despe-se de sua pretensão reformadora, para se assumir enquanto instituição de controle e dominação.

O mito da sociedade moderna de que o Estado proverá a segurança e a ordem está em derrocada. As declarações do Estado no campo da repressão criminal se tornaram mais modestas e mais hesitantes (Garland, 1999, p. 62).

A prisão não é mais escola pra nada, é a disciplina formal e pura, o laboratório da sociedade globalizada (Bauman, 2000, p.32). Não importa o que os presos fazem dentro de suas celas, desde que permaneça excluído. Só o fato de não se mover ou não se falar em uma sociedade tão volátil (a qual Bauman dá o nome de líquida) é o maior símbolo de incapacidade e impotência, além de consagrar a exclusão e a limpeza do outro, do que é diferente e se teme.

Bauman (2000, p.28) ilustra essa mudança com o exemplo de Pelican Bay - prisão situada na Califórnia na qual os presos não têm contato cara-a-cara com os guardas ou outros presos, ficam em suas selas, não vêem e não são vistos, incomunicáveis. Mas antes de considerá-la como uma versão "high-tech” do panóptico de Bentham, Bauman nos chama para uma análise mais depurada.

Hoje, as prisões em muito se distanciam da reforma ética que as instituições panópticas queriam promover. A função do panóptico, e dos mecanismos disciplinares em geral, consistia em reenquadrar o individuo nos padrões sociais, reinserindo-o na ética do trabalho. Contudo com a nova configuração econômica e social da pós-modernidade, caracterizada pelo desemprego, excesso de mão de obra e flexibilização das relações de trabalho, a imposição dos comandos éticos do trabalho perdeu o sentido. 
A aceitação da ética do trabalho não é mais condição para a reinserção social do preso, já que não há demanda social por mão de obra, não há necessidade de que o preso (ao sair da instituição ou ainda dentro dela) esteja docilizado para o trabalho. Por isso, hoje, a Pelican Bay e as prisões em geral, apesar do alto nível de controle que exercem sobre o individuo, não têm mais a pretensão de reformá-lo, distanciando-se assim do fim da vigilância onipresente da instituição panóptica.

À medida que o discurso constitui o objeto ao qual se refere, a mudança no discurso da funcionalidade da pena vai trazer conseqüências práticas à dinâmica prisional, inclusive quanto ao seu caráter totalitário. A expansão do poder de controle em paralelo ao exercício do poder disciplinar não ampliou a liberdade do indivíduo preso. Contudo, pode-se afirmar que houve uma redução na incidência de mecanismos disciplinares, que se ocupavam de regrar cada movimento do preso, pois, como já dito, não importa o que ele faça desde que seja mantido neutralizado.

O poder disciplinar tem como função re-significar o indivíduo, conformá-lo a partir de outros padrões, controlar o sentido de sua a existência. Já o poder de controle visa tornar o individuo insignificante, com a existência reduzida, esquecida, descartável.

\subsection{Bom preso ou bom criminoso}

“...deve-se reconhecer que a prisão fechada implica em um sistema repressivo, totalitário, em que o preso deve obedecer cegamente, se quiser obter um certo grau de reconhecimento por parte da Administração....Ora, essa obediência cega é apenas aparente, ou seja, o preso aprende desde logo a mistificar, assumindo uma posição comparável a esquizofrenia: finge acatar, assimilar e respeitar tudo o que lhe foi permitido pela Administração. Na verdade porém vive outra vida, inteiramente diversa, acatando, assimilando, aprendendo $e$ 
respeitando realmente tudo aquilo que é passado pelos seus companheiros de prisão"

(Pimentel, 1983, p. 154)

Segundo Baratta (2002), a aculturação (assunção dos valores e da cultura prisional) engloba dois processos característicos: educação para ser um bom criminoso e educação para ser um bom preso. A necessidade de adaptar-se às normas passa a exigir do preso que ele interiorize modelos exteriores de comportamento necessários à preservação da vida institucional.

A educação para ser um bom preso aos olhos da Administração passa pela internalização das regras formais da instituição ${ }^{62}$. O preso deve demonstrar uma postura conformista no decorrer da execução de sua pena para provar ao sistema jurídico-penal (ao juiz, aos técnicos, ao diretor) que está "ressocializando", pronto para acatar os valores do sistema social (por exemplo, "vencer pelo trabalho e estudo") e obedecer às suas regras.

Nesse sentido, são atitudes esperadas do bom preso: estar estudando e/ou trabalhando, não cometer faltas graves, ter uma boa relação com a diretoria e a equipe técnica, e acima de tudo, demonstrar disciplina, mantendo a cabeça abaixada e a fala afinada com o discurso institucional.

O sucesso da aplicação dos mecanismos disciplinares (e da absorção pelo preso dos padrões de conduta esperados pela instituição) faz com que ele tenha uma avaliação positiva por parte dos técnicos e da Administração prisional, o que poderá influenciar positivamente na concessão de benefícios. Porém, tal postura, obediente e passiva, o desabilita para o convívio social:

"Na verdade não é muito difícil ser bom preso, para aquele que chega a dominar os nervos. O que é mais difícil é saber para que pode servir um bom preso, uma vez que sua pena tenha terminado"

\footnotetext{
${ }^{62}$ Como já visto no item 3.5. deste capítulo, o alto grau de conformismo do bom preso em relação às exigências institucionais o aproxima do modelo de ajuste primário da teoria de Goffman.
} 
(Simone Buffard apud Thompson, 2002, p.15)

Porém, além de cumprir com as expectativas da Administração, o encarcerado tem que seguir também o padrão imposto pelos outros presos. Ainda que as exigências de um e de outro sejam em sua maior parte conflitantes entre si $^{63}$.

O conflito entre ser bom preso ou bom criminoso pode ser expresso no dilema do "decentemalandro" construído por Violante (1982) em pesquisa sobre adolescentes da Febem- SP. A tensão entre ser decente e, portanto, acomodar-se "às suas condições marginais de sobrevivência", ou ser malandro, optando pela "insubmissão às suas condições anti-sociais de existência” caracterizará o modo de subjetivação do indivíduo marginalizado (Violante, 1982, p. 182).

A educação para ser bom criminoso está relacionada com os valores e hierarquia instituídos pelos próprios presos. Um grupo restrito de presos que serve de modelo para os demais, pois gozam de poder e prestígio na instituição, chegando a disputar com a Administração o "poder normativo de fato". Na realidade do atual sistema prisional brasileiro, esse grupo pode ser identificado como os líderes das facções criminosas: "ser do partido é uma espécie de credencial que atesta a qualidade do criminoso" (Amorim, 2006, p.34).

Apesar dos integrantes de tais grupos serem considerados de forte "tendência anti-social" e não ajustados às normas oficiais, são ao mesmo tempo os indivíduos menos vulneráveis, mais respeitados e de identidade mais desvinculada dos moldes da instituição, que de algum modo, forjam a identidade institucional em busca de outra forma de subjetivação.

Contudo, conforme será analisado no Capítulo 7 desta dissertação, a construção de uma identidade descolada dos moldes institucionais, mas submissa às exigências da organização informal, não trouxe mais liberdade, tampouco, autonomia ética para o indivíduo. Essa outra

\footnotetext{
${ }^{63}$ A relação entre “ordem “formal” e “informal” será aprofundada no próximo Capítulo.
} 
forma de subjetivação do preso, que resiste à institucionalização e é construída entre seus pares será denominada por Silva ${ }^{64}$ (1998) identidade delinqüente:

"A tese central deste trabalho é a de que o processo de socialização dos internos, a interação entre os grupos e os subgrupos e a utilização dos mecanismos de resistência são os fatores que mais decisivamente influenciaram para forjar a 'identidade institucional' que, com a evolução no ciclo da institucionalização, metamorfoseou-se em 'identidade delinqüente', posteriormente consolidada pela reincidência e pela multirreincidência.”

(Silva, 1998, p. 137)

\footnotetext{
${ }^{64}$ Para a realização dessa pesquisa, o autor usou a própria história de vida como metodologia de pesquisa, partindo da investigação de sua experiência de institucionalização para construir um saber desvinculado da interpretação oficial. O processo de apropriação e elaboração de sua própria história contribuiu para que Roberto da Silva resistisse e construísse uma identidade autônoma, diversa da institucional e da delinqüente.
} 


\section{Segunda Parte: AS LEIS DO CÁRCERE}

\section{CAPÍTULO 4}

\section{ARRANJO DO PODER NA PRISÃO}

\subsection{Esclarecimentos iniciais}

Para compreender de que modo o indivíduo se relaciona com as regras da prisão, essa segunda parte do trabalho tentará mapear algumas dessas regras, a partir da análise dos poderes exercidos no mundo prisional, explicitando de que forma elas se comunicam e quais as conseqüências do fortalecimento das facções criminosas dentro dos estabelecimentos prisionais no arranjo dessas ordens.

Partindo do pressuposto foucaultiano de que o poder não se possui, mas se exerce, torna-se uma tarefa difícil situar, dividir ou classificar ${ }^{65}$ as manifestações de poder. Contudo, nomear e agrupar esses exercícios, ainda que para fins analíticos, se mostrou necessário, mesmo com a certeza de que qualquer tentativa de classificação ${ }^{66}$ falha ao tentar captar um objeto tão difuso e dinâmico. Por isso não se pretende com esse capítulo apreender a totalidade dos poderes que se exercem na prisão, mas apenas traçar algumas perspectivas de análise, a partir de possíveis formas de sua manifestação.

\footnotetext{
${ }^{65}$ Até porque a categorização é uma estratégia do próprio poder-saber de constituição do objeto de estudo: limitálo, produzi-lo controlá-lo.

${ }^{66}$ Donald Clemmer (1958) foi o primeiro a desenvolver os conceitos de organização formal e informal. José Ricardo Ramalho (2002), em belíssima etnografia da Casa de Detenção de São Paulo realizada em meados dos anos setenta, classifica as "leis na prisão" a partir de dois códigos normativos: regras de funcionamento (ditadas pela direção do estabelecimento) e as leis da massa (conjunto de regras elaboradas e aplicadas pelos próprios presos). Rosa Maria Fisher (1989) em tese de livre-docência sobre organização penitenciária analisa o poder na prisão em dois níveis: o primeiro relacionado à estrutura formal, composto pelos espaços organizacionais e o segundo ligado ao poder informal, que permeia todas as relações no âmbito prisional. Myriam Mesquita Castro (1993) se refere a relações sociais mediadas por práticas institucionais e cotidianas. Roberto Borbato Júnior (2007) ao estudar e analisar os diversos modos de juridicidade na prisão e fora dela, atesta a existência de duas ordens jurídicas: estatal (fontes normativas legais) e não-estatal (normas informais).
} 
De início, seriam analisados somente dois códigos normativos enquanto regras que regem o mundo prisional: aquele produzido pelo Estado (ordem formal) e outro produzido pelos próprios presos (ordem informal). Porém, percebeu-se que a análise das esferas formal e informal não bastaria para abranger as "leis" ${ }^{67}$ do universo prisional. Além das leis estatais e das leis da massa, a disciplina atua no ambiente prisional enquanto tipo de poder normalizador, o qual, mais do que os códigos expressos, determina o dia-a-dia na prisão.

A dinâmica do poder na prisão não pode ser apreendida dentro de uma lógica binária, fechada e abstrata; por isso se mostrou indispensável incluir nesta análise as disciplinas, para entender como os códigos normativos formal e informal são aplicados na prática, e o que foge àquilo que está previsto neles. A disciplina age nos espaços que escapam às leis, mas nem por isso compete com elas. Ao contrário, são os mecanismos disciplinares que garantem a eficácia e a manutenção dessas ordens.

Uma abordagem meramente jurídica ${ }^{68}$ não daria conta das relações prisionais, já que a prisão é uma instituição disciplinar por excelência. A disciplina escapa ao direito, assim como a detenção escapa à pena. Para entender a lógica prisional, é necessário observar as assimetrias, as relações de poder, mais do que a lógica formal centrada nas mãos do Estado. Mesmo a aplicação das regras instituídas pelos próprios presos, ainda que estas estejam cada vez mais difundidas e institucionalizadas, tem nuances que não podem ser captadas a partir somente da análise desse código normativo informal.

Portanto, considerando o poder não como um atributo de instituições e pessoas, mas a partir de seu aspecto dinâmico, trabalhar-se-á com três tipos de registros de poder nas prisões: jurídico, disciplinar e aquele exercido pelos próprios presos. Nessa análise, evitar-se-á a idéia

\footnotetext{
${ }^{67}$ Conforme já esclarecido anteriormente, a palavra lei é utilizada neste trabalho em sentido amplo, não identificada, necessariamente, à função legislativa do Estado, mas enquanto regra que determina o comportamento na prisão.

${ }^{68}$ Para Clemmer (1958) o alcance da organização formal da comunidade prisional vai além da regulamentação jurídica. A organização formal abrangeria a estrutura física e de pessoal, ritual de entrada, classificação dos apenados, sistema de punição e recompensa , sistema de alojamento e alimentação, as indústrias e as demais possibilidades de trabalho no cárcere, e educação, religião e recreação.
} 
de que o poder pertence ao estabelecimento prisional, à direção ou aos funcionários, ou aos presos e às facções criminosas, para situá-lo justamente na relação entre esses atores.

No texto Soberania e disciplina, Foucault (2004, p. 182-184) atenta para quatro preocupações metodológicas necessárias ao desenvolvimento de uma análise do poder para além das relações de soberania (campo da lei), de forma a captar seu exercício também nas relações de dominação e sujeição (campo da norma); são elas:

a) estudar o poder nas “suas formas e suas instituições mais regionais e locais”, a partir de suas ramificações e extremidades; justamente onde ele ultrapassa o alcance das regras jurídicas;

b) analisar o poder na sua manifestação, nas suas práticas reais, não sob um plano abstrato;

c) não dividir os indivíduos entre os que sujeitam e os que são sujeitados. O poder circula, não

é propriedade de determinados indivíduos, todos de alguma forma o exercem e sofrem a sua ação;

d) realizar uma análise ascendente do poder, a partir de sua atuação nos níveis mais baixos para então chegar a mecanismos mais gerais.

Tais alertas serviram de guia para uma possível reconstrução, no âmbito desta pesquisa, do campo de poder prisional, principalmente no que tange à formulação da ordem disciplinar e na análise crítica das demais ordens.

\subsection{Constituição da dinâmica no cárcere: simbiose entre ordem legal, disciplina e leis da massa}

“O predomínio desta estrutura formal, expressa nos regulamentos é, no entanto, constantemente contestada pelo estudo e pela prática das prisões. Por eles se verifica que a vida em um estabelecimento prisional depende do 
consentimento dos internos e, muito mais do que se esperaria, pelo simples conhecimento da estrutura formal. Por mais severo que seja o regime, há sempre um sistema de barganha, de troca de concessões entre presos e funcionários. Às vezes, essa relação confunde-se com a própria corrupção do sistema, mas tudo indica que o funcionamento sem percalços dessa rede informal de informações é que evita distúrbios.”

(Rios, 1998, p. 10)

Os mecanismos de poder que atuam na prisão podem ser associados aos diferentes saberes que a conformam. E sua atuação só é possível graças a um arranjo harmônico entre o saber legal-institucional e daquele produzido pelos próprios presos. Quem está na posição de poder (a qual não é fixa e sim relacional), define as normas e os padrões de normalidade.

Na presente pesquisa, optou-se por nomear ordem formal o conjunto de instrumentos normativos emanados pelo Estado, e informal o conjunto de regras produzidas pela massa carcerária. Mas tal classificação merece ser problematizada, uma vez que a atribuição de formalidade é sempre referencial, e depende da perspectiva de onde se olha. A ordem instituída pelas facções na prisão pode ser revestida de tanta formalidade quanto a ordem estatal, uma vez que muitas de suas leis são escritas e suas ações ritualizadas ("batizado”, julgamentos, hinos etc.).

Apesar da premissa de que os códigos normativos na prisão são formulados pelo Estado e pelos próprios internos, o poder que rege a dinâmica prisional pode ser melhor apreendido na observação dos mecanismos disciplinares, que não estão situados nem nas estruturas estatais nem nas mãos de quem quer que seja, pois não pode ser possuído, mas só exercido.

O poder disciplinar não está situado em uma instituição nem pertence a uma pessoa, tampouco é imposto por um indivíduo sobre outro, em um fluxo único. Ele transpassa as relações sociais, tomando formas diversas e formando uma rede de mecanismos disciplinares, da qual ninguém escapa e à qual todos, de alguma forma, sujeitam-se e são sujeitados. 
Logo, os mecanismos disciplinares não podem ser classificados enquanto pertencentes à ordem estatal ou não-estatal, pois são eles mesmos o ponto de encontro dessas duas esferas. Para criar as diferenças e assimetrias entre os presos, a disciplina apóia-se tanto na legitimidade do sistema legal, pretensamente justo e igualitário, quanto na força da organização e hierarquia dos próprios presos, uma vez que são eles os responsáveis por "segurarem a casa”, como será visto a seguir.

A disciplina constitui uma tecnologia positiva de exercício do poder, um mecanismo estratégico, organizado em torno de um conjunto de táticas e técnicas de controle que se ocupam de cada detalhe da vida do indivíduo, fixando-o em um espaço, controlando seu tempo e vigiando, registrando e examinando sua conduta. É, por isso mesmo denominada por Foucault (2002, p.120) anatomia política do detalhe, não com o objetivo de apreender o sentido do detalhe, mas por ser pelo detalhe que ela exerce seu poder. A partir de processos sutis, ela se insere, capilarmente, nos detalhes da vida, determinando a forma de ser dos indivíduos.

"Esses métodos que permitem o controle minucioso das operações do corpo, que realizam a sujeição constante de suas forças e lhe impõem uma relação de docilidade-utilidade, são o que podemos chamar as 'disciplinas'”,

(Foucault, 2002, p.118)

A docilidade pode ser entendida aqui no sentido de submissão, de produção de uma individualidade obediente, que seja útil ao funcionamento do sistema social. A disciplina é um poder produtivo, que faz do corpo uma aptidão. Enquanto aumenta as forças do corpo em temos econômicos, sujeita aos seus domínios a potência decorrente dessa força, diminuindo-a em termos políticos (Foucault, 2002, p.118). 
"Foucault chama-as ainda instituições de seqüestro, em razão que a reclusão que elas operam não pretende propriamente 'excluir' o individuo recluso, mas antes 'incluí-lo' num sistema normalizador”

(Muchail, 1985, p.200)

Esse poder que inclui perversamente não é um ente abstrato, identificado somente com os preceitos legais repressivos; ele tem, antes de tudo, uma atuação concreta, atuando e se constituindo nas relações sociais, nas práticas discursivas e nos mecanismos de controle. Mais do que as leis, são as práticas e saberes da Administração prisional e da massa carcerária que legitimam as relações instituídas no âmbito prisional.

O poder disciplinar incide sobre o preso classificando-o, separando, examinando e produzindo um saber sobre o delinqüente; e garantindo, no âmbito prisional, uma ampla discricionariedade na tomada das decisões, a permanência da lógica de castigos e recompensas e a manutenção de privilégios e acertos.

Enquanto o campo da lei, que abrange a ordem legal (e mesmo as leis da massa carcerária) estaria mais ligado ao exercício do poder soberano, caracterizado por certa previsibilidade e rigidez. Já o campo da norma é fluído, inapreensível e mutável, e corresponderia à zona cinzenta da prisão, situada entre o legal e o ilegal (Castro, 1993), lugar onde estão assentadas as assimetrias, os acertos, as irregularidades.

O exercício do poder por parte de um ator social não exclui que outro ator também o faça. Apesar de a Administração Penitenciária e a massa carcerária representarem interesses diametralmente opostos, o exercício do poder por parte de um não se contrapõe necessariamente ao outro.

As ordens, formal e informal, não disputam necessariamente a hegemonia do poder prisional. O enfrentamento dessas duas esferas só ocorre quando há um desequilíbrio de arranjo de poder, o qual resultará em rebeliões, fugas, motins (Salla, 2006). A regra é que elas exercitem o poder de forma complementar, já que, mesmo que por diferentes meios, ambas têm alguns objetivos 
parecidos: manter sua posição na organização prisional; extrair utilidade e garantir a obediência do preso; e assegurar que a prisão esteja "sob controle”.

A Direção da prisão tem interesse na obediência do preso, assim como aqueles que exercem o poder informal, pois quanto mais obediente o indivíduo, mais útil será, e vice-versa. A partir da disciplina, tanto a instância formal como a informal subjugam o indivíduo às suas forças e “transformam multidões confusas, inúteis ou perigosas em multiplicidades organizadas”

(Foucault, 2002, p.127), ainda que para extrair delas utilidades diversas.

Levando-se em conta o número de agentes de segurança em comparação ao número de presos, somado ao fato de que os agentes estão desprovidos de armas de fogo, conclui-se pela total impossibilidade de que a ordem seja mantida exclusivamente pelo exercício da coação física do Estado.

E como a ordem formal não consegue dar conta de manter essa dominação sozinha, ela se apóia nas lideranças dos presídios para a tarefa de garantir o controle dos internos (Salla, 2006, p.278). Em troca, essas lideranças têm seu poder reconhecido pela Administração Prisional e perante a massa carcerária, a partir do que podem extrair inúmeras vantagens.

Ao descrever a importância da ação das lideranças na manutenção da ordem prisional, Sykes vincula a habilidade desses presos em exercer o controle sob a massa carcerária às recompensas materiais oferecidas pela Administração Prisional:

"(...) O preso orientado pela idéia de coesão entre os internos, tem mais chance de ser favorecido nos padrões de corrupção estabelecidos entre guardas e reclusos"

(Sykes, 2007, p. 125, tradução da autora ${ }^{69}$ )

\footnotetext{
${ }^{69}$ No original em inglês:“(...) the prisoner oriented to the theme of inmate cohesion who is most likely to be favored in the patterns of corruption which grow up between guards and inmates "
} 
Apesar de o Estado já dividir parte do exercício de controle da prisão com as lideranças da massa carcerária antes da presença das facções ${ }^{70}$ no cotidiano prisional, tal prática foi ampliada com o fortalecimento dessas organizações (visto que o poder dos presos aumentou) e o controle sobre os presos se tornou mais eficaz, realizado de forma mais central e permanente.

O controle formal faz vista grossa quanto ao que ocorre na prisão, seja por não conseguir sobrepor-se a essa realidade, seja pelas vantagens diretas e indiretas daí obtidas. Os agentes estatais obtêm, ao permitir e participar das irregularidades e ilegalidades no meio prisional, vantagens diretas advindas da própria corrupção. E, indiretamente, a vantagem está no fato da multidão confusa continuar sob controle, ainda que esse controle advenha do poder das facções - o que pode significar um grande risco ao Estado quando há um desequilíbrio desse arranjo de poder (Estado - facções).

O aperfeiçoamento dos mecanismos disciplinares no campo prisional ocorreu em função da ação dos detentos sobre eles mesmos. Os papéis de controlado e de controlador, que no caso do controle formal seguem um modelo rígido e é exercido por sujeitos em condição opostas (preso $\mathrm{x}$ agente estatal ${ }^{71}$ ), passam a ser exercidos pelo mesmo grupo de indivíduos: os próprios presos.

Com essa mudança, o poder passa a ser efetivamente capilar e onipresente, uma vez que o olhar se estende a todos os ambientes da vida prisional (cela, pátio, igreja, visita). Como a regra $^{72}$ da prisão é a vida em massa, um preso está sempre na companhia de outro, com pouquíssimos momentos de privacidade.

\footnotetext{
${ }^{70}$ Apesar de muitas vezes as facções criminosas serem vistas como ameaça ao Estado de Direito, simbolizando o outro, inimigo da sociedade, a atitude desses grupos enquanto resistência ao poder exercido pelo Estado não está alheia a ele, e por isso mesmo, os atos de resistência desses grupos podem ajudar a uma melhor compreensão da ação do poder. (Foucault, 2005, p.135). Esse debate será retomado adiante, no Capítulo 6.

${ }^{71}$ Na classificação de Goffman (1974): internos e equipe dirigente.

${ }^{72}$ As exceções estão justamente nos estabelecimentos prisionais de disciplina rígida nos quais se exerce uma vigilância onipresente do preso (inclusive com monitoramento por câmeras) e têm como base seu isolamento total; tais estabelecimentos estariam inseridos na nova economia da punitividade que abandona de uma vez a falácia "ressocializadora" para se legitimar pelo controle puro, cujo objetivo final é excluir o outro e não mais adestrar seu comportamento. Tais como o Regime Disciplinar Diferenciado, criado, entre outras coisas, para controlar alguns presos supostamente envolvidos com as facções criminosas, limitando seu contato com outros presos e com o exterior.
} 
As facções, ao realizar um controle ininterrupto que desce às menores esferas da vida prisional, exercitam um poder com características notadamente disciplinares. Porém, o rigor de suas leis, somado às punições exemplares - punições públicas que marcam os corpos e os expõem, semelhantes aos suplícios relatados por Foucault (2002) - o aproximaria do poder soberano.

\subsection{Gerenciamento da dinâmica prisional: a legitimação das práticas}

Ao longo do século $\mathrm{XX}^{73}$, foi exigido do sistema penitenciário que cumprisse fins contraditórios: punir o infrator, retribuindo o "mal praticado” por ele com a pena de prisão; e ao mesmo tempo “ressocializá-lo”, prepará-lo para o retorno ao convívio social ${ }^{74}$. Nesse sentido, a disciplina seria um meio para se exercer o que Thompson (2002) denominou como função punitiva e função terapêutica do cárcere.

Se, na teoria, já se vislumbram limitações para que esses dois objetivos sejam alcançados concomitantemente, na prática do sistema prisional eles se tornam praticamente irreconciliáveis.

A análise da condição de agente penitenciário proposta por Moraes (2005) é uma ótica privilegiada para se vislumbrar as contradições inerentes ao sistema prisional. Os agentes penitenciários, dentre os funcionários do sistema prisional, são aqueles que estão em contato mais próximo e direto com os presos, que ocupam a "linha de frente" do embate entre dirigentes e dirigidos. São os principais responsáveis por manter a ordem no cárcere, e aqueles que estão mais expostos aos riscos dessa atividade.

\footnotetext{
${ }^{73}$ No final dos anos 70 a idéia de ressocialização enquanto função principal da pena de prisão, já estava em decorrada na Europa Ocidental quando ganhou força no Brasil, com reflexos nos discursos jurídicos e criminológicos, no saber das instituições prisionais e no ordenamento legal (principalmente na formulação da Lei de Execução Penal de 1984).

${ }^{74}$ Nesse sentido a metáfora difundida por Zaffaroni de que: almejar reinserir o preso na sociedade a partir de seu confinamento seria como querer ensinar alguém a jogar futebol dentro de um elevador.
} 
De modo a sustentar o discurso dos direitos humanos e da dignidade no tratamento dos presos, requer-se desses funcionários que "segurem a casa", sem que para isso façam uso de violência. Porém, essa se torna uma tarefa praticamente inatingível em um ambiente onde a violência permeia todas as relações sociais, e em que, muitas vezes, seu uso ainda que moderado seja necessário para conquistar o respeito dos presos ${ }^{75}$.

Segundo Fisher (1989), o vácuo criado por essa ambigüidade dos fins da pena, somado à falta de diretriz política e organizacional, fez com que os estabelecimentos penitenciários formulassem seus próprios objetivos e padrões de procedimento, levando ao que ela denominou gerenciamento do cotidiano prisional.

O gerenciamento, segundo a autora, consiste em um conjunto de práticas formais e informais, capazes de garantir o bom funcionamento da casa dentro de um sistema em que a autonomia do estabelecimento prisional é reforçada pela falta de transparência dessas gestões perante os demais órgãos estatais e a sociedade civil (Fisher, 1989, p. 80).

No entender de Góes (2004, p.222) o gerenciamento consiste justamente na administração autônoma e pouco transparente das prisões, a partir de práticas e procedimentos formais e informais.

O gerenciamento corresponderia, então, à forma de administração descentralizada do cotidiano prisional, a partir de práticas instituídas em cada unidade prisional. Longe de ser uniforme e previsível, o modo como cada unidade será gerenciada dependerá da conjuntura particular de cada uma delas, formada por seus aspectos culturais (tais como o histórico do estabelecimento, o perfil do Diretor, o grau de influência dos presos) e pelas relações de poder que estão ali estabelecidas.

\footnotetext{
${ }^{75}$ Segundo Moraes (2005, p. 262) os agentes penitenciários podem ser classificados em 3 grupos a partir do uso que fazem da violência: o bundão que não enfrenta o preso; o sangue ou caceteiro que enfrenta os presos, mas pode ocorrer em excessos; e o esquilibrado "que dá pau quando tem razão, quando tem motivo", ou seja, faz uso da violência d uma forma justa no entender dos presos.
} 
O regramento do dia-a-dia prisional é caracterizado por pequenos ajustes, a partir dos quais são obtidos tolerâncias e privilégios. As práticas do cotidiano prisional, os arranjos, os acertos, as pequenas ilegalidades, são acordados tanto entre a massa carcerária quanto entre os funcionários e a direção do sistema.

É essa conclusão da Comissão Parlamentar de Inquérito do Sistema Prisional de 1996 relatada pelo então deputado Wagner Lino (1996):

"o sistema punitivo e repressivo expressa uma situação de descontrole por parte das autoridades responsáveis, seja a nível das (sic) Secretarias de Governo, seja a nível do Sistema Judiciário propiciando a perpetuação de uma lógica interna nos estabelecimentos, que penaliza tanto funcionários como presos, ainda que estes participem e reproduzam esta lógica desumana e violenta"

O poder do diretor, assim como sua capacidade de interferir nos padrões constituintes da dinâmica prisional, fica limitado pela tendência à perpetuação das práticas consolidadas no estabelecimento que dirige. Os funcionários resistem tanto a se submeter à autoridade de alguém novo (que "não conhece nada da Casa”) quanto a mudar a forma até então adotada para gerir a prisão.

Isso ocorre devido à grande alternância daqueles que ocupam o cargo de direção, em contraposição a permanência dos demais funcionários, os quais lutarão pela perpetuação dos comportamentos adotados na "sua instituição" (Thompson, 2002). Como o saber não está desvinculado do exercício do poder, à medida que sustenta e é sustentado por ele, é compreensível que aqueles que detêm a hegemonia do conhecimento não queiram compartilhá-la.

A participação dos funcionários será imprescindível para o funcionamento do chamado sistema de privilégios, o qual, de acordo com Goffman (1974), conformará o modo de organização das instituições totais. Esse sistema se caracteriza pelo uso do castigo dentro de modelos de condicionamento aplicados a animais e crianças; pela possibilidade de influir na 
perspectiva de liberdade do preso; e pelos locais de privilégio estar geralmente relacionados ao local de trabalho e de dormir.

Esse sistema, essencial à organização do mundo prisional, é composto ainda por três elementos: pelas regras da casa (conjunto relativamente explícito de regras e proibições que expõe as principais exigências quanto à conduta do internado); pelo sistema de prêmios e privilégios claramente definidos, obtidos em troca de obediência, em ação e espírito, à equipe dirigente; e, ainda, pelos castigos enquanto conseqüência de desobediência às regras que traz como conseqüência a recusa temporária ou permanente de privilégios (Goffman, 1974, p. 50).

A Administração, ao legitimar o tratamento diferenciado entre os presos e o domínio de uns sobre os outros, rompe com a pretensa igualdade dos presos, instituindo assimetrias construção típica do poder disciplinar.

As práticas do cotidiano prisional, além de garantir a estabilidade das relações infrainstitucionais, estabelecem, nas palavras de Castro, o controle subterrâneo do sistema:

"É o segredo dessa ordem que funciona pelo avesso, dessa ordem que funciona na desordem, na qual as normas são vigidas e quem deve paga com a vida"

(Castro, 1991, p.59)

O poder se imprime na dinâmica prisional de forma capilar: discreta e utilitariamente, percorrendo todas as questões decisivas da vida do preso. Serão as práticas que irão determinar, por exemplo, a ocupação do espaço prisional (na distribuição dos presos nas celas e raios), assim como a escolha de quais presos ocuparão as vagas de trabalho (apesar da LEP prever que os trabalhadores serão escolhidos conforme "aptidão, disciplina e responsabilidade para exercerem as funções”). 


\subsection{Negociação do poder prisional}

A gestão do cotidiano prisional é um jogo de concessões entre dirigentes e presos (Salla, 2006). Para Fisher (1979), o poder da organização prisional está diretamente relacionado com a forma com que as posições hierárquicas estão distribuídas na instituição, assim como com a capacidade de controle das informações e dos bens valorizados por determinada cultura. Sob essa perspectiva, a direção dos presídios paulistas, na atualidade, teria pouco domínio do poder organizacional da instituição que administra.

A negociação do poder prisional ocorre em todos os níveis, envolvendo inclusive os atores que ocupam uma posição inferior na hierarquia da massa carcerária e na Administração prisional. Entretanto, a posição privilegiada ocupada por alguns presos dentro da hierarquia da facção, indivíduos cuja autoridade é reconhecida tanto pelos demais presos quanto pela própria Direção do estabelecimento prisional, faz com que os que ocupantes dos graus mais altos da hierarquia estatal negociem o cotidiano prisional com aqueles que ocupam a mesma posição perante a massa carcerária.

Uma hipótese recorrente em diversos trabalhos (Sykes, 2007; Salla, 2006; Fisher, 1989; Thompson, 2002) é a de que, por não dispor de força para manter a massa subjugada, o Diretor do presídio entrega parte da administração da dinâmica prisional aos próprios detentos (no caso da atual realidade paulista, esse poder seria entregue aos líderes das facções criminosas):

“ocorreu uma privatização do controle interno das unidades prisionais pela cooptação das lideranças criminosas pelos gestores num pacto de manutenção de ordem mínima. É a gestão partilhada (...). É a fase em que as autoridades abdicaram de comandar a disciplina interna e ampliaram a comunicação dos presos com o ambiente externo"

(Caldeira, 2005, p. 31)

A disseminação de tal prática talvez não deva ser vista como uma simples “falha” na administração dessas instituições, mas como constitutiva delas. A pretensão de que a 
instituição de custódia mantenha o poder completo e total sobre os presos é uma ilusão que não encontra sustentação na realidade prisional.

Para Sykes (2007, p.129), é impossível que a burocracia estatal mantenha o poder total e completo sobre o estabelecimento. O fato da sociedade não tolerar a idéia da influência dos próprios presos na configuração do sistema prisional, a partir do exercício do controle informal, gera instabilidade nos sistemas prisionais, à medida que a vontade da população e o discurso repressivo não conseguem transpor a complexa realidade.

Essa negociação se dá tanto em nível micro, no interior de cada estabelecimento, quanto em nível macro, nas instâncias de decisões estaduais. A suspeita ${ }^{76}$ de que o governo do Estado de São Paulo teria negociado o fim dos ataques que pararam a cidade de São Paulo, em 2006, com o suposto líder do PCC, Marcos Camacho (Marcola), é significativa nesse sentido. Apesar da denúncia da imprensa, perante as afirmações de Marcola em depoimento na CPI do Tráfico de Armas ${ }^{77}$, o governo estadual continuou negando veementemente qualquer tipo de negociação. Ao ser questionado sobre o assunto, o então governador Claúdio Lembo afirmou enfaticamente: "Não admito essa hipótese, é deselegante comigo, desrespeitoso. Negocio com trabalhador, pessoas honradas, não com bandido".

O governador produz um discurso ambíguo ao negar a hipótese de negociação, e ao mesmo tempo, admitir que tenha sido feito “contato" com Marcola por meio de uma advogada, um representante do Governo e um coronel da Polícia Militar. O governador chega a afirmar: "Mas estou convicto mesmo que, se cederam os celulares, naquele momento era positivo, não seria negociação, mas apenas a preservação da vida, de todos nós e da sociedade paulista, é tudo aceitável”. O Governador ainda “completou informando que a prioridade era manter a ordem pública e a disciplina social”. ${ }^{78}$

\footnotetext{
76،“Guerra urbana/Trégua: Cúpula do PCC ordena fim dos ataques” .http://www1.folha.uol.com.br/fsp/cotidian/ff1605200602.htm, acesso 09/10/ 2007

${ }_{77}$ Disponível no endereço http://www1.folha.uol.com.br/folha/cotidiano/20060708-marcos camacho.pdf , acesso 13/11/2007.

78 "Lembo admitiu que houve um diálogo entre um coronel da Polícia Militar, Aílton Brandão, um representante do governo e a advogada Iracema Vasciavelo, no presídio. "O contato eu nunca neguei", comentou ele. "Mas que tipo de negociação é essa, em que ele (Marcola) está preso em RDD?", questionou ele. "Somos firmes na
} 
Se o objetivo principal do governo era manter a disciplina social e salvar vidas, para dessa forma retomar aparentemente o controle da cidade e acalmar a população, o “contato” seria um custo a ser pago. O fato das autoridades terem se dirigido até a Penitenciária para conversar com um preso simboliza o reconhecimento por parte das instâncias públicas da influência da facção sobre a ordem prisional (e até social), e da incapacidade do Estado de contornar a crise “sozinho”.

Independente do conteúdo do que foi acordado naquele dia, o encontro (ou "contato” como o governador preferiu denominar) daqueles personagens, representando vários poderes, é, do ponto de vista simbólico, uma representação do arranjo de poder no âmbito da Administração Penitenciária e Segurança Pública.

De acordo com Marcola, reuniram-se com ele no Presídio de Presidente Bernardes, onde ele se encontra cumprindo pena em Regime Disciplinar Diferenciado: uma advogada, um Coronel, um delegado (enviado pela cúpula da Secretaria de Segurança Pública) e o corregedor dos presídios (representando a Secretaria de Administração Penitenciária). Como ele relata no trecho do depoimento de Marcola ao presidente da CPI, Deputado Paulo Pimenta:

“Deputado - Sobre a questão do... do domingo aqui, podia nos contar mais ou menos? O que aconteceu? Estava na sua cela, aí mandaram te chamar...

Marcola - Isso.

Deputado -... Que queriam falar contigo...

Marcola - Queriam... Não sabia nem quem era.

(...)

Deputado - estava só tu primeiro

Marcola - Só eu...

Deputado - Com eles, com esse pessoal?

preservação da ordem e da disciplina social", disse Lembo, acrescentando que não negocia com criminosos” "Lembo volta a negar acordo com o PCC para fim de ataques":

http://www.estadao.com.br/arquivo/cidades/2006/not20060609p27995.htm, acesso 10/10/ 2007. 
Marcola - Com esse pessoal.

Deputado: - ...Bom, aí chegou aqui, estava a Iracema, que tu nunca tinha visto, correto, o Coronel daqui da região...

Marcola - É.

Deputado - Um...

Marcola - Um, um delegado.

Deputado - Um delegado e um da Secretaria...

Marcola - O delegado veio falando que era mandado do Secretário de Segurança.

Deputado - Secretário Saulo.

Marcola - Pela cúpula da Secretaria da Segurança

Deputado - E o Corregedor dos Presídios.

Marcola - E esse Corregedor, da Secretaria Administrativa dos Presídios.

Deputado - Certo. Aí vieram falar contigo: 'Olha viemos aqui falar contigo por causa da rebelião'

Marcola - Mas não falavam nada com, assim... Eu estranhei muito. Falei: o que vocês querem? Que eu ligue, que eu... O que vocês querem? Eles também não sabiam muito o que me dizer... Deputado - E a Iracema, como é que apareceu na história?

Marcola - Ela falou: 'Não, a gente quer que você pegue o telefone e diz pra alguém ali que você está bem de saúde, que ta tudo bem’.

Ainda em fevereiro de 2001, ao responder a suposta exigência feita pelo PCC de transferência de um preso do presídio de segurança máxima anexo à casa de custodia de Taubaté (conhecido entre os presos como Piranhão), o então Secretário de Segurança Pública do Estado, Marco Vinicio Petrelluzzi, afirmou: "Com quadrilha de bandido não tem conversa. O governo está enfrentando esses marginais com a dureza que a lei permite" 79 .

Devido ao aumento de fugas e rebeliões no sistema prisional paulista, a Secretaria de Administração Penitenciária (SAP) instituiu, a partir da Resolução 42 de 1996, o chamado “Grupo de Negociadores”, que tem como objetivo intervir na ocorrência de motins e rebeliões

79 "Petrelluzzi: não negocio com bandidos" http://www.estadao.com.br/arquivo/cidades/2001/not20010228p17448.htm, acesso 5/12/07. 
nas unidades prisionais do Estado, avaliando a situação, ouvindo as reivindicações, negociando “o que for possível” e propondo algumas soluções (Marques, 1997, p.11).

No sentido de disseminar esse saber construído para conhecer e controlar as manifestações de resistência do preso, o Ilanud (Instituto Latino Americano das Nações Unidas para Prevenção do Delito e Tratamento do Delinqüente) editou o manual Gerenciamento de Crises no Sistema Prisional, com diretrizes para atuação nos chamados incidentes prisionais (fugas, rebeliões, movimentos reivindicatórios) "numa tentativa de sintetizar alguns princípios e métodos de ação que a Secretaria de Administração Penitenciária vem desenvolvendo nessa gestão" (Marques, 1997, p. 7).

O fato de a prisão ser um lugar onde o código normativo de comportamento é constituído pela violência (Adorno, 1993), somado à falta de controle sobre a massa carcerária ao longo dos anos, contribuiu para que as facções assumissem a administração da violência e, conseqüentemente, do código normativo das prisões. O suposto monopólio estatal da violência e mesmo o conceito da prisão enquanto instituição total merecem ser revistos a partir do fortalecimento do poder das facções sobre a massa carcerária.

As facções se aperfeiçoaram em termos organizacionais, principalmente com o desenvolvimento de estratégias internas e externas de comunicação e controle. Ao mesmo tempo em que se enraizaram dentro dos presídios, estas organizações expandiram-se pra fora, com tentáculos nas comunidades ${ }^{80}$, no mercado ilegal e nas instituições estatais.

\footnotetext{
${ }^{80}$ Inclusive alcançando popularidade com a promoção de festas, como a ocorrida na favela Morro do Samba em Diadema/SP, no final de 2006, cujas imagens foram veiculadas pela TV Bandeirantes, e se encontram disponíveis na internet: $h$ ttp://www.youtube.com/watch?v=a18Y3JA-q_4 acesso 10/12/07. Para uma abordagem mais aprofundada da influência do tráfico de drogas nas tramas urbanas e redes sociais, consultar as recentes pesquisas de Vera da Silva Telles (Telles e Hirata, 2007).
} 
Internamente, as facções criminosas controlam os recursos ilegais que circulam na prisão, tais como armas e drogas, e exercem grande influência na distribuição dos legais, como, por exemplo, as vagas para trabalhar junto à administração ${ }^{81}$ ou nas oficinas.

Os movimentos de insurgência dos presos podem ser tidos como resposta ao gerenciamento repressivo da prisão. Uma afronta para que os presos recuperem os benefícios perdidos e restabeleçam alguns favorecimentos, posições privilegiadas de poder (Sykes, 2007, p.126). Os conflitos são coibidos não pela repressão oficial, mas pela ação de alguns presos no sentido de restabelecer a coesão social entre os internos.

Para Sykes (2007), a rebelião não é um fato isolado e explosivo que atravessa surpreendentemente a dinâmica prisional. A rebelião emerge a partir de uma série de outras crises menores, de um "processo longo e profundo de desequilíbrio de poder" (Salla, 2006).

A prisão, diferentemente do que se afirma, não é um barril de pólvora prestes a explodir, mas caminha em um ciclo rítmico que vai da ordem à desordem (Sykes, 2007, p. 110).

Periodicamente, a organização prisional é afetada por crises. Isso acontece, quando os atores prisionais passam a desafiar aquele equilíbrio até então estabelecido, para chegar a um novo arranjo de poder. Esse arranjo durará até que novas crises o atinjam e haja uma reconfiguração das relações de poder, dando, assim, continuidade ao ciclo.

Ainda para Sykes, o poder prisional é negociado a todo tempo entre presos e Administração. Quando a Administração percebe que os presos estão exercendo muito poder, toma uma série de medidas para recuperá-lo, como o endurecimento do regime prisional e o fim dos privilégios e regalias. Tais medidas elevam o grau de tensão das relações estabelecidas no presídio, e marcam o início da efervescência da massa carcerária na tentativa de reaver o poder. São essas pequenas crises que, somadas, poderão resultar em uma rebelião:

\footnotetext{
${ }^{81}$ Além das vantagens normalmente decorrentes do trabalho na prisão, trabalhar nas funções burocráticas permite ao preso maior liberdade de circulação, e permanência por mais tempo fora do "raio". O que, ao final, representaria um grau menor de "prisionização"
} 
“os presos ressentem-se de qualquer mudança que se introduza no sistema sem sua autorização. Quando isso ocorre, geram-se resistências. Essas crises aparecem com mais freqüência nos períodos de mudança na organização dos presídios”

(Rios, 1998, p. 10)

\subsection{Política penitenciária e as facções criminosas}

“Por que hoje está o crime organizado? O sistema oprimiu muito o sentenciado, teve que dar na imprensa para ver o que o sistema fazia. Hoje está civilizado. Mas o sistema quer cada vez mais que se transforme em um monstro, quer aniquilar o projeto de vida". ${ }^{82}$

O surgimento das facções criminosas no sistema prisional paulista (e o fortalecimento delas em território fluminense) a partir dos anos 90 pode ser explicado a partir de duas chaves teóricas diferentes ${ }^{83}$. Uma delas o atribui à política leniente dos Governos estaduais nos anos 80. A outra identifica justamente o endurecimento da política criminal nos anos 90, somado à violência do sistema prisional, como principais causas da organização dos presos em torno das facções ${ }^{84}$.

Após quase duas décadas sob o regime militar, os anos 80 ficaram conhecidos como o período de redemocratização do país. André Franco Montoro, que governou São Paulo de

\footnotetext{
${ }^{82}$ Fala de um preso em um dos encontros do Grupo de Diálogo Universidade - Cárcere - Comunidade (GDUCC). Um dos objetivos dos encontros ocorridos no decorrer de 2007 era propor aos participantes a discussão acerca de seu "projeto de vida".

${ }^{83}$ Agradeço especialmente ao sociólogo Fernando Salla pela observação feita no exame de qualificação acerca dessas duas possíveis leituras. Da mesma forma, as rebeliões nas prisões podem ser compreendidas a partir de uma ótica mais conservadora enquanto conseqüência do afrouxamento do controle, ou enquanto movimentos dos presos de insurgência contra as violências do sistema (Salla, 2006, p.276).

${ }^{84}$ Cabe mencionar a dissertação de Alessandra Teixeira (2006) enquanto referência para a análise dos caminhos da política penitenciária brasileira na contemporaneidade e seus reflexos no sistema prisional brasileiro, especificamente no paulista.
} 
1983 a $1987^{85}$, nomeou o advogado e consagrado defensor dos direitos humanos José Carlos Dias como Secretário da Justiça. Nos seus três anos de gestão da Secretaria da Justiça (19831987), sua atuação foi no sentido de melhorar as condições dos presídios, assegurar os direitos básicos dos sentenciados e criar mecanismos para que eles pudessem exercer efetivamente o papel de sujeitos de sua Execução. As medidas implementadas pelo então Secretário compuseram a então chamada política de humanização dos presídios.

Além de lutar pela efetivação de garantias individuais, tais como assistência jurídica, ampliação de vagas no sistema e visita íntima nos presídios masculinos, Dias foi o responsável pela criação das Comissões de Solidariedade. As Comissões eram formadas por presos eleitos por voto direto e secreto de seus pares, o que, na visão de Teixeira (2006, p. 79-80), representou uma experiência única de participação política dos presos.

\section{O Relatório de visita da Comissão Teotônio Vilela à Penitenciária do Estado (CTV, 1984)} retrata quatro objetivos principais das Comissões de Solidariedade: exigir o cumprimento de normas e regulamentos, de forma a evitar a aplicação de penas suplementares à privação de liberdade (tais como castigos, chantagem, sevícias sexuais); agilizar e moralizar o serviço de prontuário, de forma a liberar os presos que já tenham cumprido sua pena, e para que não seja usado como meio de chantagem ou punição por parte dos agentes administrativos; erradicar a corrupção, pondo fim na negociação informal de direitos, serviços e mercadorias (banho de sol, colchão, cela, sabonete) assim como a violência que atinge os presos (tortura, intimidação) e seus familiares (revista vexatória, aliciamento sexual); e ainda, pacificar e conscientizar os demais presos.

Contudo, a atribuição de importância que as Comissões de Solidariedade tiveram enquanto uma conquista política dos presos deve ser feita com cuidado. Primeiro porque a criação das

\footnotetext{
${ }^{85}$ De 1983 a 1986 o Estado do Rio de Janeiro teve como governador Leonel Brizola. Para Caldeira (2005, p. 31) esse será o período da política penitenciária “a cada facção criminosa, sua unidade”, no qual as facções consolidaram o controle do espaço carcerário fluminense e das decisões ali tomadas. O então governador foi acusado de ter relações com o jogo do bicho e ser complacente com o crime organizado, ao proibir por exemplo, que as ações violentas dos policiais nas favelas.
} 
Comissões não significou uma transferência do poder do Estado para os presos, mas sim a legitimação e oficialização de um arranjo de poder que já vinha ocorrendo no sistema prisional.

Além do mais, seu sucesso enquanto medida de humanização dos presídios pode ser questionado pelo fato de que elas "não deram voz aos presos”, mas legitimaram o discurso e os interesses daqueles presos que já tinham voz. Esse arranjo de poder na prisão, assim como a legitimação da hierarquia entre os presos, pode ser ilustrado pela leitura de um dos objetivos da Comissão: “pacificar e conscientizar os demais presos”. Daí se depreende que haveria um grupo de presos esclarecidos, já pacíficos e conscientes, que teriam como função educar “os demais".

É natural que em um processo democrático sejam eleitos aqueles que já exerçam influência sobre os demais, porém a legitimação dessas lideranças, ao tirar a possibilidade de comunicação direta do preso com a Direção do presídio, impediu que os demais presos tivessem voz nas suas demandas, uma vez que a partir de então eles teriam aqueles que falariam em seu interesse. Como conseqüência, os problemas do estabelecimento prisional poderiam ser contemporizados e filtrados de acordo com os interesses dos presos membros da Comissão ${ }^{86}$ e da própria Administração prisional.

Apesar do sucesso das Comissões de Solidariedade poder ser questionado, no tocante a ter conseguido democratizar as relações estabelecidas no cárcere e dado voz àqueles que careciam dela, a sua criação teve impacto no curso da dinâmica prisional.

O Estado, ao institucionalizar o poder informal e reconhecer as lideranças dos presídios, legitimou o poder exercido pelos presos sobre os presos e diminuiu a tensão no cárcere. De acordo com a própria Comissão (a partir do relatório da Comissão Teotônio Vilela), houve uma redução (em termos de morte) da violência institucional:

\footnotetext{
${ }^{86}$ Quanto a este tema, agradeço aos ricos esclarecimentos do meu orientador, Alvino Augusto de Sá, que trabalhava no sistema prisional na época e presenciou a criação dessas Comissões, inclusive participando ativamente do processo enquanto “mesário” nas eleições diretas.
} 
"Segundo a Solidariedade, há uma relação entre o aumento do binômio 'Segurança e disciplina' e o aumento de motins, rebeliões, fugas e mortes. Assim, em 1974, ano de maior rigidez naquele binômio, morreram 24 presos e 1 guarda, enquanto, após 15 de março de 1984, com o surgimento da Comissão, somente se registrou uma única morte num camburão de transporte”

(CTV, 1984)

Porém, a criação das Comissões somada às outras medidas da política de humanização, teve um impacto negativo no contexto político da época, já que, simbolicamente, o Estado estava cedendo seu poder aos presos.

De acordo com Sykes (2007), a sociedade espera que os Administradores detenham o controle total sobre as prisões. Porém, essa exigência é paradoxal ao próprio funcionamento do sistema. O paradoxo está no fato de que a ordem maior do presídio é assegurada às custas de permitir algumas violações à norma. A incapacidade de coibir que os presos quebrem algumas regras do sistema não é uma falha temporária, mas é própria do sistema social da prisão (Sykes, 2007, p.62)

De qualquer forma, a chamada política de humanização não duraria muito. Já em 1986, com o lançamento do chamado "pacote de segurança” pelo Vice-Governador e candidato ao Governo Estadual Orestes Quércia, o setor reacionário do PMDB se sobressaiu ao setor mais progressista, levando a demissão do secretário José Carlos Dias (Góes, 2004, p. 222).

A demissão de Dias esteve diretamente ligada à grande repercussão da existência de um grupo organizado de presos denominado Serpentes Negras $^{87}$, cujo aparecimento foi atribuído à política leniente do então Secretário. Apesar de, posteriormente todas as sindicâncias e

\footnotetext{
${ }^{87}$ O Serpentes Negras foi o primeiro grupo de que se teve noticia a se organizar no Estado de São Paulo. Segundo Renato Laércio Talli (2001) -que foi corregedor da Secretaria de Administração Penitenciária entre abril e setembro de 2000 - o objetivo inicial desta organização era a melhoria das condições dos presos da Penitenciária do Estado. Somente depois, os Serpentes Negras assumiram o monopólio do tráfico de drogas nas prisões e começaram a praticar outros crimes.
} 
procedimentos apontarem em sentido contrário, qual seja: da não comprovação da existência da organização, os meios de comunicação deram ampla cobertura ao fato, sempre associando a existência da organização criminosa à política do então secretário da Justiça (Teixeira, 2006, p.86).

O endurecimento da questão penitenciária se consolida no uso do discurso público como saída legítima para lidar com essa nova ameaça que surge no sistema. Porém, a saída de José Carlos Dias e a vitória da política conservadora não corresponderam à ampliação do controle do sistema prisional pelo Estado. Conforme será analisado no próximo capítulo, a falta de uma política penitenciária clara e coesa, aliada à autonomia administrativa e disciplinar dada aos estabelecimentos prisionais, só aumentou a discricionariedade do poder administrativo e as violações dos direitos dos presos; conforme atesta Eda Góes:

“A partir das saídas do secretário Dias, as prisões paulistas voltaram a ser tradicionalmente gerenciadas, ou seja, cotidianamente administradas através de um conjunto de práticas e procedimentos que transitam entre o formal e o informal, com grande autonomia e sem nenhuma transparência, quer para os outros órgãos do Estado, quer para a sociedade civil.”

(Góes, 2004, p. 222)

A segunda chave teórica atribui o fortalecimento e expansão das facções pelo sistema prisional ao endurecimento da lei penal, principalmente a partir da edição da Lei dos Crimes Hediondos em $1990^{88}$, e ao aumento da violência institucional do sistema prisional. O emprisionamento em massa e a rigidez da política criminal, ao invés de ajudarem no combate desses grupos organizados, acabaram por unir os presos em torno deles. O aumento da repressão do sistema de justiça e da violência nas prisões criou um ambiente propício para que os presos se agregassem e se fortalecessem enquanto poder informal. Eles tinham em comum a necessidade de se proteger das arbitrariedades nas prisões e a revolta por se sentirem excluídos da sociedade, e vítimas do sistema de justiça.

${ }^{88}$ Este tema será aprofundado adiante, no Capítulo 5. 
Nesse mesmo sentido é a conclusão do WOLA (Washington Office on Latin America) no tocante às políticas de combate ao crime organizado na América Central, especificamente em Honduras, Guatemala e El Salvador. Segundo uma reportagem da organização (Wola, 2006, p. 5), as estratégias altamente repressivas adotadas por esses países (tal como encarceramento em massa da população jovem, duras sentenças e deportação dos imigrantes), conhecidas por políticas de mano dura, contribuíram para que os grupos se tornassem mais organizados.

De acordo com a reportagem, a tendência dos membros das gangues juvenis desses países foi reduzir sua exposição pública, e conseqüentemente o risco de ser identificado como ligado a alguma gangue e, provavelmente, preso; para tanto, eles têm evitado, por exemplo, grandes tatuagens e calças largas. Algumas precauções parecem ter sido recomendadas também por uma organização brasileira: um manual de procedimento do Comando Vermelho, descoberto pela polícia em 1994, contém recomendações de como se vestir e como andar ${ }^{89}$, precauções a serem tomadas a fim de evitar a ação do sistema punitivo.

Além das conseqüências de uma política criminal repressora, o aumento da violência e da arbitrariedade na gestão prisional foi um fator determinante para que as facções se estabelecessem naquele momento. Pela precisa análise de Alessandra Teixeira :

“.... a ausência e a insidiosa presença do Estado nos presídios (representadas fundamentalmente na corrupção e na truculência de suas gestões), bem como a exacerbação da violência e da tortura em estabelecimentos de excelência disciplinar como o Anexo de Taubaté os principais elementos que não apenas estiveram na base dos fenômenos que originou o PCC, mas que garantiram sua expansão e fortalecimento."

(Teixeira, 2006, p.133).

\footnotetext{
89 “8. Andar sempre bem apresentável, com barba feita. Evitar falar gíria. Evitar andar a pé. Não freqüentar lugares suspeitos. Não andar em companhia de chave de cadeia. 12. Não usar tatuagem em hipótese alguma” (fonte: Amorim, 2006, p.167).
} 
Para Adeildo Nunes ${ }^{90}$, os castigos físicos e morais impostos aos detentos pelo desumano sistema carcerário fizeram com que as facções surgissem, se aprimorassem e se expandissem nos presídios brasileiros. Nesse sentido, ele interpreta a frase de Marcola "Nós não suportamos mais tanta opressão e maus tratos" como um grito de alerta dos presos.

O Manual de Gerenciamento de Crises do Sistema Prisional elaborado pelo o Ilanud relaciona os incidentes prisionais ao desrespeito das regras por parte do Estado de Execução Penal:

. “... é preciso não perder de vista que o desrespeito dos presos pelas normas internas de disciplina nos estabelecimentos carcerários está diretamente vinculado ao sentimento generalizado que o próprio Estado descumpre freqüentemente as normas básicas de administração prisional. (...) Como exigir moralmente por parte dos presos a obediência a leis que o Estado mesmo éo primeiro a descumprir? Os incidentes prisionais são assim, em larga medida, $o$ reflexo deste desrespeito generalizado às regras de execução penal no Brasil."

(Ilanud, 1998, p.37)

O recrudescimento da disciplina e o aumento da violência e arbitrariedade na Execução penal no Estado de São Paulo puderam ser observados ainda em 1985, com a criação de uma prisão de segurança máxima anexa à Casa de Custódia e Tratamento de Taubaté (Piranhão).

O Piranhão ${ }^{91}$ apresentava uma rigidez disciplinar e um alto grau de violência institucional até então inéditos no sistema prisional. Conforme afirma o suposto líder do PCC, Marcola, em depoimento à CPI do Tráfico de Armas: "Porque a gente não tinha dignidade nenhuma em Taubaté na época (...). A gente era espancado mesmo, toda hora”.

\footnotetext{
${ }^{90}$ No painel As facções criminosas e seus desafios para execução penal do12 ${ }^{\circ}$ Seminário Internacional do IBCCRIM, realizado em 2006 na cidade de São Paulo.

${ }^{91}$ Segundo Percival de Souza (2006, p. 180), o nome Piranhão está associado à concentração em Taubaté dos "presos que nada a mais tinham a perder, não se intimidavam com ameaças de aumento de pena...”, e por isso denominados "piranhas". Segundo a reportagem de Fátima Souza (2007, p. 97), o anexo da Casa de Custódia de Taubaté é conhecido entre os presos também como "Campo de Concentração".
} 
A possibilidade de ser transferido para Taubaté atemorizava os presos, e aqueles que lá cumpriam pena amarguravam as violências sofridas. Não por acaso, foi justamente dentro do espaço projetado para punição e isolamento dos presos considerados os mais perigosos do sistema que surgiria oito anos mais tarde o PCC.

O surgimento da facção tem raízes no ódio despertado pelo tratamento repressivo. O sentimento de impotência de um homem sozinho (ou de indivíduos desorganizados) frente a esse sistema pode ter contribuído para que os presos se organizassem, aumentando desta forma o exercício do poder pelos presos.

O ódio dos presos pelo Piranhão chega aos dias de hoje. Conforme a redação do art. 14 do Estatuto do PCC, um dos principais objetivos do Partido seria a desativação do anexo da Casa de Custódia de Taubaté. “A prioridade do Comando no montante é pressionar o Governador do Estado a desativar aquele Campo de Concentração"anexo" à Casa de Custódia e Tratamento de Taubaté, de onde surgiu a semente e as raízes do comando, no meio de tantas lutas inglórias e a tantos sofrimentos atrozes”.

Assim como o PCC surge no presídio de maior rigidez disciplinar de São Paulo, o Comando Vermelho tem início no terrível presídio de Ilha Grande, como “forma de viver na adversidade” (Silva, 2001), conforme explica o jornalista Paulo Amorim:

“A prisão da Ilha Grande não negava ser uma das piores do mundo. Foi exatamente trabalhando sob essas inimagináveis condições de vida que ele (William da Silva) e seus companheiros conseguiram construir o alicerce de uma organização que se tornaria mais poderosa naquela ocasião que o próprio sistema penitenciário... A união de presos comuns para resistir ao clima geral de barbaridade no Instituto Penal Cândido Mendes tinha uma base objetiva: sobreviver. Para não morrer, para não ser roubado pelos grupos já existentes, para continuar vivendo como homem era preciso reagir. As falanges Jacaré, Coréia, zona Sul e os independentes comandavam a rotina de terror que dominava milhares de prisioneiros”.

(Amorim, 2006, p. 99) 
O Massacre do Carandiru, em 1992, é representativo do aumento da arbitrariedade e da violência no sistema prisional a partir da década de 1990. No dia 2 de outubro de 1992, a Casa de Detenção de São Paulo foi invadida por tropas da Polícia Militar, como reação a uma rebelião dos presidiários do pavilhão 9. A operação resultou na morte de 111 presos $^{92}$. As perícias revelaram que a grande maioria das mortes apresentava características de execução (tiros na cabeça e de cima pra baixo).

Para agravar a situação, o então diretor da Casa de Detenção, José Ismael Pedrosa, assassinado em 2005, foi transferido para o anexo da Casa de Custodia de Taubaté. A possibilidade de ingressar no regime duro do Piranhão, que era então dirigido pelo homem que estava no comando da prisão no momento da rebelião, criou novo fator de tensão no sistema prisional.

A ação policial ocorrida no Carandiru deflagrou a fragilidade dos presos em relação às ações violentas e arbitrárias do Estado. Até hoje aquele evento constitui um marco na luta dos presos contra os abusos institucionais. O próprio Estatuto do PCC $^{93}$ ressalta a necessidade de que os presos se mantenham organizados, a fim de evitar acontecimentos como aquele da Casa de Detenção.

Para Fernando Salla (2006), o massacre do Carandiru foi um marco na história do sistema prisional. A partir de então, a principal causa de morte no interior das prisões deixa de ser o conflito dos presos com a segurança, e passa a decorrer do conflito entre os próprios presos.

O sentido das rebeliões também sofreu mudanças no decorrer dos anos noventa: elas não vêm mais tendo o objetivo de obter mudanças ou expressar queixas. As rebeliões vêm ocorrendo geralmente em momentos em que a ordem fica suspensa (e por isso mesmo), e passaram a ser

\footnotetext{
${ }^{92}$ O número total de mortos só foi divulgado oficialmente no dia seguinte, meia hora antes do encerramento das eleições municipais.

93 Art. 13 do Estatuto "Temos que permanecer unidos e organizados para evitarmos que ocorra novamente um massacre semelhante ou pior ao ocorrido na Casa de Detenção em 02 de outubro de 1992, onde 111 presos foram covardemente assassinados, massacre este que jamais será esquecido na consciência da sociedade brasileira. Porque nós do Comando vamos mudar a prática carcerária, desumana, cheia de injustiças, opressão, torturas, massacres nas prisões"
} 
usadas pelos presos para acerto de contas (Salla, 2006). Os detentos aproveitam o clima do levante e invadem o seguro (onde geralmente estão os considerados inimigos da população carcerária) para acertar suas desavenças.

Um fenômeno muito comum nos últimos anos é o uso político da rebelião como meio de protesto contra a transferência de líderes da facção para regimes disciplinares rígidos ou para presídios que fiquem fora do Estado de São Paulo ${ }^{94}$. Nesse caso, o conflito nos estabelecimentos prisionais desafia as decisões tomadas no âmbito de política penitenciária e obriga o Estado a negociar seu poder com a facção.

As rebeliões, de qualquer forma, trazem à tona a precariedade das condições do cárcere e a incapacidade do Estado em garantir a segurança interna dos presídios. Além do mais, esses levantes são uma demonstração do poder informal dos presos, tão veementemente negado pelas autoridades públicas.

O PCC conseguiu agregar os presos em torno do discurso da defesa da solidariedade entre si, e da união contra os abusos do poder Estatal e as más condições dos cárceres. Com o dinheiro da caixinha (contribuição compulsória de cada membro do Partido, estando dentro ou fora das grades) e da realização de outros crimes, o PCC passou a suprir algumas necessidades básicas dos presos mais necessitados e de sua família.

Nesse sentido, o poder de unificação da massa carcerária se deu "não apenas pelo signo da violência e da coação, mas principalmente na ocupação de um espaço e no desempenho de funções que seriam pertinentes ao Estado, dentro das prisões” (Teixeira, 2006, p.132).

\footnotetext{
${ }^{94}$ Em junho de 2006, os presos de 40 unidades prisionais de São Paulo fizeram uma “rebelião branca”: passaram a recusar-se a comparecer às audiências judiciais em solidariedade aos lideres do PCC que estavam em RDD em Presidente Bernardes e Presidente Venceslau.
} 
"Dentro de um Sistema com tantas mazelas, dificuldades e carências já era de se esperar que grupos surgiriam com promessas de melhorias $e$ logo ganhariam adeptos junto a massa carcerária, agindo criminosamente, dentro e fora das prisões. Foi na ausência do Estado que essas organizações ganharam força dentro dos presídios, assim como o crime, antes desorganizado, se tornou organizado no Estado de São Paulo, isso também é resultado da falta de ação do Estado"

(Relatório CPI do Sistema Prisional, Lino, 2006)

Porém, para Sykes (2007), a mais grave conseqüência do emprisionamento não é a privação material, até porque algumas pessoas, extremamente carentes, encontram satisfação maior para as suas necessidades básicas na prisão do que fora dela. Ainda que o Estado atendesse a todas as necessidades básicas do preso (alimentação, vestuário, acomodação, lazer, etc.), o preso, como qualquer ser humano, tem desejos que vão além delas; tais como cigarro, bebidas, doces, o que Sykes denominou amenities. Hoje, quem proporciona tanto as necessidades básicas quanto às comodidades são as faç̧̃es.

Para Sykes (2007, p.81) faltaria justamente um comprometimento ideológico dos presos que transcendesse suas diferenças individuais. Apesar de este comprometimento coletivo poder ser questionado pelas práticas das facções criminosa, sua influência simbólica é indiscutível. A solidariedade é elemento recorrente no discurso desses grupos e é a partir dele que essas organizações exercem seu poder:

"Um dado fundamental para entender o modo pelo qual o núcleo que deu origem ao Comando Vermelho foi ganhando a confiança do conjunto dos prisioneiros: enquanto as demais falanges se organizavam em torno de seus próprios interesses - e geralmente pelo terror - o grupo do 'fundão' se esforçava para melhorar as condições carcerárias e reprimia o crime”.

(Amorim, 2006, p. 110) 
O fato das autoridades públicas negarem a existência do PCC também contribuiu para o seu fortalecimento. Apesar de se afirmar que o PCC surgiu em 1993, ele se assume publicamente em 1995 em rebelião do presídio de Hortolândia, quando os presos hastearam uma bandeira com a sigla da facção. A existência do PCC foi confirmada já em 1996 pela Comissão Parlamentar de Inquérito do Sistema Prisional, inclusive com a divulgação do chamado estatuto do PCC no Diário Oficial do Estado de São Paulo nesse mesmo ano. Mas o Estado negara a sua existência até a megarrebelião de 2001.

Somente após a megarrebelião no sistema prisional paulista, cuja dimensão e repercussão tomaram proporções tão grandes que a organização dos presos não poderia mais ser ignorada, é que o Estado começou a tratar com seriedade a questão.

\subsection{A lei e a ordem: soberania e disciplina}

“... a prisão (...) deve ser recolocada aí: no ponto em que se faz a torção do poder codificado de punir, em um poder disciplinar de vigiar; no ponto que os castigos universais das leis vêm aplicar-se seletivamente a certos indivíduos e sempre aos mesmos; no ponto em que a requalificação do sujeito de direito pela pena se torna treinamento útil do criminoso; no ponto em que o direito se inverte e passa para fora de si mesmo, e em que o contradireito se torna o conteúdo efetivo e institucionalizado das formas jurídicas”.

(Foucault, 2002, p.184)

Em Vigiar e Punir (2002), Foucault retratará as condições econômicas e sociais que permitiram e acompanharam mudanças na arte de governar, com o surgimento de uma nova racionalidade política e de um novo tipo de poder a partir do séc. XVII. Com o fim do Antigo Regime e o desenvolvimento da economia mercantil (e mais tarde do capitalismo industrial), 
houve um deslocamento e uma descentralização do poder absoluto do soberano para os mecanismos disciplinares.

O surgimento do poder disciplinar trouxe mudanças tanto no objeto e na forma de exercício do poder, quanto na própria forma de punição. O controle que até então era exercido pelo soberano sobre seu território passa a ser anônimo e ter como objeto a vida das pessoas, e a punição que era feita principalmente na forma de suplícios é substituída pela pena de prisão. O corpo suplicado e castigado dá lugar ao corpo corrigido.

Apesar das instituições disciplinares já existirem anteriormente, foi na modernidade que a disciplina se fixou como forma social do poder. Segundo Foucault (2002, p. 118), apenas no decorrer dos sécs. XVII e XVIII é que as disciplinas se tornaram formas gerais de dominação, expandindo sua ação para além das instituições de confinamento.

A soberania, caracterizada pela figura do soberano e por relações de dominação, foi a forma de poder que prevaleceu desde a Idade Média até o séc. XVI. O poder soberano era descontínuo e lacunar, tinha por objeto o território, não o individuo: não estava preocupado com a forma que a população vivia, mas apenas com o sucesso no exercício do confisco e do controle territorial.

Nesse momento, a prisão ainda não era a pena por excelência, os suplícios prevaleciam enquanto punição exemplar: agindo sobre o corpo dos súditos, impingindo-lhes um sofrimento calculado e público, com o intuito de exaltar o poder do monarca, reafirmando sua soberania sobre aqueles que se mostram inimigos do rei.

Porém, a violência impingida pelos suplícios, ainda que bruta e descomunal, não carecia de racionalidade. Ao contrário, é milimetricamente calculada, medida quantitativa e qualitativamente, proporcional ao mal cometido e organizada de forma ritualística, com o fim de assegurar a perpetuação do poder soberano sobre o indivíduo. A exemplaridade da punição, seu detalhamento, assim como sua inscrição no corpo, podem ser facilmente reconhecidos na descrição do mecanismo do rastelo no conto Na Colônia Penal de Franz Kafka: 
“- Nossa sentença não soa severa. O mandamento que o condenado infringiu é escrito no seu corpo com o rastelo. No corpo deste condenado, por exemplo - o oficial apontou para o homem- será gravado: Honra o teu superior!”

(Kafka,1996, p.13)

Contudo, com o fim do Antigo Regime, os suplícios darão lugar à prisão, elevando-a enquanto pena por excelência, enquanto uma forma racional e pura de punir, supostamente não-violenta, e por isso, compatível com os preceitos do Estado Moderno. As tintas fortes usadas pelo poder soberano e a centralização do poder na figura do monarca vão sendo substituídas pelas disciplinas, cujo exercício é anônimo e discreto, não situável em um espaço ou identificável com uma pessoa.

As mudanças sociais e o desenvolvimento econômico a partir do séc. XVII tiveram grande impacto na determinação dos bens jurídicos merecedores de tutela penal, assim como na forma de se pensar a punição. Com o surgimento de um novo tipo de riqueza (concentrada agora nas mercadorias estocadas nos armazéns e na maquinaria) o sistema punitivo passa a coibir outros tipos de conduta; e com o desenvolvimento de um novo tipo de economia, a punição na forma da prisão constituirá o principal meio de reforma das individualidades, adequando os indivíduos aos padrões de normalidade, adestrando-os para a ética do trabalho e empregando sua força produtiva para atender a demanda crescente de mão-de-obra.

A modernidade inaugura um novo tipo de poder, produtivo, que se exerce sobre a vida, governando as forças do corpo e dirigindo-as para determinados fins. Segundo Foucault esse poder sobre a vida - por isso denominado biopoder - desenvolveu-se sobre duas unidades distintas: primeiro em relação ao indivíduo, investindo sobre seu corpo; depois atingindo a população, enquanto corpo-espécie, com o controle dos processos da vida, da morte e das mudanças.

A partir do século XVII, consolidam-se os mecanismos disciplinares para extrair utilidade e docilidade dos corpos dos indivíduos, através da anatomia-política de seus corpos. O segundo pólo de atuação desse poder se desenvolve a partir da segunda metade do séc. XVIII, e centra- 
se no corpo-espécie, na população, regulando a natalidade, mortalidade, migração, habitação, configurando uma bio-política da população.

O poder soberano - diferentemente do poder disciplinar- não tinha por objeto a regulação das práticas cotidianas (Moura, 2007, p. 24). Um dos privilégios da soberania, o direito sobre a vida e a morte - o soberano fazia morrer ou deixava viver - foi substituído por um poder de causar à vida ou devolver à morte. Nas palavras de Foucault:

“A velha potência da morte em que se simbolizava o poder soberano é agora, cuidadosamente, recoberta pela administração dos corpos pela gestão calculista da vida”

(Foucault, 2005, p.131)

A disciplina como maneira de gerir a vida é colocada por Foucault na História da sexualidade, v. I, no capítulo intitulado Direito de morte e poder sobre a vida, como parte da tecnologia do biopoder. Este veio substituir o poder do soberano de causar a morte, por um poder de controle do corpo e da população, que tem como função produzir vida:

“As disciplinas do corpo e as regulações da população constituem os dois pólos em torno dos quais se desenvolveu a organização do poder sobre a vida. A instalação durante a época clássica, desta grande tecnologia - (...) caracteriza um poder cuja função mais elevada já não é mais matar, mas investir sobre a vida”.

(Foucault, 2005, p.131)

O desenvolvimento do biopoder acompanhou-se da valorização da normatividade e do controle ininterrupto visando a normalização. 
“um poder que tem a tarefa de se encarregar da vida terá necessidade de mecanismos contínuos, reguladores e corretivos.(...) um poder dessa natureza tem que qualificar, medir, avaliar, hierarquizar, mais do que se manifestar $e$ seu fausto mortífero "

(Foucault, 2005, p.135).

Enquanto as relações de soberania estariam mais ligadas ao âmbito da lei (sistemas jurídicos da soberania), o poder disciplinar se consolida no campo da norma, da regra normalizadora, que não se confunde com a lei, apesar de os preceitos jurídicos funcionarem como formas de tornar aceitável o exercício desse poder normalizador, legitimando os procedimentos de normalização:

\footnotetext{
“(...) o que não quer dizer que exista de um lado, um sistema de direito, sábio e explícito - o da soberania - e de outro, as disciplinas obscuras silenciosamente trabalhando em profundidade, constituindo o subsolo da grande mecânica de poder. Na realidade as disciplinas têm um discurso.”
}

(Foucault, 2004, p. 189)

\begin{abstract}
Além do poder disciplinar se respaldar no saber jurídico para a legitimação de seu exercício, ele mesmo constitui seu próprio discurso. Este não se encontra circunscrito no direito, mas se apóia no saber clínico o qual fixa os padrões de normalidade a partir da construção da figura do anormal. Apesar de sustentarem enunciados distintos, o saber disciplinar e o saber jurídico inserem-se no mesmo fluxo de poder, funcionando em relação de complementaridade
\end{abstract} (Foucault, 2004, p. 189).

O encontro dessas duas esferas, com a sobreposição da norma na lei, não anuncia o fim do aparato legal ou das instituições de justiça, mas, ao contrário, denuncia justamente a coexistência harmônica desses dois campos, a integração das leis aos contínuos aparelhos que envolvem questões reguladoras (Foucault, 2005, p.135). A estrutura jurídica, enquanto reguladora dos processos mais gerais, são interpenetradas pela capilaridade e particularidade 
do poder disciplinar, conformando assim o direito à norma. O saber da norma passa também a colonizar o campo da lei, formando um direito normalizado-normalizador.

O funcionamento mais perigoso do controle penal acontece à margem da legalidade, nas outras instituições da justiça criminal além do judiciário, tal como a polícia e a prisão. A execução da pena de prisão não se restringe tão somente à conseqüência da violação da lei penal, ela se constitui em uma realidade autônoma cujo alcance vai além da punição pela infração, agindo sobre o indivíduo com o objetivo de normalizá-lo: "na justiça penal a prisão transformava o processo punitivo em técnica penitenciária” (Foucault, 2002, p.247).

O alvo da punição deixa de ser o infrator (objeto da lei) e passa a ser o delinqüente (construção da disciplina). A transformação do infrator em delinqüente se dá a partir da ação de um poder que produz saberes e discursos de verdade. A biografia do delinqüente está a todo tempo construída e sua vida se constitui objeto de exame, a qual se deve "conhecer para controlar”.

A prisão situa-se no encontro da ordem jurídico-legal e da ordem institucional-disciplinar. Não há detenção senão jurídica, e não há sistema jurídico na modernidade que não esteja relacionado aos mecanismos de normalização. O papel jurídico da soberania na decretação da privação de liberdade acoberta a verdadeira razão da punição moderna: a constituição de indivíduos presos em certas subjetividades, docilizados, obedientes e úteis.

A prisão enquanto sistema disciplinar tem um mecanismo penal próprio, que abrange prescrições de comportamento e sanções para o seu descumprimento. A micropenalidade funciona na instituição disciplinar a partir de três instrumentos principais: do olhar hierárquico, da sanção normalizadora e do exame.

Foucault denominará os chefes e subchefes da Escola de Mettray (que para o filosofo é o marco da formação do sistema carcerário): “técnicos do comportamento: engenheiros da conduta, ortopedistas da individualidade” que exercem um “adestramento que é acompanhado por uma observação permanente; continuamente se avalia o comportamento 
cotidiano dos colonos; é um saber organizado como instrumento de apreciação perpétua" (Foucault, 2002, p. 244).

Como bem afirmou Foucault no texto Soberania e Disciplina, o direito da soberania e mecanismos disciplinares são partes intrinsecamente constitutivas dos mecanismos gerais de poder em nossa sociedade:

'Nas sociedades modernas, os poderes se exercem através e a partir do próprio jogo da heterogeneidade entre um direito público da soberania e o mecanismo polimorfo da disciplina"

(Foucault, 2004, p. 189)

Para ele, o erro está em querer limitar a discricionariedade e a violência calada do poder disciplinar a partir do revigoramento daquele poder soberano, na ilusão de que o exercício do poder legal possa ser igualitário, democrático e libertador, de que os homens e as instituições possam ser apreendidos e controlados justamente pelo direito.

"Creio, porém, que chegamos a uma espécie de beco sem saída: não é recorrendo à soberania contra a disciplina que os efeitos do poder disciplinar serão limitados, (...). Na luta contra o poder disciplinar, não é em direção do velho direito da soberania que se deve marchar, mas na direção de um novo direito antidisciplinar e, ao mesmo tempo, liberado do princípio da soberania”

(Foucault, 2004, p. 190). 


\section{CAPÍTULO 5}

\section{ORDEM FORMAL: DIREITO PENITENCIÁRIO}

Direito penitenciário ${ }^{95}$ é o direito de execução da pena de prisão. Ele conforma a ordem jurídica do cárcere e pode ser caracterizado por sua oficialidade, formalidade, e geralmente, enquanto uma produção estranha ao cárcere, ou seja, cujas normas são elaboradas extra-muros e aplicadas à realidade prisional.

Será denominada ordem formal a ordem jurídica do cárcere. Esta é composta pelo conjunto das normas e diretrizes oficiais, escritas, emanadas pelos órgãos estatais, sejam provindas do legislativo ou do executivo, incluindo o regulamento interno dos presídios.

Para Clemmer (1958, p.184) apesar das regras de funcionamento da instituição não serem leis, têm ao mesmo poder de coação das leis, já que são funcionários públicos os que determinam as regras, portanto representantes do Estado.

Com a promulgação da Lei 7210/84 (Lei de Execução Penal), a Execução Penal passou a ter caráter jurisdicional, deixando de ser mera atividade administrativa. Porém, como já mencionado anteriormente ${ }^{96}$, a dinâmica prisional continua regida muito mais pela lógica interna dos estabelecimentos do que pelos preceitos legais que os regulamentam, uma vez que o respaldo legal à execução penal não tem se mostrado efetivo na prática penitenciária.

Os motivos mais comumente atribuídos à inaplicabilidade da legislação no âmbito da execução penal estão relacionados às questões conjunturais próprias do sistema prisional: falta de estrutura física e de pessoal, falta de verba e vontade política, excesso de presos no sistema, alto grau de burocracia, omissão do judiciário devido ao grande volume de trabalho dos magistrados etc. Da mesma forma, o discurso da "falência da pena de prisão" se assenta em tais problemas conjunturais para justificar porque a prisão tem falhado, no decorrer dos anos, em alcançar seu objetivo.

\footnotetext{
${ }^{95}$ A LEP, nos itens 8 e 9 da Exposição de Motivos sugere a utilização do termo direito de execução penal, visto que direito penitenciário restringiria a matéria à problemática do cárcere, não abrangendo os outros tipos de pena e suas respectivas execuções. Como nessa pesquisa, trabalhar-se-á apenas com a pena privativa de liberdade, optou-se pela denominação mais restrita.

${ }_{96}$ Capítulo 4, item 4.3. Gerenciamento da dinâmica prisional: a legitimação das práticas.
} 
Assim como para Foucault o fracasso da prisão é próprio de seu funcionamento, pode-se dizer que a não aplicação da lei e dos preceitos jurídicos em matéria de execução penal, é um aspecto constitutivo do sistema normativo carcerário. Tanto em um (fracasso da prisão) como em outro caso (inobservância da lei em matéria de Execução), caberá à disciplina suprir a falibilidade do sistema, dando sentido à pena e regulando o dia-a-dia prisional. O poder disciplinar se consagra na dinâmica prisional por meio de mecanismos de poder afirmativos e práticas que irão preencher o vazio deixado naquilo que não está a alcance da lei.

O fracasso da prisão e a ineficácia do tratamento legal das questões do cárcere não podem ser atribuídos apenas às questões conjunturais. O insucesso tanto de um quanto de outro são aspectos estruturais do sistema punitivo: é justamente na imperfeição do sistema, na distância entre o ideal e o real, entre a lei e a norma, na chamada "zona cinzenta”, que é aberto espaço para o reinado da disciplina.

A disciplina, enquanto prática que escapa ao direito, é a função exercida pela pena na dinâmica interna dos presídios que excede o campo jurídico e ocupa os espaços deixados pela legalidade. Porém, apesar de ser denominada contra-direito, por desconstruir nas relações cotidianas a falácia jurídica que todos são iguais perante a lei (Foucault, 2002, p. 183), a disciplina co-existe harmonicamente com a ordem jurídica, quase em uma relação mutualística, na qual ambos tiram proveito e a existência de um depende da existência do outro. O direito aufere legitimidade para o funcionamento da disciplina, enquanto a disciplina dá conteúdo e materialidade ao direito:

\footnotetext{
“a margem pela qual a prisão excede a detenção é preenchida de fato por técnicas de tido disciplinar. E esse suplemento disciplinar em relação ao jurídico, é a isso, em suma, que se chama 'o penitenciário'.”
}

(Foucault, 2002, p. 208)

Para Foucault o penitenciário é o ponto de encontro entre o poder legal de punir e o poder técnico de disciplinar: "homogeneizando-os assim, apagando o que possa haver de violento em um e de arbitrário no outro (...) fazendo circular de um para o outro os mesmos métodos calculados, mecânicos e discretos” (Foucault, 2002, p. 250). 
Os regulamentos das instituições disciplinares podem ser tidos como uma nítida manifestação do carcerário, do lugar em que a lei encontra com a disciplina, normatizando a vida e suas manifestações, com o objetivo de manter a ordem e normalizar os que a transgridem:

\begin{abstract}
“O regulamento 'bebe' nas regras do Direito, ele as torna aplicáveis no interior dos lugares institucionais de tal forma que parece ser possível afirmar que Foucault pretende estabelecer uma linha de continuidade entre norma jurídica e norma disciplinar. O termo que faria a ligação entre ambas seria o regulamento. A substância dos regulamentos das instituições é composta pelas regras formais do Direito em sua interação com as normas disciplinares.”
\end{abstract}

(Santos, 2007, p. 11)

As normas jurídicas em âmbito de execução penal dificilmente apreenderão as nuances da dinâmica prisional, na medida em que o funcionamento da prisão está muito além da previsibilidade jurídica e a violência da pena não se limita à privação da liberdade. O exercício mais perigoso da prisão está no exercício do poder sobre a vida do condenando, justamente no ponto em que ela excede o direito e se consolida enquanto uma realidade autônoma.

\title{
5.1. Natureza do processo de execução
}

Os sistemas processuais podem ser classificados como inquisitórios, acusatórios ou mistos. O sistema inquisitório caracteriza-se pela identidade entre acusação e juízo: nesse sistema não há inexistência de regras que garantam igualdade entre as partes, e o órgão julgador concentra grande parte do poder, inclusive o de gerir as provas; por sua vez, o sistema acusatório pressupõe a publicidade do processo, a garantia do contraditório, que a parte dê início ao processo, e principalmente, que as funções de acusar, defender e julgar sejam exercidas por diferentes órgãos ou pessoas, garantida a isonomia entre as partes. Já o sistema misto seria caracterizado por ter uma fase inquisitória seguida de outra acusatória. 
A Lei de Execução Penal - LEP (Lei 7210) surge em 1984 para por fim, ao menos formalmente, a uma longa tradição administrativa-inquisitorial do processo de execução penal brasileiro, conforme previsão expressa do art. 194: “O procedimento correspondente às situações previstas nesta Lei será judicial, desenvolvendo-se perante o Juízo da Execução.”

A jurisdicionalização da execução, somada à observância das garantias do sistema processual acusatório, funcionariam como limite ao arbítrio estatal em sede de execução penal; avocando-se, inclusive, o princípio da legalidade para evitar que os "desvios ou excessos na execução comprometam a dignidade e humanidade do direito penal”, conforme a exposição de motivos $n^{\circ} 12$ e o artigo 45 da Lei.

Pela primeira vez no Brasil a questão disciplinar recebeu tratamento legal. A LEP instituiu direitos e deveres dos presos; delimitou expressamente as faltas disciplinares graves e suas respectivas sanções (inclusive com a proibição do uso da cela escura); atribuiu competências aos órgãos de execução penal; e submeteu o processo disciplinar e a dinâmica prisional ao controle do juiz da execução. Desta maneira, este instrumento jurídico limitou, ao menos formalmente, a discricionariedade da administração na execução da pena privativa de liberdade.

Apesar da pena privativa de liberdade estar limitada à sentença penal condenatória, os chamados incidentes prisionais ${ }^{97}$ podem levar a alterações nesses limites, seja quantitativamente (diminuir o tempo de pena a cumprir, ou aumentá-lo em virtude do cometimento de um novo crime), seja qualitativamente (mudanças no regime de cumprimento de pena e outras mudanças quanto à forma de cumpri-la). Dessa forma, a progressão e regressão de regime, as saídas temporárias, a concessão do surcis e sua revogação, a concessão da liberdade condicional e sua revogação, a remição da pena e a perda dos dias remidos pelo cometimento de falta grave, assim como as outras conseqüências da

\footnotetext{
${ }^{97}$ Aqui, como no decorrer do Capítulo, o termo incidente prisional é utilizado no sentido de um acontecimento que perturba a dinâmica do cárcere: "Sob a denominação incidentes prisionais estão contidos, na verdade, fenômenos bastantes diferentes, nem sempre discerníveis em ocasiões concretas. Dentro do conceito estão compreendidos: I) fugas, evasões e tentativa de fuga; II)movimentos reivindicatórios; III)motins ou rebeliões.” (Ilanud, 1998, p. 16,17) . Neste caso, o termo não tem o mesmo sentido que os incidentes de execução previstos no Titulo VII da LEP, que abrange: conversão de pena, excesso ou desvio de execução, anistia e indulto.
} 
responsabilização por falta disciplinar, além de alterar a medida e a forma da privação da liberdade, atingem outros direitos individuais não atingidos pela sentença.

Daí a necessidade de jurisdicionalização e controle do procedimento penal executório, uma vez que a Constituição Federal prevê que nenhuma lesão ou ameaça de direito ficará fora de apreciação pelo poder judiciário (artigo $5^{\circ}$, inc. XXXV). Logo, caberia ao legislativo regular e limitar os atos da administração penitenciaria, e ao judiciário o seu controle, em respeito ao princípio da separação dos poderes e a manutenção de seu equilíbrio.

A atribuição de caráter jurisdicional à execução penal é inconteste, e se evidencia na leitura do texto legal e na exposição de motivos da lei, que prevêem, por exemplo, que: "vencida a crença histórica de que o direito regulador da execução é de índole predominantemente administrativa...” (exposição de motivos $\mathrm{n}^{0}$ 10), “não haverá falta nem sanção disciplinar sem expressa e anterior previsão legal ou regulamentar” (princípio da legalidade - art. 45 da LEP) e ainda, “o procedimento correspondente às situações previstas nesta Lei será judicial, desenvolvendo-se perante o Juízo da Execução” (art. 194 LEP).

Porém, a prática penitenciária, e mesmo a estrutura do processo disciplinar previsto na LEP, são revestidos de traços inquisitoriais, pondo em cheque o sistema acusatório do processo de execução. Com a distância do judiciário da realidade carcerária e a falta de um procedimento disciplinar acusatório, as garantias previstas no texto federal ficam longe de poderem ser observadas na prática. Para Salo (2007, p. 419) a sistematicidade inquisitória da LEP carece de instrumentalidade mínima para concretização dos direitos ali previstos, ainda que a lei fosse cumprida na integralidade, a estrutura processual inquisitória impossibilitaria a verdadeira efetivação daqueles direitos. 
A seguir, serão elencadas algumas características do sistema de execução que limitam o pretenso caráter jurisdicional da Execução Penal no Brasil:

\title{
A) Inexistência de controle jurisdicional na Execução Penal
}

\author{
"o procedimento administrativo de apuração de faltas disciplinares e de \\ aplicação das respectivas sanções não sofre qualquer espécie de ingerência \\ jurisdicional, tornando toda e qualquer decisão judicial mero consectário da \\ vontade administrativa"
}

(Roig, 2005, p. 168)

O ordenamento jurídico brasileiro é revestido de formalidade e legalismo, e composto de diplomas legais muito bem arquitetados que não encontram muita ressonância na prática, tal como o Estatuto da Criança e Adolescente, a LEP e a própria Constituição Federal.

O controle jurisdicional previsto na LEP não vai muito além do texto legal. Na prática penitenciária, o juiz faz mero juízo homologatório da decisão da autoridade administrativa. O art. 54 da LEP evidencia essa tendência, ao dispor que as sanções de advertência verbal, repreensão, suspensão ou restrição de direitos e de isolamento, "serão aplicadas por ato motivado do diretor do estabelecimento".

\begin{abstract}
Além do mais, as visitas dos magistrados aos estabelecimentos prisionais previstas na LEP estão longe de saírem do papel. Pelo texto da lei, o juiz deveria participar ativamente na execução das penas, com visitas ao menos mensais ao estabelecimento prisional (artigo 66, inc. VII da LEP), com o intuito de inspecionar o estabelecimento e a administração do presídio, e supervisionar o cumprimento da pena; da mesma maneira, o Ministério Público é incumbido de fiscalizar a execução da pena, inclusive oficiando no processo executivo e nos incidentes da execução (artigo 67 da LEP).
\end{abstract}




\section{B) Concentração das funções acusatória e de julgamento}

O juiz da Execução Penal concentra os papéis de acusação e julgamento, comprometendo a imparcialidade do julgado e a igualdade entre as partes. A separação das funções é uma das principais características que diferem o modelo acusatório do inquisitório.

O modelo acusatório pressupõe passividade do juiz na iniciativa da ação penal e na produção das provas ${ }^{98}$. Porém, o texto da LEP concebe a figura do juiz ativo na execução, que age sem necessidade de provocação, como, por exemplo, na decretação da revogação da liberdade condicional (art. 143), no início da execução da pena de prisão (art. 147) e na imposição da medida de segurança (art. 183). Além do mais, de acordo com o arts. 59 e 60 da LEP, os procedimentos para se apurar as infrações disciplinares são instaurados pela autoridade administrativa competente.

\section{C) Ausência de defesa técnica}

No processo de conhecimento no juízo penal, a falta de defesa técnica é causa de nulidade absoluta no processo. Já no processo de execução, o “processado” não precisa estar representado por advogado. É prática comum no cotidiano prisional que o próprio preso pleiteie seus direitos, peticionando diretamente ao juízo de execução.

A falta de defesa técnica que acompanhe o processo de execução compromete a ampla defesa e o exercício do contraditório. Ainda que o processo de execução fosse de cunho administrativo, de acordo com o art. $5^{\circ}$, inc. LV, CF, é garantido a todo litigante (ainda que em processo administrativo) a ampla defesa e o contraditório com todos os meios e recursos a ela inerente, inclusive o direito do litigante produzir provas.

\footnotetext{
${ }^{98}$ Ainda que pelo principio da verdade real, que rege o direito processual penal brasileiro, o magistrado seja dotado de autonomia para produzir as provas que julgar necessárias.
} 
D) Administrativização da apuração das faltas e na aplicação das respectivas sanções

O art. 59 da LEP prevê a instauração, de acordo com o regulamento, de procedimento administrativo para apurar a falta disciplinar, assegurado o direito de defesa e a motivação da decisão. A possibilidade da Administração do estabelecimento apurar e sancionar infrações disciplinares, sem qualquer interferência judicial, compromete a jurisdicionalidade do procedimento disciplinar.

Além do mais, cabe à autoridade administrativa aplicar, sem controle jurisdicional, algumas das sanções disciplinares previstas no art. 53, e até decretar o isolamento preventivo do preso pelo prazo máximo de 10 dias (art. 60).

\section{E) Falta de definição legal dos conceitos e clareza no texto da lei}

A vagueza de alguns conceitos da LEP permite que lhes sejam atribuídos diversos significados, em contrariedade ao principio da legalidade. $\mathrm{O}$ fato de que quem irá interpretar e dar materialidade à lei é a Direção do estabelecimento prisional, e não o magistrado, somente reforça a natureza administrativa da execução penal.

Embora haja um elenco legal das faltas graves, o juízo quanto à intensidade de cada uma delas cabe exclusivamente à autoridade administrativa. A falta de precisão dos termos e conceitos faz com que muitos sentidos possam ser atribuídos à lei. Cabe à Administração prisional a análise da gravidade do fato, podendo inclusive aplicar o isolamento preventivo.

Segundo Schmidt (2007, p. 48), há poucos casos de faltas leves e médias no sistema prisional, pois a vagueza do dispositivo que estabelece a gravidade da falta permite que qualquer desvio de conduta possa ser considerado falta grave. Ele relata, a partir de sua experiência como Conselheiro Penitenciário do Estado do Rio Grande do Sul, como a polissemia do texto legal, especificamente do inc.I do art.50 da LEP - que prevê que comete falta grave aquele que incitar ou participar de movimento para subverter a ordem ou a disciplina - permite que uma ampla gama de comportamentos possa ser interpretada como "atentadora" da ordem e disciplina: 
“... tive noticias em que apena dos foram enquadrados nessa falta grave (e, conseqüentemente, foram postos em isolamento celular além do que não puderam, durante 12 meses receber 'benefícios' como comutação, indulto, livramento condicional) porque colocaram-se em greve de fome em protesto contra o não-deferimento de sua remoção(...) ou contra a morosidade da Justiça. Noutra situação um preso foi punido porque se recusou a cortar os cabelos...”

(Schmidt, 2007, p. 48)

\section{F) Preso enquanto objeto da execução penal}

A jurisdicionalização da execução penal revestiu a aplicação da pena privativa de liberdade com algumas garantias, e abriu alguns canais para o preso exercer o direito de voz, assumindo a condição de sujeito de sua execução (por exemplo, a possibilidade de audiência pessoal do preso com o diretor do estabelecimento prisional). Porém, os abusos no cotidiano prisional e a própria logística do procedimento disciplinar não permitem a efetivação dos direitos previstos na legislação federal e constitucional, e a efetiva participação do apenado enquanto sujeito da execução.

A execução da pena é caracterizada por excessivo subjetivismo, à medida que as decisões quanto aos incidentes prisionais não se orientam por critérios técnicos, mas puramente utilitários, visando à manutenção da ordem (Roig, 2005, p. 14) e do arranjo na distribuição dos poderes.

A administração do cotidiano prisional segue a lógica dos castigos e privilégios retratada por Goffman (1974). Além do mais, a punição, enquanto inserida no jogo de poder entre a administração e massa carcerária, faz com que ao resultado de grande parte dos processos disciplinares seja a condenação.

Outro fator de tensão entre a Administração do presídio e a massa carcerária é a incerteza quanto à sua condição jurídica. Esta incerteza é responsável pela angústia de muitos presos, 
que ficam sem informação de seu processo e, o que é mais grave, sem meios de obtê-la, devido à ausência de defensor acompanhando a Execução Penal. Nesse sentido, a inclusão do inciso X ao artigo 66 da LEP pela Lei 10.713/03 que prescreve, entre as competências do juiz da execução, a emissão anual de atestado de pena a cumprir.

Uma efetiva jurisdicionalização em âmbito da Execução reduziria o domínio da discricionariedade da Administração Penitenciária. Para tanto, é imprescindível a inafastabilidade do controle jurisdicional a qualquer lesão ou ameaça aos direitos dos presos. Roig (2005, p. 173) sugere, inclusive, a criação de autênticos tipos disciplinares como garantia do preso, e limite legal ao poder administrativo.

Porém, como já mencionado, o exercício de poder na prisão ocorre justamente nas brechas deixadas pela lei. Seu funcionamento mais perigoso é no que excede a privação da liberdade e os limites da previsibilidade e segurança jurídica. Por isso, almejar que a lei funcione controlando todo o cotidiano prisional significa questionar a própria estrutura de funcionamento da prisão, um arranjo harmônico entre os poderes legal e disciplinar, que vem sido mantido há mais de dois séculos.

\subsection{Competência Normativa}

No inc. I do art. 24, a Constituição Federal previu ao legislador estadual a competência concorrente com a União para legislar sobre o direito penitenciário. Ao Poder Legislativo Federal cabe dispor acerca das normas gerais, enquanto aos Estados e ao Distrito Federal, a partir das suas particularidades e necessidades, compete legislar supletivamente e elaborar regulamento para a execução penal.

A Lei de Execuções Penais (Lei 7210/84), é a principal referência legislativa nacional em Execução Penal. Nela estão previstos os direitos e deveres do preso, assim como os órgãos de execução penal e as suas competências. Quanto à competência sobre as faltas disciplinares, a lei dispõe que cabe aos Estados dispor sobre as faltas leves e médias e as respectivas sanções, 
enquanto a União tem competência exclusiva para legislar quanto às faltas consideradas graves (conforme previsto no art. 49).

Segundo o item 78 da Exposição de Motivo da Lei 7.210/84, cada estabelecimento prisional tem a competência pra elaborar um código disciplinar e poder para executá-lo. No Estado de São Paulo, a Secretaria de Administração Penitenciária (SAP) publicou o Regimento Interno Padrão dos Estabelecimentos Prisionais do Estado de São Paulo, com o objetivo de uniformizar os procedimentos da Execução Penal paulista, assim como as normas disciplinares de seus estabelecimentos prisionais.

Além do Regimento Interno Padrão, a SAP regulamenta a Execução Penal por meio de suas Resoluções, as quais dispõem acerca da gratificação dos servidores, doações, constituição de comissões, e ainda medidas disciplinares ${ }^{99}$ e procedimentos administrativos a serem adotados pela Administração Penitenciária paulista.

A seguir, serão analisados esses principais instrumentos de regulação da Execução Penal (os quais, em conjunto, constituiriam o chamado direito penitenciário): as normas constitucionais aplicadas à Execução Penal, a própria Lei de Execução Penal e sua recente reforma, além do Regimento Interno Padrão e algumas das Resoluções editadas pela Secretaria de Administração Penitenciária. Serão analisadas também particularmente a Lei dos Crimes Hediondos (8.072/90) e a lei que instituiu o Regime Disciplinar Diferenciado (10.792/03), por terem introduzido importantes mudanças no curso da Execução Penal, e causado grande impacto na conformação do sistema prisional.

De forma a situar essa produção normativa no contexto de alguns dos principais acontecimentos no sistema prisional paulista, segue abaixo uma breve cronologia:

- 1984 Edição da Lei de Execuções Penais

- 1985 Criação da unidade prisional de segurança máxima anexa à Casa de Custódia de Taubaté, conhecido pela massa carcerária como Piranhão

\footnotetext{
${ }^{99}$ Por exemplo, o Regime Disciplinar Diferenciado (RDD) foi criado e regulamentado por uma Resolução da SAP (n 26/01), o tratamento legal do regime especial só ocorreria posteriormente, com a edição da Lei $10.792 / 03$.
} 
- 1988 Promulgação da Constituição Federal

- 1990 Edição da Lei dos Crimes Hediondos

- 1992 Massacre do Carandiru

- 1993 Criação da Secretaria de Administração Penitenciária de São Paulo (SAP/SP)

- 1993 Fundação do Primeiro Comando da Capital (PCC)

- 1995 Rebelião na Casa de Detenção de Hortolândia e na Penitenciária I de Tremembé

- 1997 Política de interiorização dos presídios

- 2000 Início da política de desativação das Carceragens dos distritos policiais e da Casa de Detenção de São Paulo (Carandiru)

- 2001 Megarrebelião

- 2001 Criação do Regime Disciplinar Diferenciado pela Resolução 26 da SAP

- 2001 (maio) Divisão da Coordenadoria de Estabelecimentos Prisionais do Estado de São Paulo (Coesp), com a criação de cinco Coordenadorias Regionais e uma especializada na questão da saúde do preso

- 2002 (março) “Operação Castelinho”, 12 supostos integrantes do PCC foram metralhados por policiais do Gradi em um pedágio na Rodovia Castelo Branco

- 2002 (setembro) Desativação da Casa de Detenção de São Paulo (Carandiru)

- 2003 (março) Assassinato do juiz corregedor de Presidente Prudente Antonio José Machado Dias

- 2003 (dezembro) Reforma da Lei de Execuções Penais pela Lei 10.72/03 com instituição legal do RDD 
- 2006 (maio) Rebelião em 73 presídios do Estado. Quatro dias de ataques a bases e distritos policiais, bem como a agências bancárias e ônibus, atribuídos ao PCC

- 2006 (agosto) Seqüestro do repórter da Rede Globo e transmissão do vídeo do PCC no Plantão da emissora

\subsection{Garantias Constitucionais aplicadas à Execução Penal}

São garantias constitucionais aplicadas à Execução Penal:

. respeito à dignidade humana como fundamento da República (art. 1º III, CF);

. individualização das penas e a isonomia (Art. $5^{\circ}, \mathrm{XLV}, \mathrm{CF}$ ); separação dos presos, diferentes regimes de cumprimento, condições para progressão e regressão, possibilidade de indulto, saída temporária etc.

- proibição da pena de morte, salvo nos casos de guerra declarada, bem como penas perpétuas; de trabalhos forçados, de banimento ou cruéis (Art. 5º XLVII, CF);

. respeito à sua integridade física e moral do preso (Art. 5º XLIX, CF), com proibição da tortura, tratamento desumano ou degradante (Art. $5^{\circ}$, III, CF);

. direito ao devido processo legal "ninguém será privado da liberdade ou de seus bens sem o devido processo legal” (Art. 5, XLIX, CF);

. a ampla defesa e o contraditório a todos os litigantes, em processo judicial ou administrativo, com todos os meios e recursos a ela inerentes (Art. $5^{\circ}, \mathrm{LV}, \mathrm{CF}$ );

. direito à liberdade de consciência e de convicção religiosa (art. 5º VI, VII, VIII, CF)

. direito ao sigilo de correspondência e das comunicações telegráficas, de dados e telefônicas (art. $5^{\circ}$, XII, da CF);

. direito à assistência judiciária (art. 5 XXXIV, da CF); 
. direito à indenização por erro judiciário ou por prisão além do tempo fixado na sentença (art. $\left.5^{\circ}, \mathrm{LXXV}, \mathrm{CF}\right)$;

\subsection{Lei de Execução Penal}

"A despeito de alguns avanços, não se verifica, substancialmente uma ruptura em relação ao modelo penitenciário tradicional, calcado no discricionarismo administrativo, no cientificismo etiológico e na arraigada visão positivista da pena".

(Roig, 2005, p. 139)

Nos fim dos anos setenta e início dos oitenta as sociedades européias vêem a derrocada do Estado de bem-estar social e o surgimento de uma nova racionalidade no âmbito penal (enfraquecimento do exercício disciplinar e fortalecimento dos mecanismos de controle). Paradoxalmente, nesse mesmo período no Brasil, a questão carcerária ganha relevo pela presença de presos políticos no sistema prisional, seguida da concessão de anistia. (Teixeira, 2006).

No contexto de redemocratização e fortalecimento dos movimentos sociais, as concepções acerca da prisão são pautadas pelo ideal humanitário e ressocializador. Estas concepções têm no texto da LEP a sua tradução jurídica, e na implementação da "política de humanização dos presídios” seu reflexo prático.

Como já mencionado, A Lei de Execução Penal (Lei 7210/94) foi criada para jurisdicionalizar a Execução Penal no Brasil, estabelecendo regras jurídicas fundamentais ao regime penitenciário, tanto em relação à disciplina do preso quanto aos limites da atuação estatal.

Conforme a exposição de motivos da lei ( $\left.\mathrm{n}^{0} 7\right)$, não teria sentido sustentar um Código Penal unitário, para todas as unidades da Federação, concomitantemente a uma legislação de 
Execução Penal regional, visto que o cumprimento da pena ou da medida de segurança não se dissocia do direito penal.

A LEP dispõe, em seu artigo $1^{\circ}$, que a Execução Penal visa efetivar as disposições da sentença. A sentença condenatória faz coisa julgada material, e forma título executivo, que servirá de parâmetro e limite à execução de pena (apesar de esses poderem ser alterados, com a ocorrência dos chamados incidentes da execução). Já o artigo $3^{\circ}$ da LEP garante ao condenado todos os direitos não atingidos pela sentença ou pela lei.

Porém, em análise mais apurada, verifica-se a impossibilidade da aplicação plena das disposições iniciais da lei, pois o funcionamento da prisão e seu êxito estão justamente além dos limites jurídicos. Mais do que privar de liberdade, a prisão atua na vida do apenado como um todo e institui desigualdades discricionariamente, cujo controle escapa, propositadamente, ao direito.

A seguir será desenhado o tratamento dado pela LEP às principais em matéria de Execução Penal.

\section{$\underline{\text { A) Direito dos presos }}$}

A LEP consagra nos artigos 40 a 43 os direitos do preso, como meio de "evitar a fluidez e as incertezas resultantes do conceito vagos ou omissos” (Exposição de motivos n ${ }^{\circ} 75$ ).

Toda realidade é fluída, complexa e escapa ao domínio legal. Contudo, à medida que muitas das leis não se materializam, tornando-se normas meramente programáticas, cresce o abismo entre o ser e o dever ser. Tratando-se do cárcere, esta distância parece ainda maior: a ordem legal não dá conta do que ocorre intra-muros, que aliás, pode ser melhor compreendido a partir da dinâmica interna do estabelecimento, do que pelo ordenamento jurídico que o regula.

Logo, apesar dos direitos dos presos estarem formalmente garantidos pela lei, muito pouco é observado na prática. Inclusive sua própria natureza jurídica de direito público subjetivo (Roig, 2005) é pouco reconhecida, visto que são por vezes denominados “benefícios” ou mesmo “regalias”. 
São direitos dos presos, segundo a LEP:

- alimentação, vestuário e instalações higiênicas alojamento (arts. 12 e 41, I);

- dispor de instalações e serviços que os atendam em suas necessidades pessoais, além de locais destinados à venda de produtos e objetos pessoais permitidos e não fornecidos pela administração (art. 13);

- cuidados e tratamento médico-sanitário em geral, conforme a necessidade (art. 14, § 2º);

- trabalho remunerado (arts. 28 a 37 e 41, II);

- previdência social (art. 41, III);

- constituição do pecúlio (art. 41, IV);

- proporcionalidade na distribuição do tempo de trabalho, descanso e recreação (art. 41, V);

- exercício das atividades profissionais, intelectuais, artísticas e desportivas, desde que c compatíveis com a execução da pena (art. 41, VI);

- assistência material, à saúde, jurídica, educacional, social e religiosa (art. 41, VII);

- proteção contra qualquer forma de sensacionalismo (art. 41, VIII);

- entrevista pessoal e reservada com seu advogado (art. 41, IX);

- visita do cônjuge, da companheira, de parentes e amigos em dias determinados (art. 41, X);

- chamamento nominal (art. 41, XI);

- igualdade de tratamento salvo quanto à individuação da pena (art. 41, XII);

- audiência especial com o diretor do estabelecimento (art. 41, XIII);

- representação e petição a qualquer autoridade, em defesa de direito (art. 41, XIV); 
- contato com o mundo exterior por meio de correspondência escrita, da leitura e de outros meios de informação que não comprometam a moral e os bons costumes (art. 41, XV);

- atestado anual de pena a cumprir (art. 41, XVI).

\section{B) Deveres do preso}

São deveres dos presos, de acordo com a LEP:

- comportar-se disciplinadamente e cumprir fielmente a sentença (art. 39, inc. I);

- obedecer ao servidor e respeito a qualquer pessoa com quem deva se relacionar (art. 39, inc. II);

- urbanidade e respeito no trato com os demais condenados (art. 39, inc. III);

- conduta oposta aos movimentos individuais ou coletivos de fuga ou de subversão à ordem ou à disciplina (art. 39, inc. IV);

- execução do trabalho, das tarefas e ordens recebidas (art. 39, inc. V);

- submissão à sanção disciplinar imposta (art. 39, inc. VI);

- indenização à vítima ou aos seus sucessores (art. 39, inc. VII);

- indenização ao Estado, quando possível, das despesas realizadas com sua manutenção (art. 39, inc. VIII);

- higiene pessoal e asseio da cela ou alojamento (art. 39, inc. IX);

- conservação dos objetos de uso pessoal (art. 39, inc. X);

Ademais, $\mathrm{O}$ art. 44 parágrafo único determina que todos os presos (definitivos e provisórios) estão sujeitos à disciplina, que "consiste na colaboração com a ordem, na obediência às determinações das autoridades e seus agente e no desempenho do trabalho”. 
Alguns desses dispositivos, dependendo de como forem executados, parecem ir além da finalidade geral de ordenar a convivência prisional, para intervir diretamente na vida do apenado, limitando sua já escassa autonomia. Aqui, mais uma vez, a vagueza do texto legal permite que sua interpretação seja dada de acordo com os interesses e critérios da Administração Prisional. Pode-se questionar, por exemplo, em que consistiria a obediência ao servidor ou qualquer outra pessoa a quem deva se relacionar? Esta obediência pressupõe que o preso não encare o funcionário? Quanto ao trato com os demais condenados, quem determinaria em que consiste a unidade: a lógica da massa carcerária ou da Administração? Como o Estado pode determinar os critérios de higiene pessoal? É preciso estar de barba feita e cabelo cortado para estar limpo? Ademais como o Estado pode obrigar a conservação dos objetos de uso pessoal se os mesmos forem de propriedade do apenado?

A exigência de observação desses deveres, assim como do respeito à disciplina da prisão, são representativos do controle ilimitado da vida do preso, que atinge outros direitos não limitados pela condenação, cuja preservação é garantida inclusive constitucionalmente.

Tais deveres compõem o exercício do poder disciplinar, à medida que o sistema determina a postura que o indivíduo deve ter na Execução da pena. O sucesso disciplinar pressupõe a docilização do preso: que ele aceite as normas, a hierarquia interna, execute o que lhe foi designado, e inclusive se oponha aos movimentos de outros internos que busquem a liberdade (art. 39, inc. IV). A lei determina como o preso deve interagir com aqueles que se relaciona (incs. II e III) e até como deve ser o trato pessoal e de seus pertences (IX e X); requerendo do preso uma postura passiva (art. 39, inc. IV e VI) e obediente (incs. I, II e V). Normatiza-se a interação social na tentativa de fixá-la, sacrificando seu caráter imprevisível e fluído; impondo uma forma de ser ao indivíduo e as formas como se relacionar. 


\section{C) Faltas disciplinares}

A competência para determinação das faltas leves e médias, bem como suas respectivas sanções foram atribuídas ao legislador local ${ }^{100}$, de forma a contemplar as particularidades de cada região. Enquanto a LEP determinou o rol de faltas graves com suas respectivas sanções.

São faltas graves ${ }^{101}$, segundo a LEP (art. 50):

I - incitar ou participar de movimento para subverter a ordem ou a disciplina;

II - fugir ${ }^{102}$;

III - possuir, indevidamente, instrumento capaz de ofender a integridade física de outrem;

IV - provocar acidente de trabalho;

V - descumprir, no regime aberto, as condições impostas;

VI - inobservar os deveres previstos nos incisos II e V do artigo 39 desta Lei.

E, ainda de acordo com o art. 51, comete falta grave o condenado à pena restritiva de direitos que:

I- descumprir, injustificadamente, a restrição imposta;

II - retardar injustificadamente, o cumprimento da obrigação imposta;

III - inobservar os deveres previstos nos incisos II e V do artigo 39 desta Lei ${ }^{103}$.

\footnotetext{
${ }^{100}$ No Estado de São Paulo, elas estão previstas no Regimento Interno Padrão elaborado pela da Secretaria de Administração Penitenciária, o qual será analisado a seguir.

${ }^{101}$ Para uma análise profunda e critica do texto da LEP, e, especificamente quanto a redação e sentido das faltas disciplinares: Roig, 2005, p. 142 e ss.

${ }^{102}$ No caso de fuga violenta, já que, em teoria, a simples evasão sem violência não é castigada, visto que seria natural para o individuo desejar e buscar a liberdade;

103 Art. 39. Constituem deveres do condenado:

II - obediência ao servidor e respeito a qualquer pessoa com quem deva relacionar-se;

$V$ - execução do trabalho, das tarefas e das ordens recebidas; 
O art. 52 ainda prevê enquanto falta grave a prática de fato previsto como crime doloso, sujeita tanto a sanção disciplinar, quanto à conseqüente sanção penal.

Apesar do intuito da LEP reduzir as margens do poder administrativo, a construção vaga e polissêmica da lei contribuiu para a manutenção da discricionariedade administrativa, cujo exercício a partir de 1984 passou a contar, ainda, com o respaldo legal.

A falta grave é equiparada à prática de um fato definido como crime, que justifica a regressão de regime de cumprimento de pena, e implica na transferência do condenado a um regime mais rigoroso, conforme dispõe o art. 118, inc. I da Lei. Por isso, o parágrafo único do art. 48 obriga a autoridade administrativa a representar ao juiz da execução para que este decida acerca da conversão de regime.

D) Procedimento inquisitório e discricionariedade da aplicação da sanção disciplinar

“Atualmente, a aplicação de uma sanção disciplinar (advertência verbal, repreensão, suspensão ou restrição de direitos, isolamento ou inclusão no regime disciplinar diferenciado) não afeta apenas o cotidiano carcerário do indivíduo punido. A própria função dos direitos públicos subjetivos da execução penal (chamados benefícios, como se o estado prestasse um favor aos indivíduos - livramento condicional, progressão de regime, comutação de pena, indulto, etc..) está intimamente atrelada ao comportamento satisfatório do condenado, remetendo-nos mais uma vez à ancestral problemática da discricionariedade da autoridade penitenciária”

(Roig, 2005, p. 20)

Com a vagueza da norma na aplicação de sanções disciplinares, o preso fica ao arbítrio da Direção do estabelecimento. O art. 59 conferiu aos regulamentos penitenciários dos Estados o poder de fixar ritos próprios conforme a particularidade da unidade federativa. Adiante, tratarse-á particularmente da organização penitenciária do Estado de São Paulo, assim como de sua produção normativa. 


\subsection{Secretaria de Administração Penitenciária: história e resoluções ${ }^{104}$}

Até 1979 os estabelecimentos destinados ao cumprimento de penas privativas de liberdade no Estado de São Paulo estavam subordinados ao Departamento dos Institutos Penais do Estado DIPE, pertencente à Secretaria da Justiça.

Com o objetivo de padronizar as unidades prisionais em relação à administração e segurança, é criada a Coordenadoria dos Estabelecimentos Penitenciários do Estado - COESPE, pelo decreto $\mathrm{n}^{0} 13.412$ de 1979, que veio a substituir o DIPE, que à época contava com 15 unidades prisionais.

Logo, até 1991 as unidades prisionais ficaram sob responsabilidade da Secretaria da Justiça. A partir de março de 1991, a responsabilidade foi transferida para a Secretaria de Segurança Pública, com quem ficou até 1993, quando é criada a Secretaria de Administração Penitenciária pela Lei 8209/93.

São Paulo foi o primeiro Estado no Brasil a ter uma Secretaria para tratar com exclusividade das questões penitenciárias. Dez anos depois, o decreto n 32.621 de 2003 institui no Estado do Rio de Janeiro a SEAP (também Secretária de Administração Penitenciária), com o intuito de tratar especificamente dos assuntos envolvendo o cárcere.

Até 1999, as cadeias públicas de São Paulo eram de responsabilidade da Secretaria de Segurança Publica, quando foram transferidas para o gerenciamento pela SAP. Atualmente a SAP administra 144 unidades prisionais distribuídas pelo Estado de São Paulo, com uma população de aproximadamente 150 mil presos.

As muitas resoluções editadas pela SAP regulamentam diversas matérias, entre as quais estão: doação de bens móveis aos estabelecimentos prisionais, gratificação pro labore do servidor, elogio aos servidores, criação de comissões para tratar de acontecimentos especiais (fuga /rebelião), criação de grupos de trabalho, aplicação de medidas administrativas na gestão do presídio etc.

\footnotetext{
${ }^{104}$ Informações obtidas no site da SAP www.sap.sp.gov.br
} 
A leitura das Resoluções, se confrontadas com o momento histórico do período de sua edição, ajuda a visualizar a tomada de posição do Executivo frente às demandas penitenciárias. Foram objetos das Resoluções a proibição do telefone celular, a regulamentação ao direito de visita, o uso de uniforme, a política de interiorização dos presídios (1998), a desativação das carceragens e da Casa de Detenção (2000), a criação do Regime Disciplinar Diferenciado (2001).

\subsection{Regimento interno padrão dos estabelecimentos prisionais do Estado de São Paulo}

O Regimento interno padrão dos estabelecimentos prisionais do Estado de São Paulo foi instrumento de uniformização de procedimentos, bem como de regras disciplinares, de 63 unidades prisionais do sistema paulista, formulado pela Secretaria de Administração Penitenciária, sob gestão do então secretário João Benedito de Azevedo Marques, e instituído pela Resolução SAP 27/ $1999^{105}$.

A partir dos princípios gerais da LEP e das Regras Mínimas para Tratamento dos Presos da ONU, o Regulamento objetivou "facilitar e valorizar o trabalho dos funcionários, respeitando ao mesmo tempo direitos à cidadania e à dignidade do preso".

O Regulamento consagra, enquanto objetivo da pena, a reintegração social e ressocialização do preso. Em seu art. $4^{\circ}$, inc. II, dispõe que o regime de segurança máxima deve obedecer a segurança interna que preserve os direitos do preso, a ordem e a disciplina. Evidenciando mais uma vez a intenção do sistema prisional de conciliar objetivos tão contraditórios: a ressocialização e a manutenção da ordem dos estabelecimentos.

A seguir serão analisadas algumas matérias de que trata o regulamento.

${ }^{105}$ Disponível no site da FUNAP www.funap.sp.gov.br/legislacao/manual/Manual_de_proc_reg_interno.pdf acesso dia 21/11/2007 


\section{A) Fases da execução da pena}

O art. $9^{\circ}$ dispõe que a execução administrativa da pena se dará em duas fases: período de inclusão e observação (30 dias), seguido do desenvolvimento do processo de execução da pena, compreendendo o processo de várias técnicas profissionais e de evolução sócio-educativas.

A inclusão deverá seguir, de acordo com o art. 13, os procedimentos de revista, higienização corpórea, identificação civil, troca do vestuário pelo uniforme padrão, entrega dos objetos e valores cuja posse não seja permitida pelo regulamento mediante inventário e contra recibo.

A segunda fase seria acompanhada pela Comissão Técnica de Classificação (CTC) ${ }^{106}$, então responsável por avaliar a terapêutica penal $e$ pela proposição das promoções subseqüentes (art. $10)$.

\section{B) Remoção do preso a outra unidade prisional}

A remoção do preso a outra unidade prisional pela Administração Superior poderia ocorrer, segundo o art. 16 do Regulamento: por solicitação do diretor da unidade, conforme indicação da Comissão Técnica de Classificação e demais áreas de avaliação; no caso de doença; ou por interesse da Administração, com vistas à manutenção da ordem, segurança e disciplina. Em qualquer dos casos, a decisão não passa pelo juiz das execuções penais, o qual deve ser apenas comunicado da transferência.

O Regulamento prevê ainda, duas situações em que o preso, seu procurador ou sua família, podem requerer a remoção pra outra unidade prisional (art. 17, inc. I e II): por conveniência (quando a família comprovadamente for da região que se pretende transferir); e quando

\footnotetext{
106 A Lei 10.792/03 responsável pela reformulação da Lei de Execuções Penais, modificou a competência da Comissão Técnica de Classificação em sede de Execução Penal. Foram retiradas do art. $6^{\circ}$ da LEP a previsão de acompanhamento da execução das penas pela CTC e a necessidade de parecer elaborado pela mesma Comissão quanto a progressão e regressão de regime. Hoje pela nova redação a principal atribuição das CTCs consiste em elaborar programa individualizador da pena.
} 
necessária a aplicação da Medida Preventiva de Seguro Pessoal (MPSP) ${ }^{107}$ e a unidade prisional não dispuser de recursos para administrá-la. Está entre os direitos dos presos solicitar a MPSP, como previsto no art. 23, inc. XXIV.

A unidade prisional pretendida deverá manifestar-se em 30 dias quanto ao pedido já instruído com motivos da transferência, atestado de saúde, conduta; inclusive com possibilidade de permuta de presos entre as unidades (arts. 19 e 20).

\section{C) Direitos e deveres do preso}

O capítulo 3 do Regulamento trata dos direitos, deveres, bens e valores, recompensas e regalias do preso em sede de Execução Penal. O art. 23 prescreve os direitos do preso, em consonância com o já previsto na Lei de Execução Penal, dentre os quais; a preservação da individualidade do preso, com direito ao chamamento nominal e uso do número de matrícula apenas para qualificação em documentos penitenciários (inc. I); peticionar à direção da unidade e demais autoridades (inc. XX); trabalho remunerado segundo sua aptidão (inc. IX); acesso aos meios de comunicação social - televisão, jornal, revistas, livros, sessões teatrais e cinematográficas etc. (inc. XVII); direito de ser informado sobre as normas a serem observadas nas unidades prisionais (inc. XXXIX).

O art. 27 prescreve os deveres do preso com o fim de garantir a ordem e disciplina do estabelecimento. Algumas exigências, dentre as previstas nos 39 incisos, parecem difíceis de serem cumpridas, por contrariarem o padrão de conduta exigido pela massa carcerária, como abster-se de movimento individual ou coletivo de tentativa ou consumação de fuga (inc. VI) e abster-se de liderar, participar ou favorecer movimentos de greve e de subversão da ordem e da disciplina (inc. VII). Em outras, fica claro a ação discricionária do poder administrativo, como no caso da obrigação de submeter-se a revista pessoal de sua cela e pertences a critério da administração (inc. XIII). Em outras, ainda, nota-se a necessidade da Administração

\footnotetext{
${ }^{107}$ Essa medida consiste na transferência do preso para o "seguro” (ou “amarelão”). Local da prisão destinado aos presos que não podem ficar na "convivência", no pátio, pois correm risco de vida. Motivos para um preso ir para o seguro: dívida, natureza do crime (crimes sexuais e contra crianças), caguetagem, desentendimento com a facção etc.
} 
prisional sobrepor-se a hábitos já consolidados pelos detentos, como abster-se de usar sua cela como cozinha (inc. XXVI).

\section{D) Elogio e regalias}

O art. 30 estabelece como recompensas o elogio e a concessão de regalias. Recompensa-se o preso pelo seu bom comportamento, sua colaboração com a disciplina e sua dedicação ao trabalho (art.29). E ainda, de acordo com o art. 31, a "prática de ato excepcional de relevância humanitária ou do interesse do bem comum” será merecedora de elogio, consignado em portaria do diretor da unidade prisional.

Dentre as regalias previstas no art. 32 estão: receber bens de consumo, bens patrimoniais trazidos pelos visitantes (“jumbo”); visitas íntimas; assistir shows, peças de teatro, cinema; assim como sessões de jogos esportivos fora do horário normal. Além das previstas nesse artigo, outras poderão ser acrescidas de forma progressiva conforme disposição do art. 33.

\section{E) Disciplina}

O art. 36 reforça a necessidade da observação do princípio da legalidade na aplicação de sanção disciplinar, ao prever que "não haverá sanção disciplinar sem expressa e anterior previsão legal e regulamentar”. Já os arts. 45 e 49 dispõem sobre a atribuição de competência sobre as faltas disciplinares e suas respectivas sanções. As sanções decorrentes das faltas graves merecem tratamento federal e estão previstas pela LEP, enquanto as decorrentes das faltas médias e leves, de competência Estadual, encontram-se no Regulamento.

$\mathrm{O}$ art. 37 veda as manifestações individuais ou coletivas que tenham o objetivo de reivindicação. Essa proibição viola manifestamente a liberdade de associação e manifestação asseguradas pelo art. $5^{\circ}$ da Constituição Federal, respectivamente nos incisos XVII e IV, já que a reivindicação consistiria em um fim lícito para a reunião, protegida, portanto, pelo preceito constitucional. Além do mais, proibir esse direito representa medida contrária à 
afirmação do preso enquanto sujeito de sua Execução, situação que pressupõe que este tenha direito a voz e participação.

\section{F) Faltas leves e médias}

Os arts. 47 e 48 enumeram as faltas leves e médias, que claramente consistem em regras do cotidiano prisional para regular o modo que o preso deve se comportar no dia-a-dia.

Tais regras, apesar de formalmente regulamentadas, aproximam- se mais da disciplina (do campo da norma) do que do direito (campo legal), já que elas constituem justamente os pequenos dispositivos disciplinares, cuja função é regulamentar “os detalhes mais finos da existência” (Foucault, 2002, p. 164).

Segundo Foucault (2002, p.172), a disciplina fixa, imobiliza ou regulamenta os movimentos. Da leitura desses dispositivos regulamentares, depreende- se que é essa mesma a sua intenção: garantir a ordem e o controle do estabelecimento prisional a partir da limitação da liberdade do preso, na tentativa de tornar tudo padronizado e previsível, contornando assim as dificuldades e riscos da interação de muitas individualidades num meio fechado e repressivo.

Algumas medidas podem ser compreendidas pela própria necessidade da Administração garantir o controle e a disciplina, como as proibições de: trânsito indevido dos presos; comportamento ou vestimenta considerados inadequados; posse de objeto não autorizado pela administração; uso de aparelho celular etc. Porém, entre as faltas leves e médias, incluem-se proibições que parecem sacrificar desproporcionalmente os direitos individuais em nome da “manutenção da ordem do cárcere” - expressão ampla de conteúdo vago pela qual todas as limitações se justificam. Por exemplo, consistem faltas médias de acordo com o art. 48: divulgar notícia que possa perturbar a ordem ou a disciplina (inc. VI); praticar auto-lesão como ato de rebeldia (inc. VIII); provocar perturbações com ruídos e vozerios ou vaias (inc. IX). Tais previsões são abusivas, uma vez que o ordenamento constitucional não pune a autolesão, e garante a liberdade de expressão. Além do mais, essas ações, comuns a qualquer ser 
humano, não parecem representar ameaça tão grande à ordem a ponto de terem de ser proibidas e sancionadas.

\section{G) Procedimento Disciplinar}

O funcionário que tomar conhecimento da prática de alguma falta disciplinar de qualquer natureza redigirá a “Comunicação de Evento”. Trata-se de uma espécie de "boletim de ocorrência prisional”, que deverá conter nome, número de matriculas dos envolvidos, local e hora da ocorrência, rol de testemunhas, hora e local dos fatos e descrição minuciosa do ocorrido. Uma vez preenchida a comunicação, o funcionário deverá encaminhá-la ao seu superior imediato (art. 54), que instalará sindicância para apurar o ocorrido a cargo de comissão designada por portaria do diretor da unidade prisional (art. 55).

O preso deverá tomar conhecimento da sindicância, garantido o direito de defesa técnica e produção de provas, com o acompanhamento dos atos pelo defensor dativo ou constituído (art. 55 , $\S \S 1^{\circ}$ e $3^{\circ}$ ), inclusive com a previsão da nomeação de defensor ad hoc para os atos em que o defensor deixar de comparecer (art. 55, § $2^{\circ}$ ). Ao final da apuração, será elaborado um relatório pela comissão. Este será encaminhado a quem lavrou a portaria, abrindo-se prazo para a defesa apresentar suas alegações finais (art. 55, § $5^{\circ}$ ). Os autos serão então encaminhados ao Conselho Disciplinar (composto pelo diretor da unidade em conjunto com 4 representantes das áreas de segurança e disciplina, administração, produção e centro de reabilitação) que se manifestará acerca do enquadramento do preso (art. 55, § 6), e, em seguida, ao diretor de disciplina para que este proponha ao diretor da unidade a aplicação de sanção em virtude da constatação da falta, ou o arquivamento do procedimento (art. 55, § 8, alinhas a e b ).

O procedimento disciplinar deverá ser instaurado por portaria, em 5 dias da data do conhecimento do fato, e será concluído em no máximo 30 dias (art. 59). 
A aplicação da sanção disciplinar em caso das faltas leves e médias será proposta pelo diretor da unidade prisional (art. 61). A decisão final será cientificada ao preso, e cópia da sindicância encaminhada ao juiz corregedor dos presídios (art. 64, inc. I e III).

Cabe ressaltar que a classificação da conduta disciplinar do preso entre ótima, boa, regular e má, a qual servirá de critério para a concessão de “benefícios” (como a progressão de regime segue o critério de tempo de não cometimento de infração disciplinar). Assim o preso do regime fechado que não cometeu infração grave ou média em 1 ano, tem sua conduta classificada como ótima; boa se não a cometeu em 6 meses; regular se cometeu falta grave em 30 dias ou média em 3 meses; e, má se cometeu nova falta durante o período de reabilitação de falta anterior (art. 68, incs. I, II, III e IV).

\subsection{Lei dos Crimes Hediondos}

“A atividade legislativa da década de 90, potencializada pelo conjunto de normas constitucionais programáticas, ampliou as hipóteses de criminalização e enrijeceu o modo de execução das penas, na grande maioria das vezes indo além do permitido constitucionalmente. O resultado desta experiência legiferante foi a dilatação do input e estreitamento do output do sistema carcerário.”

(Carvalho e Freire, 2007, p.271)

A Constituição Federal autorizou no artigo $5^{\circ}$ XLIII o tratamento mais severo para os crimes considerados hediondos ${ }^{108}$, assim como para a prática da tortura, o tráfico ilícito de

\footnotetext{
108 São considerados hediondos de acordo com o art. $1^{\circ}$ da Lei 8.072/90: “todos tipificados no Decreto-Lei $n{ }^{o}$ 2848 de 7 de dezembro de 1940, Código Penal, consumados ou tentados : I- homicídio (art. 121), quando praticado em atividade típica de grupo de extermínio, ainda que cometido por um só agente, e homicídio qualificado (art. 121, $2^{\circ}$, I, II, III, IV e V); II - latrocínio (art. 157, $3^{\circ}$, in fine); III - extorsão qualificada pela morte (art. 158, $2^{\circ}$ ); IV-extorsão mediante seqüestro e na forma qualificada (art. 159, caput e $1^{\circ}, 2^{\circ}, 3^{\circ}$ ); Vestupro (art. 213 e sua combinação com o art. 223, caput e parágrafo único); VI - atentado violento ao pudor (art. 214 e sua combinação com o art. 223, caput e parágrafo único); VII- epidemia com resultado morte (art. 267, $1^{\circ}$ ); VII-A - vetado; VII-B - falsificação, corrupção, adulteração ou alteração de produto destinado a fins terapêuticos ou medicinais (art. 273, caput, e $1^{\circ}$., $1^{\circ}$ A, $1^{\circ}$ B, com a redação dada pela Lei $n{ }^{\circ}$ 9.677, de 2-7-
} 
entorpecentes e o terrorismo, que são insuscetíveis de graça ou anistia. Porém, somente com a promulgação da lei 8072/90 a matéria foi regulamentada.

A Lei 8.072 surge nos anos 90 como um marco da reorientação da política criminal no Brasil (Teixeira, 2006, p. 96), no contexto em que a opinião pública clamava por um aumento da repressão, em virtude da ampla repercussão que alguns crimes tiveram na mídia e conseqüentemente na sociedade brasileira. Os seqüestros de dois grandes empresários, um em São Paulo (Abílio Diniz) e outro no Rio de Janeiro (Roberto Medina), impulsionariam a imposição de um tratamento mais duro para alguns tipos de crimes considerados graves. A princípio, o delito de homicídio havia ficado de fora do rol dos crimes considerados hediondos. Porém, em 1992, em virtude da ampla publicidade do assassinato de uma atriz e da campanha de sua mãe (ambas da rede de televisão Globo), o homicídio passou a constar na lista de crimes hediondos.

A Lei dos Crimes Hediondos é o que se poderia chamar, literalmente, de legislação de emergência. Quinze dias após o seqüestro de Roberto Medina estava aprovada a Lei. O então deputado José Genoino chegou a pedir vistas do projeto, mas foi chamado pelo deputado Roberto Jeferson, relator do projeto, de defensor dos traficantes e assassinos (Piazzon, 2006).

Podem ser consideradas medidas de enrijecimento penal previstas na lei: incremento da quantidade de pena; proibição de progressão de regime; aumento do lapso para livramento condicional e impedimento do indulto; e comutação de pena. Essas medidas, se analisadas em conjunto, significavam uma coisa: mais presos por mais tempo nas prisões.

Talvez o impacto maior da lei na dinâmica prisional tenha sido a proibição de progressão de regime aos condenados por crimes hediondos. A partir de então, independentemente da postura desse preso no cumprimento da pena, o seu “comportamento carcerário”, ele cumpriria toda a sua pena em regime fechado. O requisito subjetivo para a progressão de regime deixava de ser um meio de controle disciplinar do indivíduo. O Diretor do estabelecimento perdia uma carta importante no jogo de castigos e prêmios da Execução Penal.

1998). Parágrafo único. Considera-se também hediondo o crime de genocídio previsto nos arts. $1^{\circ}, 2^{\circ}$, e $3^{\circ}$ da Lei $n^{\circ} 2889$, de $1^{\circ}$ de outubro de 1956, tentado ou consumado”. 
A previsão de que a pena por crime hediondo devia ser integralmente cumprida em regime fechado (art. $1^{\circ}$, inc. II da lei) foi objeto de ampla discussão nos Tribunais ${ }^{109}$.

O aumento do número de presos por mais tempo no regime fechado - agravado pela falta de perspectiva e esperança de melhora na condição dos condenados por crime hediondo, trouxe sérias conseqüências para o sistema prisional.

Desde a promulgação da Lei de Crimes Hediondos, a população carcerária no Brasil sofreu significativo aumento, assim como os índices de criminalidade. Claro que não se pode atribuir esse aumento à promulgação da lei, mas se o objetivo do endurecimento da legislação de Execução Penal era a diminuição do número de delitos, esse resultado esteve longe de ser alcançado.

É o que mostra o estudo do Ilanud - Instituto Latino Americano das Nações Unidas para Prevenção do Delito e Tratamento do Delinqüente - em pesquisa publicada em 2002 e nomeada “A Lei de Crimes Hediondos como Instrumento de Política Criminal”.

A pesquisa foi feita com base em entrevistas a presos e funcionários do sistema penitenciário, a partir das quais se constatou que a Lei de Crimes Hediondos não inibiu a prática criminosa. Os presos, apesar de terem consciência do impacto da lei na situação processual, declararam que o texto rigoroso da lei não era empecilho para o cometimento de um novo crime. Tais declarações foram comprovadas pela pesquisa, que constatou que o condenado por crime hediondo, quando regressa ao sistema, é quase sempre pela prática de novo crime hediondo.

\footnotetext{
109 A doutrina e jurisprudência debateram por muitos anos a constitucionalidade do parágrafo $1^{\circ}$, do artigo $2^{\circ}$, da Lei 8.072/90, até que o Supremo Tribunal Federal decidiu em fevereiro de 2006 em um julgamento de Habeas Corpus pela inconstitucionalidade da proibição da Lei dos Crimes Hediondos dos condenados obterem progressão de regime durante o cumprimento da pena. E, finalmente, em 29 de março de 2007 foi publicada a Lei 11.464/07 que alterou a redação do art. $2^{\circ}$ da Lei 8.072/90, para admitir a progressão de regime prisional quando se tratar de condenação por crime hediondo e seus equiparados (tortura, tráfico ilícito de entorpecentes e drogas afins e terrorismo). O novo $\S 1^{\circ}$, do art. $2^{\circ}$ da Lei dos Crimes Hediondos, diz que a pena, por tais crimes será cumprida inicialmente em regime fechado, enquanto o $\S 2^{\circ}$ do mesmo artigo, estabelece a quantidade que deve ser cumprida da pena, para a progressão do regime (2/5 para condenados primários e 3/5 para reincidentes). Ademais o inc. II do mesmo art. $2^{\circ}$, também foi modificado pela nova lei; pela antiga redação os crimes hediondos e seus equiparados eram insuscetíveis de fiança e de liberdade provisória, com a modificação do mencionado inciso, tais crimes continuam insuscetíveis de fiança, mas não de liberdade provisória. O inciso I do art. $2^{\circ}$ não foi modificado, logo tais crimes continuam insuscetíveis de graça, anistia e indulto.
} 


\subsection{Regime Disciplinar Diferenciado}

O Regime Disciplinar Diferenciado (RDD) surge como resposta do Estado de São Paulo à megarrebelião ${ }^{110}$ ocorrida na capital paulista em fevereiro de $2001^{111}$, a qual envolveu trinta e cinco unidades prisionais da SAP e quatro cadeias sob responsabilidade da Secretaria de Segurança Pública.

A criação de um regime especial atende a uma finalidade específica: isolar e neutralizar as lideranças dos grupos considerados perigosos pelo sistema de justiça, enquanto "perturbadores da disciplina interna do presídio ou suspeitos de pertencerem a organizações criminosas”, de forma a evitar novos levantes, como o que ocorreu em 2001, que deflagrou o alto grau de organização e capacidade de comunicação dos presos de diversas unidades prisionais.

O regime consiste basicamente no confinamento do preso em uma pequena cela individual, com sérias limitações às possibilidades de interação social e à realização de atividades. Dentre as restrições do regime estão: a supressão de qualquer atividade educativa, laboral ou recreativa (o preso é condenado ao ócio); as limitações das possibilidades de comunicação do preso, tanto em âmbito interno (o regime legal prevê a saída da cela por duas horas para o banho de sol), quanto externo, com relação às pessoas de fora do espaço prisional. A lei restringe o contato dos presos com seus familiares (visitas semanais de duas pessoas - sem contar as crianças, com duração de duas horas) e até mesmo com os advogados (necessidade de pré-agendamento para entrevistar-se com o defensor). $\mathrm{O}$ isolamento somado à inatividade combinação que caracteriza o RDD- pode ser tida como um grande risco à saúde mental daqueles submetidos ao regime.

\footnotetext{
${ }^{110}$ O levante seria resposta à transferência dos lideres do PCC para o Anexo da Casa de Custódia de Taubaté, de regime disciplinar rígido, conhecido como Piranhão. Algumas particularidades dessa rebelião: teve início num domingo (dia de visitas, considerado sagrado para os presos); os presos, de inicio, não estavam denunciando más condições dos cárceres; e, ainda, contou com cobertura ao vivo das redes de televisão.

${ }^{111}$ O enrijecimento da política criminal a partir de 2001 não pode ser atribuído somente a megarrebelião, o então Secretário da Administração Penitenciária Nagashi Fukorawa em entrevista a Teixeira (2006, p.144) chama atenção para alteração na conjuntura política na época: com a morte de Mario Covas e a entrada de Geraldo Alckmin no governo paulista, as medidas de cunho mais progressistas que estavam sendo tomadas em sede de execução penal (ideal de ressocialização, participação comunitária, construção de unidades menores) ficaram em segundo plano, visto que o governo que sucedeu não tinha o mesmo compromisso com tais medidas que o anterior.
} 
Além do isolamento das outras pessoas (o preso não tem contato físico nem com suas visitas), o preso é isolado do ambiente, da vida. O fato das celas não terem janelas, terem pouca entrada de ar, e ainda, produzirem uma sensação térmica de calor contrastada com a frieza do cimento e da solidão, são elementos que afetam a forma do individuo vivenciar o Regime Disciplinar Diferenciado. As restrições formais do regime são materializadas e agravadas pelo tipo de construção arquitetônica dos estabelecimentos que o impõem. Conforme descrição do feita por João de Barros em reportagem do Le monde diplomatique ${ }^{112}$ :

"Regime Disciplinar Diferenciado (RDD): cela individual de seis metros quadrados com uma pequena fresta para entrada de ar. Cama de cimento, vaso sanitário e chuveiro com ducha de água fria. No verão, a temperatura ultrapassa os 40 graus. Duas horas de sol por dia e duas horas para as visitas semanais de duas pessoas, sem contato físico, separado por grades, telas ou vidros. Nem rádio, nem televisão, somente a leitura é permitida"

De 2001 até 2003, o regime foi regulamentado por Resoluções editadas pela Secretaria de Administração Penitenciária (Resolução 26/01, 50/01, 95/01 e 121/03). Em dezembro de 2003, entrou em vigor a Lei 10.792/03, que introduziu o Regime Disciplinar Diferenciado no texto da Lei de Execuções Penais, uniformizando sua aplicação e estendendo sua abrangência ao âmbito federal.

Inicialmente, o RDD foi instituído em cinco unidades prisionais: Penitenciária I e II de Presidente Venceslau, Penitenciária de Iaras, Penitenciária de Avaré e Casa de Custódia de Taubaté. Em 2002, a Resolução SAP 59, institui em Hortolândia o denominado Regime Disciplinar Especial (RDE), aplicável também aos presos provisórios.

\footnotetext{
112 “Uma radiografia do PCC” Le monde diplomatique -Brasil, dezembro de 2006 http://diplo.uol.com.br/2006-12,a1461, acesso 5/01/2008
} 
Além da experiência paulista, o Rio de Janeiro criou o Regime Disciplinar Especial de Segurança, a partir da rebelião de Bangu I em dezembro de 2002, liderada por Fernandinho Beira- Mar, suposto líder do Comando Vermelho.

Em 2003 o Centro de Adaptação de Presidente Bernardes foi criado exatamente para o fim da aplicação desse regime especial, enquanto a Penitenciária I e II de Presidente Venceslau e a Penitenciária de Iaras deixaram de aplicar o RDD.

A seguir, serão analisados os instrumentos legais que criaram e regulamentaram o Regime Disciplinar Diferenciado a partir de 2001.

\section{A) Resolução SAP 26/01}

O Regime foi, inicialmente, instituído pelo poder executivo paulista por meio da Resolução 26/01 da SAP, que criou uma categoria de isolamento celular diversa da prevista no artigo 58 da LEP (de duração máxima de 30 dias), a qual seria aplicável "aos líderes e integrantes das facções criminosas" e "aos presos cujo comportamento exija tratamento específico" (art. $1^{\circ}$ da Resolução).

O tempo máximo de permanência no regime era de 180 dias, na primeira inclusão, e 360 nas demais (art. $4^{\circ}$ da Resolução), sem limite para a re-inclusão, desde que pautada em fatos novos ou na insistência da prática dos mesmos atos que motivaram a primeira inclusão (art. $7^{\circ}$ ).

O diretor técnico de qualquer unidade poderia solicitar, mediante petição fundamentada, a remoção do preso para o Regime Disciplinar Diferenciado. O pedido era endereçado ao coordenador regional das unidades prisionais que, se estivesse de acordo, faria o encaminhamento ao secretário-adjunto, a quem caberia a decisão final (art. $2^{\circ}$ da Resolução).

Por esse procedimento, o juiz da Execução Penal seria somente comunicado, no prazo de 48 horas, da inclusão ou da exclusão do sentenciado (art. $8^{\circ}$ da Resolução). Logo, antes da regulamentação do regime pela Lei 10.792/03, a decisão sobre a inclusão no regime especial cabia à autoridade administrativa, com mera comunicação ao juiz da Execução Penal. Essa previsão desrespeitava a natureza jurídica da Execução Penal, principalmente por se tratar de 
uma decisão cujo teor poderia modificar por completo a forma de cumprimento da pena, conforme ensina Alberto da Silva Franco:

“trata-se de um procedimento burocrático interno, em nível penitenciário, para a aplicação de uma sanção disciplinar que modifica, por completo, o próprio regime prisional.”

(Franco, 2003, p.2)

O poder de tal decisão foi atribuído ao diretor do estabelecimento, em detrimento do juiz de Execução. Tal escolha pode-se pautar na justificativa de que o diretor, por acompanhar o diaa-dia prisional, teria maior capacidade para avaliar a necessidade ou não de inclusão do preso em disciplina mais rígida.

Sob essa perspectiva, a maneira como o RDD foi regulamentado só reforçou a legitimação do saber penitenciário (construído por seus diretores e funcionários a partir das suas práticas cotidianas) e da discricionariedade do poder exercido pela autoridade administrativa.

\section{B) Resolução SAP 49/02}

A Resolução 49/02 da SAP limitou o número de visitantes por dia de visita dos presos em RDD (artigo $2^{\circ}$ ), e regulamentou a entrevista destes presos com seus advogados. As entrevistas a partir de então deveriam ser previamente agendadas através de requerimento oral ou escrito ao diretor do estabelecimento prisional (art. $5^{\circ}$ da Resolução).

\section{C) Resolução SAP 121/03}

A Resolução 121 da SAP teve por objeto a normatização do Regime Disciplinar Diferenciado no Estado de São Paulo, e revogou as Resoluções que disciplinavam a matéria anteriormente (26/01, 50/01 e 95/01). A Resolução foi editada no dia 22 dezembro de 2003, posteriormente à Lei 10.792/03 de $1^{\circ}$ de dezembro, que instituiu legalmente o RDD.

Logo, as previsões da Resolução no tocante à disciplina, visitas, procedimento de inclusão e exclusão do regime, assim como das causas que recomendem a aplicação no regime diferenciado, são as mesmas da prevista pela lei que o instituiu. 
A especificidade estadual aparece no art. 14 da Resolução, com a menção das unidades prisionais do Estado de São Paulo nas quais seria aplicado o regime mais severo: Penitenciária I de Avaré, Centro de Readaptação Penitenciária de Presidente Bernardes e Centro de Reabilitação Penitenciária de Taubaté (feminino).

\section{D) Lei $10.792 / 03$}

A Lei 10.792/03 reformou a Lei de Execuções Penais. Dentre as muitas mudanças, a lei de 2003 introduziu a previsão legal do Regime Disciplinar Diferenciado em âmbito federal, o que significou sua expansão do Regime a todos os Estados do país, a partir alteração dos artigos $52^{\circ}$, parágrafos $1^{\circ}$ e $2^{\circ}$, art. 53 (inclusão do inc. V), art. 54 art. 60 e art. 84, entre outros.

A inclusão do preso no RDD passou a depender de ordem judicial, a ser requerida pela autoridade administrativa responsável pelo estabelecimento prisional. O $\S 2^{\circ}$ do art. 54 da LEP, ao prever a manifestação do Ministério Público e da defesa no processo decisório, implicitamente assegurava a garantia do contraditório.

Atualmente, o Regime Disciplinar Diferenciado possui as seguintes características: duração máxima de 360 dias, sem prejuízo de repetição da sanção por nova falta grave de mesma espécie, até o limite de um sexto da pena aplicada; recolhimento em cela individual; visitas semanais de duas pessoas, sem contar as crianças, com duração de duas horas; saída da cela por duas horas diárias para banho de sol (nova redação do art. 52 da LEP).

Estão sujeitos ao RDD os presos provisórios ou condenados, nacionais ou estrangeiros, que: pratiquem fato previsto como crime doloso subvertendo a ordem ou disciplina interna; apresentem risco para a ordem e segurança do estabelecimento penal ou da sociedade; que tenham contra si fundadas suspeitas de envolvimento ou participação, a qualquer título, em organizações criminosas, quadrilha ou bando. De acordo com a nova redação da LEP:

“Art. 52 A prática de fato previsto como crime doloso constitui falta grave e, quando ocasione subversão da ordem ou disciplina internas, sujeita o preso provisório, ou condenado, sem prejuízo da sanção penal, ao regime disciplinar diferenciado, com as seguintes características: 
$\S 1^{\circ} \mathrm{O}$ regime disciplinar diferenciado também poderá abrigar presos provisórios ou condenados, nacionais ou estrangeiros, que apresentem alto risco para a ordem e a segurança do estabelecimento penal ou da sociedade.

$\S 2^{\circ}$ Estará igualmente sujeito ao regime disciplinar diferenciado o preso provisório ou o condenado sob o qual recaiam fundadas suspeitas de envolvimento ou participação, a qualquer título, em organizações criminosas, quadrilha ou bando."

Os motivos relacionados nos $\S \S 1^{\circ}$ e $2^{\circ}$ do art. 52 que fundamentam a inclusão no RDD fundam-se no juízo de que o preso apresenta risco para ordem prisional ou social, ou em suspeitas de que participe de organização criminosa. As expressões "alto risco para a ordem e a segurança" e "fundadas suspeitas de envolvimento e participação em organizações criminosas" são vagas e amplas. Tanto uma acusação quanto a outra são auferidas a partir de juízos subjetivos. A primeira por não estar expresso na lei o que representaria o “alto risco”, e a segunda por se basear em mera suspeita, que prescinde de qualquer procedimento investigatório ou acusação formal.

A escolha por um tipo de redação do texto legal (mais aberta ou taxativa, auto-aplicável ou cuja eficácia dependa de outro texto) nunca é aleatória. As palavras e a forma de construção de determinado discurso não são desinteressadas ou alheias à lógica do sistema de poder que o sustenta e que é sustentado por ele.

Mas, além das observações quanto à redação do texto legal, imprescindível vislumbrar a construção da idéia de indivíduo perigoso que permeia não somente o texto da lei, mas o contexto político-criminal dos últimos anos. 


\subsection{O Regime Disciplinar Diferenciado e a criminologia do outro}

David Garland, ao analisar as estratégias punitivas na Grã- Bretanha (Garland, 1999), atesta duas tendências ambivalentes da criminologia contemporânea, que ele denominou a criminologia do eu e a criminologia do outro.

A primeira tendência corresponde às chamadas “novas criminologias da vida cotidiana”, que consideram o crime um aspecto trivial da sociedade moderna, como um prolongamento da interação social. Logo, a ação contra o crime assim percebido teria por objeto mais os hábitos sociais e econômicos da população do que o próprio desviante (Garland,1999, pp.66,74), sendo assim mais preventiva e menos repressiva.

A criminologia do eu concebe o crime enquanto uma realidade banal, um dos riscos assumidos na pós-modernidade, os quais impõem uma nova pauta pra o Direito Penal: objetivar a melhor gestão dos riscos e recursos; reduzir o medo da população e os custos da justiça criminal; dar maior atenção às vítimas. Tais alterações implicam em admitir o “caráter normal das taxas de criminalidade” e a impossibilidade do Estado garantir a ordem e a segurança, reprimindo o crime (Garland, 1999, p.63).

Ulrich Beck (2002) cunhou a expressão sociedade de risco para denominar a sociedade contemporânea, caracterizada por ameaças que dificilmente podem ser captadas ou prevenidas. A noção de sociedade de risco está relacionada à incerteza das decisões que devem ser tomadas sem que se tenha um controle do que poderá ocorrer (Daza, 2001), o que gera nos indivíduos um sentimento de insegurança do qual não se pode escapar.

Como os riscos ${ }^{113}$ da pós-modernidade são imprevisíveis, o sistema de controle para apreendê-los e tentar evitá-los deve ser dinâmico e flexível. Sob pena de se produzir uma defasagem entre dogmática e realidade, o Direito Penal da sociedade de risco não poderia atender à mesma racionalidade persecutória e punitiva da modernidade.

\footnotetext{
113 Para Beck (2002, p.21): “o risco é uma forma sistemática de lidar com os perigos e incertezas produzidos e introduzidos pela própria modernização”.
} 
A nova racionalidade penal contemplaria então a proteção de bens supraindividuais, a diminuição das tradicionais garantias processuais, a antecipação da tutela e a flexibilização de regras de causalidade e de imputação (Machado, 2005, p. 23).

“Seria anacrônico voltar a uma fundamentação absoluta da pena e limitar-se aos bens jurídicos clássicos. Tal medida contrariaria os problemas específicos de legitimação do Estado Moderno e de orientação da sociedade de risco”

$$
\text { (Hassemer, 1999, p.36, tradução da autora }{ }^{114} \text { ) }
$$

Nesse contexto, a estrutura burocrática e a racionalidade garantista representariam um empecilho à efetividade do sistema de controle. Logo, algumas dessas garantias individuais seriam sacrificadas em nome da efetividade da lei penal, principalmente no tocante ao devido processo legal e ao princípio da legalidade.

Ainda que essas medidas extremas e em caráter de urgência não consigam controlar o risco (que continua inapreensível), em certa medida elas funcionam como uma resposta simbólica do sistema de controle. Ao identificar, perseguir e controlar o inimigo, os medos do indivíduo parecem ter sido nomeados, suas incertezas afastadas e as ameaças do mundo, sob controle.

É nesse contexto que se insere a criminologia do outro, que cinde os criminosos dos nãocriminosos, como se aqueles fossem pessoas diferentes das demais: “um pária ameaçador, estrangeiro inquietante, excluído e rancoroso” (Garland, 1999, p. 75). Este é o discurso que irá legitimar um incremento do controle punitivo sobre certas camadas da população.

Para lidar com os paradoxos da existência, tanto a sociedade quanto o indivíduo tendem a criar categorias bipolares (bom/mau, “cidadão-de-bem”/delinqüente, certo/errado) de forma a reduzir e apreender a complexa realidade. Além do que, não se concebe que duas polaridades possam co-existir em uma pessoa ou em um corpo social. Logo além de cindir o bom do mau, projeta-se no ambiente, ou nos outros, o que não é aceito enquanto pertencente a si mesmo.

\footnotetext{
${ }^{114}$ No original da edição espanhola: ““'Sería anacrónico volver a una fundamentación absoluta de la pena y limitar-se a los bienes jurídicos clásicos. Esto sería contrario a los específicos problemas de legitimación del moderno Estado y los problemas de orientación de la moderna sociedad de riesgos"
} 
A prisão possibilita que esses dois eficazes mecanismos de defesa do ego (cisão e projeção) sejam acionados, “a segregação através da prisão representa simbolicamente a expulsão do criminoso que existe dentro do individuo, concentrando naquele que está preso tudo o que existe de ruim” (Sá, 1998, p. 26). E os discursos que sustentam a criminologia do outro só vêm a reforçar tais mecanismos, com a tese de que a maldade e o perigo estão concentrados em indivíduos específicos, cuja mera existência ameaça a coletividade e o Estado Democrático de Direito. Tal discurso legitima medidas extremas por parte do Estado, assim como os mecanismos de segregação desses párias do resto da sociedade.

Os elementos da criminologia do outro, retratada por Garland, podem ser facilmente identificados na teoria do direito penal do inimigo de Günter Jakobs. A teoria proposta pelo dogmático alemão (Jakobs e Meliá, 2003) considera que aquele que não respeita as regras do Estado de Direito e ameaça a sua ordem deve ser considerado inimigo. Legitima-se, no âmbito do Estado, a criação da categoria de não pessoa, não cidadão e a própria crença de que existiriam pessoas essencialmente más, não merecedoras de uma atuação estatal equânime, transparente e democrática.

O inimigo, enquanto não pertencente ao Estado de Direito, deve receber tratamento peculiar do sistema de justiça. Para esses indivíduos, os princípios limitadores e legitimadores do poder punitivo estatal devem ser relativizados ou até suprimidos, podendo ocasionar um adiantamento da punibilidade, solapamento das garantias processuais e desproporcionalidade das penas cominadas. Representando a volta ao chamado direito penal do autor, pelo qual o sujeito é punido pelo o que ele é, e não por seus atos. Nas palavras de Jakobs:

“... O Estado pode agir de dois modos em relação aos delinqüentes: pode ver neles pessoas que delinqüem, que tenham cometido um erro, ou indivíduos que devem ser impedidos, mediante coação, de destruir o ordenamento jurídico [...]Quem não dá segurança cognitiva suficiente de um comportamento pessoal, não só não pode esperar ser tratado como pessoa, como o Estado, de sua parte, não pode dispensar-lhe tal tratamento, sob pena de vulnerabilizar o direito a segurança das demais pessoas. Por isso, seria completamente equivocado demonizar aquilo que é denominado aqui Direito penal do inimigo; a partir 
dele não se pode resolver o problema de como tratar os indivíduos que não permitem sua inclusão em uma constituição cidadã ”

(Jakobs e Meliá, 2003, p.41, tradução da autora ${ }^{115}$ )

No contexto brasileiro, os indivíduos pertencentes às facções criminosas personificariam o inimigo retratado na teoria de Jakobs: aquele que organiza sua vida em torno do crime, não reconhece a existência do Estado de Direito e representa uma grave ameaça à sociedade. Da mesma forma, a legislação de exceção criada para coibir esse tipo de criminalidade (dentre as quais: Leis 9.034/95, 10.217/01 e 10.792/07) pode ser vista sob essa perspectiva.

Mas, como se referiu Marcos César Alvarez ${ }^{116}$, mais importante do que discutir os motivos da escolha de um ou de outro modelo (criminologia do eu e do outro), é refletir sobre os efeitos da aplicação dessas teorias.

A conseqüência da criminologia do outro, mais do que a legitimação da ação do sistema de controle sobre determinados indivíduos ou grupos de indivíduos considerados perigosos (que pode ser considerado como efeito próprio do saber criminológico ${ }^{117}$ ), é a criação de uma categoria de indivíduos cuja mera existência representaria uma ameaça à existência dos demais e ao próprio Estado Democrático de Direito. De tal sorte que a função da pena, atualmente, se resuma ao controle e exclusão desses indivíduos, conforme demonstra Garland:

\footnotetext{
${ }^{115}$ No original da edição espanhola “....el Estado puede proceder de dos modos con los delincuentes: puede ver en ellos personas que delinquen, personas que han cometido un error, o individuos a los que hay que impedir mediante coacción que destruyan el ordenamiento jurídico [...] Quien no presta una seguridad cognitiva suficiente de un comportamiento personal, no solo no puede esperar ser tratado aún como persona, sino que el Estado no debe tratarlo ya como persona, ya que de lo contrario vulneraría el derecho a la seguridad de las demás personas. Por lo tanto, sería completamente erróneo demonizar aquello que aquí se ha denominado Derecho penal de enemigo; con ello no se puede resolver el problema de cómo tratar a los individuos que no permiten su inclusión en una constitución ciudadana”
}

\footnotetext{
${ }^{116}$ Na aula A Criminologia no Brasil, proferida no Curso de Pesquisa Social em Justiça Criminal promovido pelo Instituto Brasileiro de Ciências Criminais (IBCCRIM) no segundo semestre de 2007.

${ }^{117}$ O saber criminológico sempre foi valorizado por sua utilidade política: (“conhecer para controlar”). Talvez por isso a reticência de Foucault com esse saber. Para Foucault (2004, p.138) a criminologia tornou-se indispensável ao funcionamento da criminalidade no século XIX, tendo tal utilidade que não precisa se justificar teoricamente, ter uma coerência ou estrutura. No mesmo sentido Alvarez (2003, p. 33): “A criminologia representou a emergência de um discurso de desigualdade no campo da lei, discurso este capaz de propor a partir da articulação dos campos da lei e da norma um tratamento jurídico diferenciado para determinados setores da população".
} 
"A única resposta prática é colocá-los fora do jogo para proteção do público, o que, no Reino Unido, significa fazê-los sofrer pesadíssimas penas de prisão e, nos Estados Unidos, condenação à morte”

(Garland, 1999, p. 75)

No Brasil, a resposta punitiva aos indivíduos considerados perigosos segue essa mesma direção: o de isolar esses indivíduos, limitando sua capacidade de comunicação e reduzindo drasticamente a possibilidade de que ele interaja socialmente. Neste sentido, o Regime Disciplinar Diferenciado e a chamada "legislação de exceção" são representativos dessa escolha de política criminal e penitenciária.

O discurso da criminologia do outro legitima o aumento da violência e seletividade das instituições do sistema de justiça criminal. Na prisão, a adoção dessas medidas repressivas pode vir a agravar suas conseqüências na conformação identitária e na própria saúde mental do indivíduo ${ }^{118}$, na medida em que é no processo comunicativo, na relação com o outro, na interação social, que a identidade é testada e reafirmada, conforme visto no Capítulo 2 da presente pesquisa.

\footnotetext{
${ }^{118}$ Apesar da pouca publicidade dos dados do sistema penitenciário, muito se tem falado acerca do aumento de casos de doença mental e suicídios no sistema a partir da criação do Regime Disciplinar Diferenciado: "Em onze meses do ano de 2004, o número de casos de suicídios cometidos foi cerca de 500\% maior do que no ano de 2003 inteiro. Enquanto em todo o ano de 2003 foram cometidos 4 suicídios, entre janeiro e novembro de 2004 esse número subiu para 30 ocorrências".

(reportagem da Revista Fórum, www.revistaforum.com.br/vs2/Artigos_Ler.asp?Artigo=\%7B2C6D1EA4-370A4555-AD0D-C3AE77523C31\%7D , acesso 12/12/2007)
} 


\section{CAPÍTULO 6}

\section{ORDEM INFORMAL: AS LEIS DA MASSA E AS FACC̄ÕES CRIMINOSAS}

“... a prisão torna possível, ou melhor, favorece a organização de um meio de delinqüentes, solidários entre si, hierarquizados, prontos para todas as cumplicidades futuras.”

(Foucault, 2002, p. 222)

\subsection{Ordem informal}

“Tudo é administrado pelos detentos, razão pela qual eles têm o poder de dirigir a população carcerária para o rumo que quiserem"

(Jocenir, 2001, p. 20)

"A estrutura e o modo de operação da penitenciária estão formados, basicamente, pelos padrões fornecidos pelos internos"

(Thompson, 2002, p. 80).

Será denominada ordem informal a organização dos presos somada ao conjunto de preceitos normativos elaborados e seguidos pela massa carcerária. A conformação dessa ordem é resultado da interação entre os presos. Sua existência e seu funcionamento não estão previstos na estrutura formal da organização.

Na medida em que nenhuma construção abstrata pode apreender a realidade concreta, todo sistema social será organizado também informalmente. Dependendo do grau de influência da ordem informal sobre a dinâmica organizacional, e da compatibilidade de objetivos das duas instâncias, os indivíduos organizados podem agir no sentido de complementar ou disputar o poder com a Administração prisional. Nesse último caso, a organização informal pode levar a uma redefinição nos padrões da organização formal, inclusive se sobrepondo a ela. 
Como anteriormente mencionado, o exercício total do controle do estabelecimento prisional pelo Estado se aproxima mais de um desejo utópico da sociedade do que de uma possibilidade fática. As limitações e deficiências dessa forma de controle fazem com que o Estado falhe reiteradamente em proteger o preso da intimidação dos outros presos.

Para Sykes (2007, p.36), somente um controle estrito possibilitaria condições de vida toleráveis em um espaço fechado onde estão confinados centenas de homens. Tal controle ocorreria principalmente por meio da disciplina. Esta, enquanto mecanismo de poder regulador da vida e das relações, funcionaria para assegurar a ordem do estabelecimento prisional e a integridade das pessoas que ali habitam, evitando desta forma violências contra a saúde mental e física dos presos.

A disciplina ${ }^{119}$ constitui um tipo de violência, no sentido em que condiciona e fixa o corpo e a mente do indivíduo, limitando sua liberdade de expressão individual. Uma violência sutil e constante, que por sua previsibilidade e relativo sucesso no controle das ameaças da vida na prisão talvez seja preferível aos olhos do preso à violência desmedida e brutal que pode emergir da própria massa carcerária ou das instituições policiais em situações de exceção.

Os presos vivem num profundo nível de ansiedade devido à instabilidade do mundo prisional. As constantes ameaças de outros presos, o risco de sofrer violências (inclusive sexuais) ou de ter seus bens roubados, tornam a vida na prisão impraticável (Sykes, 2007, p.78). Levando-se em conta que o que mais aflige o preso não é a privação de liberdade em si, mas a instabilidade e o grau de tensão do cotidiano carcerário, “o prisioneiro empenhar-se-á em escolher estratégias de sobrevivência” (Castro, 1991).

Entre a falibilidade do Estado e as ameaças da vida no cárcere, resta aos próprios internos criarem mecanismos para sua segurança e proteção. As organizações dos presos se consolidam na dinâmica prisional a despeito dos mecanismos de controle do cárcere. As normas formais da instituição, bem como os mecanismos disciplinares, atuam no sentido de restringir a comunicação dos internos e impedir que eles se agreguem em torno de objetivos comuns.

${ }^{119}$ Cabe lembrar que, tanto a ordem formal quanto a ordem informal lançam mão dos mecanismos disciplinares. 
Dessa forma, a organização formal busca repreender as manifestações de resistência carcerária e desarticular qualquer foco de organização coletiva (Roig, 2005 p.146).

O surgimento e funcionamento dessas organizações na prisão dependem, principalmente, das características específicas do ambiente institucional, tais como histórico da “Casa”, perfil do diretor e dos presos, número de internos e de agentes penitenciários, observação do regulamento formal, arranjo interno de poder, sistema de privilégios, rigidez disciplinar, grau de violência, permissividade e corrupção da instituição etc.

As conjunturas política e social também influenciam na consolidação destas organizações. O tipo de política criminal e penitenciária adotada em âmbito estadual e nacional, assim como as características estruturais e culturais da "sociedade mais ampla”, repercutem inevitavelmente no ambiente social da prisão.

Toda organização informal se reveste de aspectos próprios de um sistema social, contando geralmente com divisão de trabalho interna, código de ética, espaços de troca, postos de prestígio, além de ideologia, mitos, discursos e outras práticas que servirão à coesão interna do grupo (Mills, 1970, p.13).

Donald Clemmer construiu empiricamente, a partir de pesquisa exploratória em uma prisão norte-americana, o conceito de prison primary group. Para Clemmer (1958, p. 115), esses seriam grupos informais formados por uma coletividade de presos, possuidores de um corpo comum de conhecimentos e de interesses suficientes para produzir um entendimento e solidariedade grupal, e caracterizados pelo sentimento de grupo (we-felling) e afeição pessoal (sentimental attachment). E, embora esses grupos se caracterizem também pela unanimidade (unanimity), eles permitem a existência de elementos de competição e resistência internos, desde que estes não comprometam a coesão do grupo. 


\subsection{O indivíduo na organização}

Ao gerenciar os conflitos e as angústias próprios do dia-a-dia prisional, as organizações informais conformaram os padrões de interação social da prisão, e conseqüentemente, a concepção identitária dos indivíduos submetidos àquele sistema social.

Na prisão, as relações são em grande parte permeadas pelo sentimento de desconfiança: a todo tempo, o status do indivíduo está sendo testado. Ele é cobrado (e constantemente vigiado) para que suas ações sejam condizentes com o tipo de preso que ele declara ser ou que esperam que ele seja.

Segundo Silva (1998), o meio social dos presos é determinado mais pelo tipo de relação estabelecida entre seus pares do que pela cultura institucional; ou seja, o impacto da ordem formal sobre a identidade do preso é menor do que o alcance das relações que os presos estabelecem entre si.

Para Sykes (2007), ainda que as privações e frustrações da vida prisional não possam ser eliminadas, suas conseqüências podem ser parcialmente neutralizadas por uma organização informal coesa.

Os laços solidários construídos entre os presos contribuem para a redução do sofrimento da vida na prisão e dos riscos a ela inerentes. Ao compartilhar um sistema de crenças e valores, os indivíduos criam padrões de interação social, a partir dos quais orientarão o seu comportamento. A coesão da organização é reforçada na medida em que cada integrante internaliza os padrões do grupo, e os toma como seus. Quando isso acontece, os membros do grupo passam a vigiar uns aos outros, constituindo uma rede de mecanismos de controle que se estende a todos os espaços da prisão: o "olho da lei” torna-se onipresente.

A quebra de lealdade por um companheiro é disfuncional para o grupo, uma ameaça à sua coesão interna. Uma conduta que destoe dos padrões da organização é tida como uma afronta 
ao poder instituído, e interpretada como traição por seus integrantes. Por isso, as ações que atentam contra as regras e valores do grupo são punidas normalmente com duras sanções.

Geralmente, o grupo reagirá lançando mão de duas formas de punição: condenando o individuo ao ostracismo (obrigando-o a transferir-se do estabelecimento prisional ou a ir para o seguro) ou aplicando-lhe sanções violentas, podendo inclusive levá-lo à morte.

Sykes (2007, p. 107) classifica as repostas que o preso pode dar às exigências do sistema em dois tipos: coesivas (cohesive responses) ou disruptivas (alienative responses). As coesivas corresponderiam às respostas conformistas dos presos, aquelas que sustentam as relações de solidariedade do sistema e a própria ordem prisional. Já as respostas disruptivas compreenderiam as ações que afrontam a ordem pré-estabelecida e produzem relações de adversidade entre os presos.

Para Sykes, as relações prisionais são construídas entre dois extremos: situações de perfeita harmonia entre os internos ou de guerra de todos contra todos. O equilíbrio dessas tendências opostas não é fixo, e a predominância de uma em detrimento da outra varia de acordo com as mudanças estruturais e temporais por que passa o sistema, assim como pelas transformações no arranjo das forças que o governam.

Thompson (2002), a partir da classificação de Sykes, descreve alguns dos papéis sociais desempenhados pelo preso no sistema prisional brasileiro em meados dos anos setenta. Os chamados malucos e os arrochadores estariam entre os presos disruptivos; enquanto o cadeeiro, caguete, políticos, negociantes e bacanas comporiam o grupo de presos que tendem a sustentar o sistema.

Os malucos (psicopatas, débeis mentais e neuróticos) seriam aqueles presos cujo comportamento é caracterizado pelo isolamento e imprevisibilidade. Enquanto a categoria dos arrochadores abrangeria os presos extremamente violentos e egoístas, que usam de todos os meios para a satisfação dos seus desejos, desrespeitando as regras disciplinares e permanecendo insensíveis aos castigos. Para Thompson, um dos motivos que levam a 
população carcerária a aderir ao sistema é justamente garantir a proteção contra os tipos arrochadores (2002, p. 83).

Entre os presos que dão respostas coesivas ao sistema, o cadeeiro talvez seja a figura mais importante. O cadeeiro corresponderia ao que Sykes denominou real man, que além de assumir uma postura conformista dentro do sistema, exerceria grande influência sobre outros presos. Geralmente, é um preso com experiência no sistema prisional, que já se apropriou do modo de funcionamento da prisão, que reconhece as regras institucionais e guarda uma posição respeitosa em relação aos funcionários da penitenciária, assim como aos outros $\operatorname{presos}^{120}$ :

“Sua relação com o guarda não é nem subserviente nem hostil, mais ou menos na base do respeite a minha posição que eu respeito a sua. A liderança que desfrutam não é simplesmente imposta, mas formalmente eleita pela massa. (...) São eles que protegem a comunidade, evidentemente de modo relativo, das agressões dos malucos e arrochadores de um lado, e de outro, da tirania dos guardas”.

(Thompson, 2002, p. 85,86)

O real man de Sykes (ou o cadeeiro de Thompson) se aproximaria da figura do juiz do xadrez descrito por Ramalho (2002). Juiz do xadrez era o preso, depositário das regras do proceder, que tinha o papel de ensinar e servir de exemplo para os demais, além de resolver as querelas que surgiam entre os presos.

Devido ao prestígio obtido entre a massa carcerária, ele contagiaria os outros presos a observarem as regras disciplinares da prisão. Esse tipo de preso exerce um importante papel para o bom funcionamento da instituição, ao sustentar o regime de ordem e segurança,

\footnotetext{
${ }^{120}$ A partir dessa descrição, impossível não se lembrar da personagem Claúdia, do belíssimo documentário $O$ cárcere e a rua, dirigido por Liliana Sulzbach. Claúdia, como a presa mais antiga da penitenciária Madre Pelletier (Porto Alegre), é quem dá as ordens na prisão e proteção àquelas que angariam sua simpatia. Durante toda a sua aparição no filme, ela mantém uma postura calma e firme.
} 
controlando as manifestações violentas entre os presos e destes contra a administração prisional.

O papel desempenhado atualmente pelos líderes das facções criminosas na dinâmica prisional comporta tanto atitudes coesivas quanto disruptivas em relação à ordem prisional. As facções são responsáveis por garantir a manutenção da ordem do cotidiano do cárcere, contribuindo dessa forma com o trabalho da administração prisional e com a coesão dos presos. Porém, quando esse equilíbrio entre o poder informal e formal é rompido, essas organizações utilizam-se do prestígio e da influência sobre a massa carcerária para desafiar a ordem formal, assumindo desata forma uma postura disruptiva em relação ao sistema.

Para Sykes (2007, p.128), o processo de transferência do poder prisional para os presos, ao legitimar a forma ilícita dos internos se auto-governarem, carrega as sementes da sua própria destruição. A repercussão social dos conflitos advindos da disputa de poder entre a ordem formal e informal pode tornar público esse arranjo de poder na prisão. Como é inaceitável para a opinião pública que a administração prisional compartilhe o poder com os presos, o Estado, diante da pressão social, adotará medidas repressivas (eficazes ou meramente simbólicas) para a retomada do poder pela organização formal.

Na visão de Salla (2006), o controle do cotidiano prisional pelos próprios detentos pode implicar em uma série de violências e abusos, entre os quais: constrangimento físico e moral do preso; exigência de contribuições compulsórias; exploração de seus familiares; transferência para outros presos da responsabilidade por infrações na prisão; e controle de toda a arrecadação de dinheiro na prisão (comércio de postos de trabalho e locais de habitação, tráfico de drogas, entrada e uso de celulares).

\subsection{As facções: recorte do objeto}

Antes de apontar quaisquer mudanças na prisão e na própria organização formal a partir da presença das facções criminosas nos presídios, três esclarecimentos são necessários. Primeiro 
é necessário explicitar os critérios utilizados para delinear o objeto; segundo, demarcar o momento em que surgem essas organizações e problematizar as conseqüências e os limites dessa escolha; e, por último, contextualizar esse momento, relacionando-o com as mudanças que ocorriam no âmbito social mais amplo.

Para viabilizar essa breve análise das facções nesta pesquisa, três serão os recortes que delinearão o objeto: quantitativo, espacial e temporal. As referências se limitarão a apenas duas facções criminosas formadas nos Estados do Rio de Janeiro e São Paulo: Comando Vermelho e Primeiro Comando da Capital, respectivamente.

Não se pretende com essa delimitação realizar uma análise minuciosa dessas duas organizações, tampouco desenvolver uma teoria aplicável a todas as organizações criminosas que atuam nas prisões brasileiras. Primeiro porque um recorte aprofundado sobre $o$ funcionamento de uma organização criminosa seria tema para uma pesquisa específica, que tivesse o estudo da facção como seu objeto (o que não é o caso do presente trabalho). E, depois, cada facção tem uma história particular e características próprias, por isso o risco de se falar em "a facção".

Utilizar-se-á a história e o discurso dessas duas organizações criminosas a título exemplificativo, ciente das limitações e dos riscos de realizar uma abordagem reducionista. Com isso, pretende-se apreender, ainda que superficialmente, algumas mudanças ocorridas no cotidiano prisional e na organização dos presos com a consolidação das facções nas prisões.

A afirmação dessas organizações nos Estados de São Paulo e no Rio de Janeiro se deu de formas diversas e em momentos distintos. Pode-se dizer que, no Rio de Janeiro, as facções surgem com a fundação do Comando Vermelho no presídio de Ilha Grande, após o contato com os presos políticos que ali estavam. Em São Paulo, somente tem-se a consolidação desse tipo de organização nos anos noventa, com a fundação do Primeiro Comando da Capital, após o massacre do Carandiru e a publicação da Lei dos Crimes Hediondos, no inicio dos anos 90. 
A fundação do Primeiro Comando da Capital (PCC) em 1993 marca a mudança na forma em que os presos do sistema prisional paulista vinham se organizando. Como esta pesquisa (principalmente no capítulo anterior) se concentrou na análise no sistema prisional e na política penitenciaria paulista, optou-se por estabelecer o início dos anos noventa como marco temporal que divide o sistema prisional em antes e depois das facções.

A escolha desse determinado fato ou data como divisor de águas dentro da realidade prisional é meramente simbólica. As facções não poderiam ter se organizado do dia para noite. Além do mais, não se poderia tratar do surgimento das facções criminosas nas prisões como um fato isolado, desvinculado das características sociais, políticas e econômicas da sociedade e das escolhas político-criminais da época.

As diferenças sublinhadas entre um período e outro não podem ser tidas como conseqüência exclusiva do fortalecimento dessas organizações. É imprescindível que seja levado em conta o lapso temporal entre um período e outro, observando o impacto no âmbito prisional das condições (e da mudança das condições) históricas, políticas e econômicas da sociedade; e ainda, de que forma essas mudanças possibilitaram que as organizações crescessem e se estabilizassem.

O endurecimento da legislação penal a partir dos anos noventa teve grande impacto na realidade do cárcere. Como visto no capítulo anterior, a edição da Lei dos Crimes Hediondos em 1990 fez com que o número de presos e o grau de tensão nos presídios aumentassem. O incremento da pena instituído pela lei, e a vedação de progressão de regime para os condenados por esses crimes, significaram mais presos por mais tempo em regime fechado, e sem perspectiva de sair dessa situação tão cedo.

Essencial à compreensão do ambiente prisional que originou as facções é atentar para o aumento quantitativo (quanto ao número) e qualitativo (quanto à rigidez disciplinar) dos presídios de segurança máxima e regimes de extremo rigor disciplinar, que vem ocorrendo no Estado de São Paulo desde os anos 90. 
Além dessas mudanças no âmbito penal e prisional, as novidades na área da tecnologia da comunicação também afetaram a realidade prisional. A popularização da telefonia celular e sua entrada nos presídios possibilitaram a criação de uma rede de comunicação e controle capaz de transpor os muros. Os presos passaram a se comunicar mais facilmente, com maior liberdade e em “tempo real” ${ }^{121}$, com outros presos que cumpriam pena em estabelecimentos diferentes e com as pessoas de fora da prisão.

O aperfeiçoamento na comunicação possibilitou que as organizações informais se fortalecessem internamente (devido ao aumento da coesão entre seus membros e da centralização das suas decisões) e se espalhassem pelas unidades prisionais. Ao mesmo tempo em que a ampliação dos canais de comunicação dos presos com as pessoas do "mundão" permitiu que essas organizações se expandissem para fora dos espaços institucionais.

Ademais, o uso quase indiscriminado do celular pelos presos permitiu que eles cometessem crimes de dentro dos presídios (extorsão por telefone, tráfico de drogas etc) e comandassem ações criminosas em outros presídios (por exemplo, ordenando a aplicação de sanções aos que violaram as leis do mundo do crime). No depoimento para CPI- Tráfico de Armas, Marcola (suposto líder do PCC) responde ao Deputado Jõao Campos”:

“Deputado - (...) Quais são os diversos mecanismos de comunicação entre os presídios? Marcola - Telefone celular.

Deputado - Só?

Marcola - O senhor quer mais que isso?”

A própria forma de cometer crime mudou no decorrer desses anos: a ação criminosa praticada em grupo passou a ser mais planejada. $\mathrm{O}$ aperfeiçoamento na preparação e na realização de crimes sofisticados e de alta lucratividade só foi possível a partir do respaldo técnico e financeiro assegurado por uma organização. Além disso, o poder econômico das facções, ao

${ }^{121}$ Excetuado o dia da visita, a única forma que o preso tinha para se comunicar diretamente com as pessoas de fora do estabelecimento prisional era por meio de cartas. Há duas limitações neste tipo de comunicação: o lapso temporal que separa a fala dos interlocutores e a censura do conteúdo da mensagem. 
corromper alguns agentes estatais, protege e liberta, ocasionalmente, seus membros das malhas do sistema de justiça.

\subsection{O impacto das facções na ordem prisional}

“Ao contrário de outras organizações de presos existentes naquele momento nas cadeias paulistas, eles (PCC) adquiriram casa vez mais adeptos usando o discurso sindical, de que todos eram iguais, que precisavam se unir, de que um companheiro não seria inimigo do outro e que o inimigo em comum era a administração carcerária. Com esse discurso, aliado à defesa dos presos mais fracos contra a exploração das inúmeras quadrilhas que infestavam o sistema, as lideranças foram ganhando simpatizantes entre os mais fracos, sem poder ou influência dentro do sistema”.

(Mingardi, 2007, p. 60)

A presença das facções criminosas trouxe profundas mudanças à dinâmica prisional. Apesar das organizações informais sempre terem existido nas prisões, o surgimento das facções criminosas nos presídios brasileiros padronizou e centralizou o modo de funcionamento delas.

Além de deter o monopólio sobre a violência, as facções comandam a circulação de bens, legais e ilegais, no universo prisional. Apesar de ser questionável a afirmação de que as facções diminuíram a violência no cárcere (pelo fato de que a violência pode assumir diversas formas, inclusive as mais sutis), elas certamente tornaram o exercício da violência no interior das prisões mais previsível e estável.

Não é raro se ouvir que as condições do preso melhoraram nessa nova realidade. Com a proteção das facções e a rigidez das regras, a integridade física e a liberdade sexual do preso não são mais tão precárias. O código de conduta das facções, entre outras coisas proíbe violência física e sexual, assim como o roubo entre os presos. A punição para quem quebra 
esse código de conduta é exemplar, e atua no sentido de dissuadir os outros de atentarem contra a organização.

Roberto da Silva ${ }^{122}$ narra que, quando ele ingressou na Casa de Detenção de São Paulo, havia disputa para decidir qual cela iria receber o preso recém-chegado, com conveniência dos funcionários e carcereiros responsáveis pela “compra e venda” de presos. Segundo Mingardi (2007, p. 60), quando o PCC assumiu o controle da Casa de Detenção de São Paulo “o número de mortes diminuiu, assim como o número de presos vítimas de qualquer atentado, incluindo sexuais”.

Nesse mesmo sentido é a análise de William da Silva, um dos fundadores do Comando Vermelho:

“A repercussão foi enorme em todo o sistema. Em pouco tempo as regras do antigo Fundão foram sendo adotadas nas cadeias; morte para quem assaltar ou estuprar companheiros; incompatibilidades trazidas da rua devem ser resolvidas na rua; violência apenas para tentar fugir; luta permanente contra a repressão e os abusos. As prisões ficaram mais calmas”.

(Lima, 2001, p.88)

Tanto o Comando Vermelho como o PCC surgem em meio a ambientes carcerários promíscuos e violentos. Como já explicitado no capítulo anterior, o PCC surge no Estado de São Paulo, na prisão de segurança máxima anexa à Casa de Custódia e Tratamento de Taubaté (Piranhão), conhecida por sua rigidez disciplinar e alto grau de violência institucional.

Já o Comando Vermelho surge em 1974 no Instituto Penal Cândido Mendes, em Ilha Grande (RJ). Na época, um “presídio aonde não existia nenhuma lei e nenhum respeito” (Amorim, 2006, p.45), composto por vinte cubículos individuais que abrigavam quatro ou cinco presos em regime de cela dura (Lima, 2001).

\footnotetext{
${ }^{122}$ Em palestra no VI Seminário Internacional do Instituto Brasileiro de Ciências Criminais, realizado em 2001 na cidade de São Paulo.
} 
"O ambiente era paranóico, dominado por desconfianças e medo, não apenas a violência dos guardas, mas também a ação das quadrilhas formadas por presos para roubar, estuprar e matar seus companheiros. Os presos ainda formavam uma massa amorfa, dividida. Matava-se com freqüência, por rivalidades internas, por diferenças trazidas da rua ou por encomenda da própria policia... O maior inimigo da massa da Ilha Grande era, na ocasião, ela mesma, que estava dividida e dominada pelo terror"

(Amorim, 2006, p. 99)

A organização surge em reação às falanges, grupos de presos que até então dominavam os presídio espalhando terror e violência entre os presos. Os presos da galeria B (conhecida como "Fundão") formam então um grupo coeso, que sabia que seria preciso responder com mais violência às violências das falanges.

O saber que respaldou essa nova forma de organização foi apropriado dos chamados presos políticos. Até a anistia em 1979, os condenados pela legislação de exceção da ditadura (Lei de Segurança Nacional- LSN) ficavam concentrados na galeria B do Presídio de Ilha Grande.

A Lei de Segurança Nacional surge para coibir, principalmente, a prática de crimes com o fim de financiar ações terroristas e libertar presos políticos. Porém, os assaltos e seqüestros que não tinham qualquer fim político também foram enquadrados na LSN. Logo, não só os presos políticos foram submetidos à legislação de exceção e julgados pelo Tribunal Militar: a “criminalidade comum” também o foi.

Foi justamente na galeria B do Presídio de Ilha Grande que os presos comuns tiveram contato com presos políticos. A partir de então, os presos passaram a vislumbrar a necessidade de se organizar para se fortalecer perante as violências do sistema. Conforme o teor do bilhete interceptado pela policia em 1981, “Conscientes de que sozinhos e desorganizados não se faz nada nem se ganha dinheiro" (Amorim, 2006, p. 164). 
O Comando Vermelho na Ilha Grande proclamou um “pacto de não violência” entre os presos. Aquele que rompesse com esse pacto, e não aderisse à nova lógica de funcionamento do presídio instituída pela organização, deveria morrer. A punição de um preso simpatizante do CV que assaltou um companheiro era um aviso aos demais:

“O cadáver do preso assaltante, retirado ainda ensangüentado e quente, pelos guardas, ao longo das galerias, anunciou a toda ilha Grande que não estávamos intimidados, nem rendidos, nem brincando. Quem, diante de nos, quisesse manter os velhos hábitos das cadeias - estuprando, assaltando e matando-, que se preparasse para enfrentar as conseqüências”.

(Lima, 2001, p.70)

A consolidação dessas facções no sistema prisional impôs uma nova ordem ao cárcere. O comando da prisão passou a concentrar as decisões e o poder de gestão do cotidiano prisional. Em troca, envolvia os presos em um discurso solidário e os protegia da violência institucional e das ameaças de outros presos.

Com o monopólio do uso da força no sistema, ao mesmo tempo em que as facções garantem a proteção aos seus integrantes, elas mesmas exercem a violência contra aqueles considerados inimigos da organização (normalmente os que violaram suas regras ou os membros de outra facção).

As facções têm hegemonia dentro de um território ${ }^{123}$, dentro do qual exercem controle e dão segurança ao indivíduo. Saindo desse limite, justamente onde a integridade do indivíduo é ameaçada por outras facções, a organização não consegue mais protegê-lo.

Apesar de cada facção ter um código de leis, normas de conduta e padrões que lhe são próprios, elas guardam em comum a construção de um sentimento de grupo entre seus integrantes. As facções ganharam o apoio e a aderência dos presos com o discurso de solidariedade que se materializava tanto na ajuda dada aos membros que estavam presos como

${ }^{123}$ Ainda que no Estado de São Paulo, atribui-se o PCC o comande da grande maioria das prisões do Estado. 
na assistência às suas famílias. O fato dos integrantes de alguns desses grupos chamarem uns aos outros de “irmãos” ilustra como a coesão do grupo foi construída.

Uma das funções do discurso da facção, construído por aqueles que exercem o poder dentro da organização, seria o reforço da coesão interna do grupo. O sentimento de pertencimento ao grupo é construído a partir da comunhão da idéia do sistema de justiça criminal como inimigo comum da massa carcerária, e da lembrança aos presos que seus sofrimentos e queixas são compartilhados por outros indivíduos no sistema prisional.

As falas de um integrante do Primeiro Comando da Capital, e outro do Comando Vermelho, respectivamente, ilustram como a solidariedade aparece no discurso e nas práticas dessas organizações:

“O idealismo é esse da solidariedade, do preso saber que existe muita justiça dentro do sistema penitenciário e que o cara que ta lá, ele precisa de um apoio, ou jurídico ou pra família poder visitá-lo, ou pra ele próprio poder sobreviver lá dentro... para que as pessoas que estão lá, de alguma forma, subsistam de uma forma mais digna do que se não existisse essa ajuda”.

(Marcola, CPI- tráfico de Armas, 2006)

"O nome Comando Vermelho é mais do que um rótulo que a imprensa gosta de usar. Nós somos representantes de um comportamento carcerário diferente: amigo ajuda amigo, para os inimigos o melhor lugar é a geladeira. Eu faço o que for preciso para manter a fé e a união ente nós.... Solidariedade é a palavra mais forte entre nós...”

(Serginho da Ivete, in Amorim, 2006, p. 181,182) 


\subsection{As leis da massa}

“Existe uma regra de convívio em todos os presídios do Brasil, isso é óbvio, independente de PCC, de organização criminosa ou não.”

(Marcola, CPI- Trafico de Armas, 2006)

“Os presos se referiam as tais regras como as leis da massa. São elas que regulam a ordem na vida do crime”.

(Ramalho, 2002, p.51).

As chamadas leis da massa correspondem ao conjunto de regras que regem o mundo do crime. Os indivíduos na prisão instituem regras de convivência, cujo cumprimento é condição para que o preso possa permanecer no convívio prisional.

Apesar da expressão massa carcerária ser utilizada, normalmente, para designar toda a população prisional, ela é usada em outro sentido pelos presos. Ramalho (2002, p.52) percebeu que essa categoria era utilizada pelos presos da Casa de Detenção de São Paulo para designar um trato, uma entidade que não abrangeria o conjunto de todos os apenados, mas somente aqueles que fazem parte da "vida do crime”.

Logo, para ser considerado como pertencente à massa, ou ao mundo do crime, pela ótica dos presos, o indivíduo teria que cumprir ao menos três requisitos: não ter caído na prisão por acidente; perpetuar a ligação com a massa depois que saísse da cadeia; e, por último, continuar na prática de atos criminosos.

O fato de pertencer à massa pressupõe o domínio do saber do mundo prisional. O indivíduo internaliza a cultura prisional e se apropria das regras de como agir e ser respeitado na prisão. Porém, independente de pertencer ou não à massa, uma vez na cadeia qualquer individuo deve obedecer a suas leis. 
“Tem a educação, é o que a massa chama proceder, proceder de malandro.” (Ramalho, 2002, p.56).

Proceder é a qualidade que distingue o preso na massa carcerária. O preso que "tem proceder" é aquele que segue as leis da massa. Caso o preso venha a descumprir alguma dessas regras, ele passa a não "ter proceder”, e logo, não pode continuar a conviver com os outros presos.

Aquele que viola as leis da massa sofre represálias dos próprios presos. A ameaça de sofrer violências físicas faz com que o preso "condenado" pela massa carcerária tenha que se retirar do convívio de uma entre duas formas: transferido para outra unidade prisional ou colocado em uma parte especial da cadeia denominada “seguro" ${ }^{124}$.

Antes das facções terem se consolidado no sistema prisional, a forma de resoluções de conflitos era descentralizada. Os presos resolviam suas próprias querelas: "Na massa cada um era juiz de sua própria causa e a ninguém era atribuído o poder de arbitrar as questões do outro". (Ramalho, 2002, p.51).

Porém, já naquele momento, existia a figura do “juiz do xadrez”, o qual, segundo Souza (1977, p. 30), tinha poderes para proibir ou autorizar condutas, tolerar certos fatos ou denunciar à chefia da disciplina. O juiz do xadrez estaria então autorizado implicitamente pela massa a delatar os companheiros e os entregar à Administração sem que isso fosse considerado delação.

Conforme será visto a seguir, com o surgimento das facções, a figura dos "juízes da massa carcerária” se institucionalizou e ampliou seu alcance. Com a diferença de que agora, ao condenarem o indivíduo, os juízes não o entregam para a organização formal, mas prescrevem as sanções a serem executadas pelos próprios presos.

\footnotetext{
${ }^{124}$ Local da prisão destinado aos presos que não podem ficar na "convivência”, no pátio, pois correm risco de vida
} 
Ao descrever o assassinato de dois presos recém chegados à prisão, os quais estavam dispostos a mostrar liderança a qualquer custo, violentando, inclusive alguns dos companheiros de cela, Percival conclui “Afinal, pela lei do cão, para os presos muito mais implacável que o Código Penal, os dois presos que morreram só tinham mesmo que morrer”. (Souza, 1983, p. 30).

Antes das facções, o preso teria três formas de reagir a uma ameaça: delatar, resistir ou sucumbir. A primeira hipótese, de acordo com os princípios da massa, é inviável: não há pecado pior do que a caguetagem na cadeia. A segunda opção depende da vontade e da força do agredido. Já a escolha pela terceira opção poderia abalar para sempre o status do indivíduo no espaço prisional.

Ramalho (2002, p. 56 a 72) elenca as regras que regiam a Casa de Detenção de São Paulo em meados dos anos setenta:

- não mexer nas coisas de outro preso;

- não conversar enquanto os outros dormem;

- não fumar enquanto o outro faz uma "siesta”;

- pagar as dívidas;

- cobrar as dívidas;

- “adiantar o lado do outro” ${ }^{125}$;

- caso o preso tenha a moral atingida por ofensas ou propostas sexuais, este deve tomar uma atitude compatível com a ofensa recebida, sob pena de se desmoralizar perante os outros;

- não caguetar (regra fundamental)

Talvez pela adversidade da vida da prisão, onde as relações de confiança estão sempre por um fio, o princípio fundamental que rege o mundo prisional, em qualquer tempo e lugar seja o da não delação: "Sempre existiu um pacto entre os presos, chamado vulgarmente como a lei do cão, pois um preso não delata outro preso” (Souza, 1983, p.31).

$\overline{{ }^{125} \text { Ser solidário, ajudar o outro preso. }}$ 
Algumas abordagens precipitadas talvez identifiquem uma natureza selvagem nos homens que habitam as prisões. A mesma impressão errônea, que se tem ao observar superficialmente a sociedade indígena, costuma aparecer num olhar descuidado do universo prisional: de que seus sistemas sociais são pautados pela barbárie e seu comportamento regulados por seus instintos, resultando então em ações brutalmente violentas e marcadamente irracionais.

Malinowski, em sua obra Crime e costume na sociedade selvagem, publicada originalmente em 1926, já alertava:

\footnotetext{
"Um melhor conhecimento dos chamados selvagens teria revelado que os 'desejos animalescos do pagão' eram produto de uma lei firme e de uma tradição rigorosa, exigidas pelas necessidades biológicas, mentais, e sociais da natureza humana mais do que pela emoção desenfreada ou por excessos irrestritos...”.
}

(Malinowski, 2003, p. 9)

As demonstrações de força e resistência dos presos são, sistematicamente, interpretadas como fruto de uma selvageria irracional. Mas o que está por trás das mortes violentas, assim como das rebeliões incitadas, é um código rígido e racional, de forte conteúdo simbólico e regido por uma estratégia muito bem planejada de manutenção das relações de poder.

O primeiro ponto a ser levantado aqui é a formulação de Foucault de que não há contradição ou qualquer incompatibilidade entre o exercício da violência e a razão (in Foucault estuda a razão do Estado, 2006, p. 319).

E depois, a previsibilidade, rigidez e planejamento são características que definem muito melhor a atual ordem social da prisão do que a instintividade. A expansão das facções criminosas pelo sistema prisional brasileiro modificou as formas de violência na relação entre os presos. Essas organizações detêm o monopólio da violência: decidem as querelas dos presos e aplicam punições. As agressões continuam a ocorrer detrás das grades, mas agora 
geralmente ocorrem de forma centralizada, a partir de um comando da facção, e não mais de forma espontânea e eruptiva:

“... a violência é natural do preso, isso é natural. Agora essas organizações vêm no sentido de refrear essa natureza violenta, porque o que ela faz? Ela proíbe ele de tomar certas atitudes que para ele seria natural, só que ele estaria invadindo o espaço do outro, o senhor entendeu? De outro preso. E elas vem no sentido de coibir isso mesmo"

(Marcola , CPI - Tráfico de Armas, 2006)

\subsection{As regras das facções}

A significação dada a um fato é feita por aqueles que exercem o poder de definir as fronteiras do certo e errado. O exercício do poder está no saber que define as regras de conduta e os padrões de normalidade dentro de um sistema social. Com a concentração do poder informal pelos membros das facções criminosas, estas facções passaram a estabelecer as regras de convívio, higiene, disciplina, comportamento no interior das prisões.

As organizações criminosas fazem uso de meios ilegítimos para alcançar tanto os fins culturalmente reconhecidos como válidos como outros, não reconhecidos como válidos. E, ao instituir um código de ética próprio, rejeitam os valores sociais e institucionais:

“Nossa diferença (dos membros do Comando Vermelho em relação aos demais criminosos) é que sabemos distinguir o certo do errado. O certo é o certo, nunca o errado ou o duvidoso. Somos normais como qualquer outra pessoa... O Comando Vermelho é uma filosofia dentro da vida errada”.

(personagem Juliano VP in Barcellos, 2003, p. 345)

Segundo Biondi (2006), a constituição do PCC se deu com a adoção de suas leis, ou seja, a observância de seus preceitos seria fato constitutivo do grupo e não conseqüência da organização. 
O funcionamento de uma ordem estabelecida pela organização informal é atestado por Marcola no depoimento para a CPI do tráfico de armas ${ }^{126}$. Apesar de Marcola negar que sejam “regras do PCC", ele confirma a existência do que ele chamou de "regras de conduta" e de conseqüências para aquele que as descumpre:

“Marcola - Existem regras estabelecidas dentro do sistema penitenciário para que haja uma boa convivência entre os presos.

Deputado - E quem não cumpre essas regras?

Marcola - Quem não cumpre essas regras, de alguma forma, ele vai ser justiçado”.

As leis formuladas pelas facções criminosas foram codificadas e aos poucos se espalharam pelos estabelecimentos prisionais. Segundo Amorim (2006, p. 137), a partir de 1979 as novas e mais radicais palavras de ordem do Comando Vermelho passam a ser ouvidas em todas as cadeias:

- morte para quem assaltar ou estuprar companheiros

- incompatibilidades trazidas da rua devem ser resolvidas na rua, para que a rivalidade entre quadrilhas não perturbe a vida na cadeia;

- violência apenas para tentar fugir

- luta permanente contra repressão e os abusos

O PCC codificou suas leis na forma de um estatuto escrito ${ }^{127}$, o qual se espalhou rapidamente pelas penitenciárias paulistas. A aderência às normas é reforçada na entrada do indivíduo na facção. Na "cerimônia de batismo" do grupo, o ingressante ganha uma cópia do estatuto e se compromete a seguir suas regras:

\footnotetext{
${ }^{126}$ Disponível no endereço http://www1.folha.uol.com.br/folha/cotidiano/20060708-marcos_camacho.pdf , acesso 13/11/2007.

${ }^{127}$ O Estatudo do PCC foi, inclusive, publicado no Diário Oficial do Estado de São Paulo, em 1996, por iniciativa do então deputado estadual Afanázio Jazadji, que então presidida uma CPI.
} 


\section{ESTATUTO DO PCC}

1. Lealdade, respeito, e solidariedade acima de tudo ao Partido

2. A Luta pela liberdade, justiça e paz

3. A união da Luta contra as injustiças e a opressão dentro das prisões

4. A contribuição daqueles que estão em Liberdade com os irmãos dentro da prisão através de advogados, dinheiro, ajuda aos familiares e ação de resgate

5. O respeito e a solidariedade a todos os membros do Partido, para que não haja conflitos internos, porque aquele que causar conflito interno dentro do Partido, tentando dividir a irmandade será excluído e repudiado do Partido.

6. Jamais usar o Partido para resolver conflitos pessoais, contra pessoas de fora. Porque o ideal do Partido está acima de conflitos pessoais. Mas o Partido estará sempre Leal e solidário a todos os seus integrantes para que não venham a sofrer nenhuma desigualdade ou injustiça em conflitos externos.

7. Aquele que estiver em Liberdade, "bem estruturado", mas esquecer de contribuir com os irmãos que estão na cadeia será condenado à morte sem perdão

8. Os integrantes do Partido têm que dar bom exemplo a ser seguido, e por isso o Partido não admite que haja assalto, estupro e extorsão dentro do Sistema.

9. O partido não admite mentiras, traição, inveja, cobiça, calúnia, egoísmo, interesse pessoal, mas sim: a verdade, a fidelidade, a hombridade, a solidariedade e o interesse ao Bem de todos, porque somos um por todos e todos por um.

10. Todo integrante tem que respeitar a ordem e a disciplina do Partido. Cada um vai receber de acordo com aquilo que fez por merecer. A opinião de Todos será ouvida e respeitada, mas a decisão final será dos fundadores do Partido.

11. O Primeiro Comando da Capital PCC, fundado no ano de 1993, numa luta descomunal e incansável contra a opressão e as injustiças do Campo de concentração "anexo" à Casa de Custódia e Tratamento de Taubaté, tem como tema absoluto a "Liberdade, a Justiça e Paz". 12. O partido não admite rivalidades internas, disputa do poder na Liderança do Comando, pois cada integrante do Comando sabe a função que lhe compete de acordo com sua capacidade para exercê-la.

13. Temos que permanecer unidos e organizados para evitarmos que ocorra novamente um massacre semelhante ou pior ao ocorrido na Casa de Detenção em 02 de outubro de 1992, 
onde 111 presos foram covardemente assassinados, massacre este que jamais será esquecido na consciência da sociedade brasileira. Porque nós do Comando vamos mudar a prática carcerária, desumana, cheia de injustiças, opressão, torturas, massacres nas prisões. 14. A prioridade do Comando no montante é pressionar o Governador do Estado a desativar aquele Campo de Concentração "anexo" à Casa de Custódia e Tratamento de Taubaté, de onde surgiu a semente e as raízes do comando, no meio de tantas lutas inglórias e a tantos sofrimentos atrozes.

16. Partindo do Comando Central da Capital do KG do Estado, as diretrizes de ações organizadas simultâneas em todos os estabelecimentos penais do Estado, numa guerra sem trégua, sem fronteira, até a vitória final.

17. O importante de tudo é que ninguém nos deterá nesta luta porque a semente do Comando se espalhou por todos os Sistemas Penitenciários do estado e conseguimos nos estruturar também do lado de fora, com muitos sacrifícios e muitas perdas irreparáveis, mas nos consolidamos a nível estadual e à médio e longo prazo nos consolidaremos a nível nacional. Em coligação com o Comando Vermelho - CV e PCC iremos revolucionar o país dentro das

prisões e nosso braço armado será o Terror "dos Poderosos" opressores e tiranos que usam o Anexo de Taubaté e o Bangu I do Rio de Janeiro como instrumento de vingança da sociedade na fabricação de monstros.

Conhecemos nossa força e a força de nossos inimigos Poderosos, mas estamos preparados, unidos e um povo unido jamais será vencido.

LIBERDADE! JUSTIÇA! E PAZ!

O Quartel General do PCC, Primeiro Comando da Capital, em coligação com Comando Vermelho $C V$

UNIDOS VENCEREMOS

De acordo com Martins (2004, p.41), as organizações criminosas se caracterizam pela capacidade de ver respeitada a sua ordem, e de aplicar sanções àqueles que violam suas regras. Ao instituir um poder paralelo (ou transversal, como preferem alguns) as facções desafiam o sistema de justiça oficial e o próprio Estado de Direito. 
Para impor sua ordem, além de regras próprias, as facções utilizam um sistema de justiça infalível. Essas organizações criminosas fazem uso de um procedimento para julgar os seus integrantes (“sumário”), e aplicam punições àqueles que descumprem suas regras. Além disso, contam com uma rede de comunicação eficaz para disseminar suas ordens e controlar a dinâmica prisional.

\section{A) $\mathrm{O}$ poder da palavra}

A linguagem é um meio importante de exteriorização da cultura. O processo de aprendizado do vocabulário prisional, assim como a perpetuação do seu uso, excluem aqueles que não compartilham dele, e conseqüentemente, daquela cultura (Clemmer, 1958).

“A didática do grupo é infalível. Conversa no pátio, conversa nos corredores, conversa nas celas. A força da palavra em primeiro lugar - mas a força mesmo (armas) sempre disponível”.

(Amorim, 2006, p. 128)

\section{B) Sumário: questão de vida ou morte}

Em depoimento à CPI do Tráfico de Armas de 1996, o delegado Ruy Fontes afirmou ter interceptado uma conversa telefônica na qual 12 lideranças do PCC “julgaram, através de conferência de chamada e votos conferidos, esse sujeito à morte. Ouviram os tiros que mataram esse sujeito” (Souza, 2006, p.45).

Uma vez comprovada alguma injustiça no julgamento da facção, quem puniu e quem autorizou a punição são penalizados. Oposto do que ocorre com o sistema de justiça oficial, no qual os policiais e juízes não têm compromisso com a verdade (Biondi, 2006). 
O funcionamento dos Tribunais do Morro nas favelas do Rio de Janeiro, ainda que realizado fora dos presídios, representa a consolidação, pela facção, de um poder legislativo e judiciário paralelos e contrapostos ao oficial:

“Os tribunais do Comando Vermelho eram, nos anos 90, uma prática comum nas favelas do Rio de Janeiro, mas nunca haviam sido aplicados na Santa Marta. Os tribunais ajudaram a consolidar, pelo medo, o poder do trio na gerência do morro (...). As sentenças se tornaram mais imprevisíveis e cruéis. Mesmo os que eram absolvidos dificilmente escapavam do espancamento em lugares públicos”.

(Barcellos, 2003, p.210)

\section{C) Penas cruéis: execução da sentença}

“O ponto extremo da justiça penal no Antigo Regime era o retalhamento infinito do corpo do regicida: manifestação do poder mais forte sobre o corpo do criminoso, cuja destruição faz brilhar o crime em sua verdade”.

(Foucault, 2002, p.187)

As penas impostas pelas facções aos seus membros nos remetem à forma de punição do Antigo Regime. Os suplícios vigoraram enquanto principal meio de punição até a consagração do princípio da humanização das penas, construído a partir da ideologia iluminista e da nova racionalidade penal do fim do séc. XVIII, representadas, principalmente, na obra de Cesare Beccaria, “Dos delitos e das penas”, publicada em 1974.

A exemplaridade desse tipo de pena é garantida pela sua execução pública, em forma de espetáculo, e com uso de meios cruéis. Tais elementos estão presentes na descrição da “cerimônia do estripamento” feita por Souza (2006, p. 17,18): 
“- Ele merece uma chance?

Uma longa vaia marcou a posição dos convidados, que começaram a se aproximar mais, escolhendo uma boa posição para contemplar as cenas seguintes (...). A um gesto que o anfitrião fez com a mão direita foi chegando, a passos curtos, compondo numa coreografia aparentemente ensaiada, um homem vestido de avental branco impecavelmente engomado, brandindo nas mãos um punhal reluzente. O homem do pedido negado, que já se sabia ser um condenado, foi colocado de joelhos, enquanto quatro troncos de madeira eram arrastados. (...) O anfitrião fez sinal de negativo, com o polegar direito, (...) o que bastou para o homem de avental dar um corte, em diagonal, mas sem profundidade, no peito do condenado (...) A platéia aplaudiu quando o sangue correu. A punhalada seguinte foi mais forte, na altura do ombro, e a arma foi girando, penetrante, nem vaivém circulante - que provoca dores terríveis - o condenado berrava e gemia..." 


\section{CAPÍTULO 7}

\section{O PRESO E AS FACCÕES CRIMINOSAS}

"A humanidade não progride lentamente, de combate em combate, até uma reciprocidade universal, em que as regras substituiriam para sempre a guerra; ela instala cada uma de suas violências em um sistema de regras, e prossegue assim, de dominação em dominação. (...) O grande jogo da história será de quem se apoderar das regras, de quem tomar o lugar daqueles que as utilizam, de quem se disfarçar para pervertê-las, utilizá-las ao inverso e voltá-las contra àqueles que as tinham imposto...”.

(Foucault, 2004, p.25)

\subsection{Resistência: um ponto fundamental para a análise do poder}

A atitude desses grupos, enquanto resistência ao poder exercido pelo Estado, não está alheia a ele. As formas de resistência são constituídas em meio a relações de poderes, e produzidas pela ação do sistema de controle. Por isso, os atos de resistência são um prisma privilegiado para a compreensão do próprio poder:

“... usar formas de resistência contra as diferentes formas de poder como um ponto de partida (...). Mais do que analisar o poder do ponto de vista de sua racionalidade interna, ela consiste em analisar o poder através do antagonismo das estratégias. Por exemplo, para descobrir o que significa, na nossa sociedade, a sanidade, talvez devêssemos investigar o que ocorre no campo da insanidade; e o que se compreende por legalidade, no campo da ilegalidade. E, para compreender as relações de poder, talvez devêssemos investigar as formas de resistências e as tentativas de dissociar estas relações”

(Foucault, 1995, p.234). 
A resistência ao poder não existe fora dele. Não há nenhum “exterior absoluto” em relação ao poder, tampouco um campo que esteja imune a sua ação. Os mecanismos de resistência configuram uma das formas do indivíduo reagir à ação dos mecanismos de controle, sem que isso signifique desvincular-se deles.

O poder, mais do que um atributo de um indivíduo ou uma instituição, é um fluxo de forças que permeia todas as relações sociais. Assim como o poder, a resistência não está concentrada. Ela assume formas múltiplas e pulveriza-se no meio social:

“Portanto, não existe, com respeito ao poder, um lugar da grande Recusa alma da revolta, palco de todas as rebeliões, lei pura do revolucionário. Mas sim resistências, no plural...”.

(Foucault, 2005, p. 91).

A resistência também não é pura, imune ao poder. Os mecanismos de resistência criados para neutralizar a ação de um poder constituem, em outra forma de seu exercício, um contra-poder. Todos, em algum momento, resistem e exercem o poder, da mesma forma que, inevitavelmente, submetem outros e são submetidos pela ação do poder.

As facções criminosas, ao estabelecerem uma relação de hostilidade com o poder estabelecido, podem ser tidas como um tipo de resistência. A inserção na organização informal constitui um tipo de ajustamento do indivíduo ao sistema prisional, uma forma de ele responder às exigências institucionais.

Pela fala de um dos fundadores do Comando Vermelho, pode-se depreender de que modo a ação do poder contribuiu para que os indivíduos se organizassem em torno da organização. O agrupamento dos indivíduos seria uma forma que os presos encontraram para viver na adversidade, um caminho para não sucumbir à violência do cárcere: 
"O que eles chamavam de Comando Vermelho não poderia ser destruído facilmente: não era uma organização, mas, antes de tudo, um comportamento, uma forma de sobreviver na adversidade. O que nos mantinha vivos e unidos, não era uma hierarquia, nem uma estrutura materiais, mas sim a afetividade, que desenvolvemos uns com os outros nos períodos mais duros de nossas vidas. Como fazer nossos carcereiros (ou mesmo a sociedade) acreditarem nisso?”

(Lima, 2001, p.63)

Porém, como será aprofundado adiante, o ingresso do indivíduo na facção não o liberta da ação do poder. Primeiro porque as facções não estão sempre em relação de oposição com o poder institucional, e muitas vezes seus objetivos e suas ações são complementares aos da organização formal da prisão. E depois, porque a facção exerce outro tipo de poder sobre o indivíduo preso, a partir da consolidação de suas práticas na dinâmica prisional e da elaboração de um discurso próprio que as sustente.

\subsection{Funcionamento das facções criminosas}

"Com estatuto. Com batismo. Com ritual de entrada. Com pagamento de mensalidade. Com garantias de apoio para que estivesse fora ou dentro dos cárceres. Com investimentos. Com compra de pessoas que atuam profissionalmente em vários níveis, inclusive jurídico (...). Criou-se aos poucos uma irmandade, um estilo mafioso, na qual todos passaram a ser tratados $e$ compromissados como irmãos”.

(Souza, 2006, p. 21)

Há algum tempo, vem se discutindo a conceituação jurídica e sociológica de crime organizado (Zaffaroni, 1996; Mingardi,1998; Gomes e Cervini, 1997), e se as facções criminosas se encaixariam ou não nessa categoria. 
Algumas das características do crime organizado o tornam diferente do crime comum. Segundo Mingardi (2007, p. 56), são elas: organização hierárquica, previsão de lucros, divisão do trabalho, planejamento empresarial e simbiose com o Estado.

O crime organizado atua e disciplina as áreas do mercado não regulamentadas pela ordem estatal-legal. A categorização de crime organizado teria a finalidade econômica de neutralizar a competitividade desses grupos. (Zaffaroni, 1996, p. 53).

Para Michel Misse ${ }^{128}$, a criminalização privilegia certos mercados informais e alguns agentes desses mercados. Cruzando as variáveis: mercadoria lícita, mercadoria ilícita, mercado formal e mercado informal; poder-se-ia chegar a quatro formas de mercados ilegais: mercadoria ilícita vendida no mercado formal e informal, mercadoria lícita vendida no mercado informal, e até mesmo a mercadoria lícita vendida no mercado formal. Porém, a denominação mercado ilegal se restringe às mercadorias ilícitas vendidas no mercado informal.

A persecução ao crime organizado normalmente se restringe às ações ilícitas praticadas por organizações ilícitas, deixando de fora as atividades ilícitas praticadas por organizações lícitas. Raramente as organizações lícitas e seus representantes são alvo do sistema de controle. Ainda que estas organizações também ocupem o setor ilícito do mercado, e que dificilmente deixem de lançar mão de alguma prática ilegal na realização de suas atividades lícitas, suas atitudes não são tidas como criminosas.

A seletividade do sistema de controle evidencia-se pelo fato de que, apesar do conceito de crime organizado abranger uma série de atividades e agentes, o sistema de justiça concentra sua persecução às atividades e membros das facções criminosas.

As atividades do crime organizado envolvem diversos atores sociais, inclusive agentes estatais e pessoas do alto grau de hierarquia social, que não são selecionados pelo sistema de controle. Ademais, o crime organizado no Brasil abrange, além do tráfico de armas e de

\footnotetext{
${ }^{128}$ Sessão 1 do Seminário Internacional Crime Organizado e Democracia, realizado pelo Núcleo de Estudos da Violência (NEV) e a Pró-Reitoria de Cultura e Extensão da Universidade de São Paulo (USP), São Paulo, 2007.
} 
drogas, uma série de outras atividades tais como o comércio ilegal de pedras preciosas, borracha, couro, madeira etc.

Mais importante do que discutir se as facções criminosas se enquadram ou não da categoria crime organizado é analisar qual é a funcionalidade política da criação desse tipo de criminalidade especifico, e quais as conseqüências dessa categorização e da legitimação do discurso que a sustenta.

Toda escolha do sistema de justiça criminal guarda uma utilidade política. O mesmo discurso que sustenta a existência de um tipo diferente de criminalidade, legitima medidas repressivas para o seu combate.

A representação social destes grupos enquanto inimigos da sociedade, que ameaçam a ordem social, autoriza o Estado a tomar medidas repressivas no combate a esse tipo de criminalidade. O Estado, em nome da eficiência do sistema de controle, passa a instituir medidas e regimes de exceção, e a suprimir garantias constitucionais.

Sá (2007), a partir da obra de Freud “Psicologia das massas e análise do ego”, propõe uma leitura alternativa ao modelo de crime organizado para o funcionamento das facções criminosas.

Por esta interpretação, o comportamento do indivíduo no âmbito das facções criminosas se aproximaria da psicologia das massas. Em situação de grupo, as pessoas agem de forma diferente do que fariam se estivessem sozinhas: o sentimento de onipotência toma conta do indivíduo, seus medos e a noção de impossibilidade desaparecem para ele.

Ao mesmo tempo, a massa ao representar um poder ilimitado perante o individuo, faz com que ele aja em conformidade com seus preceitos e obedeçam à sua autoridade. É perigoso o indivíduo enfrentá-la sozinho. Para garantir sua própria segurança ele deverá agir conforme os outros indivíduos, e se preciso, chegar a "uivar com os lobos” (Freud, 1943, p. 30). 
O único elemento que se diferencia na massa é o seu líder, chamado por Freud de caudilho. Os indivíduos mantêm uma relação hipnótica com o caudilho: eles idealizam a sua figura e, cegamente, cumprem suas ordens. A massa se satisfaz com as realizações e conquistas de seu líder, independente se ela terá algum ganho direto com isso.

Nesse sentido, enquanto a identidade dos indivíduos que compõem a massa é enfraquecida, a do caudilho é exaltada e enaltecida. Somente o caudilho tem um ego diferenciado da massa, e ele utilizará de sua influência para sugestionar os liderados em beneficio de seu crescimento individual.

A partir da obra The Group Mind de Mac Dougall (1920), Freud discute quais as condições para que as pessoas acidentalmente reunidas em venham a compor um grupo (ou uma massa no sentido psicológico do termo). Entre elas, estariam: compartilhar os mesmos sentimentos perante uma situação, ter interesses em comum, influencia mútua de uns sobre os outros. Quanto maior for a homogeneidade entre o grupo de indivíduos, mais facilmente eles formaram uma “massa psicológica”, e manifestarão uma “alma coletiva” (Freud, 943, p. 29).

Segundo Dougall (apud Freud, 1943, p. 32), para que sejam afastadas as desvantagens psicológicas da formação de um grupo, é necessário que cinco condições sejam satisfeitas: grau de continuidade material ou formal de existência do grupo (persistência dos mesmos indivíduos ou das mesmas funções, respectivamente); relação emocional do indivíduo com o grupo todo, de modo que cada membro do grupo tenha "alguma idéia definida da natureza, composição, funções e capacidades do grupo"; o grupo deve interagir ("talvez sobre a forma de rivalidade") com outros grupos semelhantes, mas que dele difiram em muitos aspectos; o grupo deve envolver seus membros em torno de hábitos, tradições e costumes; e ainda, que "o grupo tenha uma estrutura definida, expressa na especialização e diferenciação de funções de seus constituintes”.

As faç̧ões parecem cumprir com as cinco condições. Primeiro porque a estrutura formal da organização é definida e suas funções divididas e diferenciadas. Ela permanece a mesma a despeito da grande volatilidade de seus líderes e da intensa disputa interna de poder (que 
ocasionam inúmeras mortes e uma constante mudança no quadro dos homens que compõem o grupo).

Segundo, porque a relação emocional do indivíduo com as facções é garantida por, ao menos, três fatores: por seus indivíduos compartilharem a condição de preso e os sentimentos dela advindos; por vivenciar, ainda que simbolicamente, o poder político-econômico do grupo; pelo discurso de solidariedade entre os seus membros.

Depois, todas as facções, ao guardar um padrão cultural próprio (valores, rituais, tradições, códigos de ética, etc.), reforçam o sentimento de pertencimento ao grupo e, conseqüentemente, sua unidade.

E, ao final, é inegável a interação das facções com outras facções. Elas estabelecem entre si tanto relações de rivalidade, principalmente na disputa da hegemonia de poder sobre um território (sobre uma zona da cidade ou uma prisão); quanto de apoio mútuo, como o caso da aliança entre o Comando Vermelho do (RJ) e o Primeiro Comando da Capital (SP), que consta em ambos os estatutos destas facções.

\subsection{Hierarquia interna e papéis sociais}

“As lideranças estavam sustentadas em uma organização mantida por um quadro hierarquizado de 'funcionários', disciplinados e obedientes, capazes de executar ordens sem questioná-las”.

(Adorno e Salla, 2007, p. 9)

Uma das características de qualquer organização é a distribuição de funções. O papel que o indivíduo assume no grupo influencia na constituição de sua identidade, dentro da organização e fora dela. 
Para ilustrar como pode ser construída a hierarquia, e os tipos de papéis que podem ser desempenhados por um indivíduo dentro dessas organizações criminosas, tomar-se-á como base o sistema de organização do Primeiro Comando da Capital.

A primeira divisão que se estabelece é entre as pessoas de dentro da facção e as de fora dela. Segundo Biondi (2006, p. 33), a categoria nós, quando usada pelos membros do PCC, inclui os irmãos (membros do grupo) e primos (convivem com os irmãos, compartilham das suas regras). Já os outros designaria tanto as pessoas de fora do mundo do crime ou da instituição prisional (chamados também de zé povinho), como os coisa, presos excluídos do convívio pela facção.

O PCC conta com estruturação vertical e com um comando centralizado. Porém, sua estrutura não é mais piramidal, a facção agora está organizada em células. A vantagem do sistema celular é que as células não se comunicam entre si, de modo que, se uma célula "cair" nas mãos do sistema de controle, não leva as outras juntas. Conforme descreve o Ministério Público de São Paulo, em denúncia apresentada à $3^{\text {a }}$ Vara Criminal da Capital:

\begin{abstract}
“Em decorrência das sucessivas investigações policiais e ações penais desfechadas, apurou-se que o Primeiro Comando da Capital estabeleceu uma nova estrutura para a sua atuação criminosa, desmobilizando parcialmente o molde piramidal já descrito. Fora ele descentralizado em anéis ou células, cada qual com discricionariedade dentro de sua área ou ramo de atividade”.
\end{abstract}

(In Souza, 2006, p. 105).

Pela análise de Biondi (2006, p. 34), a hierarquia dentro do grupo é estabelecida a partir de dois critérios: o tipo de estabelecimento prisional em que o indivíduo cumpre pena e sua função na organização.

O primeiro critério é definido primeiro pela rigidez da unidade prisional, e depois pelo fato de ser um estabelecimento para presos provisórios ou com condenação definitiva. Pela ordem decrescente de importância, estariam: Regime Disciplinar Diferenciado, Penitenciária, Centro 
de Detenção Provisória/Cadeias Públicas, Distritos Policiais. Por exemplo, o piloto que cumpre pena em uma penitenciária está acima na hierarquia de outro piloto que está em um CDP.

Já as funções que os indivíduos exercem na organização podem ser divididas, basicamente, em três: liderança geral, pilotos e soldados. No topo da hierarquia está a liderança geral: um ou dois presos que comandam a organização, chamados também de fundadores ${ }^{129}$. Os pilotos (ou faxinas) são detentos responsáveis por um presídio ou por uma ala, passam a ordem vinda das outras lideranças para que os soldados executem. Na base da hierarquia estão os soldados: presos ou homens de fora da prisão, que devem executar as ordens recebidas.

Segundo ainda a denúncia do Ministério Público transcrita por Souza (2006, p. 106), além dessas, outras funções foram instituídas pela facção. A organização se aperfeiçoou com a criação de três outras figuras: os torres, os sintonias e os disciplinas. Os torres são as lideranças decisórias, uma “espécie de última instância antes da liderança geral”; os sintonias, os integrantes responsáveis por estabelecer contato entre as células; e os disciplinas são os que cobram dos demais o cumprimento das tarefa que lhes foram ordenadas, configurando uma função de controle interno ou “corregedoria no âmbito da organização”.

À grande maioria da massa carcerária resta servir à facção enquanto soldado. O indivíduo que ocupa o grau mais baixo na hierarquia da facção é justamente aquele que terá de se expor perante o sistema de controle, já que caberá a ele executar os acertos de contas na prisão, participar na linha de frente dos atentados, assumir o crime de outros etc.

De certa forma, o soldado é expropriado do modo de funcionamento da facção; ele não tem poder de voz tampouco pode influenciar as decisões do comando. É-lhe reservado só o ato, não o pensamento.

\footnotetext{
${ }^{129}$ A utilização hoje do termo fundador para denominar a liderança geral do grupo talvez não tenha mais tanto sentido. A grande maioria dos fundadores do PCC já está morta, e Marcola, a quem é atribuída atualmente a liderança do PCC, não foi um de seus fundadores, apesar de estar cumprindo pena na época da fundação no anexo de Taubaté.
} 
Segundo Sá ${ }^{130}$, os presos que representaram o papel de "soldados” na hierarquia das facções são recrutados no fundo da cadeia, entre aqueles que não recebem visitas, que têm benefícios vencidos, que não tem assistência jurídica.

Os presos que não recebem visitas e não têm recursos para pleitear seus direitos estão mais vulneráveis ao processo de prisionização do que outros. O sentimento de exclusão (característico do indivíduo encarcerado) é acentuado pela falta de contato com as pessoas do “mundão”, e pela impotência do indivíduo perante o sistema de justiça.

Nesse contexto, as facções surgem como meio de inclusão do indivíduo. O sentimento de despertencimento social, comum aos seus membros, é substituído pela experiência de pertencimento a um grupo. A idéia de pertencer a um grupo social, permeado por redes de solidariedade, traz conforto e segurança ao indivíduo. Se a aderência aos valores e regramentos da sociedade dificilmente traria vantagens para o indivíduo, a coesão da organização lhe traz proteção e lhe devolve a sensação de empoderamento.

“O grupo impressiona o indivíduo como um poder ilimitado e um perigo insuperável. Momentaneamente, ele substitui toda a sociedade humana, que é a detentora da autoridade, cujos castigos o indivíduo teme e em cujo benefício se submeteu a tantas inibições”.

(Freud, 1943, p. 30, tradução da autora ${ }^{131}$ )

O sentimento de pertencimento é construído a partir do discurso de fraternidade das facções, e reforçado por algumas práticas do grupo. Contudo, por trás do discurso da irmandade, a facção reproduz a seletividade do sistema de justiça criminal. Os presos da base da hierarquia da facção são selecionados para executarem as ordens da facção, enquanto os mandantes permanecem resguardados, não se expõem ao sistema de controle.

\footnotetext{
${ }^{130}$ Na mesa As Faç̧ões Criminosas e seus Desafios para a Execução Penal do $12^{\circ}$ Seminário Internacional do IBCCRIM, realizado em 2006, na cidade de São Paulo.

${ }^{131}$ No orginal da edição argentina: "La masa da al individuo la impresión de un poder ilimitado y de un peligro invencible. Substituye, por el momento, a la entera sociedad humana, encarnación de la autoridad, cuyos castigos se han temido y por la que nos imponemos tantas restricciones".
} 
Se fora da prisão os mais vulneráveis estão sujeitos ao sistema de justiça criminal, dentro da prisão também serão pegos pela Administração Prisional, e sofrerão sanções pelos seus atos, ou por atos que sequer cometeram. Conforme já visto, identifica-se como a figura do criminoso o sujeito que violou as regras da lei penal, quando, na prática, são assim denominados aqueles que foram selecionados pelo sistema de justiça. O mesmo ocorre dentro da prisão. O universo daqueles que violam as regras não corresponde ao dos indivíduos que são descobertos e punidos.

Já o piloto é aquele que detém poder de mando em um determinado presídio ou pavilhão. O piloto corresponderia à figura do faxina, que existe há algum tempo nas prisões brasileiras. O faxina é o preso de confiança do diretor da unidade, normalmente responsável pela limpeza (daí essa denominação), entrega de cartas, distribuição de elementos e outras atividades mantenedoras do funcionamento da unidade. Os presos que trabalham junto à Administração do presídio também ocupam uma posição privilegiada, pela mobilidade que o cargo permite, assim como pela proximidade dos funcionários e da burocracia da instituição (acesso a computadores, prontuários etc.).

“... atividades administrativas das unidades prisionais - que deveriam ser atribuição de agentes penitenciários concursados - são realizadas por ‘faxinas' (...). São esses faxinas os olhos e braços de ferro da direção das unidades. Sem a atuação deles a Direção não teria informação, identificação de vulnerabilidade e estabilidade efetiva".

(Caldeira, 2005, p. 12)

A representação desse papel proporciona ao faxina uma grande vantagem: a liberdade de circulação pelo presídio, que lhe garante acesso à massa carcerária e a possibilidade de usar essa mobilidade para fins não lícitos. Por isso, a função do faxina sempre foi exercida por uma liderança reconhecida pela massa carcerária, "geralmente os caras que trabalha na faxina são considerados bandidões” (Ramalho, 2002, P.58). 
A existência de um preso de confiança do diretor que ajudasse no controle dos demais antecede as facções criminosas. A pesquisa de Ramalho (2002), realizada na Casa de Detenção de São Paulo em meados dos anos setenta, já mostrava a existência dos faxinas.

A diferença é que, com as facções criminosas, os faxinas não têm autonomia sobre o presídio, mas estão subordinados àqueles que estão hierarquicamente acima deles na organização.

Conforme o relato de José de Jesus ${ }^{132}$, advogado da Pastoral Carcerária, quem recebe a Pastoral na cadeia são os faxinas, e "quando a administração quer alguma coisa dos presos, não comunica à massa, aos demais. E o faxina, geralmente, é o cara indicado pela facção. $O$ faxina seria uma liderança de terceiro escalão, o último da hierarquia”.

A função de liderança, exercida pelos pilotos e, de forma mais acentuada, pela chefia geral da organização, por ser a mais diferenciada da organização e fundamental ao seu funcionamento, será analisada em separado, no próximo item.

\section{4. Líder na organização}

"Não existe um ditador. Embora a imprensa fale, romanticamente, que existe um cara, o líder do crime. Existem pessoas esclarecidas dentro da prisão, que com isso angariam a confiança de outros presos. Por que? O preso vem com problema, você dá uma solução pra ele, mostra uma lógica, mostra a forma como ele está sendo tratado ou qual a forma que ele deveria ser. O senhor me entende?”

(Marcola em depoimento a CPI do Tráfico de Armas, 2006)

${ }^{132}$ Edição Extra da revista Caros Amigos: PCC, 2006, p. 22 
"Não nos esqueçamos, contudo, que a exigência de igualdade em um grupo, aplica-se apenas aos membros e não ao líder"

(Freud, 1943, p. 76, tradução livre ${ }^{133}$ )

Lideranças sempre existiram nos presídios, assim como em qualquer organização social. Líder é a pessoa com capacidade de influenciar as ações e concepções dos quais lidera, dirigindo seus comportamentos para determinado fim.

Para justificar a legitimidade das lideranças prisionais, William da Silva (um dos fundadores do Comando Vermelho) se apropria do saber sociológico:

"Ao contrário do que saia publicado, as lideranças nascidas da luta eram um fator de equilíbrio. Todos os grupos sociais têm seus líderes, inclusive as minorias segregadas. Por que isso não pode ocorrer com os presidiários? Porque considerar que a formação de grupo é sempre negativa? O homem não é um ser social?”.

(Lima, 2001, p.107)

A existência de liderança dentro de grupos informais é um fator de controle social. Para Clemmer (1958, p. 149), controle social é o complexo de forças que age na interação das pessoas, e que têm como função mantê-las na linha e garantir a continuidade do modo que as coisas são feitas. A natureza da liderança depende da cultura em que ela opera. Quanto mais heterogêneos forem os indivíduos que compõem o grupo social, maior deverá ser o controle sobre eles.

Segundo Clemmer (1958, p. 138), são características do líder prisional, entre outras: retidão, coragem, generosidade, modéstia, educação, vocabulário extenso, cuidado pessoal, habilidade no trato com os oficiais, possuir dinheiro e um grande conhecimento de determinada técnica

\footnotetext{
${ }^{133}$ No original da edição argentina "Ahora bien, no habremos de olvidar que la reivindicación de igualdad formulada por la masa se refiere tan solo a individuos que la constituyen, no al jefe".
} 
de crime, ter atitudes contra o Judiciário e a Administração prisional, ter participado de um crime, fuga ou rebelião espetacular.

Com as facções, o poder informal foi centralizado na figura das lideranças, e pôde desta forma ser identificado e localizado. Apesar disso, os supostos líderes dessas facções criminosas, não raramente, negam o exercício desse papel e a própria existência da facção criminosa:

“Não sou líder de coisa nenhuma. Esta organização não existe. E invenção da policia e da imprensa”.

(Lima, 2001, p.102).

O próprio Marcola (suposto líder do PCC), durante todo depoimento à CPI do tráfico de armas, negou ser líder do PCC e declarou sistematicamente: "Não há provas de que pertenço ao PCC. Os que o afirmam são a imprensa e até mesmo os presos. Não sou chefe de absolutamente nada. Luto por meus direitos. Se a maioria dos detentos se reconhece em minha luta, não posso fazer nada” ${ }^{134}$.

Sá ${ }^{135}$ relata que, em uma conversa que teve com uma das lideranças do sistema prisional, esta negava ser um líder, se dizia ícone da população carcerária. Para Sá, o termo ícone estaria ligado ao fato desses presos serem a representação das grandes aspirações da massa carcerária.

A palavra ícone é utilizada para designar um símbolo ou uma representação, e guarda forte conotação religiosa. Ícone era “na igreja ortodoxa russa, representação em superfície plana, de Cristo, da Virgem, de certos santos” ${ }^{136}$.

As ligações simbólicas com o sagrado, e o ritualismo de suas ações, são elementos que contribuíram para a coesão interna desses grupos. Em relato à reportagem da Revista Caros

\footnotetext{
134 “Uma radiografia do PCC” in Le monde diplomatique -Brasil, dezembro de 2006 http://diplo.uol.com.br/2006-12,a1461, acesso 5/01/2008.

${ }^{135}$ Na mesa As Facções Criminosas e seus Desafios para a Execução Penal do $12^{\circ}$ Seminário Internacional do IBCCRIM, realizado em 2006, na cidade de São Paulo.

136 Dicionário etimológico da língua portuguesa (Cunha, 2007).
} 
Amigos $^{137}$, o padre Valdir (Pastoral Carcerária) descreve o culto realizado em algumas “prisões do PCC”:

“Eles formam um círculo e cantam um hino. Depois, um orador relembra os mártires da facção e enumera os lugares comandados pelo partido. Em seguida baseado em um profeta do Antigo Testamento, ele faz um 'sermão' ligando o personagem bíblico a uma liderança da facção. E finaliza o ritual com o pai nosso ecumênico”.

O próprio padre Valdir ${ }^{138}$ narrou o desabafo de um delegado de polícia que não agüentava mais escutar todo dia, pontualmente às 9:00 horas, o hino do PCC. Esse tipo de manifestação litúrgica também pode ser observado em uma cena do excelente documentário Justiça, dirigido por Maria Augusta Ramos, na qual a câmera registra o momento em que os presos da carceragem da Polinter entoam uma espécie de cântico religioso do Comando Vermelho.

Os líderes alcançam o prestígio e exercem seu poder dentro da prisão. O poder aquisitivo lhes permite, às vezes, sair da prisão ou evitar entrar nela, pela compra de fugas e acertos. Além do mais, usam seu poder de influência sobre a massa carcerária, enquanto força política de oposição à ação repressiva do Estado.

No estudo de Fisher (1989) sobre organizações penitenciárias, consta que o poder dos dirigentes reside na capacidade de encobrir e ocultar processos contraditórios. O líder incentiva a massa a questionar o sistema de justiça, enquanto cuida pra que ela não se atente para as contradições sobre as quais estão constituídas as próprias relações dentro da facção.

Em troca da garantia da manutenção de uma posição que lhe confere uma série de privilégios, a massa exige que o líder demonstre cumprir à risca as leis do grupo. Para Malinowski (2003), a representação do papel do líder, dada a sua posição de evidência e exemplo, exige do indivíduo maior cumprimento da lei.

${ }^{137}$ Edição Extra da revista Caros Amigos: PCC, 2006, p. 7.

${ }^{138} \mathrm{Na}$ mesa redonda no lançamento da Revista $\mathrm{n}^{\circ} 61$ de "Estudos Avançados”, realizada no Instituto de Estudos Avançados - Universidade de São Paulo, em 2007. 
Além do mais, a posição de liderança é instável e, no mundo do crime, um rearranjo de poder no grupo pode significar a morte de todos ligados às antigas lideranças. Segundo o relato de Souza (2007, p. 165), dos oito fundadores do PCC, sete já morreram, seis a mando da própria facção.

Uma boa liderança deve mostrar-se sempre segura e firme no seu comando, sob pena dos liderados questionarem seu poder; e suas ações devem estar em consonância com os interesses do grupo.

\subsection{Faç̧ões criminosas: um meio de afirmação identitária?}

"Mas é preciso reconhecer que, em meio a tantas dificuldades, o Fundão nos deu um mínimo de estabilidade, condição para que construíssemos uma identidade".

(Lima, 2001, p.63)

"Além dos fatos, há os valores: o respeito próprio, a lealdade para com os companheiros, a denúncia das incongruências da ordem penal no sentido da organização, a ação bem pensada. Segundo o autor a criação do Comando Vermelho representou, sobretudo uma mudança de atitude e de comportamento. Deixar de ser barata tonta e afirmar-se como sujeito, senhor de direitos e poderes, mesmo no interior das execráveis prisões brasileiras”.

(prefácio de Percival de Souza in Lima, 2001, p.15).

Uma das hipóteses iniciais desta pesquisa era que as facções criminosas poderiam constituir uma representação do ajustamento secundário perturbador descrito por Goffman (1974) ${ }^{139}$. Nesse sentido, a negação pelo indivíduo do papel que lhe é reservado pela instituição seria

${ }^{139}$ Os tipos de ajustamento descritos por Goffman foram objetos do Capítulo 3 desta Dissertação. 
uma forma de o indivíduo preservar sua individualidade e autonomia perante o sistema prisional.

Os ajustamentos secundários perturbadores corresponderiam ao que Silva (1998, p. 164) denominou mecanismos de resistência ao processo de institucionalização. Esses mecanismos representariam a antítese do conformismo, e estariam entre os "esforços para a preservação dos fatores que compõem a subjetividade do indivíduo”.

E, assim como os ajustamentos secundários perturbadores, os mecanismos de resistência atuariam na defesa dos valores que são próprios do individuo, podendo projetá-lo “em uma escalada ascendente da evolução e aperfeiçoamento de sua própria identidade” (Silva, 1998, p. 166).

Apesar das facções criminosas, em certo sentido, poderem ser consideradas uma forma de resistência à invasão institucional, elas não libertam o indivíduo, tampouco aperfeiçoam sua identidade. A organização a partir de mecanismos disciplinares e punições mais rígidas do que as do sistema de justiça impingem no indivíduo outro padrão identitário e prendem-no em outra subjetividade.

A inserção dos presos nessas facções faz com que sua identidade seja construída perversamente, já que o indivíduo sai do âmbito de proteção do Estado para ser conformado segundo os padrões da organização informal.

Zaluar (2004) atesta em que medida as organizações criminosas conformam um tipo especifico de masculinidade nos jovens envolvidos com o trafico de drogas no Rio de Janeiro. O processo de busca da identidade desses jovens passa pelo o que ela denominou etos guerreiro ou hipermasculinidade, ou seja, pela afirmação da figura masculina através do exercício de poder, demonstrado a partir da exibição de armas de fogo e pela capacidade de destruir o adversário (Zaluar, 2007, p. 2).

Em um sistema onde as relações sociais são mediadas pela violência, a figura do "homem macho” emerge enquanto potência, que atua e influencia a configuração social. A 
hipermasculinidade é afirmada a despeito de outras características e valores do individuo. A supremacia do "homem macho" sobre outras formas de subjetividade pode ser ilustrada pela fala de um suposto integrante de uma organização criminosa:

“-Você é o Serginho da Ivete? - perguntou à queima-roupa.

- Isso não tem importância. Eu não tenho nome. Não tenho nada pessoal pra contar.

- Vou mudar a pergunta: você é do Comando Vermelho?

- Sou um tipo de pessoa que não aceita sacanagem sem reagir. Na cadeia eu aprendi que um homem deve andar de cabeça erguida Se para isso for preciso lutar, eu luto."

(Amorim, 2006, p. 181)

Essa super-afirmação da identidade masculina se contrapõe ao sentimento de castração simbólica (Thompson, 2002) vivenciado pelo indivíduo preso. Esse sentimento decorre das exigências impostas pelo cárcere, tais como: o abandono coercitivo do papel do preso enquanto provedor de sua família; limitação sexual e das possibilidades de relacionar-se com o sexo oposto; impossibilidade de tomar decisões autonomamente.

Grande parte dos que pertencem às facções criminosas sofre um processo de massificação, no qual sua identidade e sua individualidade são afetadas. Dentro dos grupos, os interesses e características individuais normalmente não sobressaem. Os indivíduos estão juntos por um fim único e pelo sentimento compartilhado de exclusão. O que os distingue perde importância frente ao que os une.

Além do mais, a fala dos presos é a fala das facções. As facções mantêm o seu poder, e o monopólio sobre o saber do crime, a partir de práticas que fazem do preso um "objeto de informação, nunca sujeito numa comunicação" (Foucault, 2002, p. 177). 
Enquanto grande parte da massa carcerária continua vulnerável aos sistemas de poder (tanto aos formais quanto informais), seus líderes, ao ocuparem uma posição privilegiada, conseguem construir uma identidade diferenciada, que nega as exigências institucionais e se reafirma no exercício de poder sobre os que estão abaixo dele na hierarquia da facção.

O fortalecimento do indivíduo frente aos sistemas de controle e punição está ligado, entre outras coisas, à consciência política do preso. Quanto maior for seu entendimento acerca da constituição, das relações de poder dentro e fora da prisão, e da forma em que ele próprio se situa nesse arranjo, mais elaboradas são suas ações:

“... a gente aqui tem noção política, somos politizados. Então a gente sabe, em determinado momento, se se faz uma situação, por que está se fazendo(...). Que nem essa transferência do Nagashi. A gente sabia que ali era uma forma de ele dar uma resposta pra sociedade.”

(Marcola, CPI- Tráfico de Armas, 2006)

A partir dessa consciência, o preso não só pode compreender o sentido das decisões tomadas em âmbito prisional, mas consegue planejar suas ações tendo em vista sua repercussão no cárcere e na sociedade. A diminuição da vulnerabilidade do indivíduo passa pela elaboração de sua história e do aumento de sua capacidade reflexiva. Como fica claro em outro momento da fala de Marcola:

“A gente com a violência pode trazer violência pra gente também e fazer com a repercussão dessa violência se voltar contra a gente também”.

“Mas fui criado por determinadas pessoas, agindo de má-fé para ter um bode expiatório. E cada vez que as coisas dessem errado e eles não soubessem como controlar e a quem punir, tinha lá o Marcola. É muito fácil ter um cara igual a mim. Se eu fosse político, eu ia arrumar um Marcola também”. 
Geralmente, os líderes conseguem elaborar melhor seus conflitos e verbalizar as angústias comuns à massa carcerária. Suas falas vão ao encontro dos anseios e valores dos presos. A união do grupo é reforçada pela eleição do sistema de justiça criminal e das outras facções.

Nesse sentido, as lideranças conseguiriam de alguma forma solidificar a identidade, experimentar outras formas de subjetivação, ao passo que, para o preso comum, as faç̧ões consistiriam uma nova prisão, com exigências mais severas do que as institucionais.

Logo, as conseqüências na identidade de pertencer a uma facção criminosa são sentidas de forma diferente por aqueles que ocupam os papéis de líderes e pela massa carcerária. A diferença na afirmação identitária de um e de outro pode ser ilustrada pela fala de dois presos em um dos encontros do Grupo de Dialogo Universidade-Cárcere-Comunidade, cujo tema era as consequiências do processo de prisionização. Dentro desse contexto, quando um dos presos atesta "porque aqui a gente não é ninguém”, o outro preso (que ocupava a posição de liderança naquela penitenciária) reage prontamente - bate no peito e afirma: "Eu sou alguém”.

\section{6. A autonomia ética como condição da subjetividade}

Os sistemas de controle (não só o sistema prisional, mas o educacional, o familiar, o religioso, etc.) estabelecem padrões de normalidade, dentro dos quais a identidade tende a se fixar. A existência em sociedade é disciplinada por mecanismos de controle. São estabelecidos caminhos a trilhar e metas a alcançar, de modo que "nenhuma ovelha, fuja do rebanho" (Câmara, 2001, p.155).

O sujeito, para Foucault, é alguém preso à sua própria identidade pela ação do poder e do saber. Ele se constrói a partir de mecanismos de normalização, sempre atrelados a um saber que o justifica. O sujeito fruto da tecnologia disciplinar será regido pela norma, em oposição ao sujeito antigo que era regido pela ética, na relação consigo mesmo (Foucault, 2005). 
O processo de subjetivação reside justamente nos espaços de resistência a esse saber-poder: onde "indivíduos ou comunidades se constituem como sujeitos, à margem dos saberes constituídos e dos poderes estabelecidos” (Vicentim, 2005, p.316).

São nesses espaços que o indivíduo poderá relacionar-se eticamente, consigo mesmo, fazer escolhas e produzir sua própria subjetividade. A autonomia ética proporciona ao indivíduo a liberdade e a responsabilidade de se auto-determinar. É nesse sentido que Foucault afirma (1995, p.239) "Temos que promover novas formas de subjetividade através da recusa desse tipo de individualidade que nos foi imposto há vários séculos”.

As leis do cárcere agem em conjunto com os mecanismos disciplinares para conformar o tipo de individualidade a ser seguido. A ação tanto da ordem formal quanto da informal produz comportamentos que prendem o indivíduo na normalidade e o tornam ainda mais vulnerável.

A prisão conforma o preso dentro de basicamente dois padrões de identidade: institucional ou delinqüente. A identidade institucional é fruto da ação dos mecanismos disciplinares e da ordem formal sobre o indivíduo. As organizações informais funcionam muitas vezes como mecanismos de resistência à internalização da identidade institucional. Apesar disso, elas não dão ao indivíduo autonomia ética - ao contrário: através da severidade das suas leis e punições, e da ação de seus próprios mecanismos disciplinares, elas prendem os indivíduos em outra forma de identidade: na identidade delinqüente.

Segundo Sá (2007, p.11), a retomada pelo preso de sua identidade só é possível a partir de estratégias que facilitem a ele retomar o pensamento e a simbolização. É a partir da elaboração de sua história e da apropriação das suas escolhas que os presos podem se colocar enquanto indivíduos autônomos, “donos de seus próprios atos”. O fortalecimento psíquico do indivíduo é condição para que ele resista aos tipos de individualidade que a organização formal e informal quer produzir, e construa uma subjetividade autônoma: 
"Ao rever a sua própria carreira moral, o estigmatizado pode escolher e elaborar retrospectivamente as experiências que lhe permitem explicar a origem das crenças e práticas que ele adota em relação a seus iguais e aos normais".

(Goffman, 1988, p.48) 


\section{NOTAS CONCLUSIVAS}

Há muito tempo vem se estudando o impacto da instituição prisional sobre a identidade do preso e sua eficácia em atender as finalidades a que se propôs. A conclusão dessas análises, em sua grande maioria, converge no sentido do fracasso da prisão enquanto meio de reinserir o indivíduo na sociedade.

A ação reiterada dos processos de criminalização e institucionalização sobre a identidade do indivíduo acentua sua vulnerabilidade psico-social. A internalização da cultura prisional e a ação dos mecanismos de controle reforçam as características que levaram o indivíduo a ser selecionado pelo sistema de justiça criminal, aprisionando-o no ciclo da desviação.

A inserção do indivíduo no sistema prisional reforça a representação de papéis sociais que conformarão formas especificas de subjetivação. Ao indivíduo preso é reservada a manifestação de, basicamente, dois tipos de identidade: a institucional e a delinqüente; ambas caracterizadas pela situação de exclusão do indivíduo do meio social mais amplo.

Contudo, o modo como a instituição prisional irá agir sobre o indivíduo não é fixo. A função a ser exercida pela pena privativa de liberdade está diretamente relacionada com a racionalidade penal e com as escolhas no âmbito de política criminal e penitenciária de determinado momento histórico.

O discurso ressocializador, que se afirmou no Brasil a partir dos anos oitenta, vem sendo aos poucos substituído pela legitimação da prisão enquanto controle puro. Se antes a prisão pretendia reformar o indivíduo para readequá-lo aos padrões sociais, hoje esse objetivo tem sido sacrificado em nome da segurança e do controle. O cárcere passa a se legitimar unicamente enquanto mecanismo de exclusão, cuja função não é mais produzir uma identidade, mas anular a existência do indivíduo.

Ao mesmo tempo em que essa nova forma de exercício do poder incrementa os níveis de encarceramento e exclui parcelas indesejáveis da população, ela flexibiliza as formas de 
sujeição do indivíduo ao poder, ampliando seu alcance para além das instituições totais. O controle, que vinha sendo feito de forma concentrada nos espaços institucionais e direcionado a alguns indivíduos, expande-se para o exterior dessas instituições e alcança a população como um todo, indiscriminadamente. Configurando, dessa forma, a substituição da sociedade disciplinar pela sociedade de controle.

A ordem formal da prisão (constituída pelas normas produzidas pelo Estado), somada aos mecanismos que visam à manutenção da disciplina do cárcere, vulnerabilizam o indivíduo e o desabilitam , criando muitas vezes estratégias que o prendem na identidade institucional.

$\mathrm{Na}$ tentativa de se desprender da identidade institucionalizada, os presos criarão meios de afirmação de outra forma de subjetividade. Para preservar os valores que lhe são próprios, os presos, muitas vezes, rompem com os valores institucionais.

Uma das estratégias dos indivíduos para lidar com as exigências institucionais é agregar-se em torno de organizações informais. Esses grupos informais, representados por seus líderes, podem de certa forma, serem considerados mecanismos de resistência coletivos, pelos quais o indivíduo tenta escapar do papel social que o sistema lhe reserva.

A condição de excluído compartilhada pelos indivíduos presos contribui para a coesão das organizações instituídas dentro da prisão. O sentimento de pertencimento ao grupo, contrastado com o sentimento de despertencimento à sociedade mais ampla, encoraja o indivíduo a desafiar o sistema de controle. Respaldado pelo apoio e pela força do grupo, o indivíduo passa a tomar atitudes de enfrentamento que dificilmente teriam efeito se realizadas no âmbito individual.

Porém, a coesão dos indivíduos em torno de organizações informais contribui para a internalização da cultura prisional e dos valores desses grupos. Longe de contribuir para a produção e expressão da individualidade do indivíduo preso, o aprisiona em outro tipo de identidade, a chamada identidade delinqüente. 
Uma das hipóteses iniciais desta pesquisa era que as facções enquanto mecanismos de resistência constituiriam em uma forma do individuo preservar a identidade. Mas, apesar das facções contribuírem para afirmação da identidade desvinculada da institucional, a inserção dos presos nessas organizações faz com que sua identidade seja construída perversamente.

Dessa forma, a consolidação das organizações criminosas no sistema prisional não pode ser interpretada como mecanismo de resistência. Apesar de representarem a antítese do conformismo e libertarem o individuo de alguns padrões institucionais, as facções o apreendem no seu próprio controle. O pertencimento do indivíduo a uma dessas organizações não leva ao seu fortalecimento e não faz dele um ser mais livre, portador de uma subjetividade própria.

Partindo da visão de Foucault, o pressuposto para a construção de uma subjetividade seria a construção de uma ética autônoma aos mecanismos de controle. Somente com a recusa da individualidade que lhe é imposta pelo poder é que a pessoa pode se auto-determinar. A construção de uma forma livre de subjetivação se contrapõe à sujeição. Ela ocorre à margem dos saberes constituídos e dos poderes estabelecidos, a partir da educação exercida de si por si mesmo.

Mudar a forma de pensar a punição é o primeiro passo para a construção de uma sociedade mais equilibrada. Nesse sentido, a escolha por interpretar as situações problemáticas e as condutas desviantes dentro de uma perspectiva inclusiva e não punitivista faz dos indivíduos pessoas mais livres e responsáveis. E, ainda, permitir ao indivíduo preso fazer escolhas e assumir responsabilidades pautadas na ética interiorizada pela relação dele consigo mesmo pode-se restituir-lhe a capacidade de estabelecer laços com a sociedade e fortalecer a sua identidade. 


\section{BIBLIOGRAFIA}

ADORNO, Sérgio (1993). Sistema penitenciário no Brasil. Problemas e desafios. Revista do Conselho Nacional de Política Criminal e Penitenciária, São Paulo, v. 1, n. 2, p. 63-87.

e SALLA, Fernando (2007). Criminalidade organizada nas prisões e os ataques

do PCC. Estudos Avançados, v. 61, p. 7-29, 2007.

AMORIM, Carlos (2006). CV-PCC: a irmandade do crime. Rio de Janeiro, Record.

ANDRADE, Vera Regina Pereira de (1996). Do paradigma etiológico ao paradigma da reação social : mudança e permanência de paradigmas criminológicos na ciência e no senso comum. Revista Brasileira de Ciências Criminais, São Paulo, n. 14, p. 276-287.

ALVAREZ, Marcos César (2003). Bacharéis, criminologistas e juristas: saber jurídico e nova escola penal no Brasil. São Paulo, IBCCRIM.

BARATTA, Alessandro (1981). Conflit social et criminalite. Pour la critique de la theorie du conflit em criminologie. Déviance et Société, vol. 6, n. 1, p. 1-22.

Direito Penal. Rio de Janeiro, Revan.

(2002). Criminologia crítica e crítica do direito penal. Introdução à Sociologia do

BARCELLOS, Caco (2003). Abusado - o dono do morro Dona Marta. Rio de Janeiro, Record.

BAUMANN, Zygmunt (2000). Social uses of law and order, in GARLAND, David, SAPARKS, Richard Criminology and social theory. New York, Oxford University Press.

BECK, Ulrich (2002). La sociedad del riesgo: hacia una nueva modernidad. Barcelona, Paidós.

BECKER, Howard (1971). Los extraños. Sociología de la desviación. Buenos Aires, Tiempo Contemporáneo.

BIONDI, Karina (2006). Tecendo as tramas do significado: as facções prisionais enquanto organizações fundantes de padrões sociais in "Antropologia e Direitos Humanos", Prêmio ABA/FORD Direitos Humanos categoria graduação, mimeo.

CALDEIRA, Cesar (2004). A política do cárcere duro: Bangu 1. In São Paulo em Perspectiva, vol.18, n. 1.

(2005). Presídio sem facção criminosa no Rio de Janeiro? Estudo sobre

o experimento ocorrido no presídio Hélio Gomes. Rio de Janeiro: mimeo.

CÂMARA, Heleusa Figueira (2001). Além dos muros e das grades (discursos prisionais). São Paulo: EDUC.

CARVALHO, Salo de (2007). Da necessidade de efetivação do Sistema Acusatório no Processo de Execução Penal in CARVALHO, Salo de (org) Crítica à Execução Penal. Rio de Janeiro, Lumen Juris, pp. 417-428. 
CARVALHO, Salo de e FREIRE, Christiane (2007). O Regime Disciplinar Diferenciado: notas críticas à reforma do sistema punitivo brasileiro. in CARVALHO, Salo de (org) Crítica à Execução Penal. Rio de Janeiro, Lumen Juris, pp. 269-283.

CASTRO, Lola Aniyar de (2005). Criminologia da libertação. Rio de Janeiro: Revan. (1983). Criminologia da reação social. Rio de Janeiro: Forense.

CASTRO, Myriam Mesquita P. de (1991). Ciranda do Medo. Revista USP, São Paulo, n. 9, pp. 57-64.

CLEMMER, Donald (1958). The prison community. New York: Rinehart \& Comapany. CHAMBLISS, William (1980). A economia política do crime: um estudo comparativo da Nigéria e dos Estados Unidos in TAYLOR, WALTON, YOUNG. Criminologia crítica, Rio de Janeiro: Graal, 1980.

CHARRIÈRE, Henri (1980). Papillon: O homem que fugiu do inferno. Rio de Janeiro: Difel.

CHIES, Luiz Antônio Bogo (2004) Resenha. As prisões em São Paulo: 1822-1940. SALLA, Fernando. Sociologias, vol., n. 11.

CIAMPA, Antônio da Costa (2005). A estória do Severino e a História da Severina. São Paulo: Brasiliense.

(2004). Identidade. In: W. Codo \& S. T. M Lane (Orgs.). Psicologia social: o homem em movimento (pp. 58-75), São Paulo: Brasiliense.

CODO, Wanderlay e LANE, Silvia T. M (orgs.) (2004). Psicologia Social: o homem em movimento. São Paulo: Brasiliense.

COHEN, Albert (1968). Transgressão e controle. São Paulo: Livraria Pioneira Editora.

COHEN, Claúdio e AUGUSTINIS, Emílio (1998). É possível a autonomia do sentenciado no Sistema Penitenciário? Bioética, 1998, nº 6, pp. 55-59.

CHRITIE, Nils (1999). Elementos para uma geografia penal. Revista de Sociologia e Política, $\mathrm{n}^{\circ} 13$ : 51-57, novembro.

COMISSÃO TEOTÔNIO VILELA- CTV (1984). Relatório de visita da Comissão Teotônio Vilela à Penitenciária do Estado.

CUNHA, Antônio Geraldo da (2007). Dicionário etimológico da língua portuguesa. Rio de Janeiro: Lexikon Editora Digital.

DAZA, Abrahan Pérez (2001). El Derecho Penal ante la Globalización. Instituto de Ciencias Jurídicas de Egresados de la UNAM, Campus Aragón A.C. 
DEBUYST, Christian (2001). La psychologie criminelle face aux défis qui lui sont poses. Sub Judice: justiça e sociedade, Coimbra, n 22/23, p. 7-13.

vol XXV, n.2, p. 49-72.

(1992). Les paradigmes du droit pénal et les criminologies cliniques. Criminologie,

(1989). Perspectives cliniques en criminologie : le choix d'une orientation. Eguzkilore - Cuaderno del Instituto Vasco de Criminología, n. 2, p. 251-265.

(1995). Qui récupère qui?. Déviance et Société, vol. 19, n. 3, p. 257-265.

DELEUZE, Gillles (1992). Conversações. São Paulo, Editora 34.

DIAS, J. F. \& ANDRADE, M. da C. (1997). Criminologia: o homem delinqüente e a sociedade criminógena. Coimbra: Editora Coimbra.

EPSTEIN, Isaac (1990). Subsídios para uma gramática do poder. São Paulo, Tese (Doutorado) Escola de Comunicação e Artes, Universidade de São Paulo.

FERREIRA , Gerson André Albuquerque (2003). A jaula de ferro e a casa dos loucos: sobre a normalização da ação institucional na constituição do asilo psiquiátrico e no sistema carcerário na constituição do individuo patológico e delinqüente. In Revistas dos Pós-graduandos em Sociologia UFPB Par'a'iwa, http://www.cchla.ufpb.br/paraiwa/04-gerson.html, acesso 18/12/07.

FISHER, Rosa Maria (1989). Poder e Cultura em Organizações Penitenciárias. São Paulo, Tese (Livre-docência) - Faculdade de Economia e Administração, Universidade de São Paulo, mimeo.

FONSECA, Márcio Alves (2003). Michel Foucault e a constituição do sujeito. São Paulo: EDUC.

FOUCAULT, Michel (2003). A verdade e as formas jurídicas. Rio de Janeiro: Nau.

(1996). A ordem do discurso. São Paulo: Edições Loyola.

(2002-A). A palavra e as coisas. São Paulo: Martins Fontes.

(2006). Estratégia, poder-saber. Rio de Janeiro: Forense Universitária.

(2005). Historia da sexualidade I: A vontade de saber. Rio de Janeiro, Edições

Graal, 2005.

(2004). Microfísica do poder. Rio de Janeiro: Graal.

(1995). Sujeito e o poder. In: Rabinow, Paul e Dreyfus, Hubert. Michel Foucault, Uma trajetória filosófica: Para além do estruturalismo e da hermenêutica. Rio de Janeiro: Forense Universitária.

Vozes.

(2002). Vigiar e Punir. História da violência nas prisões. Petrópolis:

FRANCO, Alberto Silva (2003). Meia ilegalidade: Regime Disciplinar Diferenciado. São Paulo: Boletim IBCCRIM, , v.ll, n.l23, p.2-3, fev., 2003. 
FREUD, Sigmund (1943). Psicologia de las masas y analisis del yo. Buenos Aires: Editorial Americana Chacabuco.

GARLAND, David (1999). As contradições da sociedade punitiva: __ _ (1999), As contradições da 'sociedade punitiva': o caso britânico. Revista de Sociologia e Política, 13: 59-80, nov., Curitiba.

GÓES, Eda Maria (2004). Transição política e cotidiano penitenciário. História, São Paulo, vol.23, n. 1-2.

GOFFMAN, Erving (1985). A representação do eu na vida cotidiana. Petrópolis: Vozes.

(1988). Estigma. Rio de Janeiro: LTC.

(1974). Manicômios, prisões e conventos. São Paulo: Perspectiva.

GOMES, Luis Flávio e CERVINI, Raul (1997). Crime Organizado: enfoques criminológico, jurídico (Lei 9034/95) e político criminal. São Paulo: Ed. Revista dos Tribunais.

HASSEMER, Winfried (1999). Persona, mundo y responsabilidad. Valencia: Tirant lo Blanch.

HOUAISS (2001). Dicionário Houaiss da língua portuguesa. Rio de Janeiro: Objetiva.

HULSMAN, Louk (2004). Alternativas à justiça criminal in PASSETTI, Edson (org.) Curso Livre de Abolicionismo Penal. Rio de Janeiro: Revan.

(1985). La perspectiva abolicionista in Revista del Instituto de Ciencias Penales y Criminologia. Bogotá ,Universidad Externado Colombia, vol. VIII, nº 25.

ILANUD. Incidentes Prisionais: Principais Características e Formas de Evitá-los. Revista do ILANUD. São Paulo, n. 09, 1998, pp. 16-39.

JAKOBS, Gunter e MELIÁ, Cancio (2003). Derecho penal del enemigo. Madrid: Cuadernos Civitas.

JOCENIR (2001). Diário de um detento: o livro. São Paulo: Labortexto Editorial.

KAFKA, Franz (1995). Diante da Lei In O Processo. São Paulo: Brasiliense.

(1996). Na colônia penal. Rio de Janeiro: Paz e Terra.

KUNH, Thomas S (2005). A estrutura das revoluções científicas. São Paulo: Perspectiva.

LARRAURI, Elena (2000). La herancia de la criminología crítica. Madrid: Siglo Vinteuno de Espana Editores.

LIMA, William da Silva (2001). Quatrocentos contra um: uma historia do Comando Vermelho. São Paulo: Labortexto Editorial.

LINO, Wagner (1996). Relatório final da Comissão Parlamentar de Inquérito sobre os Estabelecimentos Prisionais do Estado de São Paulo, mimeo. 
LISPECTOR, Clarice (1998). A hora da estrela. São Paulo: Rocco.

MACHADO, Marta Rodriguez de Assis (2005). Sociedade de risco e Direito Penal: uma avaliação das novas tendências políticos-criminais. São Paulo, IBCCRIM.

MAHEIRIE, Kátia (2002). Constituição do sujeito, subjetividade e identidade in Interacões, jan-jul, ano/vol VII, número 13, Universidade São Marcos, São Paulo.

MALINOWSKI, Bronislaw (2003). Crime e costume na sociedade selvagem. Brasília: Ed. Universidade de Brasília, São Paulo: Imprensa oficial.

MARQUES, José Benedicto de Azevedo (1997), Gerenciamento de crises no sistema prisional, Revista do Ilanud no 5. São Paulo, pp. 1-20.

MARTEAU, Juan Félix (1997). A condição estratégica das normas: sobre as possibilidades teóricoepistemológicas da crítica criminológica radical às práticas penais. São Paulo: IBCCRIM.

MARTINS, Sérgio Mazina (2004). Problemas dos sistemas penitenciários brasileiros em face das redes e organizações criminosas. Direito e Cidadania, Cabo Verde, ano VI, maio/dez 2004, p. 39-62. MEAD, George H (1953). Espiritu, persona y sociedad. Buenos Aires: Editorial Paidos.

MERTON, Robert K (1957). Social theory and social structure. Glencoe: The Free Press.

MILLS, Theodore M (1970). Sociologia dos pequenos grupos. São Paulo: Pioneira.

MINGARDI, Guaracy. O Estado e o crime organizado. São Paulo, IBCCRIM, 1998.

(2007). O trabalho da Inteligência no controle do crime organizaco in Estudos Avançados, v. 21, p. 51-69.

MISSE, Michel (2007). Mercados ilegais, redes de proteção e organização local do crime no Rio de Janeiro. Estudos Avançados, v. 21, p. 139-157.

MORAES, Pedro Rodolfo Bode de (2005). Punição, encarceramento e construção de identidade profissional entre agentes penitenciários. São Paulo: IBCCRIM.

MOURA, João Clemente Quaresma de (2007). O poder na obra de Foucault e as estratégias do contemporâneo. Dissertação (Mestrado em Psicologia) - Pontifícia Universidade Católica do Rio de Janeiro, Rio de Janeiro.

MUCHAIL, Sangra Tannus (1985). O lugar das instituições na sociedade disciplinar in Recordar Foucault. São Paulo, Brasiliense.

PIAZON, Rafael (2006). A progressão de regime em crime hediondo disponível no endereço www.cdr.unc.br/cursos/Direito/Rafael.doc, acesso 06/12/2007.

PIMENTEL, Manuel Pedro (1983). O crime e a pena na atualidade. São Paulo, Editora Revista dos Tribunais. 
PIRES, Alvaro Penna (1992). Des signes d'un renouveau en Criminologie?. Criminologie, vol XXV, n.2, editorial, p. 3-11.

(1994). La criminalité: enjeux épistémologiques, theóriques et ethiques. Traité dês problèmes sociaux, Montreal: Institut québécois de reserche sur la culture, p.247-277.

(1993). La criminologie et ses objets paradoxaux : réflections épistémologiques sur un nouveau paradigma. Déviance et Société, vol. 17, n. 2, p. 129-161.

RAMALHO, José Ricardo (2002). O mundo do crime: a ordem pelo avesso. São Paulo: IBBCRIM.

RIOS, J. A. Motins em Prisões: seus Fatores e Possibilidades de Preveni-los. Revista do ILANUD. São Paulo, n. 09, 1998, pp. 1-15.

ROIG, Rodrigo Duque Estrada (2005). Direito e prática histórica da execução penal no Brasil. Rio de Janeiro: Revan.

RUSCHE, Georg; KIRCHHEIMER, Otto (2004). Punição e estrutura social. Rio de Janeiro: Editora Revan.

SÁ, Alvino Augusto de (2000). Algumas ponderações acerca da reintegração social dos condenados à pena privativa de liberdade. Revista da Esmape Recife, v. 5, n. 11, p. 25-70, jan./jun.

(2001). Concepção de crime como expressão de uma história de conflitos: implicações na reintegração social dos condenados à pena privativa de liberdade. Revista Esmesc (Escola Superior de Magistratura do Estado de Santa Catarina), ano 07, vol. 11, p. 169-178.

dos Tribunais.

(2007-A). Criminologia Clínica e Psicologia Criminal. São Paulo: Editora Revista mimeo.

(2007). Facções criminosas: uma análise à luz da psicologia das massas. São Paulo: (2007-B). Massa, crime organizado e facções criminosas. Revista Ciência Criminal, v. esp., p. 78-83, 2007.

(2005). Sugestão de um esboço de bases conceituais para um sistema penitenciário. Manual de projetos de reintegração social. Secretaria de Administração Penitenciária / Departamento de Reintegração Social do Estado de São Paulo, p. 13-21.

(1998). Prisionização: um dilema para o cárcere e um desafio a comunidade. Revista Brasileira de Ciências Criminais São Paulo, v. 6, n.21, p. 117-123, jan./mar.

SALLA, Fernando (1999). As prisões em São Paulo -1822 - 1940. São Paulo, Ed. Annablume / Fapesp. (2006). As rebeliões nas prisões: novos significados a partir da experiência brasileira. Sociologias, Porto Alegre, ano 8, n. 16, jul/dez 2006, p. 274-307. 
(1997). Breves notas para a história do encarceramento em São Paulo : a penitenciária do Estado. Revista Brasileira de Ciências Criminais, ano 5, n.20, out/dez 1997, p. 293302.

(2000). Casa de Detenção de São Paulo: passado e presente. Revista Brasileira de Ciências Criminais, ano 8, out/dez 2000, p. 213-220.

(2003). Novos e velhos desafios para as políticas de segurança pública no Brasil. Revista Brasileira de Ciências Criminais, ano 11, abril/junho 2003, p. 349-361.

SANTOS, Boaventura de Souza (1999). Pela mão de Alice: o social e o patológico na pós modernidade. São Paulo: Cortez.

SANTOS, Rosicler (2007). Alguns aspectos destacados das obras de Foucault no que se refere ao Direito: poder, soberania $\quad$ e disciplina. Disponível http://www.uj.com.br/publicacoes/doutrinas/default.asp?action=doutrina\&iddoutrina=4671, acesso 20/12/2007.

SCHMIDT, Andrei (2007). A crise da legalidade na Execução Penal in CARVALHO, Salo de (org) Crítica à Execução Penal. Rio de Janeiro, Lumen Juris, pp. 29-76.

SHECAIRA, Sérgio Salomão (2004). Criminologia. São Paulo: Ed. Revista dos Tribunais.

SILVA, Luiz Antonio Machado da (2004). Sociabilidade violenta: por uma interpretação da criminalidade contemporânea no Brasil urbano. Soc. estado., jan./jun., vol.19, no.1, p.53-84.

SILVA, Roberto da (1998). Os filhos do governo. São Paulo: Ática.

SOUZA, Percival de (1983). O Prisioneiro da Grade de Ferro. São Paulo: Editora Traço. (2006). Sindicato do crime. São Paulo: Ediouro.

SPINK, Mary Jane (org.) (1999). Práticas discursivas e produção dos sentidos no cotidiano: aproximações teóricas e metodológicas. São Paulo: Cortez.

STRAUSS, Anselm L. (1999). Espelhos e máscaras: a busca de identidade. São Paulo: EDUSP.

SYKES, Gresham (2007). The society of captives: a study of a maximum security prison. Princeton: Princeton University Press.

TALLI, Renato Laércio (2001). A sombra do medo: degeneração humana. São Paulo: Juarez de Oliveira.

TAYLOR, WALTON, YOUNG (1980). Criminologia crítica. Rio de Janeiro: Graal. 
TEIXEIRA, Alessandra (2006). Do sujeito de direito ao estado de exceção: o percurso contemporâneo do sistema penitenciário brasileiro. Dissertação de mestrado em Sociologia, São Paulo, FFLCH/USP, mimeo.

TELLES, Vera da Silva; HIRATA, Daniel (2007). Cidade e práticas urbanas: nas fronteiras incertas entre o ilegal, o informal e o ilícito. Estudos Avançados, v. 61, p. 173-192.

THOMPSOM, Augusto (1998). Quem são os criminosos? Rio de Janeiro: Lumen Juris.

(2002). A questão penitenciária. Rio de Janeiro, Ed. Forense.

VARELLA, Drauzio (1999). Estação Carandiru. São Paulo, Companhia das Letras.

VELO, Joe Tennyson (1998). Criminologia analítica: conceitos de psicologia analítica para uma hipótese etiológica em criminologia. São Paulo: IBCCRIM.

VICENTIN, Maria Cristina Gonçalves (2005). A vida em rebelião: jovens em conflito com a lei. São Paulo, Hucitec/Fapesp.

VIOLANTE, Maria Lúcia (1982). O dilema do decente malandro. São Paulo: Cortez.

WOLA (2006). Youth gangs in central America. Washington: Wola Special Report, nov/2006.

ZAFFARONI, Eugenio Raúl (1990). A criminologia como instrumento de intervenção na realidade. In Revista da Escola do Serviço Penitenciário, Porto Alegre: ano 1, n. 4 , setembro/1990.

(1996). "Crime organizado": uma categorização frustrada. In: Discursos

Sediciosos- crime, direito e sociedade, Rio de Janeiro, Relume-Dumará, pp. 45-67.

Temis.

(1998). Criminologia: aproximación desde un margen. Santa Fé de Bogotá: Ed.

(1991). Em busca das penas perdidas. Rio de Janeiro: Revan.

ZALUAR, Alba (2004). Integração perversa: pobreza e tráfico de drogas. Rio de Janeiro: FGV.

(2007). Os paradoxos da democratização do Brasil. In E premissas Revista de Estudos Estratégicos, $\mathrm{n}^{\circ}$ 2, jan/jun 2007. 